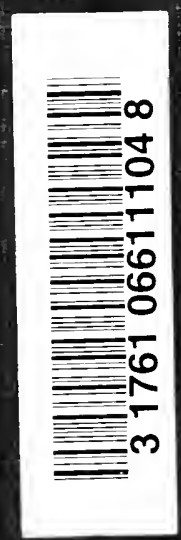




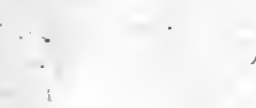



\section{THE SPEAKER OF THE HOUSE OF REPRESENTATIVES}


Digitized by the Internet Archive in 2007 with funding from Microsoft Corporation 


\title{
THE SPEAKER
}

OF THE

\section{HOUSE OF REPRESENTATIVES}

\author{
M. P. FOLLETT
}

WITH AN IN'TRODUCTION

BY ALBERT BUSHNELI, HART, PH.D.

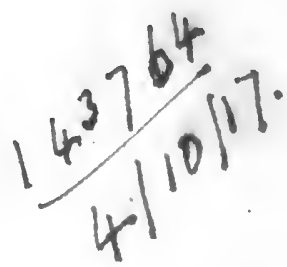

LONGMANS, GREEN, AND CO.

91 AND 93 FIFTH AVENUE, NEW YORK

LONDON, BOMBAY AND CALCUTTA 
Copyright, 1896, BY

LONGMANS, GREEN, AND CO.

First Fidition, MAY, 1896

REPRINTED, MARCH, IGOZ

REPRINTED, OCt, 1904

REPKINTED, SEPTEMBER, 1909 
T. $\mathfrak{X}$. 



\section{AUTHOR'S PREFACE.}

THE power of the Speaker of the House of Representatives, unknown to political theory, is the central feature of our actual system of government. The object of the following work is to show the growth of the Speaker's power from I 789 up to the present time. A necessary preliminary has been an examination of the precedents of the office, which exist chiefly in the practice of the House of Commons and of the colonial assemblies. A careful study either of the Speakership of the House of Commons or of the colonial Speakership would constitute an independent work in itself : I have attempted, therefore, to give only a general outline of these two precedents. Cobbett's and Hansard's "Debates" afford material for a study of the Speakership of the House of Commons, but in the case of the colonies there is little besides the meagre records of assemblies; the ground has as yet hardly been broken for a study of colonial political institutions.

The chief source for any work upon the Speaker of the House of Representatives is the congressional records. The records may be supplemented by books upon parliamentary law, memoirs, correspondence, biographies, and the register of public opinion as expressed in the newspapers, magazines, 
and other current literature. Among newspapers the Nation has been especially serviceable. In an appendix below will be found a bibliography of the Speakership. The future student of this subject will share my gratitude for the admirable indices to the later Journals and for the lists of the rules of the House and of questions of order decided, which are often, although not always, appended to them. Smith's "Digest of the Rules" and May's and Cushing's works on "Parliamentary Practice" are valuable helps in the study of any parliamentary question.

For a just appreciation of an office depending so much upon unwritten practice, this work should have been the labor of some member of the House of Representatives, long experienced in public life. Since none such has come forward, I have ventured the task, and have tried by patient study of the records and by inquiry from men in public life at least to prepare the way for a proper study of the Speaker.

I wish to thank the authorities of the Harvard College Library for the unrestricted use of their great collections. My thanks are also due the assistants of the Harvard Library, of the Boston Public Library, of the Massachusetts State Library, and of the Boston Athenæum, for their ready and thoughtful aid. To the ex-Speakers and members of Congress who have given me most helpful information on the actual workings of the Speakership, I am greatly indebted. To Miss Anna Boynton Thompson of the Thayer Academy, I owe 
very warm thanks for a careful reading of the proofsheets.

To Professor Hart, under whose direction this work has been prepared in the Radcliffe College Seminary of American History and Institutions, I am under the deepest obligation for advice, for valuable criticism, and for constant interest; without his continued help and without the stimulus of frequent discussion with him, this study would never have been completed. Professor Hart has read both manuscript and proof-sheets, and the book owes its present form largely to his suggestions.

To Radcliffe College, which in connection with Harvard College makes such work possible, its students welcome every opportunity to express a gratitude which only grows deeper as the years bring to them a keener appreciation of their great debt for very unusual privileges.

M. P. FOLLETT.

Quincy, October I, 1895. 



\section{INTRODUCTION.}

THAT it should still be possible in the year 1896

1 to publish the first elaborate and thorough study of the Speaker of the House of Representatives is a proof that such a work as this is needed. No one who looks below the surface of our national political system can fail to see that the Speaker is, next to the President, the most powerful man in the nation, and that his influence increases. Why has not some publicist or statesman long since made the Speakership his study? Clearly to describe this office, and to show its tendencies, would be no easy task even for one who understands the ins and outs of legislation, who catches at once the significance of a rule or resolution or decision, who has been intimate with successive Speakers.

Perhaps the subject has been neglected because public men do not stop to consider the real source of the familiar power of the Speaker. The ordinary books on public law pass him over, because he is hardly mentioned in the Constitution, his functions not being defined by that instrument, nor by statutes, nor even by rules, but by the growth of unwritten practice. While to the general public the personality of the Speaker is always interesting, the Speakership, as a powerful office, is less 
regarded. As compared with the presidency, it is less in the public eye: the choice of a Speaker usually occupies but a few days; that of the President congests the country for half a year. The Speaker's influence is silent: he has not, like the President, the right to withhold his signature from a bill duly passed; he sends no public message to announce his policy; his patronage is small; he is almost excluded from any part in military or diplomatic affairs; he is on duty only about twelve months in the course of two successive years. He has so little of the attributes of power which attract notice and give a man fame, that even so able and complete a critic as Mr. Bryce does not clearly bring out his real status.

Another reason why there has hitherto been no study of the Speaker, founded on investigation, is the volume and variety of the sources which have needed to be examined. The records of his activity are buried in the interminable reports of debates, or are diffused among letters and reminiscences. Till now the historical background for an intelligent comparison of the Speaker of the House with the English Speaker and the early presiding officer of Congress has been lacking. To study the historical growth of the Speaker's office, and to show from the actual practice of Congress what his functions have been and now are, has been the long and patient task of Miss Follett ; and the results speak for themselves. This book represents the strenuous labor of a well-equipped investigator for more than half of each year during four successive years. What- 
ever may be done by diligent search into the records, by visits to Washington, by conferences with exSpeakers, and by a comparison of all her varied material, has been done by the author. The work is not open to the charge of superficiality, nor of neglect of any important body of material available to students.

For the statements of fact the author is solely responsible. Miss Follett has made her own discoveries, arranged her own material, and expressed her own results in her own words, subject only to criticism and suggestion. Her instances and illustrations have been drawn from many obscure and neglected sources, and they have the weight of carefully selected original material; and more than ordinary pains have been taken to avoid errors.

Upon this basis of carefully ascertained fact the author has based her deductions, which are also her own. She has started out with no thesis to prove, and has had no political bias to overcome. Miss Follett appears to have worked in an impartial and scientific spirit to solve a knotty problem in history and practical government. She has accepted the individual Speakers as factors in the development of their office; but her conviction is that the office has sprung out of the necessities of the case, and has carried its holders with it.

The table of contents sufficiently indicates the arrangement of the work, but it does not point out the results gained from hitherto unworked material; nor the new views based on a comparison of what have till now seemed unrelated events. The book 
is really divided into five parts. First comes the preliminary historical sketch in Chapter $i$. In the brief discussion of the much neglected Colonial Speakership the author has established the important point that that office was political. Much light is also thrown on the political status of the President of the early Congresses, and the influence of that position on the minds of the members of the Constitutional Convention.

The second part of the work (Chapters ii. and iii.) deals with the present status of the Speakership. The materials have long been at hand for a critical view of the methods by which the Speaker is chosen; but Miss Follett appears to be the first to study these elections together, and to show how far new principles have come into the choice of Speaker. Without attempting any biographies of the Speakers, Miss Follett has, in Chapter iii., distinctly placed in relief the period of their Speakership. To the general reader this is one of the most interesting parts of the work, because of the little known details, taken from contemporaries, of the activity of such men as Banks, Colfax, Blaine, and Randall, and especially of Clay, whose qualities of brilliant and creative leadership have much attracted the author.

To the man of affairs and the student, the third part of the work-that on the functions of the Speaker (Chapters iv. to ix.) -will be especially important. Beginning with the ordinary moderator's powers of presiding and maintaining order, the analysis leads up through an interesting account of 
the Speaker's vote to the three nominally parliamentary powers which have become the foundations of a mighty political authority. Perhaps the greatest service of the author is to describe and discuss those three powers-acting against filibustering, appointing committees, and recognizing members. It is not the author's point of view to quarrel with the truth that through the partial and sometimes partisan use of these three prerogatives the Speaker has acquired his immense power to push legislation, and an absolute veto on all measures which may be introduced into the House. She accepts that situation as a geologist accepts a glacier: as a present, ungainsayable, moving, and resistless fact, not to be got rid of by asserting that it is not there. In the course of the discussion the author seems to establish that though, historically considered, filibustering is comparatively a modern evil, it is one which must be checked by the Speaker, or Congress will be impotent; that the committees have for more than half a century been political, and that there is no visible means of making them otherwise; and that the present "steering committee," in which the Speaker is the motive force, is a necessary guide to the deliberations of the House. On the more recent and rigid unwritten law that a member can speak only by the consent of the Speaker, the author takes neutral ground, and avers that "the subject is one of the most difficult to adjust in the whole legislative system."

The fourth part of the work is the summary, in the last two chapters, of the political status of the 
Speaker: the author's conclusions, very clearly expressed, are that the Speaker's power is necessary and salutary; that he was never intended to be a moderator, but from the beginning had and exercised political leadership; that he is the only visible means of escape from a legislative chaos; and that it is to the interest of good government that the Speaker exercise the responsibility which has gradually come upon him.

Though these conclusions are distinctly opposed to the teachings of many writers, they are evidently not put forward for the sake of contradicting others, but simply to state generalizations which seem to the author's mind best to interpret the mass of facts. The author is compelled to her belief by her own collection and analysis of the evidence. That evidence is voluminous, carefully sifted, and lies before the reader, or is made accessible by generous footnotes. I am convinced by it that the Speaker's present status is a natural, normal, and inevitable development of our system of government, and promises good and not evil. But the author would be the last to protest at any candid attempt to controvert her evidence or to gainsay her conclusions. For the purpose of this book is not to sustain a thesis, but to lead to the discovery of the truth.

\section{ALBERT BUSHNELL HART.}

HARVARD UNIVERSITY,

January I, 1896. 


\section{CONTENTS.}

\section{CHAPTER I.}

GENESIS OF THE SPEAKER'S POWER.

8 I. Importance of parliamentary law . . . . . . I

8. Appearance of a Speaker in the House of Commons. 3

8 3. The Speaker under the Tudors . . . . 3

8. Status of the Speaker under the Stuarts . 7

85. The Speaker in the eighteenth century . . I r

86. The Speaker in the Colonies . . . . . . . 12

8 7. Choice of Colonial Speaker . . . . . . 12

88. Parliamentary duties of Colonial Speakers . 14

89. The Colonial Speakers as political leaders . 15

\& 1o. The Speaker as head of the Opposition . . 18

\& Ir. Responsibility of Colonial Speakers . . . 19

8 12. The President of the Continental Congresses and of the Congress of the Confederation . . . $2 \mathrm{r}$

8 13. Powers of the President of Congress . . . $2 \mathbf{r}$ 8 14. The President of the Constitutional Convention. . 24 8 15. The Speakership clause in the Constitution . . 25

\section{CHAPTER II.}

CHOICE OF THE SPEAKER.

8 16. Importance of the subject . . . . . . . . . 27

8 17. Precedents.-Form of election in the House of Commons . . . . . . . . . . . . . 27 
8 18. English precedent of a party Speaker . . 29

8 19. Colonial practice. . . . . . . . . 30

8 20. Free choice by the House of Representatives . . 31

8. 21. Principles of choice . . . . . . . . . . . 33

8 22. Knowledge of parliamentary procedure . . 33

823. Previous service as Speaker . . . . . 34

824. Sectional claims . . . . . . . . 35

8 25. Private interests . . . . . . . . 36

8 26. Personal characteristics . . . . . . 36

8 27. Political aid to members . . . . . . 37

8 28. Political motives . . . . . . . . 38

8. 29. Nomination of the Speaker in caucus . . . . 40

830. Formalities of election . . . . . . . . . 4I

8 31. Formalities at the close of a Congress . . . . . 45

\&3. Choice of a substitute for the Speaker . . . . . 49

83. Contested elections . . . . . . . . . . . 50

834. The great contested elections . . . . . . . $5 \mathrm{I}$

8 35. New Jersey contest of 1839 . . . . . 52

8 36. Free Soil contest of 1849 . . . . . . 53

837. Republican contest of 1855 . . . . . 56

38. Impending Crisis contest of 1859 . . . . 60

\section{CHAPTER III.}

THE PERSONAL ELEMENT IN THE SPEAKERSHIP.

8 39. Early Federalist Speakers (1789-1801) . . . . 64 8. 40. Republican Speakers (1801-1811) . . . . . . 68

841. Speakership of Henry Clay (1811-1825) . . . . 69 8 42. Clay's election in $181 \mathrm{I}$. . . . . . . 70 8 43. Clay as a presiding officer . . . . . 71 
844. Clay's personal activity . . . . . . 74

845. Clay as a party leader . . . . . . . 77

\$46. Clay's tact and dignity . . . . . . 80

84. Speakerships of Taylor and Barbour (1820-1827) . 82

848. Speakership of Andrew Stevenson (1827-1835) . 84

\$49. Speakership of Polk (1835-1839) . : . . . . 86

850. Speakership of Hunter $(1839-1841)$. . . . . 88

851. Speakership of Robert C. Winthrop (1847-1849) . 90

852. Democratic Speakers of 1849-1855 . . . . . . 93

8 53. Speakerships of Banks and Orr (1855-1859) . . 94

854. Speakership of Pennington (1859-186r) . . . . 94

855. General tendencies of the Speakership to 1861 . . 96

856. Speakership of Grow (186i-1863) . . . . . . 98

8 57. Speakership of Colfax (1863-1869) . . . . . . 98

85. Comparison of Colfax and Clay . . . . Ior

8 59. Speakership of James G. Blaine (1869-1875) : . 103

\$60. Blaine's use of parliamentary powers : . I03

81. Blaine's committees . . . . . . . 104

82. Blaine's controversy with Butler . . . . 105

86. Little Rock affair . . . . . . . . 108

84. Speakership of Kerr (1875-1876) . . . . . . 109

865. Speakership of Randall (1876-188r) . . . . . 110

866. Difference between Speakerships of Blaine and Randall . . . . . . . . . III

8 67. Speakership of Keifer (188I-1883) . . . . . . 112

868. Speakership of Carlisle (1883-1889) . . . . . I15

\$69. Speakership of Reed (1889-1891) . . . . . . 116

70. Speakership of Crisp (1891-1895) . . . . . . I18

71. Recent Speakers compared . . . . . . , 120 


\section{CHAPTER IV.}

THE SPEAKER'S PARIIAMENTARY PREROGATIVES.

\$ 72. Sources of the Speaker's powers . . . . . . 122

873. Responsibility of the Speaker . . . . . . . 123

8 74. Respect due the Speaker . . . . . . . . 125

\& 75. Opens and closes sittings of the House . . . . 126

876. Acts as mouth piece and representative of the

House . . . . . . . . . . . 127

877. Authenticates documents . . . . . . . 130

\& 78. Announces the order of business . . . . . 132

879. States the question . . . . . . . . . . . 133

\&80. Does not put questions in which he is per-

sonally interested . . . . . . . 133

8 81. Some freedom in stating the question from debate . . . . . . . . 135

8 82. Announces the vote . . . . . . . . 136

8 83. Appoints the chairman of the Committee of the

Whole . . . . . . . . . . 136

884. Speaker required to resume the chair when necessary . . . . . . . . 137

8 85. Appoints the Speaker pro tem . . . . . . I40

8 86. Powers and authority of temporary Speakers. 141 8 87. Use made of the privilege of appointment . . . 142 88. Refers bills, official communications, and reports

to committee or calendar . . . . . . . . 144

\section{CHAPTER V.}

THE SPEAKER'S VOTE.

8 89. The Speaker's vote not a casting vote . . . . . 147 §. English precedent. . . . . . . . . . $\$ 47$ 
8 91. Rules of the House of Representatives . . . . 149 892. Basis of the Speaker's vote . . . . . . . 151

83. Right to a member's vote . . . . . . . . 152

84. Practice of the States . . . . . . . . . 154

895. Speakers content with the present system . . . 156

8 96. Reasons determining the Speaker's vote . . . . I56 897. Speaker's vote given last . . . . . . . 158 8 98. Public statement of reasons . . . . . . . . I59

89. Question of a vote after the intervention of other business . . . . . . . . . 159

\section{CHAPTER VI.}

\section{MAINTENANCE OF ORDER.}

8100. Order on the floor . . . . . . . 161

8 ror. Order in debate . . . . . . . . . . . 163

8 102. Speaker decides questions of order . . . . . . 165

8 103. Decision based on precedent . . . . 166

8 104. Appeals from the decision of the Chair . . 167

8 105. Speaker may decline decisions . . . . . 169

8 106. Questions left to the decision of the House . 170

8 107. Difficulty of deciding questions of order . . 171

8 108. Speaker's influence through parliamentary

decisions. . . . . . . . . 173

\section{CHAPTER VII.}

\section{DEALING WITH OBSTRUCTION.}

8 109. Abuse of power by the minority . . . . 379

8110. Obstruction in the House of Commons . . . 181 
8 III. Refusal to vote.-Precedent of John Quincy Adams. 184

8 I12. Refusal to vote to make a quorum.-Increased use of dilatory tactics . . . . . . . . 186

8 113. Attempts to stop filibustering before 1890 . . . 187 \& 114. During the Force bill debate, 1875 . . . 188 8 11 5. Proposed amendment of 1880 . . . . . 189 8116. Mr. Reed's action on obstruction, 1890 . . . . I90 8117. Authority for quorum decision.-Practice of

Parliament.-Text writers . . . . . I94 8 118 . Bearing of the Federal Constitution . . . 196 8119. The roll-call not the constitutional test of a quorum . . . . . . . . . . 199

8 120. Rules of the House of Representatives . . 201 8 121. Rulings of other presiding officers . . . 201 ₹ 122. Decisions of English and State courts . . 203 \& 123. Precedents of the House of Representatives. 204 ₹ 124. Ruling on dilatory motions.-Justified by parliamentary law . . . . . . . . 207 8 125. Rules and practice of the House . . . . 207 \& 126. Question of the right of the Speaker to make final decisions . . . . . . 209

\$ 127. Rules of 1890 . . . . . . . . . . . . . 211

₹ 128. Decision of the Supreme Court . . . . . . 213 \&29. Present state of the rules . . . . . . . . 214

\section{CHAPTER VIII.}

POWER THROUGH THE COMMITTEE SYSTEM.

8 130. Appointment of committces . . . . . . 217

8131. Chairmen of committees . . . . . . . . 219 
PAGE

8 132. Manner in which the Speaker's prerogative is exercised . . . . . . . . . . . . 220

8 133. Restrictions in the use of the prerogative .222

8 134. Irresponsibility of the Speaker's power . . 228

8 135. Announcement of committees . . . . . . 231

8 136 . Change or removal of committee-men . . . . . 232

8 137. Special committees . . . . . . . . . . 233

838. Attempts to transfer to the House the appointment

of the committees . . . . . . . . . . 235

139. Attempts to restrain the Speaker by rule . . . . 240

8140. Power of the committees.-Origin . . . . . 24I

8 141. Control of all bills. . . . . . . . 242

8 142. Abuse of power possible . . . . . 244

8 143. Right of way in the House . . . . 245

8 144. The committees the real legislators . 246

CHAPTER IX.

POWER THROUGH RECOGNITION.

8 145. Parliamentary law and practice . . . . . 248

8 146. Rules and practice of the House of Representatives. 249 8 147. The Speaker's list . . . . . . . . . . 251

8148. Opportunities for influencing legislation . . . 253

8 149. Restrictions imposed by custom . . . . . . 254

8 150 . Absolute control of recognition claimed by Speak-

ers . . . . . . . . . . . . . 258

8151. Increasing tendency to use recognition arbitrarily. 260 8152. Suggestions for limiting the Speaker's power of recognition . . . . . . . . . 266

153. Criticism of the power of recognition . . . . 268 


\section{CHAPTER X.}

POWER AS A POLITICAL LEADER.

8 154. The Speaker the chief of his party . . . . . 270

\& 155. Tendency to personal power . . . . . . 272

8156. Chairman of the committee on Rules . . . . 273

8 157 . Steering committee . . . . . . 278

8158. Opportunities for leadership in the chair . . . 280

8159. Speeches at the opening of the House . . 284

8 160. Retention of a member's privileges . . . . . 289

\& 16r. Right of leaving the chair . . . . . 291

8 162. In Committee of the Whole . . . . . 292

8 163. Dangers . . . . . . . . . . 294

\section{CHAPTER XI.}

THE SPEAKER'S PLACE IN OUR POLITICAL SYSTEM.

8 164. Precedence . . . . . . . . . . . . 296

8165. Compensation of the Speaker . . . . . . : 297

8 166. Summary of the Speaker's powers . . . . . . 299

8 167. Causes of development.-Early tradition . . . . 302

8 168. Imperfect organization of the House . . 303

8 169. Centralization of power . . . . . . . . . . 307

\& 170. Necessity of making the Speaker responsible . 308

8171. Advantages of a responsible Speaker.-

Increased efficiency and harmony of legislation . . . . . . . . 310

8 172. Possibility of fixing responsibility for legis-

lation . . . . . . . . . 311 
PAGE

8 173. Improvement in the character of the House of Representatives . . . . . . . . 312

8 174. Increased popular interest in Congressional affairs . . . . . . . . 312

8 175. Objections.-Combination of parliamentary and political duties . . . . . . . . . 313

8 176 . Concentration of power opposed to democracy . . . . . . . . . 313

8 177. Constitutional objection . . . . . . . 314

8 178. Conservative objection . . . . . . 315

8179. A natural development the wisest . . . . . 316

8 180. The Speaker as the head of the legislative depart-

ment. . . . . . . . . . . 318

\& 18r. Early supremacy of executive . . . . 319

8 182. Causes . . . . . . . . . . . . 320

8 183. Relations of the President and Speaker . 321

8 184. The Speaker's present importance . . . . 323

8 185. The Speaker as an executive officer.-Connection

between legislative and executive . . . 326 8 186. Necessity of better adjustment . . . . 329

APPENDIX A.

Bibliography of the Speakership . . . . . . . 331

APPENDIX B.

List of the Presidents of the Continental Congresses and the Congress of the Confederation (1774-1788). 335

\section{APPENDIX C.}

List of the Speakers of the House of Representatives (1789-1895) . . . . . . . . . 336 


\section{APPENDIX D.}

Rules of the House of Representatives . . . . . 34I

\section{APPENDIX E.}

Extracts from the Statutes at Large relating to the Speaker. 368

\section{APPENDIX F.}

List of references to votes cast by the Speaker . . . 370 


\section{THE SPEAKER OF THE HOUSE OF REPRESENTATIVES.}

CHAPTER I.

GENESIS OF THE SPEAKER'S POWER.

7 HE first essential of deliberative assemblies is a 1 system of parliamentary practice. In coun8. Importance tries where the sense of political order of parliamen- is weak and self-control in debate is tary law.

wanting, popular government is exposed to the greatest dangers. This is amply shown by the Convention of the French Revolution. The Teutonic race has developed, as a part of its system of self-government, an observance of forms designed to facilitate debate. In England, the country which has longest enjoyed the privilege of a permanent legislative assembly, has been developed the most elaborate and valuable deliberative system. This system America has inherited. It is one of the most striking traits of our national character, a trait held in common with all English-speaking people, that we are willing, in the interests of liberty and self-government, to submit to self-imposed restrictions of parliamentary law. Judge Story said, when he left the presiding chair of the Massachusetts 
House of Representatives, "I have learned that the rigid enforcement of these rules, while it enables the majority to mature their measures with wisdom and dignity, is the only barrier of . the rights of the minority against the encroachments of power and ambition. If anything can restrain the impetuosity of triumph or the vehemence of opposition, if anything can awaken the glow of oratory and the spirit of virtue, if anything can preserve the courtesy of generous minds against the rivalries and jealousies of contending parties, it will be found in the protection with which these rules encircle and shield every member of the legislative body. . . ." "

The person through whom the enforcement of these rules is secured fills a most important and responsible position, not only in the parliamentary, but also in the political system. No body of rules shows more diversity than that which governs the choice and functions of the presiding officer, or as he has come to be called, the Speaker. It is the chief object of this work to show the remarkable development of the Speaker of the House of Representatives through the rules and practice of the House of Representatives. A necessary preliminary is to trace the development of the office through English and colonial usage down to the foundation of the United States government in 1789 . To that preliminary sketch this chapter will be devoted.

Since it is to England that we must always look for the germs of American institutions, we turn to the history of that country for the origin of the

${ }^{2}$ Columbian Centinel, January 18, 1812. 
Speakership. That we hear very little of the presiding officer of the early assemblies, perhaps

2. Appearance of a Speaker in the House of Commons.

sufficiently testifies to his small influence or importance: although the Commons must always have had some one to preside over their deliberations, the term "Speaker" first appears in England late in the fourteenth century: Sir Thomas Hungerford, in 1377, was the first person to whom was formally assigned the title and position of Speaker of the House of Commons. ${ }^{2}$

As the appointment of the Speaker was always approved by the King, this officer at first held probably a political position. ${ }^{3}$

Whatever his origin, in the sixteenth century the Speaker's subserviency to the Crown became very 3. The Speaker marked. The duties and responsibiliunder the Tu- ties entrusted to the presiding officer dors.

of the Commons made it a matter of importance to the King that he should favor the policy of the Crown, for it was the early custom that he should compose both the speeches to the King, and also those petitions which urged upon

'Called in the Record, "Monsieur Thomas De Hungerford, Chevalier, qui avoit les Paroles pur les Communes d'Angleterre en cest Parlement," etc. Rot. Parl. 5I, Edw. III., No. 87.-Quoted in Hansard, Parliamentary History of England, I, 35I.

2." The Speaker in the time of Richard II. was a minion of the King . . . and greatly the occasion of the misfortunes of those times."-Hansard, Parliamentary History, II, 590. The King admonished Chaucer in I4to to see that there were no "unbecoming words from the Commons," and that they did not attempt "anything inconsistent with decency."-Hansard, Parliamentary History, I, 308-9. 
the Monarch the pursuit of a certain policy or the enactment of a law; in the personal discussions, too, between the King and the Commons, the Speaker spoke for the Commons and put his own construction upon their resolutions; he had moreover considerable influence over the course of business in the House:such questions as he pleased ${ }^{4}$ out of several measures before the House at the same time, he could put that which the Crown preferred; he might frame a question from the turn of debate rather than from the motion of any particular member; it was his duty " when a bill is read . . . to declare the effects thereof to the House." $s$ The position was thus in two ways of influence: the Speaker not only interpreted the will of the Commons to the King, but to a large degree could, as presiding officer, control the business of the House.

If the Tudor Kings were to succeed in reducing Parliament to that position of entire subordination at which they aimed, it was necessary that they should possess in the Speaker an active partisan. The law gave to the King the right to confirm or reject the election of this officer; and under the Tudors it was customary, in order to avoid the friction of a refusal, ${ }^{6}$ for the King to nominate him before Parliament met; consequently the Tudor

- Cushing, Parliamentary Law, \$2003.

- Lex Parliamentaria, 272. See Hansard, Parliamentary History, I, 878, "The Speaker asks time to consider a long bill before he delivers it to the House."

- Lex Parliamentaria, 263. "To avoid loss of time in disputa. tion."-Gneist, History of English Constitution, II, 147. 
Speaker undertook to manage affairs in the House as far as possible in the interests of the Crown. Bishop Stubbs says,- - The result was that the Speaker instead of being the defender of the liberties of the House had often to reduce it to an order that meant obsequious reticence or sullen submission. ..." Speakers had to try to persuade the House to pass the bills the King favored, and to grant all the money he asked. A well-known instance of a Speaker completely subservient to the Crown is that of Hare, in 1540 . He had been sent to the Tower for offending against the King's prerogative, but by an entire submission to the King he received at the same time his liberty and the Speakership. ${ }^{8}$ His address at the end of the session, ${ }^{9}$ consisting merely of numerous compliments to his Majesty, is an example of the kind of speeches the Tudor Speakers made to the King.

Even Sir Thomas More could not keep his complete independence. When, in 1523 , Cardinal Wolsey came himself to demand money of the Commons, he was received with stubborn silence. $\mathrm{He}$ appealed in vain for an answer to his demands-

'Stubbs, Essays, 272.

Btubbs, Essays, 273.

- "The great world contains these several divisions, the divine world, the celestial and the territorial worlds. By the similitude of which man is said to be a little world, and hath also three parts, viz., a head, a heart and inferior members. And in likeness of these he asserted that the whole English government was constituted; in which the King was the head, the peers the body, and the commons the rest of the machine."-Hansard, Parliamentary History, I 546-7. 
"Every member held his peace." At last the Speaker fell on his knces and told the Cardinal with all reverence " that his Manner of coming thither was neither expedient nor agreeable to the ancient Liberties of the House;" and in conclusion said " that except all the Members present could put their several thoughts into his Head, he, alone, was unable, in so.mighty a Matter, to give his Grace a sufficient Answer." " The Cardinal," continues our authority, " rose in a rage and departed." But it is a significant fact that the next day More enforced the Cardinal's arguments, and the subsidy was granted. ${ }^{10}$ Sir Thomas Margrave, another Speaker under Henry VIII, was " a great instrument of the Reformation." 11 It is asserted in the Parliamentary History that " Speakers in Queen Mary's time were chosen for the reëstablishment of the Roman religion." 12 When under Elizabeth the House of Commons sank into comparative insignificance, its presiding officer became still more dependent on the Crown; if there were any bills in the House which Elizabeth did not approve, she used to demand them from him. ${ }^{13}$ And we find one instance cited in Lex Parliamentaria when "Mr. Speaker was sent for to the Court, where the Queen's Majesty herself gave him Commandment what to deliver to the House. The Speaker was commanded on his Allegiance not to read any Bills

\footnotetext{
${ }^{20}$ Parliamentary History, III, 29-33.

"Parliamentary History", IV, 390.

12 Parliamentary History, IV, 589.

"Aiken, Memoirs, 17.
} 
touching Matters of State or Reformation in Causes Ecclesiastical." 14 Thus the Tudor Speaker was not the servant of the House but of the King.

Under the Stuarts the Speaker's position reflected the struggle between the King and Parliament: ac4. Status of the cording as the Crown or Parliament Speaker under was uppermost, the Speaker was dethe Stuarts.

pendent or free. In the Parliament of 1628 , famous for the energy with which it stood for its liberty, is recorded a celebrated struggle with that officer. Sir John Eliot had offered a remonstrance concerning tonnage and poundage, and had asked to have the question put. The Speaker replied that the King had commanded the adjournment of the House, and he could put no question. But the Commons refused to acknowledge the right of the King to adjourn the House. "You are appointed our Speaker," they said, " and do you now refuse to be a Speaker?" The Speaker would not disobey the King, and rose to announce the adjournment. The Commons, however, were thoroughly aroused. Two members rushed forward and held him in his seat. "Mr. Speaker," cried Denzil Hollis, with an oath, "you shall sit still till it please the House to rise." Whereupon we are told that, with great " abundance of tears," he answered, "I will not say, I will not say, but I dare not; desiring that they would not command his Ruin therein, in regard he had been their faithful Servant, and would sacrifice his Life for the Good of his Country; but he durst not $\sin$ against the express Command of his Sove-

${ }^{14}$ Lex Parliamentaria, 274-5. See Hansard, I, 887-9. 
reign." But the House would not listen to him. He was held in the chair while a Protestation of the Commons was read, and then the House rose. ${ }^{15}$

The next Parliament did not assemble until 1640. At one of its first meetings, however, the conduct of the Speaker on the last day of the preceding Parliament was examined, and it was finally declared that, having refused to put the question as called upon to do at the time, he was guilty of a breach of privilege. ${ }^{16}$ Thus one of the first acts of the new Parliament was to declare the position of its presiding officer free from the tyranny of the Crown. And when, on January 4, 1642, Charles entered the House in search of the five members accused of treason and demanded knowledge of them from the Speaker, Lenthall dared only to fall on his knees and reply, "May it please your Majesty, I have neither eyes to see nor tongue to speak in this place but as the House is pleased to direct me, whose servant I am here." 17

During the Revolution of 1643 the Commons still. felt the necessity of having their choice confirmed. As the King was not then in a position to sanction the election of the Commons, the House, in 1647 , resorted to the singular expedient of presenting its Speaker to the Lords, who signified their approval as a matter of course. ${ }^{18}$ After the Restoration the

"Parliamentary History, VIII, 330-3. (Feb. 25, 1628.)

${ }^{16}$ Cobbett, Parliamentary History, XXXI, 198.

${ }^{17}$ Hansard, Parliamentary History, II, roog-II.

${ }^{18}$ Journal of House of Lords, IX, 558. Several times during the Revolution, however, the Commons chose a Speaker entirely on their own authority. See May, Parliamentary Law, 185, for instances. 
Crown party continued, when possible, to put its own creatures into the chair, and if it succeeded in finding any one sufficiently able and at the same time unscrupulous, the business of the House was conducted greatly to its advantage. A man of this kind was Sir Edward Seymour. It is said of him that " he was the most assuming man that ever sat in the chair. He knew the House and every man in it so well that by looking about he could tell the fate of any question. So, if anything was put when the Court party was not well gathered together, he would have held the House from doing anything by a wilful mistaking or misstating the question. By that he gave time for those who were appointed for the mercenary work, to go about and gather in all their party. And he would discern when they had got the majority; and then he would very fairly state the question when he was sure to carry it." 19 Such liberties, however, did not pass unnoticed at the time. In 1677 , open complaint was made of the partiality shown in putting questions. Sir Thomas Clarges observed " that the Speaker had usurped more of the attention of the House than any other member by giving his opinion; but if that opinion was to be considered in the sense of Parliament, and his patter was to supply them with sentiments, there was an end to the rights and privileges

19 Burnett, Ozn Time, II, 72. The special rule of the House, adopted in 1604, "that the Speaker is to explain, but not to sway the House with argument or dispute," " to give information but not to argue or to draw conclusions from this information," shows that this abuse had long been going on. See Hatsell, Precedents, II, 243. 
of the House; for the Speaker could misrepresent to the public the proceedings of its members, and thus would the idea of representation be destroyed." ${ }^{20}$ The custom of remarking on the pend. ing motion became subject to such flagrant abuse that it was eventually discontinued. ${ }^{21}$

The character of the office may be seen from the fact that its holder at the same time occupied important political positions, such as Treasurer of the Navy or Secretary of State. ${ }^{22}$ Sir Edward Seymour even attempted, in a debate on the state of the navy, to speak from the chair in his capacity as Treasurer of the Navy, but several members at once cried out that he could not speak without leave. And in 1673 complaint was made of this combination of functions: "You are too big for the chair and for me," one member said vehemently; " and you, that are one of the governors of the world, to be our servant, is incongruous." 23

The last time that the confirmation of the Speaker was refused for political reasons was in $1679 .{ }^{24}$ Seymour had made himself so popular, in spite of the tyrannical use of his privileges, that he succeeded in

${ }^{20}$ Cobbett, Parliamentary History, IV, I98.

21 In the reign of George II, under Mr. Speaker Onslow. Sir Fletcher Norton, in 1770 , attempted to revive the practice, and although no notice was taken of it at the time, it was referred to in a subsequent debate as putting a dangerous power in the chair, and the experiment was not repeated.-Cushing, Parliamentary Lazw, §1182.

${ }^{29}$ Hatsell, Precedents, II, $217,218$.

"Cobbett, Parliamentary History, IV, 589-591.

"Cobbett, Parliamentary History, IV, Iog2-IIII. 
winning the election over the nominee of the Crown. The following day, when he was presented to the King, Charles II. refused to confirm the election. This action was considered a usurpation of the rights of Parliament, and created great excitement. It was affirmed over and over again that the choice of Speaker was in the House, that the presentation of this officer was only a " solemn showing" him to the King; but that the King was bound in any case to confirm its choice. The debate lasted a week. Although the Commons were reluctantly obliged this time to accept some one else, no sovereign ever after ventured to dispute that the right of election lay in the House, and that the confirmation was a matter of form. By the time that the House of Commons had established the right to choose its own presiding officer the struggle between the House and the King for the control of the Speakership was near its end.

It was not until after the revolution of 1688 , however, that the Speakership became entirely inde5. The Speaker pendent, and even then the change was in the eigh- gradual. As late as the middle of the teenth century. eighteenth century we find Pitt saying in his argument against Grenville in the debate on the Stamp Act, "Even the Chair looks too often to St. James." 25 The office, in the eighteenth century, was in a transition stage: no longer subservient to the King to the same degree as under the Tudors, its occupant was not yet entirely unsusceptible to Court influence. It was not until "2 Hansard, Parliamentary History, XVI, Io6. 
another century that the just and impartial character which we at present attribute to the presiding officer of the House of Commons became a reality. ${ }^{26}$

To the American student the English Speaker of the eighteenth century is far less important than his 6. The Speaker predecessor of the sixteenth and sevenin the colo- teenth centuries, for from the latter, nies.

rather than from the former, was developed that form of political moderatorship which influenced the character of the Speakership of the House of Representatives. Among the customs and institutions which the colonists brought with them was the English parliamentary procedure with. its important feature, the Speaker. But, as all these institutions were modified and altered by new conditions, the Speaker in the colonies developed into a very different officer from the Speaker of the House of Commons.

The colonial custom of following the English precedent, gave to the House the choice of its pre7. Choice of siding officer, subject, usually, to the Colonialspeas- approval of the Governor, as the reper.

resentative in America of the British Crown. In some of the colonies the power of the Governor to withhold his approval was questioned; but as such pretensions on the part of the repre-

${ }^{26}$ Yet contrast the independence of Mr. Speaker Norton's address in 1777 with the flattery of the Tudor speakers. Mr. Norton said that when the country was already laboring under very heavy burdens, it had granted the King a revenue far beyond his Majesty's highest expense, and he then admonished the King to make a proper use of the funds which the Commons had so liberally granted.Massey, History of England, II, 307. 
sentatives were regarded as encroachments on the few prerogatives left to the Crown, they were strenuously resisted. We find two interesting struggles of this kind in the history of Massachusetts. In 1693, the second year of the Province Charter, the question of " the power of the governor to dismiss the Speaker" had, according to Palfrey, already come before the Board of Trade; the matter passed by without serious discussion, but in 1705 the General Court chose Thomas Oakes, the agent in England who had persistently opposed the Charter. Dudley withheld his approval and demanded a new election. The House thereupon voted that it was " not in the governor's power to refuse the election of a Speaker." Dudley still hesitated. But he needed the money which the House was ready to give as soon as he should cease to interfere in its organization, and therefore finally yielded. He wrote to the Lords of Trade that Oakes was “ a known Commonwealth's man, never quiet, nor satisfied with the government, but particularly very poor." 27

In I720 a similar struggle took place, this time ending in the triumph of the Governor. Cooke, a man of great popularity, and representing those who were most vigorous in their opposition to the policy of the Governors, was elected to the Speakership. Shute refused to confirm the election, at the same time sending a message to the House saying that the power he claimed was conferred by the English Constitution and by the Charter, and had ${ }^{27}$ Palfrey, New England, III, 273-4. 
been exercised by Governor Dudley. Hc advised the representatives to choose another man, with a reservation of their right until the authorities in England should be consulted. This by a unanimous vote they declined to do. Shute, therefore, dissolved the General Court and issued writs for another to be held in six weeks. It was composed of nearly the same members as the last, but as they did not wish to delay public business they no longer insisted on the election of Cooke; they protested, however, that they were acting under duress. ${ }^{23}$ The next House (1723) did not deign to communicate its choice to the lieutenant-governor. ${ }^{29}$ The home government took up the matter, and the Explanatory Charter of 1724 expressly affirmed the necessity of the Governor's consent in the election of the Speaker. ${ }^{30}$ It was probably from such experiences that the colonies learned the importance of the principle, afterward embodied in the Constitution without opposition, that every deliberative assembly should have the final choice of its own officers.

The parliamentary duties of the colonial Speaker seem to have been of secondary importance. His 8. Parliament- ability to preserve order and enforce the 8. Parliament- rules must have depended largely upon Colonial Speak- the individual character of the man. The ers.

often-related attempt to check Patrick Henry in the Virginia Assembly is the most striking instance of the Speaker's control of debate. That

\footnotetext{
${ }^{28}$ Palfrey, Nezw England, III, 877-879.

${ }^{20}$ Palfrey, Newe England, III, 403.

${ }^{20}$ Charters and Laws of Massachusetts, 39-40.
} 
this colonial officer had any special political duties, like the appointment of committees, does not appear from accessible records. Among the rules adopted by the Pennsylvania Assembly in 1767 we find the following: "That the Speaker have Power to nominate Persons for Committees, and that none who are nominated refuse the Service; not that any of the Members shall be hereby debarred of their Privilege of nominating Persons, if they think fit, or rejecting such as are nominated by the Speaker; in which case the opinion of the House shall govern." 31 In the Pennsylvania Assembly the House seems to have had also the appointment of the chairman of the Committee of the Whole. ${ }^{92}$

But although the Speaker's opportunities for political influence through his parliamentary duties

9. The Colonial Speakers as political leaders. were not many, he was without doubt the leader of the House. The chief consideration in his election, so far as we can judge, does not seem to have been his knowledge of parliamentary law or his ability as a presiding officer; he was nearly always an active politician, the chief of his party, ${ }^{33}$ and put into office as the man with the push and the energy necessary to accomplish certain definite purposes. The choice of

"Journal of Pennsylvania Assembly, III, (1767).

"Journal of Pennsylvania Assembly, II, (1682).

"John Robinson, who was speaker of the Virginia House of Burgesses twenty-six years, filling the chair during the debate on the Stamp Act, is described by Mr. Henry as " the acknowledged head of the landed aristocracy. As Speaker of the House he was also Treasurer of the colony and was altogether the most influential member of the body." - Henry, Life of Henry, I, 999. 
Speaker was usually supposed to indicate the temper of the House and its relations to the Governor. Thus the Massachusetts General Court attempted to change its presiding officer in I 720 " solely because the Representatives required a bolder leadership." s4

The Speaker preserved his political influence and turned it to greater advantage in the chair. The very moment he stepped before the Assembly he assumed the position of leader. The Pennsylvania Journal gives the following account of an address to the House in 1682: "About the fifth Hour in the Afternoon, the House sat, the Speaker assumes the Chair and puts the House in Mind of the Intention of their Coming, gives them Advice suitable to their present Undertakings, and bids them be mindful of their duties to one another." ${ }^{35}$ And again: "The Speaker assumes the Chair and gives religious and wholesome Counsel to the Members of the House." 36 In 1725 we find $\mathrm{Mr}$. George Clarke writing thus to Walpole: "The choice the Assembly have made of Mr. Philips to be their Speaker in the room of Mr. Livingstone, and ... have given a great turn to the Councils of that House; for, though they are heartily resolved to support his Majesty's government, yet the Governor does by no means approve of the means." 37

We can judge also somewhat of the Speaker's position by the appointments he often received. Thus

"Palfrey, New England, III, 376.

"Journal of Pennsylvania Assembly, VII, (1682).

30 Journal of Pennsylvania Assembly, XXII, (1682).

"Documents relating to the Colonial History of New York, 768-9 
the Speaker of the Pennsylvania Assembly was nearly always appointed on committees of Conference with the Council. ${ }^{38}$ In 1747 he was appointed on the committee of Correspondence, ${ }^{39}$ and in 1774 was chosen with two other commissioners to "attend the treaty proposed at Albany." 40 There seems, moreover, to have been no idea or question in the colonial assemblies that a member by taking the chair should give up his rights as a representative: in the New York Assembly the Speaker not only voted on all questions before the House, ${ }^{41}$ but also made motions from the chair ${ }^{42}$ in the Massachusetts Court it was customary for him to serve, like any other member, on committees of the House.43

Thus the colonial Speaker held a political office, not because of the nature of his duties, but because he was often the most forcible member of the House, and because there was no sentiment or tradition to

see Journal of the Pennsylvania Assembly, e. g. XXIX, (1682). "The Assembly desiring the Speaker, and two other Members to attend the President and Provincial Council, to inform them what they had done in Relation to the preceding Vote, Patrick Robinson meeting them in the street, in a threatening Manner said to the Speaker, 'Well, John, have a care what you do, I'll have at you when you are out of the Chair.'"-Journal, XXXIV, (1752).

"Journal of Pennsylvania Assembly, LXV, (1747).

“ Journal of Pennsylvania Assembly, XIX, (1774).

"See Journals of New York Assembly, XIX, (1743-65).

"See Journals of New York Assembly.

"See Journals of House of Representatives of Massachusetts Bay, e. g. May 27, 1726, Nov. 25, 1726, Dec. 15, I 726, June 2, 1727, June 7, 1727, Nov. 27, 1727 . Speaker reports from committees, Dec. 7, 1726, Dec. 9, 1726, June 14, 1827. 
prevent his remaining the leader, although he per. formed the duties of a presiding officer.

The office of Speaker did not preclude him even from heading an opposition against the government 10. The Speak- if backed by a majority of the House. er as head of The Governor of New York complained the Opposition. that the ". . . Assembly had passed some Extraordinary Resolves about the Court of Chancery which was all done at the suggestion of the Speaker (Adolphe Philips), who had lately lost a cause in Chancery, and against whom I had signed a Decree only two days before. The evident partiality of the House in being thus Directed by one that was a Party, and entering into his Resentment, made me think it necessary to dissolve them, and to publish an Answer to their Resolves made by the Council. ...."4

Edward Mosely, "this irrepressible lawyer," 45 chosen Speaker of the North Carolina House in 1715 , led the Assembly to adopt resolutions censuring Governor Eden for his conduct of affairs; ${ }^{46}$ and of the committee appointed to report certain grievances to the Lords Proprietors, Mosely was put at the head. ${ }^{47}$ Again, in 1773 the Assembly of North Carolina gave note of its temper by selecting " the sternest vindicator of colonial rights in all the province." 48 In North Carolina, indeed, the scenes be-

* Burnet to the Lords of Trade, Dec. 21, 1727. Documents relat. ing to Colonial History of New York, V, 847.

"Moore, History of North Carolina, 42.

${ }^{46}$ Moore, History of North Carolina, 42.

"Moore, History of North Carolina, 43.

- Moore, History of North Carolina, 151. 
tween the Speaker and the Governor became at times quite violent. ${ }^{49}$ On the other hand, in some of the colonies the Governors, in cases of important measures which they wished passed, sometimes sought this officer's assistance..$^{50}$ We need not look far for an explanation of the prominent and influential position of the colonial Speaker. Since he was the highest officer in the government elected by the people, he was felt to be their natural leader. The Governor, surrounded as he was by an appointed and frequently subservient Council, was independent of the legislature in a sense in which no English sovereign in the eighteenth century was independent of Parliament. The colonial legislature, therefore, endeavored to endow its Speaker with a power of resistance. ${ }^{51}$

That in the pursuit of his aims the Speaker sometimes abused the privileges of his office is shown in 1r. Responsibil- several instances. In 1716 the Assemity of Colonial bly of New Jersey wrote to Governor Speakers.

Hunter about expelling its Speaker, and alleged as the cause " that he had been capable to influence so many into a combination with him to make effectual his ill purposes." The letter continued to say that this was probably only weakness on the part of the members, and that on the proposed expulsion it was hoped they would return to their duty. ${ }^{52}$

${ }^{49}$ Moore, History of North Carolina, 97; see also 162.

" Colonial Records of Pennsylvania, V, 486.

" Perhaps the fact that nearly all the colonial assemblies gave their Speakers salaries may have had some slight influence in keeping the Speaker subservient to the House.

${ }^{32}$ New Jersey Archives, IV, 450-I. 
Another instance, from the New York records, shows that the Speaker did not consider himself merely the mouthpiece of the House, but in a certain sense responsible for its actions. The Assembly had prepared a remonstrance against certain proceedings of the government, and was resolved to compel its Speaker, attended by the House, to deliver it to the Governor. In case of refusal he was to be expelled. Mr. Graham, however, declined to do the bidding of the House, and was saved from expulsion only by an artifice of the Governor, who made him a member of the Council. The Assembly then chose in his place Mr. Gouverneur, who had drawn up the remonstrance. ${ }^{53} \mathrm{Mr}$. Graham's refusal to act as the organ of the House shows the political significance which was attached to the office. It would seem that the Speaker in the colonies, as leader of the House in regard to legislation, was exposed to the danger of losing his place whenever he could not carry the House with him. His political position was, therefore, much nearer that of the Prime Minister of England at the present time than that of the Speaker of the House of Commons.

The second series of presiding officers with which the founders of the government were familiar was

"s The Governor said in his letter to the Lords of Trade, ". . . Mr. Graham came to me with much concern and told me the Remonstrance was produced and read in the House, but that he would be torn to pieces sooner than bring up and read such a paper at the head of the House, which he said arraigned all the proceedings against Leisler and Milburn, and by so doing he said in terminus it would be cutting his own throat."-Documents Relating to Colonial History of New York, IV, 511 . 
made up of the Presidents of the Continental Congresses and the Congresses of the Confederation. ${ }^{54}$

12. The President of the Continental Congresses and of the Congress of the Confederation.

These officers were chosen for their influence and station..$^{55}$ At first Congress seems to have had the intention of choosing its presiding officer on the principle of rotation of States ; but the custom was broken by the election of Richard Henry Lee of Virginia, in 1784, Randolph of that State having been the first President ten years previous. After that the large States, Virginia, Massachusetts, and Pennsylvania, were again honored. New Hampshire, Rhode Island, North Carolina, and Georgia were never represented in the chair.

Few details can be found which throw any light upon the extent of the President's power as presiding 13. Powers of officer: it was probably, however, very the President slight, since Congress transacted all of Congress. important business in the Committee of the Whole; he does not seem to have appointed any committees, and the fact that the vote was taken by States ${ }^{56}$ probably operated to diminish his parliamentary power; it was Congress that filled vacancies in the chair caused by his temporary absence, ${ }^{57}$ but the chairman thus appointed was to exercise no other duty of the President than " to

${ }^{4}$ See Appendix B.

"Peyton Randolph, elected unanimously at the first Congress, had presided ably over the Virginia House of Burgesses.

"Journals of Congress, I, 7 .

"Journals of Congress, I, 39. 
keep order." Still the President possessed great influence indirectly through the prestige which he must have enjoyed as official head of the state: the President was the highest officer of the united colonies and as such possessed executive and diplomatic functions; since administrative work had not yet been differentiated, he was the rcgular organ of communication with the army, the States, the foreign ambassadors, and our ministers and agents abroad. ${ }^{58}$ Jay, when President of Congress, was even directed to write a letter to the States explaining the action of Congress in limiting the further emission of bills of credit, and calling upon them to provide the money necessary for the expenses of the Confederation. ${ }^{59}$ It was a most unusual mode of procedure, the ordinary course being to appoint a committee for such a purpose. Jay made a stirring appeal to the States to perform their duty to the country in the alarming condition of the public credit, and his letter was unanimously approved. Occasionally Presidents of Congress exercised powers not unlike the most extreme claims of later Speakers. John Adams, in his Diary, speaks of a resolution introduced and seconded in the Congress by himself and Mr. Richard Lee, which was not entered on the Journals, and says that he can give no other explanation of this omission than that John Hancock was President, Mr. Harrison chairman of the Committee of the Whole House, and Mr.

* It was decided, however, that the duties of the President ceased on the adjournment of Congress.- Journals of Congress, IV, $43 \mathrm{I}$.

"Journals of Congress, III, 350-358. 
Thompson Secretary; and Mr. Richard Lee and Mr. John Adams were no favorites of any of them. ${ }^{60}$ John Hancock, at least, considered his position as presiding officer entirely subordinate to his influence as one of the leaders of the Continental Congress. A moderator usually considers himself the representative of the assembly over which he presides; but after Hancock was placed in the chair he began to oppose those who had secured his election; in decisive measures against Great Britain he hung back, and did not hesitate to obstruct the Declaration of Independence. ${ }^{61}$

Perhaps the most interesting example of the President's real position in Congress is Laurens's resignation in 1778. An attack had been published upon Lee and Congress. Great excitement prevailed. "Mr. President Laurens brought the newspaper with him to the House, and from the Chair proposed that it should be read, in order that it might become the subject of certain resolutions. The House not thinking it proper to come into that measure, he resigned the Chair, saying that he could no longer hold it consistent with his honor. They were disgusted and adjourned. The next day his friends attempted to replace him, but did not succeed; a new President was elected." 62

The correspondence of the Presidents shows that all the affairs of the country were communicated to them: evidently they could lay matters before

${ }^{\infty}$ John Adams, Works, III, 5 I.

'1 Stephen Higginson, Life of Hancock, (published first in 1789).

${ }^{62}$ Pellew, John Jay, quoted from Jay MSS. (June 4, 1777.) 
Congress or withhold them, according to their discretion; the first step towards procuring the passage of a measure seems to have been to secure the support of the President. Thus we know, in spite of our scanty material, that the President of the Congress of the Confederation, although not mentioned by the "Articles," had the attributes of a moderator and also of a political leader. Although on the whole not a powerful officer, the double capacity of this chairman was undoubtedly reflected in the later Speaker.

The President of the Philadelphia Convention offers the most recent example of a presiding officer which the framers of the Con-

14. The President of the Constitution a 1 Convention. stitution had before them when they provided for a Speaker of the House of Representatives. Like the President of the Continental Congress he was chosen by ballot, and the result was the unanimous election of George Washington. The only rule of the Convention relating directly to the power of its chairman was that all questions of order should be decided by him without appeal or debate; and that " of two members arising at the same time, the President shall name him who shall be first heard." The committees were appointed by ballot. We have one striking example of the President's influence in the Convention. There was much hesitation over the amendment introduced by Gorham-probably at the suggestion of Washington-allowing one member for every 30,000 inhabitants. Washington rose to put the question; but before doing so "said that although his situa- 
tion had hitherto restrained him from offering his sentiments on questions depending in the House, and it might be thought ought now to impose silence on him, yet he could not forbear expressing his wish that the alteration proposed might take place." ${ }_{3}$ The influence of his words was immediately felt, and the amendment accepted.

The only clause of the Constitution relating to the Speaker reads thus: "The House of Repre-

15. The Speakership clause in the Constitu. tion. sentatives shall choose their Speaker and other officers. ..." What the Speaker meant to those who drew up our instrument of government cannot be gathered from the records of the Convention, for there appears to have been no debate on this matter. The only discussion was upon a section introduced, ${ }^{64}$ though not adopted, that a Council of State be established " to consist of the President, the president of the Senate, the Speaker, the Chief Justice, and heads of departments." 65 Surely those who advocated this important board could not have thought of the Speaker as a non-political moderator, as a mere parliamentary officer whom it was necessary to dissociate from politics. What they intended must be inferred from that with which they were familiar: they knew a Speaker in the colonial assemblies who was at the same time a political

"Madison, Journal of the Federal Convention, 744.

- Introduced Aug. 22, I787, by the committee to whom the resolutions and propositions of the convention were referred for the purpose of reporting a Constitution: Rutledge, Randolph, Gorham, Ellsworth, and Wilson.-Elliot, Debates, IV, I48.

"Elliot, Debates, IV, I48. 
leader; they knew a presiding officer of Congress who was both a political leader and the official head of the state with important administrative functions; they knew a president of the Constitutional Convention who to his power as chairman added all the influence to be expected of one acknowledged as the foremost man of the nation. Few of their number had ever been in England, and there is no reason for. believing, as has been frequently asserted, that they provided for a Speaker similar to the presiding officer of the House of Commons. It is reasonable to assert that they expected the Speaker to be a political leader.

This a priori judgment, however, is not sufficient to know what the framers of the Constitution expected. We must now turn to the organization of the House of Representatives, which had the right by its rules and practice to define the actual status, powers, and duties of the Speaker: thus alone can we learn whether a new kind of office was created in 1789 or whether the precedents of a hundred and fifty years were to be followed; whether the Speaker was intended to be simply a moderator or whether he was to be a great political leader. 


\section{CHAPTER II.}

\section{CHOICE OF THE SPEAKER.}

$\mathrm{N}$ order to understand the parliamentary, the 1 party, and the political status of the Speaker of the House of Representatives, it is r6. Importance essential to study the process and the
of the subject. determining motives of the election for the Speakership. In the preliminaries of those choices, in the frequent contests attending them, in the pledges and combinations by which they are decided, we have a body of little-worked material which illustrates some of the most interesting phases of the office.

Let us look first at the precedents of English and of colonial practice. On the day appointed for the

17. Precedents -Form of election in House of Commons. first meeting of a new Parliament the Commons receive a summons to attend in the House of Lords, and there among other instructions, nominally from the Throne, they are directed to choose "some proper person" for their presiding officer. They return to the lower chamber and proceed at once with the election. In order that the Speaker may seem the choice of the House rather than of the ministry, the motion is generally made by a private member ${ }^{1}$ the person nominated rises

' Pitt wished to propose Mr. Addington himself, but Hatsell, on 
in his place, and the Clerk, also rising, points silently at him with his finger; if, as usually happens, no other candidate is brought forward, this person is then led to the chair by the proposer and seconder of the motion; if there is a contest the Clerk presides until a decision is made; the Speaker-elect before assuming the chair returns thanks for his election; then taking his place he receives congratulations from some leading member. The House thereupon adjourns and proceeds to the Lords to present its Speaker for the approval of the Crown; there this officer lays claim to the rights and privileges of the Commons, ${ }^{2}$ upon the confirmation of which the Commons retire. On returning from the House of Lords the Speaker takes the oath of allegiance and enters upon the duties of his office. ${ }^{3}$ Such has always been the form of choosing the presiding officer, except that before the present century it was customary for the Speaker-elect to make excuses, saying that others were more worthy, and praying a new choice, which was "commonly answered by a full consent of voices upon his name;" 4 and when he was presented to the King he again made excuses.

being consulted, said: "I think that the choice of the Speaker should not be on the motion of the minister. Indeed, an invidious use might be made of it to represent you as the friend of the minister, rather than the choice of the people." Pitt acknowledged the force of this objection.-May, Parliamentary Law, 182 ; note from Sidmouth's Life, 78, 79.

'Access to her Majesty, freedom of speech, freedom from arrests.

- May, Parliamentary Law, 180-5.

'Elsynge, 153. 
Although the old law which requires the sanction of the Speaker by the Crown still stands, this sanc18. English tion is now never refused. Under the precedent of a English form of parliamentary governparty speaker.

ment the Speakership is practically a Cabinet appointment: if the nominee of the Cabinet should not be elected, and the Crown should refuse its consent to the choice of the Commons, it would be a case of disagreement between the administration and Parliament, which must be remedied either by a new administration or a new Parliament : ${ }^{5}$ thus a deadlock in the choice of Speaker would be impossible in the House of Commons. There is usually, however, no political significance in the election of Speaker, and he often keeps his position during several changes of party: when, for instance, the reformed Parliament met in 1833 , Mr. Sutton, Speaker since 1817 , was reëlected, although he was not only a strong Tory but particularly opposed to the organization of the House. But in the next Parliament the majority elected Abercrombie, one of its own number: "I feel," said one man, "that the Speaker of the House of Commons cannot satisfactorily discharge his important duties unless his opinions and principles are in unison with the majority of the House;" 6 the election of Speaker, more-

'When in 1835 the candidate of the opposition, Abercrombie, was elected Speaker by a vote of 316 to 306 , Peel did not at once resign. He persevered about two months, until having been outvoted on several measures, he was finally obliged to resign.-Parlicmentary Debates, Third Series, XXVII, 9So-985.

- Hansard, Parliamentary Debates, Third Series, XXVI, 16. For whole debate, see $1-59$. 
over, was regarded as the "test of the strength of (a) political party:" 7 the opinion does exist, therefore, that he should belong to the majority. Still it is not strong enough to operate against other considerations: in $184 \mathrm{I}$, when there was a decided Tory majority in the House, the Prime Minister, Sir Robert Peel, supported "with great satisfaction" the Whig Speaker, Mr. Shaw Lefevre; ${ }^{8} \mathrm{Mr}$. Bryce tells us that Mr. Brand, although he had once been whip of the Liberal party, was reẽlected Speaker in 1874 by the Tories, who had then gained a majority, and served on until $1883 ;^{9}$ in 1895, Mr. Tully, a stanch Liberal, was reëlected by the Conservatives, receiving a unanimous vote. Yet when a vacancy occurs, either by death or resignation, the government appoints one of its own party. The chief requirements for the office are strict impartiality, and a thorough knowledge and experience of the rules and precedents of the House. Firmness, sound judgment, tact, temper, and courtesy, a clear mind and an upright character, are of course important considerations.

The colonies followed, as nearly as their circumstances permitted, the forms of parliamentary practice. The Assembly upon meeting was 39. Colonial accustomed to receive its instructions
practice.

from the Governor to choose a Speaker; it usually complied with his directions and immediately waited upon him to present its choice; then

'Hansard, Parliamentary Debates, Third Series, XXVI, 15-I6.

- Palgrave, House of Commons, 59.

- North American Review, CLI, 389. 
would follow an address from the Speaker, who would inform the Governor that he had been chosen to the office, and add an earnest request that being unworthy of such a great trust, the Governor would direct the Assembly to make another choice; whereupon the Governor would assure him that he approved the choice of the Assembly; the Speaker would then desire that those which were accounted the privileges of the House should be granted it; viz. free access to the Governor, protection from arrests and assaults, and a favorable construction of their proceedings; and that his own unwilling mistakes might be excused and not imputed to the House. ${ }^{10}$

The Federal Constitution provides that the House of Representatives shall choose its own Speaker, 20. Free choice by the House of Representa. tives. thus carefully avoiding the system of official moderatorship provided for the Senate. The colonial practice of subjecting the election of Speaker to the approval of another department of the government was also most carefully eliminated for reasons which cannot be better stated than in the words of Judge Story: "The free election by the Representatives secures a more independent and unlimited choice on the part of the house, according to the merits of the individual, and their own sense of duty. It avoids those inconsistencies and collisions, which might arise

${ }^{10}$ See Journal of House of Representatives of Pennsylvania, IV, I, 2, 23 (1774); VI, 2 (1767); Journal of General Assembly of New York, II, (1743-1765); Journal of House of Representatives of Massachusetts, May, 25, 1727 ; Moore, North Carolina, 152. 
from the interposition of a negative in times of high party excitement. It extinguishes a constant source of jealousy and heart-burning; and a disposition on one side to exert an undue influence, and on the other, to assume a hostile opposition. It relieves the executive department of all the embarrassments of opposing the popular will; and the House from all the irritation of not consulting the cabinet wishes." 11 It is not probable, however, that these excellent reasons were especially considered by the framers of the Constitution: there was simply no place in their scheme of government for a Speaker appointed or approved by the President: the fundamental idea of the Constitution was the separation of departments; if this was to mean anything the President could be given no hold upon the House of Representatives.

In the choice of its Speaker the House is hampered by no restriction of law or Constitution; but a custom based on parliamentary ${ }^{12}$ and on colonial precedents requires that the Speaker shall always be a member of the House. Strict parliamentary law dictates, moreover, that the candidate for Speaker shall not be a member upon whose seat there is any probability of a question. ${ }^{13}$ Nevertheless both Jones and Carlisle were elected Speaker with their seats contested and the question unsettled. The only necessary qualifications are, then, those required of

"Story, Commentaries on the Constitution, $\$ 68_{5}$.

13 "Lex Parliamentaria" gives the rule, "The Speaker . . is to be a Member of the House."-Lex Parliamentaria, 264.

${ }^{20}$ Hatsell, Precedents, II, 217. 
all members of the House of Representatives: the age of twenty-five years, citizenship, and the resignation of any other federal office.

The motives which govern the choice of Speaker lie deep in the complicated practice of American government, and the more hotly con2x. Principlea tested elections at the same time in-
of choice. clude some of the most interesting crises of American history, and illustrate the growing recognition of the Speaker's power. In practice, the choice of a Speaker depends less upon his qualities as a muderator, his experience as a public man, and his personal character, than upon the complex interplay of political factions striving for mastery in their own party. The Speaker is the party leader, but when the dominant party finds itself with no generally accepted chieftain, as was the case upon Mr. Carlisle's resignation to go into the Senate, the struggle for that position begins.

As the parliamentary duties of the Speaker ${ }^{14}$ are important, parliamentary knowledge and experience 22. Knowledge naturally have some weight in his elecof parliamen- tion. In every Congress there are many tary procedure. new members who usually know little or nothing of the rules of the House. They feel their ignorance and helplessness and say, "We must have some one to preside over us who really understands and knows all about these things." Nine Speakers had previously presided in their State legislatures : ${ }^{15}$

${ }^{14}$ See below, Chapters IV to VI.

"Muhlenberg, Trumbull, Sedgwick, Clay, Stevenson, Davis, Winthrop, Banks, and Blaine. 
Muhlenberg had been Speaker of the General Assembly of Pennsylvania and President of the Council of Censors of Pennsylvania, and is said to have had a recognized genius for presiding; Clay had presided over the Kentucky House with singular ability; and Winthrop had won a brilliant reputation as Speaker of the Massachusetts lower chamber. Previous service in the House has some weight, although it is never a decisive factor: Kerr had been a member of Congress for many years; Clay and Pennington were both elected Speaker on their first appearance in the House. The average length of congressional service before an election to the chair has been about seven years.

When the majority in Congress does not change, the Speaker is usually reëlected, unless meanwhile 23. Previous he accept some other elective or apservice as pointive office. There are, however, Speaker.

occasional exceptions to this rule: Polk was elected over Bell in 1835, Bell having disappointed his party; ${ }^{16}$ Hunter lost the reellection in $184 \mathrm{I}$, White being chosen as the more willing tool of the portion of the Whig party which desired and accomplished a change of policy at that session. Just before the opening of the Fiftieth Congress the newspapers freely suggested that Carlisle would not be reëlected for a third term: he had offended many members of his own party by his arbitrary use of recognition; his election, however, does not seem to have been seriously contested in the caucus. Several Speakers have served three terms; ${ }^{17}$ Ste-

${ }^{30}$ See below, \$49.

${ }^{17}$ Macon, Colfax, Bhaine, Carlisle. 
venson was elected four times; and Henry Clay was led to the chair six times, only leaving it in 1825 to become Secretary of State. Furthermore, even after an interval of minority life, an ex-Speaker would, as a general thing, be reëlected if his party should come in again: ${ }^{18}$ thus Mr. Carlisle might have been Speaker after the Congress of I889-9I, had he not preferred a seat in the Senate; and Mr. Reed, after four years in the minority, is expected to return to the chair in 1895 .

Among the complicated motives which govern the election for Speaker, not the least is the strife for sectional advantage. Although it 24. Sectional is universally admitted that a man is
claims. not fit for the Speakership who is capable of using his office for sectional ends-such as securing local favors through the organization of the committees, or undue influence in the conduct of business in the House-yet the cry of locality is always heard at the time of the election. Sometimes it is argued that a State has particular claims on the Speakership for some special service rendered the party, or for her constancy in returning a large majority, or, if a doubtful State, for giving any majority at all. There has been a feeling, moreover, that the States should share equally in the honors and spoils of the national government: thus the

10 There has been no instance of this, as the personnel of the House of Representatives changes rapidly owing to the impossibility of being at the same time a member of the House and an executive officer, and to the fact that either an executive position or a place in the Setuate is considered a greater prize than a seat in the House. 
Nation, in I88I, said, “A Speaker from New York is out of the question, because with the President and two members of the Cabinet, the Empire State ought to be content." 19 In 1881 Western Republicans agreed that the Speaker must be a Western man as a sort of compensation for the assassination of President Garfield. More violent than the strife of State against State was the strife of section against section which culminated in the contested elections of 1855 and 1859 .

Of much greater influence than any sectional claims in the Speaker's election are the many private schemes of individuals and corpora25. Private in- tions. Men with special interests to be
terests. advanced, or those anxious to obtain government subsidies in aid of some commercial enterprise, take an active part in the election of the man from whom they hope to get the most assistance; and since often their very fortunes depend upon the result, they make the most strenuous efforts to procure his election. If the struggle is close, the candidate whose friends can offer the best inducement to the trading element may be successful.

A very important factor in the Speaker's election is his personal popularity. The most famous Speak26. Peraonal ers-Clay, Winthrop, Banks, Colfax, character- Blaine, and Carlisle-have indeed almost latica.

all not only possessed those personal qualities which attract and hold adherents, but were also men of ability. Yet Mr. Colfax, although one of

"Nation, XXXIII, 428, 429. 
the most popular of our Speakers, holding his office for six years, elected by large majorities, received with enthusiasm, and finally leaving Congress amidst the sincere regrets and the ardent expressions of approval and gratitude of a unanimous Housè, was notably ignorant of parliamentary law. Clearly it was largely his personal characteristics which won him his great popularity and his reëlections.

If the party majority is small a Speaker must be chosen who will not be objectionable to the other side, for it is important that he should be sustained in times of high political excitement: of course a triumphant party does not consult the wishes of its defeated rivals, but its choice should certainly fall upon some one who can command their respect. The Speaker, moreover, must be a man whom his party can unreservedly trust: who will not injure its future to gain personal popularity or aggrandizement, or even-such has been and is still the general feeling-to secure legislation which he individually believes to be wise and expedient; but who will so organize the House, regardless of all personal interests and private feelings, that it shall act in harmony with the party.

Another consideration, which has great weight with new members, concerns the personal character 27. Political aid of the Speaker: new men come to to members.

Washington, some anxious for promotion and fame, many with high motives, earnest and zealous advocates of certain measures and convinced of their own ability to carry them out; yet for an opportunity to show their capacity 
for public usefulness and to gain national distinction, they are wholly dependent upon the good sense, justice, and good-will of the Speaker; a candidate, therefore, who has these qualities in a large degree, will be likely to gain their support. Clay showed an unusual and ready appreciation of ability when he placed Webster on the committee of Foreign Affairs on his first appearance in the House (1813).

The prospect of places on committees of course influences many votes. To how great, an extent pledges are given in regard to the committees, and how far different services are exacted and rendered in return for votes, is difficult to tell. Many men seem to regard the committee positions more as personal perquisites than as great national trusts to be administered for the public good.

Another important factor in the Speaker's election is the relative probability of success: who will win in the caucus? 'is what every one asks himself with the greatest eagerness, for it is well to be on that man's side as early as possible. Each candidate tries to make the waverers believe that he will win, and the waverers stand out as long as possible without committing themselves.

The motives, however, which have by far the most influence in the Speaker's election are purely 28. Political political. 'We have countless proofs of motives.

this in every campaign. During the contested election of 1859 , a member said: "I changed my vote for a high and honorable reason. . . . I asked Mr. Smith, "Will you organize the Committee of Ways and Means in such a man- 
ner as to protect the interests of Pennsylvania?' $\mathrm{He}$ would give me no satisfactory answer." $20 \mathrm{Mr}$. Blaine says of Mr. Grow's election to the Speakership in I86I: "He was chosen Speaker because of his activity in the anti-slavery struggles of the House, and because of his aptitude for the duties of the chair." ${ }^{21}$ The order in which these reasons is put is significant. Each member asks himself in regard to the various candidates, "Will this man constitute the committees as I wish, and will he allow the bills which I favor to be brought in?" The political opinions, therefore, of the various candidates are discussed before the caucus in a careful, exhaustive way which would be quite needless if the presiding officer of the House of Representatives were a mere chairman. In $\mathbf{1 8 8 3}$, for example, the tariff and internal taxation played the leading parts in the contest. Mr. Carlisle, a skilful parliamentarian to be sure and a man of great ability, was yet nominated above all as a tariff reformer, and as opposed to that abolition of the internal revenue system which Mr. Randall favored. ${ }^{22}$ The position of the Speaker of the House of Representatives, as no moderator but a party leader, is neither an accident nor a growth. It has been the intention and preference of the House ever since parties were first organized in $\mathbf{1 7 9 3 .}$

${ }^{20}$ Cong. Globe, 36 Cong. I Sess., 636.

${ }^{21}$ Blaine, Twenty Years of Congress, I, 324.

${ }^{22}$ Candidates sometimes owe their election in a large degree to the ability of the man who runs the campaign. Thus it has been said that Carlisle owed his election to Colonel Morrison. 
While the formal election takes place in the House at the opening of each Congress, the real election 29. Nomination has already been consummated in the of the Speaker party caucus. Although some conin caucus.

certed action must always have been necessary to produce a majority result, caucuses as we know them did not appear until towards the middle of the century. These bodies, known only in the custom of parties, have no foundation in law. They have been evolved from the necessities of the case, and serve well enough their purpose, as a place for the determination of party questions and the solution of party difficulties; and in them practically the Speaker is elected. As there have seldom been more than two parties of any consequence in Congress, it is usually known immediately after the congressional elections have taken place which of the two great parties-since 1856 the Democratic and the Republican-will have the majority of the House and consequently the Speaker. The question in the election of the Speaker is then simply which Republican or which Democrat it is to be. By means of the caucus this question, with all the heat and passion, the scheming and wire-pulling incidental to it, is transferred from the House to a body where the factions of party can fight freely against one another without alliance with members of the other party and without too freely exposing internal dissensions. ${ }^{23}$ As the candidate put forward by the minority,

2s The Speakership campaign begins, however, several months before the party caucus. As early as September, usually, each candidate takes up his headquarters at some hotel in Washington and the contest begins. 
however, usually leads the opposition, and is often consulted by the Speaker in regard to the minority representatives on the committees, and as he is likely to be put forward again if his party have the majority at the next session, his nomination is not purely complimentary. The difficulty in the way of carrying out caucus nominations will be considered below under Contested Elections. ${ }^{24}$

The Constitution of the United States leaves to the House not only the choice but the mode of choosing its presiding officer. The first 30. Formalities duty of every new House is to elect
of election.23

its Speaker. The Clerk of the last session calls the unorganized House to order, and, pending the election of Speaker, decides all questions of order ${ }^{26}$ the roll of members made up by the Clerk having been called and the presence of a quorum announced, the House, on motion of some member, proceeds immediately to the election of Speaker. The organization of the House used often to be delayed by the absence of a quorum: the First Congress of the United States was called to meet March 4, 1789, but it was not until April I that a quorum was present in the lower chamber. There is now, with the

"See below, §33.

26 The Speaker knows after one year of office, on account of our system of congressional elections, whether his power is to continue one year or at least three.

* Appendix D, Rule III, r. In some of the States, Alabama for instance, the Speaker of the lower House remains in office until his successor is elected and qualified.-See Poore, Charters and Constitutions, 964 . 
vastly increased facilities for travelling, no diffculty on this account. But in December, 1891 , the country witnessed the extraordinary spectacle of the adjournment of the House of Representatives because the ascendant party had not been able to agree as to which of its members should sit in the Speaker's chair. The House met on the following day, however, and the Democrats, having settled their differences, at once elected as Speaker Mr. Crisp, the person designated by the Democratic caucus.

It was long a question whether the election of Speaker or the right of a member to his seat presents a question of higher privilege and therefore of prior discussion, but since the act of March 8, 1863, ${ }^{27}$ the election of Speaker has always been given the precedence. At the beginning of the second session of the Forty-fourth Congress (1876) the Clerk decided that a resolution to proceed to an election of Speaker presents a privileged question, and that pending the decision of such a question, another question of privilege could not be submitted; an appeal taken from this decision was laid on the table. ${ }^{23}$

These preliminaries settled, the chairmen of the respective party caucuses nominate in the House the men chosen as candidates for the Speakership, and the question is then decided by a majority of votes cast. The manner of voting was changed in $184 \mathrm{I}$ from the ballot to a viva voce vote, ${ }^{29}$ a change pro-

${ }^{27}$ Appendix E, Revised Statutes, §XXXI.

${ }^{20}$ House Journal, 44 Cong. 2 Sess., 8. Yeas 165 , nays 84.

${ }^{20}$ Cong. Globe, 27 Cong. I Sess., 2. 
posed in several preceding Congresses. ${ }^{30}$ There was a growing feeling that every one ought to vote openly and be responsible for his vote, that if a man bolted the party nomination it was right that it should be known and the culprit punished accordingly. In 1880 this clause was dropped from the rules and a debate arose as to whether the rules should not state the manner of the Speaker's election, but it was decided that it might be an undesirable method of binding future Congresses. ${ }^{31}$ There is now, therefore, no provision in the rules in regard to the method of choice. If there be a definite third party, its candidate may be put regularly in nomination. Third parties have seldom had members enough to hold the balance of power, and they do not ordinarily make caucus nominations, but independent members sometimes make a separate nomination. Sometimes also, a discontented member refuses to vote for the nominee of his party: such was the action of Mr. Sherman Hoar in 189I. In general all the members of a party who are present vote for the caucus nominee.

After the announcement of the vote the Clerk declares the Speaker duly elected, and he is conducted to the chair ${ }^{32}$ by the candidate whom he has defeated in the party caucus and the leader of the minority. There he makes his acknowledgments to "House Fournal, I9 Cong. I Sess., 296. House Fournal, 24 Cong. $x$ Sess., 8. House Fournal, 27 Cong. $x$ Sess., 8.

${ }^{31}$ Cong. Rec., 46 Cong. 2 Sess., 553-4.

32 The origin of this custom was probably due to the desire to show that the taking of the chair was not a piece of presumption on his part. 
the House for the honor which has been conferred upon him. The oath to support the Constitution is then administered by the member who has been longest in continuous service. ${ }^{33}$ The oath is the same for Speaker and for members, ${ }^{34}$ but the question was raised, on one occasion, whether it did not have a different significance. When in $1848 \mathrm{Mr}$. Burt was elected Speaker protem., Mr. Winthrop being ill, several members advocated administering the oath a second time; Mr. Burt himself seemed inclined to think that it should be done; the general sentiment, however, was opposed to it as unnecessary. ${ }^{35}$ In the Forty-fourth Congress when S. S. Cox was elected Speaker pro tem., Garfield moved that the oath of office be administered to him, but the motion was negatived by a vote of 73 to $1700^{36}$ It might be fitting to recognize the Speaker's greater power by providing a special form of oath, as in the case of the President. The Speaker after himself taking the oath administers it to all other members present. ${ }^{37}$ The mace, symbol of the Speaker's authority, is then laid on the table and the organization of the House is complete.

${ }^{38}$ Formerly the oath was administered by the oldest member. See House Journal, 26 Cong. I Sess., 79-So. In the First Congress the oath was administered to the Speaker and members by the Chief Justice of New York, who attended by order of the House. The administration of the oath was delayed until April 8, the form of the oath not being agreed upon until April 6.-Annals of Congress, I Cong. I Sess., I0I, I05.

"Appendix E, Revised Statutes, $§ \mathrm{XXX}$.

${ }^{25}$ Cong. Globe, 30 Cong. I Sess., 855.

${ }^{36}$ Cong. Record, 44 Cong. I Sess., Ir $46-1153$.

${ }^{97}$ Appendix E, Revised Statutes, $§$ XXX. 
The ceremonies of the Speaker's induction into office have a pendant at the close of a Congress. It

3x. Formalities at the close of a Congress. is customary for a vote of thanks to be passed the Speaker for his " impartial, able, and dignified" behavior in the chair. It is an act of courtesy and not the judgment which the House passes upon its Speaker; still the same characteristics are not always emphasized, and even the word "impartial " has occasionally been left out. The motion is usually courteously made by some member of the opposite party, and it is sometimes accompanied by a short speech eulogizing more particularly certain prominent qualities. Under the practice of the House this is a privileged question and in order at any time. ${ }^{38}$ The Speaker calls upon some member to preside while the motion is under consideration. ${ }^{39}$ The vote is almost never a party vote, and is often unanimous; if not, the division usually expresses merely the dissatisfaction of individuals. Those who vote against the resolution are often new members who do not understand the difficult position which the Speaker occupies, or else, chagrined and disappointed that their first term in Congress has been so different from what they expected, lay all the blame upon the Speaker for the few opportunities they have had to take part in congressional affairs. Sometimes a member takes the motion literally instead of as a polite form, and if it does not express his opinion

${ }^{2}$ See House Journal, 20 Cong. 2 Sess., 388. House Journal, 23 Cong. I Sess., 879.

"See below, §80. 
of the Speaker's conduct, refuses it his assent. Thus John Quincy Adams says in his Memoirs: "I voted against the thanks to Jones. The testimony to his impartiality was too broad a lie for me to swallow." 40 Just before leaving the chair it is customary for the Speaker to make a speech expressing gratitude for the vote of thanks and for the confidence that has been shown him and the help given him: he often explains the difficulties of his position, and begs that if any unpleasant feelings have arisen, they may be dissipated and forgotten; he sometimes adds a tribute to the high character of the House, and usually ends with an expression of regret at their parting.

Mr. Reed's departure from office was an exception to the usual course of such occasions. In the first place the resolution of thanks was introduced by Mr. McKinley, a party friend; in the second place the Democrats as a body refused him even the formal courtesy of a vote of thanks; the vote stood yeas I 56, nays II 8 , not voting $55^{41} \mathrm{Mr}$. Reed's farewell speech was a most extraordinary and significant instance in the history of the House. In that moment when Speakers have always assumed the attitude of a mere moderator of an assembly, Mr. Reed stood forth as a leader of a party. He spoke

\section{"Adams, Memoirs, XII, 179.}

${ }^{11}$ Cong. Record, 51 Cong. 2 Sess., 38I7. When Carlisle left the chair, political as his Speakership had been, Mr. Reed offered the vote of thanks, the Speaker pro tem. spoke of the cordial feeling entertained by every member of the House towards Mr. Carlisle, and the resolution was adopted unanimously.-Cong. Record, 50 Cong. 2 Sess., 2726. 
of the Republican policy, and with all confidence in the result, left to time the judgment of the laws and proceedings of that Congress. After merely saying that he had no personal feeling towards those who had opposed him, entirely omitting all customary formalities, he turned in the most pointed manner and said, "To members on my left, with whom I am politically associated, I beg to tender my most sincere and heartfelt acknowledgments." 42

In the next Congress Reed offered the resolution of thanks to Crisp. He spoke of the dignity, honor, power, and influence of the Speakership, and said that this had not all been created to adorn an individual, but to maintain the well-being of the people of the United States. Perhaps nowhere is better set forth the nature of the Speaker's office.

" No factional or party malice ought ever to strive to diminish his standing or to lessen his esteem in the eyes of members or of the world. No disappointments or defeats ought ever to be permitted to show themselves to the injury of that high place. Whoever at any time, whether for purposes of censure or rebuke or any other motive, attempts to lower the prestige of that office, by just so much lowers the prestige of the House itself, whose servant and exponent the Speaker is. No attack, whether open or covert, can be made upon that great office without leaving to the future a legacy of disorder and of bad government. This is not because the Speaker is himself a sacred creation. It is because he is the embodiment of the House, its power ${ }^{12}$ Cong. Record, 5 I Cong. 2 Sess., 3825. 
and dignity. If efforts of that kind have been mace in the past, if at any time in the heat of passion or in the flush of resentment over unexpected defeat and overthrow, action has been taken which has been thus inimical to the public good and to the public order, let us leave to those who so acted the honor or the shame, and in no way give to their example the flattery of an imitation. While, therefore, my associates and I have not forgotten the past, I am sure that I speak the sentiment of them all when I say that the Republican party, without regard to what any other party may do, or what any other party has done, will buttress, by the respectful behavior of each and every one of its members, this high office.

"Therefore, placing patriotism above partisanship, placing duty above even a just resentment, notwithstanding we do not approve of the parliamentary law of the Speaker and his associates, and deem that the system reëstablished is undemocratic and unwise, nevertheless, by offering the customary resolution, we tender to the Speaker of this House the expression of our belief that he, like all his predecessors, has performed the trying duties of his office with upright intention and honorable purpose." 43

At the end of the next Congress, however, Mr. Reed declined to vote upon the resolution of thanks moved to the same Speaker.

The rules allow the Speaker to appoint a substitute for one day, or in case of illness for any period "Cong. Record, 52 Cong. 2 Sess., 2614. 
not exceeding ten days, provided that his choice has the approval of the House at the time it is made. ${ }^{4}$ 32. Choice of a In the Speaker's omission to make an substitute for appointment, or absence for a period the Speaker." exceeding ten days, the House elects a Speaker pro tem. ${ }^{46}$ This place is much valued for its dignity and for its possible influence on a later election. The right to supply the Speaker's place temporarily is freely used: the Speaker, contrary to the practice of the House of Commons, frequently leaves the chair, either to rest from his monotonous and onerous duties, or to look after his political interests. No formalities are necessary in making a substitute for one sitting: it is not even necessary to announce the name of the substitute to the House, and if the latter is in Committee of the Whole, the Speaker appoints some member to take the chair and preside when the Committee rises. It is customary, however, in the appointment of a Speaker pro tem. for a period exceeding one day, to proceed in a more formal manner: he is not only formally conducted to the chair, but usually makes a short speech declaring his wish to show strict impartiality in the execution of his duties, and begging the coöperation of members in the maintenance of order and their support in all cases of official decisions; the Senate and President are then notified

"Appendix D, Rule I, 7.

"See below, \$85.

${ }^{46}$ Appendix D, Rule I, 7. The House used sometimes to adjourn when the Speaker was ill for but one day. Examples, Annals of Cong., 12 Cong. I Sess., 1433. House Journal, 14 Cong. 2 Sess., 44. House Journal, 21 Cong. 2 Sess., 7. 
of the appointment. At the end of his service a vote of thanks is usually passed. A Speaker protem. elected for more than one day is entitled to be recognized as a Speaker of the House of Representatives. ${ }^{47}$

In the House of Representatives the course of an election for Speaker does not always run smoothly: if no party has a majority or if party 33: Contested lines are loosely drawn, a Speaker is not always chosen on the first ballot. The first contested election was in 1809 , and is interesting on account of the parliamentary question involved. Varnum received 60 votes, Macon 36 , Timothy Pitkin 20, Roger Nelson I, C. W. Goldsborough 1 , and 2 blank ballots were cast. If the blank ballots were not counted as votes Varnum would have a majority; otherwise there was no choice. The question arose of taking another ballot, and after some objection it was finally decided upon. Macon stated that he was not in sufficiently good health for the task of the Speakership, and asked his friends to vote for some one else. On the second ballot Varnum had a majority of 6 .

The next contested election took place November 13,1820 , on Clay's resignation. There was no choice as far as the seventh ballot and the House adjourned. ${ }^{48}$ The next day twelve more ballots were taken with no better result. ${ }^{49}$ November 15 th Taylor was elected on the twenty-second ballot. ${ }^{50}$ The

${ }^{17}$ McKee, Red Book, 77.

${ }^{18}$ Annals of Congress, 16 Cong. 2 Sess., 435.

"A nnals of Cong., 16 Cong. 2 Sess., 436-7.

-Annals of Cong., I6 Cong. 2 Sess., 437-8. 
trouble then, as in the more protracted contested elections which occurred later, was the slavery question: Taylor was elected as the anti-slavery candidate over Lowndes, the compromiser. In 1821 Barbour was not elected until the second day, and then on the twelfth ballot he received a majority of only one. ${ }^{51}$ In 1825 Taylor was again a candidate for Speaker and again did not secure the election on the first ballot, but on the second vote he received the necessary majority. When in 1834 , owing to Stevenson's resignation, a Speaker had to be chosen, it took ten ballots before John Bell finally received the election. ${ }^{52}$ In 1847 Winthrop was elected on the third, ${ }^{53}$ and in 1861 Grow on the second vote..$^{54}$ The four occasions upon which the Speaker's election was sharply contested, and long and seriously protracted, will be considered separately.

No better illustration can be given both of the principles and passions involved in the election of 34. The great the Speaker and of his place in our syscontested elec- tem of government, than the four great tions.

crises in the choice of Speaker, in 1839 , 1849,1855 and 1859 . In each of them the personal characters of the candidates were submitted to the most searching examination; in the approaches and plans, in the combinations and recombinations of those exciting days, much intrigue and bargain come to the surface; party spirit is seen at its strongest,

\footnotetext{
"Annals of Congress, 17 Cong. I Sess., 514-7.

" Cong. Globe, 23 Cong. I Sess., 421. See below, Chapter III.

ss Cong. Globe, 30 Cong. I Sess., 2. See below, $§ 5$ I.

"Cong. Globe, 37 Cong. I Sess., 3-4.
} 
and the whole political significance of the Speakership becomes clearly apparent. These'four protracted elections were a serious strain upon American institutions.

The question that prevented the organization of the House in 1839 was whether the election of Speaker or the decision of the New Jer35. New Jersey sey contested election case should be
contest of $x 839$. entered upon. The contest began when the Clerk in calling the roll asked if the names of the members from New Jersey should be omitted until the roll was completed..$^{55}$ The question was taken up with great eagerness. ${ }^{56}$ Without the New Jersey members there were in the House 1 I9 Democrats and 118 Whigs. The admission of either delegation from New. Jersey would give its party a majority in the House. But the Democrats, hoping that their present small majority would give them the Speaker, wished to delay the decision of the election case until after the House should be organized. Tumult and disorder reigned. The Clerk stubbornly refused to put any question to the House, declaring that he had no right to do so. After four days of disorganization John Quincy Adams rose from his seat and made an earnest appeal to the House to discharge its solemn and immediate duty of organization by proceeding with the roll-call, calling those members from New Jersey who held certificates signed by the Governor of the State." "But who

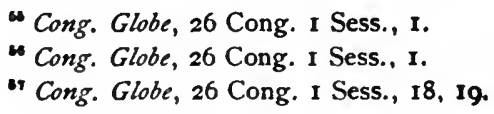


will put the question?" still urged a timid member. "I will put the question myself," replied John Quincy Adams: ${ }^{5}$ The Clerk attempted to make some explanation, but was cried down. ${ }^{59}$ It was moved that Adams take the chair, and carried "by an almost universal shout in the affirmative." $\infty$ The House in its emergency turned instinctively to that resolute and unflinching statesman. The debate continued, but Adams by his firmness and decision succeeded in controlling the House. Although his rulings were sometimes rather arbitrary, no one dared to dispute his authority seriously. Under his guidance the House by December fourteenth consented to vote for Speaker, refusing both delegations from New Jersey the right to participate in its organization. This decision was what the Democrats had been fighting for. But a small group, dissatisfied with the administration, separated from the great body of the Democratic party, and on the eleventh ballot, in alliance with the Whigs, chose as Speaker Robert M. T. Hunter, of Virginia, who had declared himself independent.

In 1849 , on account of the division of parties, another fight for the Speakership took place. The difficulty was that several Free-Soil 36. Free-Soi1 Whigs and Democrats had left their
contest of 849 . Whige respective parties and were acting independently, so that neither party had a majority of the whole. If Winthrop had received the support

\footnotetext{
${ }^{B 0}$ Cong. Globe, 26 Cong. I Sess., r9.

so Cong. Globe, 26 Cong. I Sess., rg.

${ }^{60}$ Adams, Memoirs, X, 147.
} 
of the Free-Soilers, ${ }^{61}$ he would have been elected. But Giddings and the more extreme Free-Soilers were not satisfied with the composition of his committees. Whether or not the territorial and District committees should be constructed in the interests of slavery was the burning question. It was felt that the time had come for the matter to be settled. The power that the Speaker possesses through the appointment of the committees was at the bottom of the contest. Thus it was twice proposed that to facilitate organization the Speaker should be divested of his power to construct the committees, and that they be appointed by the House. The proposal to elect a temporary chairman was opposed because it was feared that the disputed prerogative might be transferred to him. Mr. Giddings asserted that for years the committees had been formed to suppress all petitions sent to them praying the abolition of the slave trade. He was bound now, he said, to elect a Speaker who would arrange these bodies differently. Wilmot approached William J. Brown, of Indiana, a pro-slavery Democratic candidate, in regard to the committees, and received promises from him; but the correspondence leaked out, the whole South voiced its indignation, and Brown was obliged to withdraw from the contest. ${ }^{62}$

After a struggle of unprecedented length and seriousness, after fifty-nine votes had been taken

${ }^{61}$ The Whig candidate was Robert $\mathrm{C}$. Winthrop, Speaker of the previous House ; the Democratic candidate, Howell Cobb,

"Julian, Political Recollections, 74-6. 
and it was clear to all that the existence of a third group would render it impossible to elect a Speaker by a majority of the House, the resolution was carried that "if after the roll shall have been called three times no member shall have received a majority of the whole number of votes, the roll shall again be called, and the member who shall receive the largest number of votes, provided it be a majority of a quorum, shall be declared chosen Speaker." It was the first time in its history that the House gave up the principle of majority decisions. ${ }^{63}$ It was not strange, therefore, that the struggle against such an innovation should have been vigorous and determined. But necessity at last overcame all objection, and three weeks after the opening of Congress the final voting began. ${ }^{64}$ On the sixtieth vote Howell Cobbled; on the sixty-first, Robert C. Winthrop; on the sixty-second the numbers were even. Now was to come the decisive vote. The excitement was intense. On the sixty-third vote Howell Cobb received a plurality of two, and the three weeks' struggle was at an end. But even then, so irregular was this proceeding considered, it was thought necessary to ensure the validity of the election by a formal resolution: "That Howell Cobb a represen-

'In the House of Commons a majority is necessary to elect a Speaker, although in all other elections, even of committees of the House, a plurality is sufficient.-Cushing, Parliamentary Law, $\S 298$.

"On the first eleven votes Cobb had led. On the twelfth Cobb and Winthrop were equal, while on the next eleven Winthrop preceded Cobb. The voting then grew wilder. Up to the sixtieth vote sometimes Winthrop, sometimes Cobb, and sometimes others led. 
tative from the state of Georgia be declared duly elected Speaker of the House of Representatives for the Thirty-first Congress."

Southern suspense was now relieved. If the Whigs had elected their candidate in 1849 the Civil War might have been delayed, for the committees of this Congress affected the Compromise of 1850 . It is probable that Mr. Winthrop's prestige would have carried him into the Senate and eventually have affected the make-up of the Republican Party. The choice of a very pronounced pro-slavery and Southern man at this crisis undoubtedly aggravated the struggles of the following decade.

The next contested election, $1855-56$, $^{65}$ was for many reasons more violent and more protracted. 37. Republican contest of 1855 .

The old Whig party had fallen, and the combination of heterogeneous elements known as the "Anti-Nebraska men" held a majority; but so far was the majority from being united that no candidate could control the entire vote. The struggle was complicated by the demands of the Know-Nothings, who felt that in this moment they had found their opportunity. Since 1849 the struggle over slavery had been fearfully accentuated: the overshadowing question of the day was now liberty or slavery in Kansas; and it was at last clearly seen that in the hands of the Speaker lay to a great extent the decision of this question. At a conference of Republicans and Free-Soilers, held a few days before the opening of Congress, Giddings submitted the following resolution: "Re-

${ }^{\circ 6}$ Cong. Globe, 34 Cong. I Sess., 3-342. 
solved, That we will support no man for Speaker who is not pledged to carry out the parliamentary law, by giving to each proposed measure ordered by the House to be committed, a majority of such special committee; and to organize the standing committees of the House by placing on each a majority of the friends of freedom who are favorable to making reports on all petitions committed to them." 66 During the proceedings in the House the controlling influence of the Speaker over legislation through the appointment of the committees was affirmed again and again. Conscientious individuals urged in vain that members give up all hope of advantage to their views or personal ambitions by the construction of the committees, and unite on some one, in order that the House might organize and business proceed. " Let us persevere and elect a Democratic Speaker," said one member; " a Speaker elected by a partisan majority, however small, must necessarily give a partisan complexion to the committees." Said another: "I am unwilling to surrender the great power of the Speaker's chair without security for the future." Mr. Cadwalader said: "It is a subject of the gravest practical importance. . . . There are no fewer than six, perhaps seven or eight, standing committees of this House, whose permanent organization by any Speaker who may be selected will determine whether or not the slavery question, in all its various phases, is to be a subject of continual and repeated agitation against the views of a majority of the House."

"Julian, Life of Giddings, 321-322. 
It was proposed, as in 1839 , that the House overcome the difficulties of organization by appointing particular committees itself, but this suggestion met with little approval. The committees were arranged and rearranged, plan after plan proposed, compromise after compromise made, much time and labor expended on individuals susceptible to offers of committee places, and yet it was impossible to elect a Speaker. Each of the two great parties stood firm and immovable on the one main issue of the contest: the Democrats were determined that no bills should be introduced abolishing slavery in the District of Columbia or in the Territories; the Free-Soil party was now equally determined that a Speaker should be elected who would organize the committees in a manner hostile to slavery.

The struggle lasted two months. As in 1849 , the hope of obtaining a majority vote had finally to be abandoned. A hundred and twenty-nine ballots were taken and the House still remained unorganized : three months of the brief life of a Congress had gone and not one step had been made toward transacting the business of the country: the whole government was stopped by the question which only four years later was to prove incapable of compromise. It was decided that after three more roll-calls the highest number should suffice to elect. On the one hundred and thirty-third vote, therefore, Nathaniel $P$. Banks was declared Speaker of the House by a vote of 133 to 100 for Aiken and 100 scattering. Other political considerations besides slavery were concerned in his election. Mr. Banks was a skilful par- 
liamentarian, and had, moreover, much firmness and resolution; it was felt, therefore, that he would be able to oppose successfully the able tacticians who led the Nebraska men on the floor, in their attempts to prevent the admission of Governor Reeder as delegate from Kansas. The fact that Mr. Banks had been a prominent Democrat until the Nebraska issue was an additional reason for desiring his election, for this would prove that the Anti-Nebraska movement was not a trick to put the Whigs into power. He would, moreover, sympathize with the views of the American party on the questions arising under the naturalization laws. Still Mr. Banks was elected above all because it was expected that he would constitute the committees in favor of the Free-Soilers. He justified this expectation by putting a majority of anti-slavery men on the Kansas Investigation committee, which act practically delayed the settlement of the Kansas episode until after 1857 , and thus gave time for the anti-slavery forces to organize.

There can be no better proof of the importance attached to the Speakership in 1855 than the prominence given during this struggle to the fact that the election of Banks might mean the dissolution of the Union. The contest was preëminently a political one. As usual, nothing was heard of the necessary qualifications of a presiding officer, but candidates were subjected to the most minute examination of their political views. A resolution even was introduced that it was the duty of all candidates frankly and fully to state their opinions upon the important political questions involved in their election. It 
was still difficult, however, for all the members to grasp the Speaker's position: thus, after a speech dealing entirely with political questions, a member arose and demanded with surprise and indignant incredulity, "Do the great principles and interests of our country depend upon the man who may be elected Speaker of this House?" or The National Intelligencer also said: "The political power of the Speaker is exaggerated. The Speaker is always under the control of the House. We have the ludicrous spectacle of candidates being questioned one after another through the Chair as to their political opinions." Still in 1855 it was clearly and openly stated in the House that the Speakership was a political position.

Four years later, on the eve of the Civil War, the House of Representatives went through a similar 38. Impending struggle. ${ }^{68}$ The public mind was in a crisis contest state of intense agitation. Whether of 1859 .

that agitation was to be increased or diminished depended to a great extent upon the choice of Speaker. The House was composed of I09 Republicans, 88 administration Democrats, 13 anti-Lecompton Democrats, and 27 Americans. ${ }^{\infty}$ Thus no one party had a majority. On the first ballot Sherman received 66 Republican votes and Grow 43 ; but Grow at once withdrew his name,

" Cong. Globe, 34 Cong. I Sess., 318. A particular day was appointed for the examination of candidates.

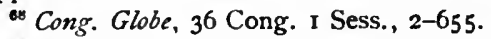

"Rhodes, History of the United States, II, 418; corrected from Carg. Globe and Tribune Almanac. 
and the Republicans united on Sherman. ${ }^{70}$ The great advantage of the Speakership was now fully realized. There was no need for members to remind one another of the political power which the Speaker possessed. It was clearly recognized by all, and the struggle on each side to gain that power was a desperate one. On the first day of the session a resolution was proposed that any one who endorsed the sentiments of Helper's Impending Crisis, a book hostile to slavery, was not fit to be Speaker of the House. ${ }^{71}$ The next day a second resolution stated that "it is the duty of every good citizen of this Union to resist all attempts at renewing in Congress or out of it the slavery agitation, under whatever shape and color the attempt may be made. And that no member shall be elected Speaker of this House whose political opinions are not known to conform to the foregoing sentiment." 72 As Sherman, the Republican candidate, had with some other members signed an endorsement of Helper's book, these resolutions were aimed directly at him. The ball thus set rolling, the discussion of slavery began, bitter and passionate on one side, eager and vehement on the other. The state of the country was reflected in the struggle for Speaker. The House was the scene of a confusion and uproar which the Clerk could not control. Threats of disunion were freely made. The galleries were packed with friends of North and South,

${ }^{70}$ Cong. Globe, 36 Cong. I Sess., 2.

"Cong. Globe, 36 Cong. I Sess., 3.

${ }^{12}$ Cong. Globe, 36 Cong. I Sess., 20. 
and the hisses and applause of the galleries increased the excitement on the floor. Bitter personal invectives nearly led to personal encounters. Senator Hammond wrote to Lieber: "I believe every man is armed with a revolver-some with two -and a bowie knife." is It seemed as if the Civil War was to begin in the House of Representatives.

The delay of the organization of the House was this time due chiefly to the Southern Democrats, but it is not to be supposed that they had not some more definite aim than the mere justification of slavery: they could not hope by their long speeches really to accomplish anything for their institutions. It was perhaps all pure filibustering, to prevent the organization of the House until after the Charleston convention of 1860 . By January 3oth the Republicans saw that Mr. Sherman, whom they had steadily supported, could not be successful. The most powerful obstacle to his success was the bitterness aroused by the recent slavery discussions. The Democrats feared, moreover, that his election would lead to such investigations as would reveal the unsoundness of the existing administration. There seemed also some danger of the Democrats electing Smith, of North Carolina. The Republican votes were therefore transferred to Mr. Pennington, of New Jersey, a new member who had no political record to arouse hostility. February I, 1860, nearly two months after the opening of Congress, he was chosen Speaker of the House on the forty-fourth vote, receiving exactly

"Rhodes, History of the United States, II, 424. 
II 7 votes, the number required to elect. It is interesting to notice, in the account of the proceedings of that day, that as soon as Mr. Pennington was really elected the demeanor of the Democrats changed, and they became at once respectful and civil in order to gain what little they could from a hostile Speaker. ${ }^{74}$

The Thirty-sixth Congress was the last one in which the Speaker's election was seriously contested. The quiet choice of Speaker since then has not been due to any decline of party feeling, or to any lack of the appreciation of the party advantage to be derived from the possession of the Speakership, but to the unity of parties and the possession of a clear majority by one or the other in each successive House. ${ }^{\text {T5 }}$

"It was noted during the swearing-in of members that such fireeaters as Lamar, McRae, Crawford, Houston and Reitt were especially respectful in their greetings of the Speaker, as they advanced to take the constitutional oath, the warm pressure of the hand and the profound bow seeming to say, 'Governor, we hope to have conspicuous places on your committees.' "-N. Y. Journal, Feb. 3, 1860 .

"There have usually been a few men to urge the necessity of great caution and deliberation in the choice of Speaker, since he might in certain contingencies become President of the United States. But the change of law in 1887 , which took the Speaker out of the line of succession, has removed this consideration. 


\section{CHAPTER III.}

THE PERSONAL ELEMENT IN THE SPEAKERSHIP.

THE Speakership is not only an institution, it 1 is an opportunity, in which men of strong 39. Early Fed- character have shown their leadership. eralist Speak- Such men have more than occupied ers [x789-180x]. the place, they have employed it, and handed down a growing tradition of dignity and power. The degree of influence which any individual Speaker attains depends as much upon the man as upon the office. A member of the House of Commons said in debate in 1620 , "Mr. Speaker is but a servant to the House; and not a master nor a master's mate."' Now the Speaker of the House of Representatives may be either a servant, a master, or a master's mate. The influence of an inefficient Speaker, both to do badly and to leave important things undone, may be seen in two incidents related of Andrew Stevenson by John Quincy Adams. On one occasion the old statesman had prevented the passage of a joint resolution carrying an appropriation: "Stevenson, the Speaker, from ignorance or carelessness, had suffered it to go to a third reading, even without reference to a committee of the whole, and when I asked him whether an appropriation could be made by resolution, answered, yes!

'Hatsell, Precedents, II, 239. 
Upon such slender threads hang the vital principles of our Constitution." 2 Again he writes that on account of "the Speaker's want of energy or his lukewarmness to the efficient adjustment of private claims, the House adjourned between three and four without passing a single bill." " They ought," he adds, "to have passed at least forty." 3 What strong Speakers can do may best be judged from what has been done by men like Clay and Carlisle and Reed.

Before analyzing and discussing the powers of the Speaker let us study the influence which individuals have had upon the development of their office. In the first two Congresses parties were not yet clearly enough defined to make permanent division possible. Since the jealousies between States still played a large part in politics, the fact that Frederick A. Muhlenberg came from the central and important State of Pennsylvania may have had much to do with his election. The reason for the substitution of Trumbull in the next Congress may possibly have been that suggested by Hildreth, - the principle of rotation in office. ${ }^{4}$ Still Muhlenberg had shown signs of a leaning away from administration measures, and Trumbull may have been more trusted. In the Second Congress, however, clearly defined party divisions began to appear from out the chaos of unorganized forces. In 1793 for the first time political combinations were made; the anti-Federal-

Adams, Memoirs, IX, III.

-Adams, Memoirs, X, 240.

- Hildreth, History of the United States, IV, 290. 
ists united on Muhlenberg for Speaker, and elected him by a small majority over the Federalist candidate, Theodore Sedgwick. In the Fourth Congress (I795-I797), although the Republicans had a small majority, the Federalists succeeded in electing Dayton Speaker by a vote of 46 to $3 \mathrm{I}$. This is almost the only instance we have of a man elected by a coalition of his own minority party with a part of the majority; the great Federalist historian thus explains the result: "All the Federalists voted for Dayton, as the only person at all connected with their party who had the slightest chance of success; while Dayton's personal influence, his former zeal for the sequestration of British debts, and the belief that he would hardly sustain a treaty, one of the articles of which seemed levelled at his motion on that subject, secured him the votes of many opponents of the administration." 5 It was, therefore, Dayton's emphatically expressed opposition to England which won over to him enough Republicans to secure his election. In the next Congress, Smith, of South Carolina, was leader of the Federalists in the House, but he had gone further than the leaders outside the House wished, and Dayton received a renomination and election. The choice of a moderate man proved favorable to the Federalists. It was to Dayton that Hamilton wrote urging certain measures on the Federal leaders. ${ }^{6}$ It was Dayton who succeeded, in obedience

- Hildreth, History of the United States, IV, 577.

- Schouler, History of the United States, 427; from Hamilton, Works, VI, 383 . 
to Hamilton and the other party chieftains, in modifying the address of 1797 by the insertion of a clause which professed pleasure at the proposed renewal of negotiations with France, and in putting upon it as far as possible a conciliatory imprint. ${ }^{7}$ The three first Speakers were respectable men, but by no means remarkable; the reason was simply that the House had not as yet attracted the ablest men in the country. It was not the fault of the House that its first Speakers were second-rate men: it put its ablest men into the chair. As the House gained in strength the Speaker gained in power.

In 1799 the Federalists found themselves with a decided majority, and elected Theodore Sedgwick over Macon by a vote of 44 to 38 . No one who reads the debates of that period can misunderstand Sedgwick's position. Although not one of the leaders of his party, he was one of its ablest members in the House. As has often happened to men of force in the Speaker's chair, Sedgwick made many enemies by decided and even partisan acts. He was Speaker during the debates on the repeal of the Alien and Sedition acts, and gave his influence and castingvotes in favor of the Bankrupt act ${ }^{8}$ and the Sedition acts. ${ }^{9}$ In 1801 two reporters applied to Sedgwick for seats on the floor. He refused on the ground that it would be inconvenient to the House; but it was believed that he was prejudiced by the fact that one of the applicants was editor of the National

' Schouler, History of the United States, I, 353.

- Annals of Cong., 6 Cong. I Sess., 534.

- Annals of Cong., 6 Cong. I Sess., 975. 
Intelligencer, and that the reports of both were intended for that paper. ${ }^{10}$ The reporters then applied to the House for admission, but were refused by Sedgwick's casting-vote. During the debate he took the unusual course of speaking from the chair in defence of his decision. So great was the feeling against him that the customary vote of thanks at the end of Congress recorded the names only of his party associates. ${ }^{11}$ Sedgwick's own feelings on the success of his Speakership may perhaps be judged from his closing speech, where he announced his intention to retire forever from Congress and public life. ${ }^{12}$

In I 80I Nathaniel Macon, of North Carolina, one of the leaders of the Republicans, was chosen 40. Republican Speaker ${ }^{13}$ and held the office for three Speakers [r8or- successive Congresses until 1807. He 1811].

was the first Southern member who was placed in the chair; his election was a part of the coalition between the Southern planters and the New York democracy by which Jefferson had been chosen to the Presidency. Macon served as Speaker during almost the whole of that extraordinary subserviency of Congress to the President, a subserviency shown by no succeeding Congress in our history. One of the ablest leaders of the House, he was a party Speaker, and a man of much personal influ-

${ }^{10}$ Hildreth, History of the United States, V, $4 \mathrm{II}$; Annals of Cong., 6 Cong. 2 Sess., 1038.

"A nnals of Cong., 6 Cong. 2 Sess., 1079. See below, $\S 73$.

${ }^{12}$ Annals of Cong., 6 Cong. 2 Sess., ro8o-r.

"Annals of Cong., 7 Cong. I Sess., 310. 
ence. ${ }^{14} \mathrm{He}$ is described by Mr. Adams as " a typical homespun planter, honest and simple, erring more often in his grammar and spelling than in his moral principles, but knowing little of the world beyond the borders of Carolina. No man in history has left a better name than Macon, but the name was all he left." ${ }^{15}$ A gradually growing opposition, however, manifested itself against Macon. In 1805 his election was secured with much diffculty: the Northern Democrats thought that it was time Southern domination should cease, and so brought forward a Northern candidate, Varnum of Massachusetts; it is probable, too, that they thought Macon too subservient to Randolph, whom they particularly disliked. In the next Congress Varnum was elected by a majority of one,$^{16}$ and in I809 secured a second election, although many Southern Democrats still supported Macon. ${ }^{17}$ Acceptable presiding officers though they were, and keen guardians of party interests, neither the early Federalist nor Republican Speakers were real party leaders.

The election of Henry Clay in I8I I marks an important step in the development of the Speak4r. Speakership ership. He was chosen to lead the of Henry Clay House and the country in the time of [1811-1825].

a great national crisis. Clay was the

${ }^{16} \mathrm{He}$ gave his casting-vote in 1806 against the proposed amendment to the negro importation act, "that no person shall be sold as a slave in virtue of this act."-Annals of Cong., 9 Cong. 2 Sess., 267.

${ }^{16}$ Henry Adams, History of the United States, I, 267.

10 Annals of Cong., to Cong. I Sess., $7 \delta 2$.

"Annals of Cong., 11 Cong. I Sess., 54. 
most popular of Speakers. Six times chosen to the office, his election was never seriously contested: often the vote which placed him in the chair was nearly unanimous, although it was not a period when the House was ready to follow any one, and during Clay's withdrawals there were close contests over the Speakership: whenever he chose to return he was elected Speaker by an overwhelming majority. The resolutions of thanks, usual at the end of each Congress, were with one exception voted unanimously to Henry Clay, and the enthusiasm which he aroused in the House was especially manifested on these occasions.

Several of Clay's biographers speak of him as " essentially and intensely . . . American," "as the best representative of our National Character." 18 $\mathrm{He}$ is certainly the most striking type of an "American" Speaker, as distinguished from the Speakers of other national assemblies. To Henry Clay the Speakership was one of the first political offices of the government.

In the autumn of $\mathrm{I} 8 \mathrm{II}$ the active young Republicans, who were boldly taking matters into their own hands, rebelled against their cau42. Clay's Electious elders and demanded a more vigorous policy. War with Great Britain was their ultimatum. President Madison was unfit to direct military operations. Congress had shown weakness and timidity. A crisis had come when the nation needed a new leader, and needed him in a position which should correspond 16 Anderson, Life of Clay, 37. 
to his consequence and power. The natural leader of that moment was Henry. Clay. That the place he was given from which to lead the country was the chair of the House of Representatives is a fact of great significance. His qualifications for that position are well-known: his service in the Senate; his successful experience as presiding officer of the Kentucky legislature; his firmness, which it was hoped would curb John Randolph; and above all his brilliant personal abilities, the combination of qualities which made him a natural ruler over men. Henry Clay was elected more than any other Speaker as leader of the House. Never before and only once since has a member been distinguished with the honor of an election to the chair upon his first appearance in the House. In the two instances the honor was conferred for exactly opposite reasons: while Clay was given the Speakership as the representative of a certain definite policy, Pennington was chosen in 1859 because it was impossible to elect any one with a definitely avowed policy. ${ }^{19}$

The new principles set forth during Clay's long service were: first, the increase of the Speaker's 43. Clay as a parliamentary power; secondly, the presiding off- strengthening of his personal influence; cer.

and thirdly, the establishment of his position as a legislative leader. As a presiding officer Clay from the first showed that he considered himself not the umpire, but the leader of the House: his object was clearly and expressly to.

' See above, $\S 38$, and below, $\S 54$. 
govern the House as far as possible. In this he succeeded to an extent never before or since equalled by a Speaker of the House of Representatives. Clay was the boldest of Speakers. He made no attempt to disguise the fact that he was a political officer. Speakers now, to be sure, following the example of such predecessors as Clay, seek to give their party every possible advantage from their position in the chair; yet, on occasions when nothing is to be gained by partisanship, they attempt to keep up the fiction of the Speaker as a parliamentary officer. But Clay had no thought of effacing himself in the least degree. He allowed no opportunity of expressing his attitude on the subjects that came before the House to pass unused. When in I 812 the repeal of non-intercourse came up, instead of simply throwing his casting-vote with the nays, he took occasion to express " the pleasure he felt in having opportunity to manifest his decided opposition to the measure." ${ }^{20} \mathrm{He}$ was the first Speaker, moreover, and one of very few, to vote when his vote could make no difference in the result. ${ }^{21}$ Often Clay was very arbitrary. When Mr. Winthrop became Speaker, Clay gave him this advice: "Decide promptly and never give the reasons for your decisions. The House will sustain your decisions, but there will always be men to cavil and quarrel over your reasons." 22 His conception of the Speakership was too wide for the canons of parliamentary law of

\footnotetext{
${ }^{20}$ Annals of Congress, 12 Cong. I Sess., 1546.

${ }^{21}$ See below, $\$ 93$.

29 Winthrop, Memoir of Henry Clay, 5-6.
} 
that time. When an aim was set clearly before him, he was too impatient to think of choosing between proper and improper means; he took the means which would most easily and quickly accomplish his end. With a fearless nature and abundant faith in himself, he was heedless of consequences.

An instance of his manipulations of the rules is seen in the way in which he stopped debate on the declaration of war, May 29, I8I2. Randolph had the floor. He was first informed by the Speaker that he could not proceed unless he submitted a motion to the House. He complied with the requirement, and again raised his voice to debate the question. Again he was interrupted by the ruling that there could be no debate until the House had consented to consider the proposition. The House took its cue and refused consideration; and Randolph, the thorn in the flesh of the majority, was thus thrust from the floor.

In a later instance, also involving John Randolph, Clay accomplished his ends only by a piece of decidedly sharp practice: on March 3, I820, Randolph moved that the vote of the preceding day on the bill embodying the Missouri compromise be reconsidered; Clay decided the motion out of order " until the ordinary business of the morning be disposed of;" a little later Randolph moved " that the House retain in their possession the Missouri bill until the period should arrive when . . . a motion to reconsider should be in order;" this motion, also, the Speaker refused to entertain; and when at last Randolph was allowed to bring 
up the compromise, the Speaker suavely stated that "the proceedings of the House on that bill had been communicated to the Senate by the Clerk, and that therefore, the motion to reconsider could not be entertained." 23

Clay's success in ruling the House was not due simply to the fact that he realized the parliamentary power of his office, but even more to his quickness in so using his position as to influence the mind of the House. Thus the duty of stating the question from the confusion of debate was one particularly suited to Clay's gifts. His ability as a parliamentarian is justly summed up in Mr. Winthrop's criticism when he says: " $\mathrm{He}$ was no painstaking student of parliamentary law, but more frequently found the rules of his governance in his own instinctive sense of what was practicable and proper than in 'Hatsell's Precedents,' or 'Jefferson's Manual. " "24 It is true that no decision made by Henry Clay was ever reversed by the House. But it is not true, as his biographers tell us, that harmony was the chief characteristic of his service. The House was " harmonious," not because it always agreed with the Speaker, but because he usually mastered it.

Clay's leadership in Congress was asserted not only in his opportunities as presiding officer, but also by his continued activity as an 44. Clay's per- individual member. In accepting the
sonal activity. Speakership he never for a moment

${ }^{23}$ Annals of Congress, 16 Cong. I Sess., I 588-9o.

24 Winthrop, Memoir of Henry Clay, 5-6. 
expected to deny himself the right to vote and to exercise his unrivalled talents as a persuasive debater. $\mathrm{He}$ at once took ground that tended greatly to strengthen the position of the Speaker. When casting his vote he never considered his position as presiding officer, but demanded and obtained the full force of a member's vote. ${ }^{25}$ Every subsequent Speaker has known, therefore, that in accepting an election he forfeited no privilege. Next to voting, the principal right of a member is to debate. Many of Clay's biographers assert that he frequently left the chair when affairs were not going as he wished, in order that he might give a new character to proceedings. A careful search in the Journals and Debates of Congress, however, reveals no evidence of Clay's speaking when the House was not in Committee of the Whole; and in Committee of the Whole the Speaker has the status of a private member, and may both speak and vote as he pleases. Henry Clay established the precedent of the Speaker exercising the right so freely that he virtually employed his prestige as Speaker on most of the important measures that came up. His practice, therefore, established the tradition that a party in putting a leader in the chair does not deprive itself of his services on the floor.

Clay went even further. It was half understood that as far as possible important affairs were to be discussed in Committee of the Whole in order that Clay's voice should not be lost. Once at least the records show that this was the object of going into ${ }^{26}$ See below, §93. 
committee. ${ }^{26}$ On one occasion Clay expressed his gratitude to the House for the commitment of a bill to the Committee of the Whole, as it offered him an opportunity of presenting his sentiments on the important topics involved. ${ }^{27}$ On another occasion he seems to have ventured on an implied reproof to the House for having omitted this attention to him. The House was in committee on the raising of an additional military force. The chairman was about to put the question on the committee rising, when Clay announced that he must delay them longer, and proceeded to make a little speech.

"When the subject of the bill was before the House in the form of a resolution it was the pleasure of the House to discuss it while he was in the chair. He did not complain of this course of proceeding; for he did not at any time wish the House from considerations personal to him to depart from the mode of transacting the public business which they thought best. He merely adverted to it as an apology for the trouble he was about to give the committee. $\mathrm{He}$ was at all times disposed to take his share of responsibility, and he felt that he owed it to his constituents and to himself to submit to their attention a few observations." 28

Other Speakers have been potent in the chair; and other Speakers, as Mr. Carlisle and Mr. Reed, have made speeches from the floor; but no other Speaker has ever so combined the functions of a

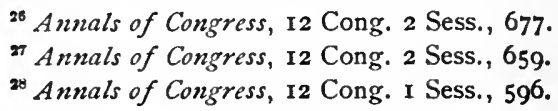


moderator, a member, and a leader. On many questions Clay framed the policy of the House, appointed the man who should guide proceedings from the chair of the committee, and himself took the management and control of the debate. The vigor and efficiency of Clay's rule are apparent in the contrast between the Congress of I8I4, when Clay was absent in Europe, and that of 1815, when he was again in the chair. While the first was notably incompetent, the latter has been characterized as the most active Congress that ever sat in Washington.

Clay's political influence and leadership extended far beyond Congress. He not only led the House, but during the first period of his rule 45. Clay as a the whole government seemed to fall
party leader. under his sway. Clay's Speakership may be divided into two periods, corresponding to the two presidential administrations of Madison and Monroe. Let us glance at the relative positions of Speaker and President in those periods. The comparison shows in the most striking manner to how great an extent the Speaker was a political officer. When Henry Clay took the chair his policy included war as its first object. To him more than to any one else was due the war of I8I2. The committees were at once constituted for war. Pressure was brought to bear on the Senate and Executive. On one occasion at least we know that Clay had a conference with the President, and the result of that conference was the confidential message of April I, recommending an embargo of sixty days. The 
President was not opposed to war, but was timid, and he resigned, with apparent willingness, the conduct of the foreign policy to the Speaker of the House of Representatives. With characteristic wit, Randolph summed up the relation of Clay and Madison thus: "After you have raised these 25,000 men, shall we form a committee of public safety to carry on the war, or shall we depute the power to the Speaker? Shall we declare that the Executive not being capable of discerning the public interest, or not having spirit to pursue it, we have appointed a committee to take the President and Cabinet into custody?" 29

The unusual appointment of the Speaker as one of the commissioners to negotiate the treaty of peace was a recognition of his services as originator and supporter of the war.

From the very beginning of Monroe's administration, in 1817 , the case was quite different. Clay at once assumed a position of open hostility to the President. Monroe refused to receive his course of action from the Speaker. In form the contest for supremacy was between the President and Congress; but Clay's practical success shows that when the legislative branch gains over the executive, it is the Speaker who gets the spoils of the battle. It shows also that in any such struggle the Speaker has the greater chance to win. Clay exerted all his powers in favor of internal improvements, a protective tariff, recognition of the South American governments, and the Missouri compromise. His pro"Annals of Congress, I2 Cong. I Sess., 707. 
posal to send a minister to the South American Republics was clearly an encroachment on executive powers. Yet all these great measures were carried through, little checked by the vetoes interspersed as warnings by both Madison and Monroe. It is not too much to say, therefore, that Clay was the most powerful man in the nation from 1811 to 1825. That he felt satisfied with the opportunities which the Speakership offered him is evident from his refusal of various executive appointments. In I 825, when he finally left the House, his chief reason was probably that the Speakership, however influential an office, is not considered a stepping-stone to the Presidency.

Clay's use of the Speakership satisfied not only himself but the House. It is a fact of the greatest significance that the cries of tyrant and despot, so often raised of late years against Speakers less domineering, were not then heard. Yet Clay added to the previously existing body of the Speaker's powers much more than has been added by any subsequent Speaker, even including Mr. Reed; and neither he nor any one else thought of excusing his actions on the ground of "the valuable services he had rendered to parliamentary law." He did what he did confessedly as leader of his party, to push through the measures he had at heart. Yet no voice was raised to cry " abuse of office." His enemies found nothing in his conception of the Speakership to denounce. His friends considered it a special claim to admiration. "His enlarged and commanding mind," says Mr. Foster, " could 
not be content to sit in inglorious ease and maintain the good order of an assembly, without endeavoring to infuse wisdom into their deliberations and aiding in an attempt to guide and influence their decisions." 30

How was Henry Clay able to carry out his conception of the Speakership? A part of our answer may be found in the personal qualifica46. Clay's tact and dignity.

tions which made him peculiarly fitted for the office. He displayed in the first place a remarkable tact, a tact which showed itself not only in his treatment of members, but also in the interpretation of his own privileges: few Speakers have known so well as Henry Clay how to measure their power so as to obtain the utmost possible, and yet not go beyond that unwritten standard of " fairness" which exists in every House of Representatives; how to observe the subtle yet essential difference between " political" and "partisan" action. His appointments of chairmen of committees and of chairmen of the Committee of the Whole were almost invariably from his party friends. Yet he sometimes made exceptions; perhaps the most graceful was the placing of Daniel Webster, in 1823, at the head of the important committee on Judiciary. ${ }^{31}$ His tact in dealing with

${ }^{30}$ Foster, Life of Clay, I3-14. The effect which Clay made on some minds may be seen from the following panegyric: "No man took a more prominent and decided attitude for vindicating the rights of the nation than Speaker Clay. Considerations of high and holy patriotism could only have impelled him to this, as his station would have given him a complete justification for a less responsible share in the action of the body."

"His tact is seen particularly in his treatment of Randolph, the 
men is well set forth by Benton. "It was necessary," he says, " to appoint a committee to investigate the charges of illegality and misconduct against the Secretary of the Treasury, Crawford. The committee was most unexceptionally composed by Clay -a task of delicacy, responsibility, the Speaker being himself a candidate for the Presidency, and every member of the House a friend to some one of the candidates, including the accused."

most unruly member in the House. On one occasion, for instance, Randolph came to him in hot haste with an abusive letter received from a member whom he had treated with extreme rudeness, and whom he now threatened to cowhide. "Don't you think," inquired Clay, "that he was a little out of his head to talk in that way ?" "Why, I have been thinking about that," said Randolph, "I have some doubts respecting his sanity." "Well, that being the case," replied Clay, "would it not be the wisest course not to bring the matter before the House? I will direct the sergeant-at-arms to keep a sharp look-out for the man and to cause him to be arrested should he attempt anything improper." Again when Clay took an opportunity to reprove Randolph for his indecorous conduct on the floor, Randolph excused himself on the ground of the Speaker's inattention to his remarks. " $\mathrm{O}$, you are mistaken, Mr. Randolph," cried Clay, "I frequently turn away my head, it is true, and ask for a pinch of snuff . . . [but] retentive as I know your memory to be, I will wager that I can repeat as many of your speeches as you yourself can." Whereupon Randolph, completely mollified, offered to shake hands and become friends.

Still another example of Clay's tact in controlling Randolph is perhaps worth mentioning. During the struggle over the Missouri Compromise Randolph came to Clay and said, "Mr. Speaker, I wish you would leave the Chair. I will follow you to Kentucky or anywhere else in the world." "That is a serious proposition," answered Clay, "which we have not time to discuss. But if you will come into the Speaker's room to-morrow morning, before the House assembles, we will discuss it together." They met, and Clay strongly advised against anything like secession, and in favor of a compromise.Harper's Magazine, V, 396 (1852). 
The House was, moreover, very proud of his bearing on occasions of ceremony, as, for instance, when Lafayette was received in the House of Representatives. They could not say enough then of his " superb dignity," "grace of manner," " the fitness of his words," and the " tranquil depth of his tones." 31a Still more was Clay's success due to his wonderful personal fascination which few could withstand. His manner in the chair must have been the ideal bearing of a presiding officer. Although prompt, firm, and decisive, his invariable courtesy and geniality prevented offence. All testify to the marvellous charm of his voice and manner, which attracted attention, awakened sympathy, and even compelled obedience. He had, moreover, a bold and commanding spirit which imposed its will upon those around him. He carried all before him by the irresistible force of his nature. Thus his personal magnetism combined with his imperious will to give him complete ascendency over his own party, and the easy leadership of the House.

When Clay resigned his office in 1820 , John $W$. Taylor, of New York, " a loose Constructionist, in

47. Speakerships of Taylor and Barbour [1820-1827]. favor of a protective tariff and an internal improvement system, and opposed to extension of slavery," $\$ 2$ was chosen to succeed him. He was a friend of President Monroe, and also a supporter of John Quincy Adams, and his election showed Adams's strength in the House. His reputation for ability

21 North American Review, LII, 147.

"Johnston, Politics, Sg. Sec above, § 33. 
as well as for impartiality is summed up by Niles's Register, which calls him an " able man whose conduct in the chair gave as nearly universal satisfaction as any one can ever hope to do." ${ }^{3}$ In the next Congress his election was contested by Philip P. Barbour, who scored a victory on the twelfth ballot. ${ }^{34}$ The opposition to Taylor has been attributed to his support of Clinton for President in 1812 , his proceedings on the Missouri question, ${ }^{35}$ and Calhoun's dislike-the result of an attack on the War Department while Taylor was Speaker. ${ }^{36}$ Barbour on the other hand favored Crawford for President, and was opposed to the restriction on Missouri and to the tariff bills. The Washington City Gazette said that the election of Mr. Barbour meant a complete triumph for the South. ${ }^{37}$ Barbour's Speakership was narrow and partisan: Taylor was ignored, and Barbour presided in the interest of his faction. In the next Congress (1823-25) Clay was again Speaker and had the famous opportunity of carrying his friends over to complete the election of Adams to the Presidency. After his acceptance of the Secretaryship of State, Taylor was elected by a small majority (99 to 94 ), ${ }^{38}$ and served half way through Adams's administration.

"Niles's Register, XXI, 242.

"House Journal, 17 Cong. I Sess., 7. See above, §33.

"Niles's Register, XXI, 242.

${ }^{30}$ Schouler, History of the United States, III, 244. Here we have an example of the Speaker's being held responsible for the action of the House.

${ }^{37}$ Quoted in Niles's Register, XXI, 242.

"Debates of Cong., I9 Cong. I Sess., 795. See above, $§ 33$. 
In I827 Andrew Stevenson, of Virginia, was elected to the chair, which office he held seven 48. Speakership of Andrew Stevenson [1827-1835].

years. Of the strongly partisan character of Stevenson's Speakership there is little doubt. Always anxious to help his party friends, he was restrained little by the traditional limitations of his office, and parliamentary law and precedent were violated when in conflict with Stevenson's aims. No Speaker, except perhaps Macon, has been so distinctly the President's man as was Stevenson during Jackson's administration. For this reason General Root moved in 1832 that the investigating committee in regard to a national bank should be chosen by ballot. The vote was taken and stood 100 to 100 . Stevenson then gave his casting-vote against the motion, thus deciding to appoint the committee himself. ${ }^{39}$ How active a part Stevenson took in the affairs of the House while Speaker, is shown by the fact that a majority of his constituents, differing from him on the subject of the removal and restoration of the public deposits, demanded that he should either change his course of action or retire; either of these courses, Stevenson declared in a letter of May 9, 1834, he was willing to pursue. ${ }^{40}$

For his subserviency to the President Stevenson received due reward. Jackson had accused Clay of a "corrupt bargain" for rendering, as he believed or professed to believe, certain services in exchange for a Cabinet appointment. But as early as April,

${ }^{29}$ Cong. Debates, 22 Cong. I Sess., 2128-2129.

${ }^{40}$ Niles's Register, XLVI, 251. 
1833, Stevenson had an official assurance from the Secretary of State that he was to be appointed to the British mission. The nomination was not made until May, 1834, after nearly six months of Congress had passed. It seems probable that the President first placed the Speaker under obligation to him, and then delayed the actual nomination in order to reap the immediate fruits of his favor. Jackson wished particularly at that moment that the committees charged with the investigation of executive measures should be favorable to him, and above all he had at heart the accomplishment of the removal of the public deposits. How far Stevenson yielded to executive influence, and how far he followed simply the dictates of his own reason, it is difficult to say. But it is significant that by his action during this session he separated himself from his constituents. It is also noteworthy that in the composition of the committees and in the discharge of his other duties he was often considered unfair and partial. It was nearly a month after his resignation that the customary thanks were voted him. The reward of the mission to St. James, slow in coming, was almost snatched away: the Senate with much indignation refused to confirm the appointment of Mr. Stevenson. Two years later, however, in 1836, Stevenson was again nominated and this time his appointment received the necessary confirmation.

The two candidates for Stevenson's mantle were both from Tennessee: John Bell, in 1860 the Union party candidate for President; and James 
K. Polk, in 1844 elected President. Polk had been working vigorously for the administration, and 49. Speakership was preferred by a majority of the of Polk [8835- Democrats; but the more moderate 1839].

men did not like the extreme partisanship he had shown, and owing to this division the opposition succeeded in electing Bell on the tenth ballot. ${ }^{41}$ John Quincy Adams said of him: "He is on the whole a good Speaker, and impartial so far as he dares, though occasionally subservient from timidity." 42 The Globe accused Bell of befriending the administration, saying that owing to the circumstances of his election he dared not do otherwise; but Bell took pains to refute this accusation in Niles's Register. ${ }^{43}$

At the opening of the next Congress Polk won an easy victory, ${ }^{44}$ Bell having been, according to Schouler, "read out of the Democracy for supporting Judge White's claims for President." 45 Two years later, however, when Polk was reëlected, his majority over Bell was only thirteen. ${ }^{46}$ Polk was an industrious worker, a skilful presiding officer, and an able Speaker, but he was distinctly a party Speaker and created much opposition in the House. Like Stevenson, Polk was accused of having used the chair in his zealous support of the President. So jealous has the House ever been of all that has

"See above, $\S 33$.

"Adams, Memoirs, IX, 214.

"Niles's Register, XLVIII, 229-232.

"Vote, I32-84, 9 scattering.

"Schouler, History of the United States, IV, 221.

4 Cong. Globe, 25 Cong. I Sess., 3. 
seemed like the interference of another department of the government, that then, as now, it was one thing for the Speaker to use his political power to help the leaders of the House, and quite another to advance well-known presidential measures, even although the President might be of the same party as the leaders. Adams accused Polk of appointing the committees " in favor of the Administration " 47 and of being " partial." 48 But Polk obtained some reputation, which probably suggested him as a candidate to kill off Van Buren in the Democratic convention of 1844 . At the close of Polk's administration the vote of thanks was carried only after long debate; the vote showed 94 in favor and 57 opposed, an extraordinary opposition to a resolution usually considered a mere formal courtesy. ${ }^{49}$

It must not be forgotten, however, how difficult it would have been for any one to have presided during those four years from 1835 to 1839 without causing irritation. In the first place those were the years of John Quincy Adams's most active service in the House. He was in constant conflict with the Speaker, he paid no attention to the rules when they put a check upon him, and to keep the Massachusetts champion in order may be reckoned as one of the duties of the Speakers of those years. Again, more appeals were made from Polk's decisions than

\section{Adams, Memoirs, IX, 466.}

${ }^{43}$ Adams, Memoirs, IX, 366, 387. Mr. Adams said openly in the House, in the bitterness of defeat, "I am aware that a slave-holding Speaker occupies the chair."-Cong. Globe, 24 Cong. I Sess., 498.

${ }^{40}$ House Journal, 25 Cong. 3 Sess., 696 . See above, §31. 
from those of any other Speaker. After the acceptance of the gag resolutions of 1836,1837 , and I 838 , Polk was justified, under the rules, in refusing to allow petitions upon slavery to be read, or to allow debate upon them or motions that they be referred. The constant struggles over the Speaker's decisions on petitions were, therefore, no reflection upon the Speaker: rules once adopted he was bound to enforce. At the time of the "memorable secession " of I 837, Polk was plainly outwitted by Slade, who managed to deliver an abolition speech. He got the floor through an oversight of the Speaker, and then, in spite of Polk's repeated calls to order, the blows of his gavel, and his demand finally that Slade should take his seat, the latter succeeding in holding the floor until some members managed to get a motion to adjourn through the House.to The bitterness of the Independent Treasury controversy also aroused hostility to Polk's decisions. Moreover, when the resolution of thanks was offered, Polk's connection with the State politics of Tennessee to some degree complicated the matter: a part of the opposition was based upon an unwillingness to sanction his pretensions to the Governorship. ${ }^{51}$

Hunter was placed in the chair in 1839 , by a 5o. Speakership union of Whigs and Democrats, after of Hunter[1839- the fierce contest arising out of the 184[].

New Jersey election cases. ${ }^{51 a}$ His claim

${ }^{30}$ Niles's Register, IIII, 260-I.

${ }^{61}$ Dallas, Life of Polk, I4. See also Cong. Globe, 27 Cong. 2 Sess., 395 .

s1a See above, $\$ 35$. 
to the office was the declared "independence" of his position, which meant that he had no very decided political views. John Quincy Adams characterized him in his Diary as a "good-hearted, weakheaded young man." ${ }^{2}$ His good intentions in the direction of fairness may be seen from a letter which he wrote his constituents in 1840 , announcing his intention of retiring from public life at the end of his term of service, or his willingness to resign at once if his constituents wished it. His reasons were that he could not support either Mr. Van Buren or General Harrison for the Presidency, and therefore could not reflect the opinions of his constituents on either side of the question. ${ }^{53}$ He made a fair presiding officer, but, as Adams said, he lacked " the spirit of decision." ${ }^{54}$ What attempts he made to influence his office were in a parliamentary direction. In his closing speech he said: " . . . It is something if I can hope I have made it easier for those who succeed me to act on some better principle than that of giving the whole power of the House to one of the parties without regard to the rights and feelings of others. Clothe this station with the authority of justice and how much may it not do to elevate the views of parties from themselves to their country! But arm it with the mere power of numbers and administer. it with an exclusive eye to the interests of a part and it may become the engine of as much fraud and oppres-

${ }^{62}$ Adams, Memoirs, X, 379.

${ }^{63}$ Niles's Register, LVIII, 3 II.

${ }^{64}$ Adams, Mcmoirs, X, I7o. 
sion as can be practised in a country as free as ours." 5

The Speaker's seat in the three succeeding Congresses was filled by White, Jones, and Davis, sec51. Speakership ond-rate men who were mere tools of 51. Speakership the leaders. White, it is said, owed
of Robert c. Winthrop his election to Henry Clay's influence, [8847-1849].

and no one doubts that he showed proper gratitude. There was violent opposition to the vote of thanks on the ground of partiality both in regard to the appointment of committees and parliamentary decisions. ${ }^{56}$ Jones has been characterized as a clever politician who made but an indifferent presiding officer. And Adams said of Davis, "The Speaker, a pro-slavery Republican from the free State of Indiana, buckled close to the slave-mongers." 57

But the succession of rather commonplace Speakers was broken by the election in 1847 of Mr. Winthrop, whose dignified incumbency is unlike that of any of his predecessors or successors: he was the last man in the chair who tried to put into practice the elevated principles set forth by Hunter. Mr. Blaine says that Winthrop gained his nomination in the Whig caucus over Samuel F. Vinton, of Ohio, because he had voted for the Wilmot proviso and Vinton against it. So far is this from true that Mr. Winthrop himself always stated that Mr. Vinton, his warm personal friend and twenty-five years older

\footnotetext{
ss House Journal, 26 Cong. 2 Sess., 379-380.

"Cong. Globe, 27 Cong. 2 Sess., 396-399.

${ }^{67}$ Adams, Memoirs, XII, 245.
} 
than Winthrop, might have had the nomination had he chosen. Instead he came to him and said: "I cannot be Speaker. It is too hard work for me; I am too old for it. You must be Speaker." Winthrop was therefore nominated with Mr. Vinton's hearty support. ${ }^{58}$ Political motives, of course, were as usual paramount in Winthrop's election; his Whig principles combined with his attitude on the slavery question made him a particularly acceptable candidate.

The election was close and Winthrop finally won on the third ballot by a majority of only one. ${ }^{59}$ It marks an interesting moment in our history, for we see now the beginning of that Free-Soil split so important two years later. Giddings and Palfrey did not vote for Winthrop. ${ }^{00}$ A letter of Giddings to Horace Greeley at this time shows a just appreciation of the Speaker's power. " [The Speaker] exerts more influence over the destinies of the nation than any other member of the government except the President. He arranges the committees to suit his own views. If a Whig in favor of prosecuting the war be elected Speaker, he will so arrange the committees as to secure reports approving of the continuance of our conquests in Mexico. If he be opposed to the war he will so arrange them as to have reports in favor of withdrawing our troops." 61

"This statement was made to the writer by Mr. Winthrop. Vinton was made chairman of the committee of Ways and Means.Cong. Globe, 30 Cong. I Sess., 19.

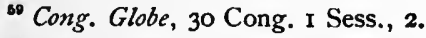

${ }^{\circ}$ Cong. Globe, 30 Cong. I Sess., 2.

${ }^{\circ 1}$ Julian, Giddings, 215-216. 
It was the personal qualities and parliamentary skill of Mr. Winthrop, quite as much as his status in the party, which made him eminently fitted for the Speakership. He had been Speaker of the Massachusetts House of Representatives where, says Blaine, " he earned so valuable a reputation as a presiding officer that some of his decisions have been quoted as precedents in the National House and have been incorporated in permanent works on Parliamentary Law." 62 The expectations formed of him were fully justified. His mastery of parliamentary law combined with his firmness and prudence, and the vigor and promptness with which he administered his parliamentary duties, made him the able leader of the House in its most stormy crises: and with Giddings and the ardent abolitionists on one side, Toombs, Stephens, and the Southern extremists on the other, the unfailing presence of mind and power of command which Winthrop displayed in times of excitement and confusion were much needed in the Thirty-first Congress. His dignity won the respect as his grace and courtesy won the good-will of the House. Seldom has the Speaker's chair been filled with equal distinction.

Winthrop's conception of his office was, however, entirely different from that of many who have occupied it: he was a strict parliamentarian and construed the parliamentary duties of his office narrowly; at the same time he knew that the Speakership was a political office: he tried to be both a ${ }^{62}$ Blaine, Twenty Years of Congress, I, 72-73. 
political and a presiding officer. He made no attempt to perform his political duties in other than a political fashion; yet he had a high ideal of the Speakership, and in the purely parliamentary duties of the chair he sought to forget party distinctions and to treat friends and foes alike. But however admirable Winthrop's conception of the Speakership, it did not accord with the forces already at work in the House of Representatives, and hence gave no permanent direction to the development of that office. In the hotly contested election of $1849,{ }^{63}$ Winthrop was narrowly defeated; his lukewarmness in slavery matters had gained him the ill-will of Giddings and of the anti-slavery Whigs.

In the Thirty-first Congress Howell Cobb, of Georgia, succeeded to the Speakership, ${ }^{6 t}$ but he did 52. Democratic not follow in Mr. Winthrop's steps in speakers of his use of that office. One of the leadI849-1 855 . ing men of the South, the chief of the party which in the previous Congress had defended the administration of Polk, he was a man of ability and force. He made an excellent presiding officer, but his Speakership was aimed throughout at the advancement of Southern interests and the support of slavery. His committees reflected his ardent pro-slavery tendencies. Cobb was succeeded in I 85 I by Linn Boyd, a Kentuckian who carried on the work of his predecessor in as partisan a spirit, if not in as able a manner.

After the most protracted and exciting contest in

\footnotetext{
${ }^{63}$ See above, $\$ 36$.

4 See above, $\$ 36$.
} 
the history of the office, Nathaniel P. Banks, of Massachusetts, was chosen Speaker in $1856 .{ }^{65}$ Banks 53. Speaker- was one of the most popular as well ships of Banks as one of the most efficient Speakers. 1859].

His prompt and impartial decisions, his courteous manner and ever-ready tact, won for him the admiration of the House. Yet, although he occupied the chair during a stirring time, he left no marked impress upon the development of the Speaker's office, and in later life he strenuously denied that the Speaker possessed great political power. ${ }^{66}$ In spite of this, however, he was one of our famous Speakers, and his fitness for the position brought the House safely through some very delicate crises in the Kansas struggle.

Orr's administration (1857-59) was one of the most trying in our history. Violent scenes took place in the House of Representatives, especially during the struggle over the Lecompton constitution. Orr's sympathies were manifestly with the South: the very year after his Speakership he advocated a " prompt secession from the Union in the event of the election of a Black Republican to the presidency." 6 ?

In the critical condition of political affairs in 1859

54. Speakership of Pennington [1859-r86r]. the Republicans were unable to elect their first candidate for Speaker, Mr. Sherman. ${ }^{68}$ They looked around them ${ }^{\text {os }}$ See above, §37.

${ }^{80}$ This was the burden of a long conversation with the writer upon the subject in 1890 .

${ }^{67}$ Rhodes, History of the United States, II, 490.

${ }^{\circ 6}$ See above, $\$ 38$. 
simply for a man who could be elected, for a man of whom the Republicans need not be ashamed, yet whose political opinions should not be pronounced enough to frighten those whom it was necessary to attach. In Mr. Pennington, of New Jersey, they found a man just making his first appearance in the House, and without other experience in a legislative assembly than that gained by one term in the lower house of the New Jersey legislature. His qualifications for the office were some legal attainments, dignity of manner, equanimity of temper, and an undoubted integrity and impartiality. While personally entirely unobjectionable, he had the advantage of being free from the weight of a career. This absence of a record in a time of such great political excitement gained for him the high position to which his mediocre talents would never have entitled him.

Pennington made a respectable presiding officer: he was on the whole impartial, and his committees were acknowledged to be wise and just. He was, however, notably ignorant of the practice of the House. ${ }^{69}$ Cox says of him that he was perhaps " the most thoroughly unaccomplished man in parliamentary law who ever wielded the gavel." 70 At any rate he did not know enough of parliamentary law to manipulate it for his personal or for party advantage. He was not enough of a politician to

" There is a tradition which says that it was expounded to him by a superior young page, whose words of wisdom Mr. Pennington was obliged to repeat verbatim to the House.-Townsend, Washington In and Out, 155.

${ }^{70}$ Cox, Three Decades, 92. 
extract from the Speakership its political power, and he was too honest and upright to become the tool of the corrupt elements in the House. It cannot be said, on the other hand, that he had any definite conception of the Speakership as a parliamentary office, which he was endeavoring to carry out. He lacked the force necessary to give any direction to his office: ${ }^{i 1}$ he tried honestly to perform his duties as presiding officer, but he had no idea of the meaning of a "Speaker." When Pennington left the Speakership in I86I it was in exactly the same condition as when he had entered upon its duties.

From this brief survey of the Speakers before the Civil War may be gathered three generalizations. First, the Speakers were of several very 55. General tendencies of the Speakership to 186x.

different types: sccond-rate men who were yet the best leaders the House afforded, like Macon and Sedgwick and Andrew Stevenson; or tools in the hands of the real leaders, like John White; or real legislative leaders, strong, able men like Banks, Cobb, Clay, and Winthrop. Secondly, most of them used their office for political ends, so that the general character of the Speakership before the war was as decidedly political as since the war. But it must be noticed in the third place that there were exceptions to this rule, such as the administrations of

${ }^{\text {n }}$ We have had, however, no such Speakers as it has sometimes been the misfortune of the House of Commons to see in its presiding chair, so weak as to have no authority and defied again and again by the House.-Walpole, History of England, III, 479. 
Taylor and of Pennington; and these exceptions show that the popular conception of the Speakership did not yet accord with the real nature of the office.

Since I 860 there has been but one Speaker (Mr. Keifer) who was distinctly weak; every Speaker has systematically used his office as a political office; and no party or important group seriously questions that the Speaker is and should be a party leader. Owing to various causes the character of the government, and particularly of Congress, was materially changed during the Civil War; and the unmistakable and uninterrupted growth of the Speaker's political power, during and since that time, is one of the fruits of that fundamental change. In the previous struggle over slavery, from 1847 to $186 \mathrm{I}$, the clash of parties and factions had prevented the Speakers from exercising a decisive influence: even men like Cobb and Banks could not restrain the torrent of angry debate. During the war there was a large and eager majority, well marshalled, and the Speaker partook of its triumphs. The influence of party pressure at political crises must not be forgotten or its effects minimized: to each party it was a matter of such vital importance that the committees be constituted in its favor, that the contests to secure the maker of these committees were very serious: party needs were so urgent that it seems inevitable that the Speaker should have put his powers to the greatest service possible.

Grow, elected to the chair in IS6I, was one of 
the most eager champions of the anti-slavery movement." Holman said of him, "No man who was 56. Speakership ever Speaker more largely or more beneof Grow [r86z- ficially influenced the general course of 1863]. our legislation. He was a born leader among men." "s Grow was, so far as the writer's knowledge goes, the first Speaker to leave the chair and participate in the business of the House when the House was not in Committee of the Whole: February 21, 1862, he called Washburne to the chair and made a speech on the Homestead bill, a measure in which he was particularly interested. ${ }^{\text {" }}$ Quick and decided, Grow made a good presiding officer: with Thaddeus Stevens to lead on the floor he easily managed the House. His services were so well remembered that in 1894 he was triumphantly elected member-at-large from Pennsylvania, at the age of $7 \mathrm{I}$ years.

The political character of Colfax's Speakership was even more prominent. He was the first Speaker 57. Speakership to assume, at the very opening of the of Colfax [r863- House, the position of leader of the 1869].

House, by dictating to his followers the policy to be carried out. ${ }^{75}$ Colonel Forney said of him in connection with the performance of his duties as Speaker of the Thirty-eighth Congress, " He has been the embodiment of the war policy of

"In the previous Congress he had shown his zeal by knocking down Keith of South Carolina in a fisticuff encounter on the floor of the House.-Morse, Lincoln, I, 297.

"Cong. Record, 52 Cong. I Sess., 5 Ir.

"Cong. Globe, 37 Cong. 2 Sess., 909.

"See below, § I58. 
the government." 76 Just before the organization of the Thirty-ninth Congress (1865-67), Colfax addressed some of his friends upon the principles of reconstruction. "This was the first speech of any Congressman," says Moore, " taking issue with the President's 'policy,' and Mr. Johnson has always denounced it as the initiation of the Congressional policy which antagonized his. . . The next day Mr. Colfax called upon President Johnson; the President was not at all pleased with the speech, and was sorry that Mr. Colfax had not consulted with him before speaking to the assembling Congress and the country upon the important subject of reconstruction." $n$

A member of Congress under Colfax said of him: "He sometimes announces the passage of a bill as if it were the triumph of his own work, not as if he were merely reading the record of the House." In the debates of the House Colfax took an active part. On one occasion at least, he, as Grow had done, left the chair to engage in ordinary business when the House was not in Committee of the Whole:-April 8, I 864, Mr. Long, of Ohio, while the House was in committee, made a speech in favor of the recognition of the Southern Confederacy; the following day, immediately after the opening of the session, Mr. Speaker Colfax left the chair and moved the expulsion of Mr. Long. "I recognize," said he, "that there is a double duty incumbent upon me: first to the House of

\footnotetext{
"Moore, Life of Colfax, 178.

"Moore, Life of Colfax, 284.
} 
Representatives . . . to administer the duties of the chair and the rules of the House faithfully and impartially to the best of my ability and judgment. - . But I feel that I owe still another duty to the people of the ninth Congressional district of Indiana, who sent me here as their Representative to speak and act and vote in their stead. It is in conforming with this latter duty to those who cannot speak here for themselves, and who, I believe, would indorse the sentiment of this resolution, that I have felt it my duty to rise in my place as a member of Congress from the State of Indiana, and offer this resolution." is Mr. Colfax's position needs no further commentary. But it is interesting to notice that while the extraordinary spectacle of a Speaker leaving his chair to make a personal charge and to move the expulsion of a member was condemned by his adversaries, ${ }^{79}$ yet in the whole debate there is not the slightest hint of any objection to the mere action of a Speaker descending from his place to take part in the proceedings of the House. Colfax is believed to have modelled his Speakership after that of Clay. ${ }^{80}$ There are indeed some ${ }^{78}$ Cong. Globe, 38 Cong. I Sess., 1505-1546. The matter was not settled that day. When it came up afterwards Colfax always left the chair and gave it to Mr. Rollins.-Cong. Globe, 38 Cong. I Sess., $1533,1577,1618$. During the debate the resolution of expulsion was modified to one of censure and passed by a majority of eleven.-Cong. Globe, 38 Cong. I Sess., I634.

79 "I regret that he should for the first time have committed an act which must materially affect his usefulness hereafter in the discharge of his duties."-Fernando Wood, Cong. Globe, 38 Cong. I Sess., 1535 .

${ }^{80}$ Moore, Life of Colfax, 324. 
striking points of resemblance: Colfax made some attempt to become the legislative leader of the

58. Comparison nation; both openly expressed the inof colfax and tention of retaining all the rights of a clay. member. It happened, too, that Clay and Colfax possessed certain personal qualities in common; never perhaps, since Clay, had a Speaker equalled Colfax in that unfailing tact which is such a valuable possession for a presiding officer; Colfax, moreover, never neglected conventional justice and impartiality; he possessed also an easy temper, and kindly, genial manner; indeed, his suavity and forbearance in guiding the House were sometimes criticised as excessive; still while by his manner he avoided all odium, he kept the House in order and to its business.

No Speaker except Henry Clay has ever been so popular: elected three times to the chair, he resigned in 1869 only to assume the Vice-Presidency. During his second term he received the unusual compliment of a vote of thanks at the end of the first session (I866). The vote was probably passed because it had been an unusually difficult session, but it was also a recognition of satisfactory conduct during that stormy year. The resolution of thanks passed in I 869 was fuller and more elaborate than usual: it spoke of his "skill in parliamentary law, dignity and impartiality, promptness." In his farewell speech he states that no decision of his had ever been reversed. He left the chair amid the prolonged applause and enthusiastic cheering of both parties. 
The resemblance between the Speakership of Clay and of Colfax is, however, but superficial: while Colfax had something of Clay's charm of manner, he had none of his power. He was indeed a man of very moderate capacity. His knowledge of parliamentary law was so little that he is said to have been under the necessity of having a parliamentary companion to explain to him the mysteries of that difficult branch of knowledge. And while his political integrity was unquestioned, he had an easygoing nature which made him always prefer to go with the crowd. His manner was always the same, it is said; he came up from every difficulty smiling. But he lacked strength: he was constantly looking around for a little help or advice here or there. ${ }^{81}$ Whatever Colfax's ambitions may have been, therefore, his talents were not such as to enable him to lead the House of Representatives. And although the House under Colfax, as the House under Clay, came into conflict with the President, the resemblance is here again but superficial: while Clay induced the House, and indeed the whole Congress, to force a policy upon the President, the Thirtyninth Congress was already aroused to strong opposition to President Johnson, and would have worked out an organized resistance without a Speaker. If its success is to be attributed to any leaders, it must certainly be divided among several members of that famous Congress.

${ }^{-1}$ To use the words of an eminent member of Congress under Colfax, " He was this kind, "If your boat isn't full, I'll go along with you," " 
The power of the Speakership from 1869 to 1875 was due largely to the personal character and force of James G. Blaine. As a presiding 59. Speakership officer he had great skill: he decided
of James G. Blaine [r869- quickly, kept the House at work, 1875].

evinced an accurate knowledge of parliamentary law, and was in manner usually cool, dignified, and courteous. It was sometimes felt, to be sure, that he managed the minority rather too summarily, and it is certainly true that his energy in getting at his ends often swept aside all obstacles without ceremony. He was, nevertheless, one of the most popular of Speakers: from his friends he won an enthusiastic admiration, while those who disapproved the aims and character of his Speakership generally acknowledged his efficiency as a presiding officer. We cannot speak too emphatically, however, of the political character of his Speakership, and the influence it has had upon the recent development of the office.

A clever manipulator of the rules, Blaine was eminently successful in turning the ordinary parlia60. Blaine'a use mentary duties to party or to personal of parliament- use. In a short sketch of Blaine's ary powers.

political career, the author speaks of an " adroit manœuvre" to get a private telegram communicated to the House while he was Speaker pro tem.: some one asked to have a telegram from the Governor of Illinois read, and Blaine decided that he could not tell whether it was in order until he had heard it. ${ }^{82}$ Recognition was a favor sparingly ${ }^{82}$ J. B. Mansfield and D. M. Kelsey, Personal Sketches of Members of foth Congress, 9-10. 
and carefully granted. It has been said that $\mathrm{Mr}$. Blaine would bargain with men for recognition: ${ }^{83}$ "If you will make your resolution so and so, I will see that you have the floor;" many men preferred to "introduce bills stamped with Blaine's interference than to lose their bills altogether." This was, however, assuming unaccustomed power: the Speaker who can frame resolutions and alter bills has the House under strict discipline.

For the reiterated accusations that $\mathrm{Mr}$. Blaine constructed his committees for occult and discredit$\begin{array}{ll}\text { 6x. B1aine's } & \text { Bule purposes, no proof has been found. } \\ \text { committees. } & \text { Butler was, to be sure, placed at the }\end{array}$ head of the Judiciary committee in 1873 , and the Credit-Mobilierists given prominent positions. But a Speaker can do no better than his material allows: Blaine had to choose for his chairmen the leaders of the House, and there were not many men of high character among the leading members of those Congresses: if he did not construct the Civil Service committee so that a Civil Service bill should be reported, if in 1873 he balanced the committee on Banking and Currency between the inflationists and those who believed in a redeemable currency, he only followed the sentiment of the House. If Blaine's committees, however, were not so corrupt as some of his enemies assert, they were certainly constituted as far as possible to secure what he and the Republican party wished.

Blaine's controversy with Butler, moreover, shows little consciousness either of the dignity of his office ss Nation, XXVI, 226. 
or of any necessity for separating the chair even ostensibly from politics. February I6, I87 I, Butler, 62. Blalne's as chairman of the committee on Reconcontroversy struction, reported a bill ${ }^{84}$ agreed on with Butler.

by all the Republicans of that committee except Mr. Farnsworth. He was not able to present his bill, however, as the committee on Appropriations occupied all the time. On February 28, Butler was at last given the floor, and the Clerk at his direction began reading his bill to the House; but before the reading was finished the Speaker permitted the Clerk to be interrupted and gave the floor to Mr. Fernando Wood, of New York, who moved a suspension of the rules to pass a joint resolution to repeal the duty on coal, ${ }^{85}$ a measure to which the Speaker was favorable. Butler's bill thereby lost its last chance. Blaine afterwards ${ }^{86}$ justified his action on the ground that while the Clerk is reading, no one occupies the floor. If this be true it is yet easily seen that if Blaine had favored Butler's bill, it might have secured a hearing.

The next Congress met March 4, 1871. Butler was again prevented from getting in his bill. Meanwhile the Speaker drew up a resolution for the appointment of a committee to investigate the condition of the Southern States. March I5, he gave the floor to $\mathrm{Mr}$. Peters who presented the resolution, ${ }^{87}$ and

\footnotetext{
Cong. Globe, $4 \mathrm{r}$ Cong. 3 Sess., r $32 \mathrm{r}$.

- Cong. Globe, 4 I Cong. 3 Sess., I 76I-2.

* Cong. Globe, 41 Cong. 3 Sess., 126. March 16, 1871.

- Cong. Globe, 42 Cong. I Sess., Ir6.
} 
it was passed without debate, under the previous question. ${ }^{8}$ Butler at once wrote a letter denouncing the resolution as a trick, as a combination of the high-tariff Republicans with the Democrats, and declared that it was so framed that the committee could not report for a year. The next day the subject was brought up for consideration, and $\mathrm{Mr}$. Blaine descended from the chair to engage in a most undignified personal controversy with a member of the House. He declared Butler's letter " an insult to the Speaker of this House," and referred to its "misstatements," "mean inferences and meaner innuendoes." "Nobody regrets more sincerely than I do," said Mr. Blaine, " any occurrence which calls me to take the floor. . . Mr. Speaker, in old times it was the ordinary habit of the Speaker of the House of Representatives to take part in debate. That custom has fallen into disuse. For one, I am glad that it has. For one I approve of the conclusion that forbids it. The Speaker should, with consistent fidelity to his own party, be the impartial administrator of the rules of the House, and a constant participation in the discussion of members would take from him that appearance of impartiality which it is so important to maintain in the rulings of the Chair. But at the same time I despise and denounce the insolence of the gentleman from Massachusetts when he attempts to say that the Representative from the third district of the State of Maine has no right to frame a resolution; has no right to seek that under ${ }^{8}$ Cong. Globe, 42 Cong. I Sess., rr6-7. 
the rules that resolution shall be adopted; has no right to ask the judgment of the House upon that resolution. Why, even the insolence of the gentleman himself never reached that sublime height before, and that is the whole extent of my offending, that I wrote a resolution-that I took it to various gentlemen on this side of the House-that I said to the gentlemen on the other side of the House, - This is a resolution on which you cannot afford to filibuster; it is a resolution demanding a fair, impartial investigation, and under the rules I desire that this resolution may be offered, and my colleague (Mr. Peters) will offer it.' "' 89

Later, when Mr. Butler inquired ironically if he spoke for the House, as " by the ancient parliamentary law . . . one person shall be Speaker of the House, to speak for the House," Blaine replied that Colfax had also found it necessary to leave the chair to chastise the insolence of $\mathrm{Mr}$. Butler. Both these Speakers might have left a higher reputation for dignity had they never left the chair to attack a fellow-member or even to make a personal explanation.

It is unfortunate also for Mr. Blaine's reputation

* Cong. Record, 42 Cong. I Sess., 125. The extract is quoted in full in order to show the language thought suitable by a Speaker of the House of Representatives. Butler's language against the Speaker was more vehement. The following rhyme is a specimen :

For ways that are dark

And tricks that are vain

I name Speaker

And that I rise to explain.

-Cong. Record, 42 Cong. I Sess., I26. 
as Speaker that so much public attention should have been called to some decisions in which he 63. Little Rock was supposed to have a personal interaffair.

est. His railroad transactions during his several terms of office are suspicious, and suggest that he was allowed to enter certain corporations at a great advantage in return for services rendered in the chair of the House. Still there is only one incident of which we have any accurate information. Mr. Blaine-was anxious to be admitted into the Little Rock Railroad, and promised that he " would not be a deadhead in the enterprise." ${ }^{0}$ When the bill renewing the land grant to the State of Arkansas for the Little Rock Railroad was brought up, an attempt was made to add an amendment to which it was well known the Senate objected, and which would therefore defeat the bill. The Little Rock men were in despair and appealed to Blaine for aid. Blaine sent his page to General Logan, who was opposed to the amendment, to suggest that he make the point of order that the amendment was " not germane." 91 The point of order was at once made by General Logan and sustained by Speaker Blaine ${ }^{92}$ in a ruling which illustrates his incisive manner and his determination that the bill be not impeded. "The Chair sustains the point of order for two reasons. It is expressly

${ }^{\infty}$ From one of the Mulligan letters dated June 29, I869, and read in the House June 5, 1876.-Cong. Record, 44 Cong. I Sess., 3606.

${ }^{11}$ From Blaine's letter to Mr. Fisher, October 4, 1869.-Cong. Record, 44 Cong. I Sess., 3606.

"Cong. Globe, 4I Cong. I Sess., 702. 
prohibited by the rule that when a land grant is under consideration another grant to a different company shall be entertained. This is not a specific land grant, but it does give away the public land of the United States so far as to give the right of way. Again, by the rules, no proposition upon a subject different from that under consideration can be admitted under color of an amendment." 93 In the decision itself there was nothing improper. It was true, as Mr. Blaine said, that he would have made the same ruling in any case had the point of order been raised. His zeal in calling General Logan's attention to the point of order, however, seems significant in the light of his later request for a share in the Little Rock Railroad on terms not given other people; he expressly called attention to this ruling in the House of Representatives as putting that railroad under great obligations to him. But whether or not Blaine used his office for private gain, he certainly used it for party interests and for the advancement of his own political ends.

Blaine was followed by Kerr, a man of high personal character, who performed the duties of the 64. Speakership Speakership with dignity and impartialof Kerr [r875- ity. His election in 1875 is peculiarly $1876]$.

interesting. In the Forty-fourth Congress was the first Democratic House that had assembled since the beginning of the Civil War. After fifteen years of Republican domination the Democrats were at last to take their turn at legislation. It was a critical moment. Few Congresses "3ong. Globe, 4I Cong. I Sess., r 702. 
have been watched with such eagerness for some sign of the character of their legislation. With the eyes of the nation upon them the Democrats felt that they must exercise unusual care in choosing a Speaker whose principles and character would indicate to a large extent what Democratic control was to mean. Kerr and Randall were the leading candidates; Randall was, by experience and aggressiveness, the leader of the Democratic party in the House, but there were uncomfortable things whispered about him, while Kerr stood above suspicion. Kerr was indeed a devoted adherent of the Democratic party, which he had long served faithfully; but his election was probably chiefly due to the fact that it would be an announcement to the country that the better elements of the Democratic party were to preponderate in the control of national affairs.

Kerr died in office, and at the second session Randall was chosen without Democratic opposi65. Speakership tion. Randall was a good parliamentaof $R$ anda11 rian, presided with firmness and discre[x876-188x]. tion, and on one occasion at least won by his fairness the respect of all his political enemies. In 1877 there was an attempt made to prevent Hayes's election in the House by the parliamentary tactics of obstruction. Mr. Randall was opposed to Hayes. It was at that time considered that under the rules obstruction could not be prevented. Probably no one would have held that Randall had neglected his duty if he had allowed motions to take their course, and the obstructionists 
to secure Hayes's defeat. But Mr. Randall considered it his duty to obey the Electoral Commission act just passed, and to stop obstruction on the Presidential election. He conscientiously performed this duty, therefore, in spite of his individual preferences and the fierce assaults of his political friends. ${ }^{94}$

An accusation was later brought against Randall of using his office for personal gain. February 27, 1879, the charge was made in the House that through the influence of Randall and others, two illegal appropriation warrants had been signed for money to continue the operations of the Engraving and Printing departmient, " which was directly in the interest of Samuel J. Randall, who is a large stockholder in the paper mill which is alone authorized to supply the Bureau of Engraving and Printing with paper." 95 A committee was appointed to inquire into the matter, and Randall was exonerated from the charge. ${ }^{96}$ Mr. Blaine said of Randall as Speaker, "He never neglects his public duties and never forgets the interests of the Democratic party." 97

It is true that Randall made no more effort than 66. Difference his predecessor to change the political betweenSpeak- tone of the Speakership. Like Blaine, crships of too, he was accused of an intimate Randall. acquaintance with the "gentlemen of the lobby." But while Blaine's first object was to

94 Cong. Record, 44 Cong. 2 Sess., 2030-2068.

* House Journal, 45 Cong. 3 Sess., 54I.

${ }^{\circ}$ House Journal, 45 Cong. 3 Sess., $671-674$.

" Blaine, Twenty Years of Congress, II, 566. 
make himself personally popular, and thus to keep himself before the country, Randall aimed directly at increasing the influence of the Speakership and making it a governing power. This purpose he carried out systematically: he first brought about a change in the rules, and then by his administration of these rules greatly increased the authority of the Chair. His successors, Carlisle, Reed, and Crisp, have had the same end in view and have done more than any recent incumbents towards accomplishing that end, but Randall appears to be the first Speaker who aimed directly at power through alteration of the rules. His opinion of the importance of the Speakership was on one occasion expressed in the House: "Soon after I entered this House," he said, . . " I came to consider that that office [the Speakership] . . . was the highest office within the reach of an American citizen; that it was a grand official station, great in the honors which it conferred and still greater in the ability it gave to impress upon our history and legislation the stamp of truth, fairness, justice, and right. . . When it fell to my fortune to occupy the Speaker's chair, I realized how true was my idea of the position. . . ." 98

Mr. Randall's Speakership was terminated by the failure of his party to keep its majority in the 67. Speakership election of 1880 . When Congress of keifer [ $1881-$ assembled in 1881 the House chose 1883.]

Mr. Keifer, of Ohio, as Speaker: Mr. Blaine was no longer in the House; Mr. Reed ${ }^{\infty}$ Cong. Record, 52 Cong. I Sess., 5 II. 
was serving his second term, but had not then become prominent in his party; there seemed to be nothing against Keifer, and the Republicans thought it was the best they could do. The marked feature of Keifer's administration was its partisan character; but his partisanship was rather that of weakness than of determined aggression. When he entered upon his office it was generally thought that he possessed moderate ability, impartiality, and integrity of character; it was soon found that he had neither the ability nor the fairness necessary for the Speakership. To construct the committees of the House of Representatives with regard to their effect on legislation as a whole, to construct them with some regard to harmony and coherence, requires unusual skill. Mr. Keifer seems to have looked only at the effect of each isolated committee, and since he was very susceptible to influence, one faction controlled him at one time, another at another. The worst of his appointments was the committee on Elections, which consisted of eleven Republicans and two Democrats. His committees ${ }^{88 \mathrm{z}}$ seem to suggest also

"The Nation said of Mr. Keifer's committees: "While omitting to make several assignments demanded by every consideration of propriety as well as of public interest, he has made others of a decidedly improper character. The composition of the Ways and Means Committee, and of the committees on the Navy and on Naval Expenditures are of that kind, likewise the treatment of Mr. Kasson, and of some prominent members of the minority, who, in a long course of public service, had acquired certain specific knowledge and experience which would have been of great value in the discussion of the most important questions coming before Congress."-Nation, XXXIV, 21, (Jan. 12, 1882). 
that he had not been above the influence of the lobby.

But Mr. Keifer's inadequacy, already hinted at in his make-up of the committees, was emphasized ten-fold by his conduct in the chair. There he was weak and undignified, and his partisan rulings soon won him the contempt of Republicans as well as of Democrats. Mr. Keifer had perhaps no different aim than other Speakers, to impose his own will on the House of Representatives; but he failed because he was not strong enough to carry out such a scheme, and because he was not keen enough to see the limits to which a Speaker can use political power without being denounced as a partisan. Keifer was, moreover, accused of using his position to advance the interests of his relatives: the New York Tribune says that when elected Speaker he appointed one nephew " Clerk to the Speaker" at a salary of $\$ 1,600$, another " Clerk to the Speaker's table" at a salary of $\$ \mathrm{r}, 400$, and in June made his son private secretary to the Speaker at a salary of $\$ 1,800 . .^{99}$ His removal of a stenographer to make room for a nephew excited much indignation. ${ }^{100}$ Keifer's use of his office was, however, quickly punished. In the next Congress, to be sure, he received the complimentary nomination of the minority; but whereas this usually implies the leadership of the minority, Keifer was at once forsaken by his political associates. Abandoned by his party his political career was necessarity at an end.

"New York Tribune, Mar. 6, I883.

${ }^{100}$ New York Tribune, Mar. 6, 1883. 
Carlisle's term is of the greatest interest because he boldly laid down in regard to the Speakership 68. Speakership a principle which, if already gaining of car1isie ground, had never been asserted so [1883-1889]. openly as it was throughout his administration: It was the principle that the powers of the Chair should be used, not in a spirit of balancing favors to majority and minority, not even in a spirit of obedience to the dictates of the majority, but in accordance with the Speaker's individual judgment. He considered it the Speaker's duty to be the leader of Congress, to have a definite legislative policy, and to take every means in his power to secure the accomplishment of that policy. He himself shirked neither the duty nor the responsibility: again and again he opposed the will of a large majority of the House by refusing recognition to members who wished to take up important business; his committees also, while fair and able, represented Carlisle's views more closely than any one's else. By every other means which his office afforded, he sought, entirely regardless of his position as chairman, to impose his will on the House and to be the real source of the legislation of the United States. In 1885 the Nation charged him with " deliberately using his official position to postpone action on the appropriation bills till the last moment, while expressing a quiet confidence that there would be no extra session, and then sending them to the Senate, the only place where there is any discussion, so late as to render discussion impossible, and to force a settlement in secret 
conference committees." 101 And the New York Tribune speaks of a petition, signed by all the Republican members of the House, praying Mr. Speaker Carlisle, as chairman of the committee on Rules, to call a meeting of that committee and make a report. ${ }^{102}$ But the petition was completely ignored: the committee on Rules did not report through the entire first session of the Fiftieth Congress.

Yet Carlisle's course in the chair, whether deserving approval or blame, must not be considered as an underhand attempt to get power for himself. He was only carrying out his honest conception of the Speakership. It was not that he followed his own aims in spite of the old theory: he really wished to establish a new theory. Carlisle was one of the strongest of Speakers: a good parliamentarian, with power of command and force of purpose, he ruled the House for six years. Mr. Carlisle had not only the manner which wins quick popularity, but he had the ability which gains recognition and appreciation. He left the chair amid the enthusiastic approval of the House.

The national election of 1888 for the first time since 1875 gave the Republicans control of the 69. Speakership Presidency, Senate, and House of Repof Reed [r889- resentatives. It was an evidence of a 1895].

purpose to use this advantage that a Speaker was chosen who had already shown a strong and energetic character. Mr. Reed accepted the increased powers of the Speakership and added to

${ }^{101}$ Nation, XL, 218-219. (March 12, 1885.)

${ }^{202}$ New York Tribune, Feb. 5, 1890. 
them even new attributes. The methods by which he prevented obstruction will be considered in a later chapter. ${ }^{103} \mathrm{He}$ succeeded in gaining control of a House which showed signs in its beginning of extraordinary turbulence. Reed as well as Carlisle, moreover, insisted on his position of actual leader of the House. His attitude to the Republican party was the same as Carlisle's attitude toward the Democratic party: he sought not to represent his party, but to impose his own ideas upon it. A Republican member, Mr. Struble, of Iowa, is said to have made a speech during Reed's administration in complaint of "his sitting in the chair with his feet on the neck of the Republican party." A second marked feature of the dominations of both these men was the tendency to concentration of power. An interesting example is the constitution of their respective committees on Rules: in the Fiftieth Congress Carlisle, ${ }^{104}$ and in the Fifty-first Congress Reed, ${ }^{105}$ appointed the chairman of the Ways and Means and the chairman of Appropriations, together with the Speaker, as the majority members of the committee on Rules. The three men occupying the most powerful places in the House were thus associated, and formed a " steering committee" by whose insistence the McKinley tariff of 1890 was forced through. They took the responsibility of legislation.

The election of Crisp was not only the most ex-

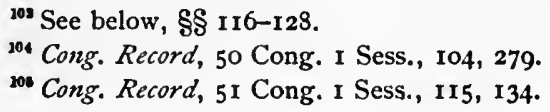


citing for many years on account of the prolonged balloting in the caucus, but for various reasons was 70. Speakership very interesting. The split in the cauof crisp [r8gs- cus did not so much show a political dis895].

vision in the Democratic party as a disagreement in regard to who would make the best leader. If Carlisle had been in the House there would not have been the least delay. Carlisle is a born leader: men love to follow him. The reason why Judge Crisp seemed to many outside the House almost unknown at the time of his election, was that the Democratic chiefs had been completely overshadowed by Mr. Carlisle; he was absolute leader of the House and no one else had a chance. Now, the question as to his successor had to be decided. While Mills was the tariff leader of the Fifty-first Congress, Crisp was considered " the political leader;" that is, he had stood forward on general questions, and particularly in the matters - arising out of Mr. Reed's decisions. The question could not be decided by the political principles of the two men, for Crisp was as strong a tariff man as Mills, and Mills, as has been proved by his subsequent action in the Senate, as strong a free-silver man as Crisp. But while Mr. Mills was a warm-tempered, impulsive man who had not always kept his self-control, Judge Crisp had a calm, judicial manner and had preserved his dignity through many trying circumstances. By the end of the Fifty-first Congress many of the old members had made up their minds that they would prefer to follow Crisp, and that he would make a better Speaker. Randall had 
told them that Crisp was a man upon whom they could rely. In the spring of 1891 , then, there was not much thought of Mills for the Speakership: indeed, during that summer Judge Crisp made a speech in Faneuil Hall, Boston, at the end of which three cheers were given for the Speaker of the Fifty-second Congress. But then came the new members who did not know Mills well, and it was they who got up the theory of Mills as the " logical candidate:" their claim was that the leader of the tariff-reform wing of the party should be given the chair in a House elected on the issue of the tariff reform. There is a tremendous incentive for the new members to elect their Speaker: if they do not, they stand at the end of the line for committee places, and thus lose their only chance of getting any part of the work or the spoils of the House. The new members worked hard, therefore, to elect Mr. Mills. Mr. Springer, of Illinois, was also a candidate and received a fair number of votes. ${ }^{106}$ Compromise was impossible. In the course of the negotiation it is reported that Hayes, of Iowa, went to Springer and said, "Springer, withdraw in favor of Mills and he'll be Speaker and you'll be leader of the House. This is the greatest opportunity of your life." "Hayes," said Springer quickly, "if Mills will withdraw in my favor I'll be Speaker and he'll be the leader of the House." After thirty votes had been taken in the Democratic caucus a majority was finally obtained for Judge Crisp.

${ }^{106} \mathrm{Mr}$. McMillin and Mr. Hatch also received votes on the first ballots. 
Speaker Crisp has proved fairly well-fitted for the office. He has been the actual leader of the House and may be considered responsible for the legislation of the Fifty-second and Fifty-third Congresses. He has worked for his party in every way, has never hesitated to make parliamentary decisions in its favor when possible, and has in no way fallen below his immediate predecessors in giving a political character to his office. If a political Speaker using his parliamentary duties in the interest of his party is to be denounced, Mr. Crisp will have to share with all recent Speakers in that denunciation. That he has completely satisfied his party is proved by the fact that when in the winter of $1894-5$ he was offered the senatorship of Georgia, a large number of the Democratic party signed a petition begging him not to leave the House, and Mr. Crisp was persuaded to give up the senatorship for the remaining three or four months of Congress. It is said that many of the Democrats who did not sign this request would have done so had they not known that the Senate had been the ambition of $\mathrm{Mr}$. Crisp's life.

It is worthy of special remark that each of the three most recent Speakers has gained his chief 7r. Recent power in a different way. Mr. Carlisle Speakers com- assumed the absolute right of recognipared.

tion. At once arose the cry which warned future Speakers against at least such an open use of what was called an arbitrary power. Mr. Reed claimed the right to prevent the dilatory tactics of a minority. But brave would have been 
the man who should have dared to follow in $\mathrm{Mr}$. Reed's footsteps. Under Judge Crisp, however, the power of the committee on Rules was greatly increased. Immediately followed loud denunciation of such a committee and proposals to lessen its authority. If Carlisle had asserted a power, Reed had insisted upon the same, and Crisp had continued it, the inevitableness of the development of the Speakership would now be more apparent. Yet it is really a much more suggestive fact that when popular opinion takes from the Speaker one method of control he immediately finds another. If no Speaker has yet seized upon the sum of all the gains made by his predecessors, nearly every one since the Civil War has continued by some device to assert his mastery. The drift of power to the Speakership is as clear as the fact that strong and forcible Speakers have greatly affected the development of that power. 


\section{CHAPTER IV.}

THE SPEAKER'S PARLIAMENTARY PREROGATIVES.

$\mathrm{N}$ order to trace the development of the Speak1 er's power we must now turn to a considera72. Sources of tion of the parliamentary and political the speaker's privileges of the Speakership. The powers.

parliamentary powers and duties of the Chair are derived from four sources: the Constitution and laws of the United States; the rules of the House $;^{1}$ the practice of Speakers, especially as embodied in previous decisions; and general parliamentary law as established by English ${ }^{2}$ and by American practice, especially that of the State legislatures. It has been uniformly held that the Chair is bound to take notice of a requirement of the Constitution or of a provision of law mandatory in its character before and above the rules. The most notable of recent decisions to this effect was that of $\mathrm{Mr}$.

'A special rule requires that the Speaker shall be governed in the discharge of his duties both by the rules of the House of Representatives and, as far as it is applicable, and not inconsistent with the rules, Jefferson's Manual of Parliamentary Practice.-Appendix D, Rule XLIV ; adopted Sept. I5, 1837.

'Since the Speakership of Mr. Winthrop, I8.47-49, May's Parliamentary Practice has been kept on the Speaker's table as a guide and authority on all difficult points of parliamentary administration. - North American Review, CLI, I02. Lex Parliamentaria was for many years referred to as an authority. See Debates. 
Speaker Randall in $187 .^{3}$ In that year there was some difficulty in the election of President and Vice-President. The ordinary modes of procedure being insufficient, Congress was obliged to pass the Electoral Commission act. But there was an attempt made to prevent Hayes's election by a systematic course of obstruction. Mr. Randall, therefore, declined to entertain points of order, refused even to entertain appeals on certain propositions, holding that the terms of the Electoral Commission act were in certain respects mandatory on the Chair as against a rule of the House. He overrode the rules of the House on the ground that he was executing a law of the land in the execution of which time was an essential element. In a later Congress he justified his action with the words: "To me the law was higher than the rules when the law came in conflict with the rules." 4

The Speaker, elected by the House, is responsible to the House. He may at any time be removed 73. Responsi- from his position and another Speaker bility of the elected. ${ }^{5}$ In the House of Commons Speaker.

it has been necessary to resort to this expedient in two instances: in 1673 the conduct of Sir Edward Seymour was complained of and a motion made for his removal; ${ }^{6}$ the motion was,

'See Cong. Record, 44 Cong. 2 Sess., 2030-2068. For a similar decision by Mr. Carlisle, see Cong. Record, 49 Cong. I Sess., 7437.

- Cong. Record, 47 Cong. I Sess., 4308.

- There is no rule upon the removal of the Speaker. Jefferson's Manual provides, "A Speaker may be removed at the will of the House and a Speaker pro tem. appointed." §IX.

- Parliamentary History, IV, 591. 
however, rejected; but in 1694 Sir John Trevor, having been proved guilty of a crime against the House, ${ }^{7}$ resigned his position and later was formally expelled. ${ }^{8}$ The question of the removal of a Speaker has never come up in the House of Representatives. An assembly may, by another form of control, pass against its presiding officer a vote of censure. While votes censuring the Speaker have not been unknown in the House of Commons, ${ }^{9}$ a vote of censure has never been passed against the Speaker of the House of Representatives, and in only two instances has such a vote been moved. Sedgwick in the Sixth Congress expelled from the gallery the editor of the National Intelligencer, who had imputed partiality to Mr. Sedgwick in a decision on a question of order: a vote of censure was moved, it being urged that the Speaker can expel from the gallery only on the ground of disorderly conduct; but the motion was decided out of order and so did not come to a vote. ${ }^{10}$ In 1832 Mr. Stanberry, of Ohio, accused Andrew Stevenson of shaping his course as the presiding officer of the House with a vicw to obtaining favors from the President, and a motion was made for his censure Still a third check upon the Speaker is his responsibility to his party: it may depose him from the rank of leader and refuse him all recognition after the expiration of his term of office. ${ }^{11}$

${ }^{7}$ See below, $\$ 80$.

"Parliamentary History, V, 906-910 [1694].

- On one occasion, in the session of $I 768-9$, the words of the Speaker were taken down.-Massey, IIistory of England, I, 549.

${ }^{10}$ Hildreth, History of the United States, V, 4II-4I2.

1 See above, $\$ 67$. 
The Speaker is helped in the performance of his duties by the consideration which parliamentary

74. Respect due the Speaker. law and practice give to a chairman: ${ }^{12}$ when a member desires to say anything to the House he must always first rise and address himself to Mr. Speaker ; ${ }^{13}$ personal controversy with the Chair is never allowed. When in the Fifty-first Congress Mr. Reed decided that a question submitted to him by Mr. Pierce of Tennessee was not a question of privilege, Mr. Mills indignantly attempted to argue that the Tennessee member was in order; but Reed promptly silenced him with the reply that " the Chair does not wish to have any personal controversy with the gentleman from Texas and thinks that if the gentleman from Texas will reflect he will see the impropriety." 14

It is expected that whenever the Speaker addresses the House respectful attention shall be given him. ${ }^{15}$ The rules require that while the Speaker is putting a question or addressing the House, no one is to walk out of or across the hall, or, when a member is speaking, pass between him and the Chair. ${ }^{16}$ This rule is, however, constantly violated. An old rule required further that when the Speaker was addressing the House no member

${ }^{12}$ In the early years of the House of Commons controversy with the Speaker was frequent.

${ }^{13}$ Appendix D, Rule XIV, I; adopted April 7, 1789. Manual, §I7.

"Cong. Record, 5 I Cong. I Sess., 3976.

${ }^{15}$ Hatseil, Precedents, II, 23I, 239.

${ }^{16}$ Appendix D, Rule IV, 7; adopted April 7, 1789. Jefferson, Manual, § I7. 
should entertain private discourse or read any printed book or paper $;{ }^{17}$ also that when the House adjourned the members should keep their seats until the Spcaker had left the hall. ${ }^{18}$ And Jefferson tells us that when the Speaker is seated in his chair, every member should sit in his place. ${ }^{19}$ Although such rules might add much to the dignity of the House, their enforcement is clearly impracticable. Still the Speaker is not merely in theory, but in practice, treated with courtesy. Whoever the man may be that occupies the chair, the office carries with it a sense of dignity and a demand for respectful treatment which the members feel and with which they willingly comply. ${ }^{20}$

Before proceeding to those high parliamentary functions which make the Speaker powerful, it may 75. Opens and be well to enumerate certain minor closes sittings duties. The first requirement of this of the House. presiding officer, under the rules, is to open the sittings of each day by taking the chair at the hour to which the House shall have adjourned, and calling the members to order. ${ }^{21}$ It is the Speaker also who closes the sitting by an-

${ }^{17}$ Annals of Congress, I Cong. I Sess., 98-99.

${ }^{18}$ Annals of Cong., I Cong. I Sess., 98-99. Dropped from the rules March 14, 1794 .

19 Manual, § I7.

${ }^{20}$ Few men, except John Quincy Adams, have openly defied the Speaker. Mr. Adams's attitude may be seen from the following quotation, "The Speaker said again I could not debate the previous question; but I did not permit myself to be disconcerted by these interruptions."-Adams, Memoirs, VIII, 495.

${ }^{21}$ Appendix D, Rule I, I; adopted April 7, I789. 
nouncing the House adjourned: ${ }^{22}$ he makes this announcement either after a specific motion to that effect has been carried, or when the hour has arrived which has been previously agreed upon for its adjournment; he declares the House adjourned without action of the House at twelve o'clock of March $4^{\text {th }}$ of each alternate year, according to the clock over the Speaker's desk; for at that time the last session of Congress terminates; ${ }^{23}$ whenever the House is adjourning to a day certain, the Speaker mentions the day. $\mathrm{He}$ also upon motion declares the House in recess, stating the hour agreed upon for reassembling. The danger of allowing the Speaker any independent power over adjournment is illustrated by the history of the House of Commons. ${ }^{24}$

The most obvious function of a Speaker is that which the name implies, to act as mouthpiece and 76. Acts as representative of the House. ${ }^{25}$ Whenmouth piece ever the House wishes to express itself, and representa-
tive of the whenever it wishes to stamp its authorHouse. ity upon anything, whenever, in short, it is necessary for it to act in its collective capacity, 22 "If a question is put for adjournment it is no adjournment until the Speaker pronounces it." -5 Grey ${ }^{3} 37$. Jefferson, Manual, $\$ 50$. ${ }^{23}$ See ruling of Mr. Randall.-House Journal, 46 Cong. 3 Sess., 60-2.

${ }^{24}$ See Cobbett, Parliamentary History, IV, 898.

${ }^{25}$ The name of Speaker was given to the presiding officer of the House of Commons because his chief duty was to "speak" for the Commons. The name Chairman or "the Chair" arose in early times when the presiding officers of assemblies were alone provided with chairs. The members sat on benches, but it was necessary for the moderator to sit apart. 
it does so through its presiding officer. If the House has occasion to receive any one in the hall of Representatives, ${ }^{26}$ to extend its thanks, ${ }^{27}$ to administer censure, to receive messages, ${ }^{28}$ to receive and answer invitations, ${ }^{29}$ or to be represented at any public ceremony, ${ }^{30}$ it accomplishes its will through the Speaker. He informs the Governor of the State when a vacancy in representation occurs by a member's resignation or death. ${ }^{31} \mathrm{He}$ receives and announces all messages and communications from the other branches of the government. Estimates of appropriations and all communications from the executive departments, intended for the consideration of any committee of the House, are addressed to the Speaker and by him referred. In the early years of the government, when Washington read the presidential address to the assembled Congress, the reply of the House was delivered by the Speaker at the head of the Representatives waiting upon the President. ${ }^{22}$

When directed, the Speaker issues his warrant for the arrest of offenders, for the summoning of witnesses,,$^{33}$ or for the execution of any orders of

${ }^{96}$ House Journal, 40 Cong. 2 Sess., 823. Speaker addresses Chinese Embassy.

${ }^{27}$ House Journal, 6 Cong. I Sess., I9.

${ }^{28}$ House Journal, 7 Cong. 2 Sess., 107, 182.

${ }^{90}$ House Journal, 40 Cong. 2 Sess., 6r 7.

"House Journal, 46 Cong. 2 Sess., 1426.

"House Journal, 6 Cong. 2 Sess., 70, 87.

"Annals of Congress, I Cong. 3 Sess., 1845-6.

"Appendix D, Rule I, 4 . See House Journal, 4 Cong. I Sess., 58 ; House Journal, 44 Cong. I Sess., 588. The Speaker issues a 
the House which require the sanction of a legal form. When the warrant has been executed and returned, he reports the proceedings which have taken place under it. When the House is engaged in judicial business it is the Speaker who conducts the proceedings, administers the oath, ${ }^{34}$ puts the questions to witnesses, and pronounces the sentence or judgment. ${ }^{35}$ If the sentence includes a reprimand it is he who delivers it. ${ }^{96}$ When a witness fails to testify it becomes the duty of the Speaker to certify the fact, under the seal of the House, to the district attorney for the District of Columbia. ${ }^{37}$

All orders of the House are carried out by the Speaker. He, moreover, directs all proceedings in the House, as, for instance, the selection of seats. ${ }^{38}$ He has charge of the printing of the House, of changes in the hall of Representatives or in any part of the Capitol which belongs to them, and the appointment of most of the employees of the House. The appointment and the removal, for cause, of the official reporters, including the stenographers of committees, and the manner and execution of their duties, is vested in the Speaker. ${ }^{39}$ The Speaker

warrant to the Sergeant-at-Arms to bring absentees to the bar of the House.-House Journal, 44 Cong. I Sess., 1400.

"Appendix E, Revised Statutes, § ror.

"See House Journal, 28 Cong. 2 Sess., 224, 6 ; Annals of Cong., 15 Cong. I Sess., 608-9.

"See House Journal, 4 Cong. I Sess,, 85; House Journal, 15 Cong. I Sess., 154 ; House Journal, 22 Cong. I Sess., 590.

${ }^{37}$ Appendix E, Revised Statutes, § 104.

"Cong. Record, 52 Cong. I Sess., 116.

"Appendix D, Rule XXXVI, 6 ; Appendix E, Revised Statutes, 
with the President of the Senate establishes regulations for the library. ${ }^{40}$

The Speaker authenticates by his signature, when necessary, all acts, orders, and proceedings of the 77. Authenti- House; he therefore stands responsicates docu. ble for the assurance that such acts ments.

and orders have been passed in a proper and constitutional manner. $\mathrm{He}$ is required, moreover, to examine and approve the Journal, and to cause it to be read each day. ${ }^{41}$ Notwithstanding the heat of party feeling Speakers have seldom been charged with the serious offence of tampering with the Journal; but in the Twenty-seventh Congress Mr. White was accused of having made a misrepresentation in the Journal in order to place a doubtful decision in a better light. The matter was laid on the table by a party vote, but the evidence seems to sustain the charge. ${ }^{42}$ In the Thirty-first Congress Mr. Preston King charged the Speaker, Mr. Howell Cobb, with mutilation of the Journal, ${ }^{43}$ but the committee of investigation decided that the alteration was a correction, and not a mutilation. ${ }^{4}$

$\$ 54$. "For cause" inserted in the second session of the 45th Congress. For full account of this rule see Smith's Digest, 5I Cong., 507-8. For examples of reporters expelled by the Speaker see House Journal, 29 Cong. I Sess., 223. House Journal, 29 Cong. 2 Sess., 330. House Journal, 48 Cong. x Sess., 444-5. See also above, $\$ 67$.

${ }^{40}$ Barclay, Rules and Digest, ro3.

${ }^{1}$ Appendix D, Rule I, I; adopted April 7, 1789. The daily record of the House of Commons is signed by the Speaker.-Bradlaugh, House of Commons, 4.

${ }^{2}$ Cong. Globe, 27 Cong. I Sess., 226-7.

"House Journal, 3r Cong. 1 Sess., 7r3.

"House Journal, 3r Cong. I Sess., 738-9. 
Mr. Reed, whose opponents charged him with various parliamentary offences, was also accused of falsifying the Journal by counting a quorum. ${ }^{45}$

By the rule of March 29, 1842 , petitions and memorials were made subject to the control and direction of the Speaker: if any petition or memorial was presented which, in his judgment, was excluded by the rules, it was to be returned to the member from whom it had been received. At present, however, he has no further control over such documents than to see if they are of a proper nature, and then to refer them to the appropriate committee. ${ }^{46}$

The Speaker has now little to do with the financial arrangements of the House, except that the sureties of the bond given by the Sergeant-at-Arms for the faithful disbursement of all money entrusted to him must be approved by the Speaker. ${ }^{47}$ When it was pointed out in the Fifty-first Congress that the bond of the late Sergeant-at-Arms was worth nothing, as it did not contain certain specified conditions, Mr. Carlisle was at once accused of negligence in accepting it; but he was freed from all censure when attention was called to the fact that the bond was in the form accepted by his predecessors, and that he had approved it perfunctorily. ${ }^{48}$ Furthermore the salary and accounts for travelling expenses of representatives and delegates must be certified by the Speaker. ${ }^{49}$ At one time he had the

"S Cong. Record, 5I Cong. I Sess., I023.

- Appendix D, Rule XXII, 3 ; adopted I880.

${ }^{47}$ Appendix D, Rule IV, 3 ; adopted April 4, I838.

"Cong. Record, 5 I Cong. I Sess., 529-3r.

19 Appendix E, Revised Statutes, $\$ 47$. 
more arduous duty of paying members, who might call upon him at any time for irregular amounts. Thus the Speaker performs numerous minor duties, and represents the House in its powers, its proceedings, and its dignity.

It is a necessary duty of all presiding officers to announce the business before the House in the order in 78. Announces which it is to be acted upon. As the the order of members of the House of Commons in business.

the early Parliaments called confusedly for the propositions which they wished to have brought forward, ${ }^{50}$ the Speaker must have had some influence in the determination of the succession of debatable matters. As late as 1601 a suggestion from a member of the Commons that the Speaker appoint the order in which the bills should be read, was met with hisses by the House. ${ }^{51}$ The Commons have long since established definite rules on this subject. A settled order of business, Jefferson tells us, is necessary, among other excellent reasons, for the "government of the presiding officer." In accordance with this theory and with English practice the House of Representatives has carefully provided by its rules for the priority and the succession of motions, and the Speaker has few

${ }^{80}$ Hallam, History of England, I, 193, note. Before 1822 the rules provided what motions might be received during debate, but not their order of precedence. It was usually left to the Speaker's discretion. Now, however, the order of precedence is definitely fixed by the rules of the House.

${ }^{\text {"S }}$ Some foreign Presidents fix the order of the day for the next sitting.-Dickinson, Procedure of Foreign Parliaments, 93, 99, 107. 115, I19. 120 . 
opportunities to influence from the chair the order in which business shall be considered.

Another necessary and purely parliamentary duty is the obligation of the Chair to put to vote all motions and propositions which are in 79. States the order. ${ }^{52}$ This is an imperative duty of
question. all presiding officers. ${ }^{53}$ When in 1629 the Speaker of the House of Commons refused to put a question, his conduct was noticed and reproved in the next Parliament, eleven years later. ${ }^{5}$

In the English Parliament the Speaker puts even those questions which concern him personally. In 8o. Does not put questions in which he is personally inI694 it was found that Sir John Trevor had been using the Speakership to terested.

enrich himself: he was charged with having received 1,000 guineas from the corporation of the city of London for expediting a local bill, and he was obliged to stand and himself put the question that he had been guilty of a high crime and misdemeanor; moreover, on the follow-

62 Appendix D, Rule I, 5. It is a breach of order for the Speaker to refuse to put a question which is in order.-Jefferson, Manual, §3. A motion must be read to the House by the Speaker as often as any member desires it for information.-Jefferson, Manual, § 136 .

"sven this has sometimes been left to the discretion of the Chairman, as was the case in the Athenian Assembly. It is only necessary to recall the well-known instance when Socrates withstood the fury of the people and persisted in refusing to put the vote on the case of the ten generals who had been accused of not taking up the dead after the battle of Arginusæ.

${ }^{\circ 4}$ See above, $\$ 4 \mathrm{I}$. There is now one exception. The rules of 1887 lodged in the Speaker of the House of Commons discretionary power to put or refuse to put a motion for the closure of debate.-Bryce, North American Review, CLI, 388. 
ing day it would have been necessary for him to put the question on his own expulsion, if he had not stayed away, pleading illness. ${ }^{55}$

In the House of Representatives, whenever questions are under discussion in which the Speaker is personally interested, he usually calls some other member to the chair: when, for instance, the vote of thanks to the presiding officer is moved at the end of each Congress, the Speaker always leaves the chair, and often the chamber; in 1832, when a vote of censure was moved against Andrew Stevenson, ${ }^{56}$ he invited one of the members to take his place in the chair; ${ }^{57}$ in the Twenty-eighth Congress, 1843, the seat of Mr. Jones, of Virginia, who had been elected Speaker, was contested by Mr. John M. Botts; when the question of the controverted election came before the House, Mr. Beardsley of New York was called upon temporarily to perform the duties of the Speaker ${ }^{58}$ again in I 850 when Mr. Howell Cobb was charged with the mutilation of the Journal, Mr. Winthrop was called upon to take the chair; ${ }^{59} \mathrm{Mr}$. Blaine gave the chair to $\mathrm{Mr}$. Cox when an investigation of the Credit-Mobilier scandal was moved, ${ }^{60}$ and he was censured ${ }^{61}$ for keeping the chair during the report of the committee and the consideration of the

${ }^{B B}$ Macaulay, History of England, IV, 440-I.

${ }^{B 6}$ See above, $\S 73$.

"Debates of Congress, 22 Cong. I Sess., 2580.

${ }^{*}$ Cong. Globe, 28 Cong. I Sess., 13, 18, 21.

"House Journal, 31 Cong. I Sess., 17 I 3.

${ }^{\circ}$ House Journal, 42 Cong. 3 Sess., 8.

${ }^{11}$ New York World, March 5, 1873. 
report. ${ }^{62}$ Mr. Randall gave the chair to Mr. Carlisle during the investigation of a charge made against him in $1879 .{ }^{63}$

This slight divergence from English parliamentary procedure is significant. The Speaker of the House of Commons is such an absolutely impartial officer that there seems nothing unsuitable in his conducting business which concerns himself. The fact that such action would be felt a distinct impropriety in the House of Representatives shows the different position which its presiding officer occupies.

The Speaker of the House of Representatives has, under the rules and practice of the House,

8x. Some freedom in stating the question from debate. never been allowed of his own discretion to change or abridge a proposition $:^{64}$ he is under obligation to propose all motions and resolutions in the words of the mover ${ }^{65} \mathrm{He}$ is, however, on some occasions allowed a certain freedom in putting the question:

${ }^{62}$ House Journal, 42 Cong. 3 Sess., 427, 490, 494, 495, 496, 497, $498,500,501,502,504,507-509$.

${ }^{62}$ See above, $\$ 65$.

- Such is also now the practice of the House of Commons. But formerly the Speaker was allowed whenever he thought fit to frame a motion out of debate.-May, Parliamentary Law, 258-9. See Parliamentary History, XXXI, 197. In 1620 the Speaker was accused of "intricating or deferring the question, and hath made many plausible motions abortive."-Hatsell, Precedents, II, 239.

${ }^{6}$ If, however, a motion appears to the Speaker as incorrect in point of form, or contrary to some standing order, he states his reasons to the House for not putting it in the words given. And the House may adopt the alteration by motion of amendment without going through the form of taking a question.-Smith, Digest of the Kules of the House, 445. 
the House often gets into such a tangle over some subject that many members do not know what is pending; the Speaker is then asked to state the question; it is his duty to draw from the confusion of debate the point at issue and state it clearly to the assembly. In doing so, however, he has an opportunity to put his own construction upon it, and the shape which the question takes before the House is often apt to be largely influenced by the party predilections of the Speaker. Again, when the House resumes the consideration of a report from a committee, the Chair states at the same time the present condition of the subject.

Another duty of the Speaker is to announce the result upon every vote taken by the House, ${ }^{66}$ and through this apparently most simple 82. Announces function he is often able to give mate-
the vote. rial help to his party: when the House divides, the Speaker appoints four members to count and report the numbers; when the count is finished he may either announce the result promptly, or he may linger, and give his party every opportunity of beating up a majority; that majority once obtained he may announce the vote on the instant, and thus deny his opponents a like opportunity.

These are the ordinary duties of a presiding offi83. Appoints cer. So far as the Speaker is enabled

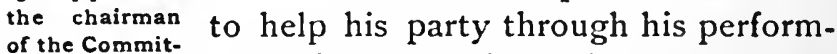
tee of the ance of these duties it is because perWhole.

mitted by the practice of the House rather than by set rules. But the Speaker, besides * Appendix D, Rule I, 5. 
unusual privileges in the performance of ordinary parliamentary functions, is given certain parliamentary powers usually denied in European practice to the Chair, and likely to be tinged by political considerations. One of these is that of appointing a chairman of the Committee of the Whole. ${ }^{67}$ In the House of Commons the chairman of this committee is either chosen by the House, or else the chairman of Ways and Means presides; ${ }^{68}$ the latter arrangement has now become the general practice. ${ }^{69}$ The rules of the House of Representatives were originally silent as to the mode of electing a chairman of the Committee of the Whole. For a short time he was appointed by nomination and vote. ${ }^{70}$ This practice proved inconvenient, however, and in the Third Congress his appointment was vested in the Speaker. ${ }^{\text {11 }}$

The Speaker upon motion puts the question that the House resolve itself into Committee of the 84. Speaker re- Whole. If agreed to, he appoints a quired to re- chairman and leaves the chair. The sume the chair when neces- metamorphosis of the House into Comsary. mittee of the Whole, however, does not absolve him from the duty of attendance. He must be at hand to resume the chair whenever a quorum of the committee is found not to be present, ${ }^{72}$ or

${ }^{\circ r}$ Appendix D, Rule XXIII, I ; adopted Nov. 13, 1794.

${ }^{86}$ May, Parliamentary Law, 360.

${ }^{80}$ Bradlaugh, House of Commons, 105.

${ }^{70} \mathrm{See}$ Annals of Congress.

"In I8II it was proposed that this privilege be taken from the Speaker, but the question was determined in the negative.-Annals of Congress, 12 Cong. I Sess., 569.

${ }^{72}$ Appendix D, Rule XXIII, 2. In such case, as soon as the 
whenever the committee sces fit to rise and report, or if any public business arises in which the House is concerned, ${ }^{73}$ or in case of sudden disorder. ${ }^{74}$ Since the committee as such has no power to suppress disorder, the last provision is very important : ${ }^{75}$ indeed, the chairman of the committee formerly did not occupy the Speaker's chair, but that of the Clerk, expressly in order that the Speaker might upon occasion return to his place without delay. Such is also the case in the House of Commons. We have a notable instance of the Speaker of that House resuming the chair to suppress disorder: the tellers on a division differed as to numbers; a disturbance arose with serious danger of bloodshed; the Speaker took the chair and the mace was forcibly laid on the table; disorder ceased and the members retired to their places. The Speaker stated that "he had taken the chair without an chairman makes his report, the Speaker proceeds to count the house. If a quorum should appear to be present, the House may and usually does resolve itself at once into the committee and proceed with the business. If a quorum should not be present, the Speaker adjourns the House.

${ }^{73}$ Jefferson, Manual, $\S \mathrm{I2}$. The Speaker takes the chair to receive messages from the President or Senate, or to receive reports from the committee on Enrolled Bills. No formal motion that the committee rise is necessary. The business announced, the chairman resumes the chair, and the House is again in committee.-Smith, Digest, 333.

${ }^{74}$ Jefferson, Manual, $\S \mathbf{I 2}$. This does not imply the necessity of his presence in the hall itself. As a matter of fact he often takes that opportunity to transact other business. But he must be within easy reach of the House.-See Hatsell, Precedents, II, 244.

${ }^{75}$ See Cong. Globe, 26 Cong. I Sess., 343; House Journal, 46 Cong. 3 Sess., II4. 
order to bring the House into order." There was some exception made against his action, but it was generally approved as the only expedient to suppress the disturbance. ${ }^{76}$

The Speakers of the House of Representatives have considered this instance sufficient precedent for acting in like manner in similar cases; but they have always felt considerable hesitation in taking such an important step unauthorized by the standing rules or an order of the House. The latest instance of the Speaker being obliged to resume the chair on account of disorder in committee was in 1880: the House was in Committee of the Whole on the refunding of the national debt; the offending members were Mr. Sparks and Mr. Weaver; after they had fiercely denounced each other, and had come nearly to blows, Mr. Speaker Randall took the chair for the purpose of restoring order, saying that he believed himself justified by parliamentary propriety and practice; the Sergeant-at-Arms, by direction of Mr. Randall, moved about the floor of the House with his mace of office, and order was restored; Mr. Randall then yielded the chair to the chairman of the committee, and business proceeded. "7 The Speaker must also be ready to take the chair in case the committee should wish to refer a point of order to him..$^{78}$ But unless a

${ }^{76}$ May, Parliamentary Law, 367-8.

$"$ Cong. Record, 46 Cong. 2 Sess., 31 I. See also 24 Cong. I Sess., 1209-10, for a member censured by House for disorderly conduct in Committee of the Whole.

${ }^{28}$ See May, Parliamentary Law, 366-7, for examples. 
point of order is reported by the chairman under instruction from the committee, the Speaker cannot rule in regard to what has occurred in the Committee of the Whole. When the committee rises the Speaker takes the chair, receives the report, and presents it to the House.

The case of the House in Committee of the Whole is not the only instance in which the 85. Appoints Speaker has the right of appointing the speaker its presiding officer: he appoints a pro tem.

Speaker pro tem. for a period not exceeding ten days. ${ }^{79}$ This is another privilege which is denied the Speaker of the House of Commons : ${ }^{80}$ in the English legislature a deputy Speaker appointed by the Commons performs the duties of the Chair when the regular official is unable to attend. ${ }^{81}$ It would seem better that the House

${ }^{70}$ See above, $\$ 32$.

${ }^{80}$ The Speaker of the House of Commons cannot leave his chair unless serious cause makes it necessary. John Quincy Adams quotes the Rolliad thus :

"There Cornwallis sits, and, oh, unhappy fate ;

Must sit forever through the long debate ;

Like sad Prometheus fastened to his rock,

In vain he looks for pity to the clock."-Memoirs, IX, 134 .

11 The chairman of the committee of Ways and Means is ex-officio deputy Speaker.-Bradlaugh, House of Commons, 105-6. Until 1853, however, there was no provision for supplying the Speaker's place. The House was obliged to adjourn. If illness prevented his attendance for any length of time, the House elected a Speaker with the usual formalities of the permission of the Crown and the royal approval. On the recovery of the Speaker the Speaker pro tem. would resign, and the Speaker be reëlected with a repetition of the same ceremonies.-May, Parliamentary Law, 219-220. In Canada there is no deputy Speaker, but the Speaker may not appoint a 
should appoint the temporary presiding officer; several times trouble has come out of decisions made by Speakers pro tem., for a temporary Speaker necessarily possesses diminished authority, and a chairman not chosen by the House is not directly responsible to the House. John Quincy Adams said, after some disturbance while a substitute was in the chair, that their confidence in the Speaker was a personal thing, and not transferable at pleasure to every man he might choose to put in his place. ${ }^{82}$ In I8I I a motion was made to take away from the Chair the right of appointing temporary Speakers. ${ }^{83}$ Nevertheless his powers in this particular have rather increased than diminished.

The powers of a mere substitute (for an hour or a day) are limited to keeping order, putting ques-

86. Powers and authority of temporary Speakers. tions, deciding points of order, and such duties. In rare instances the House confers some especial privilege upon him: thus, on one occasion, when the Speaker's seat was contested, it authorized him to name the Elections committee. ${ }^{84}$ But the Speaker protem. may authenticate papers by his signature ${ }^{85}$ and perform all other parliamentary duties of the Chair. Points of order decided by a temporary presiding officer may be referred to the Speaker when

substitute for more than one day.-Bourinot, Parliamentary Procedure, 164-5. There is the same rule in most of our State legislatures.-See Poore, Charters and Constitutions.

Cong. Debates, 23 Cong. I Sess., 3763.

"Annals of Cong., 12 Cong. I Sess., 569.

" Cong. Globe, 28 Cong. I Sess., 13, 18, 21.

${ }^{86}$ See House Journal, 48 Cong. I Sess., 1743. 
he resumes the chair. A temporary Speaker has less authority than the permanent officer, and his rulings are much more likely to be disputed. There has been at least one instance of disorder in the House due to the decisions of a feeble though well-meaning temporary Speaker: in $1832 \mathrm{Mr}$. Stanberry having used improper language in reference to the Speaker, a resolution of censure was moved upon his conduct; the Speaker called Mr. Clay, of Alabama, to take the chair; but Mr. Clay's decisions went against Mr. Stanberry; Mr. Stanberry thereupon grew very angry, declared Mr. Clay his enemy, insisted that he ought never to have been put in the chair, and demanded that he should leave it at once; Mr. Clay was anxious to comply with the demand, but the House would not allow it. The Speaker's appearance at that moment prevented further disturbance; he took the chair, and stated that he had left the House from motives of delicacy. And upon further objection being made to his conduct by Mr. Adams, he added with decision that the rules allowed the presiding officer to name any member to perform the duties of the chair for one day, that he had exercised this right less freely than his predecessors, but that he should do so whenever he deemed it proper. $^{86}$

Thus it is evident that the duty of appointing

87. Use made of the privilege of appointment. a temporary presiding officer is one which should be exercised with the greatest care. A strong man should be chosen, one who is respected by all

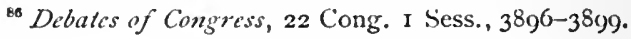


members, and who is likely to have authority with the House. He should also be a good parliamentarian, for the Speaker may be held responsible for the proceedings of the House during the administration of his substitute. ${ }^{87}$ It was formerly considered a necessary courtesy occasionally to appoint men of opposite political opinion: ${ }^{88}$ to do otherwise was to be considered a " narrow" and "partisan" official. Some Speakers, to be sure, extended the courtesy more freely than others; some did not offer it at all; or sometimes a Speaker would call only members of his own party to preside in the Committee of the Whole when there was general debate, and confine his courtesy solely to Private Bill day when general discussion was out of order, or to those times when a subject was on in which he was not interested. Even in times of political excitement eminent statesmen, whether friends or foes, were not ignored: Hunter, White, Stevenson, and even Polk called John Quincy Adams to the chair ${ }^{89}$ Winthrop was frequently invited to preside by political opponents. ${ }^{90}$ Now, however, Speakers always appoint not only men of their own party, but those whose views coincide most closely with their own: In the case of the committee of the Whole the subject which the committee is to consider is known before the chairman is appointed; the Speaker is always enabled, therefore, to put ${ }^{\circ 7}$ See Debates of Congress, 22 Cong. I Sess., 3867.

${ }^{80} \mathrm{~A}$ member called to take the chair asks to be excused if he wishes to speak on the matter that is to come before the House.

${ }^{87}$ Adams, Memoirs, IX, 370.

"House Journal, 3I Cong. I Sess., 808. 
that particular man in the chair who will handle the measure and guide the House as he wishes. On the other hand it is possible for the Speaker to silence some dreaded opponent by placing him in the chair: thus John Quincy Adams says that he was called to the chair December 13, 1836, when the President's message was under consideration, so that he might not enter into any of the debates on the resolutions. ${ }^{11}$

Another unusual parliamentary duty of the Speaker is that of referring bills and official communications

88. Refers bills, official communicationa and reports to committee or calendar.

to their appropriate committees, and reports from the committees to their appropriate calendars. ${ }^{92}$ The new rules of the Fiftieth Congress provided that the Speaker in referring such bills, communications, and reports should be freed from the necessity of laying them before the House. Previously this duty of reference, except as regards private bills, petitions, and river and harbor bills, had always been performed openly in the House. Members who disagreed with the Speaker were thus given an opportunity of moving that the matter should be referred in a way different from that which he had proposed, or, in case of a bill, that it be read in full in order that " intelligent action might be taken upon it." But this practice did not accomplish its aims: the titles were read by the Clerk, and the Speaker, amidst the great confusion arising from the lack of interest in this proceeding,

\footnotetext{
"Adams, Memoirs, IX, 322.

"Appendix D, Rule XXII, 3.
} 
and with no time for consideration, was obliged to refer them as best he could; misreferences were unavoidably frequent. The new system makes errors in commitment less common, and tends to save much time. But the new system also increases the power of the Speaker. In the majority of cases, to be sure, it is at once plain to which committee a bill belongs; still there are many about which it is more difficult to decide. The line of jurisdiction between certain committees cannot be so distinctly marked that difference of opinion shall never appear in regard to the commitment of bills. Thus in the Forty-seventh Congress a dispute arose in regard to the reference of a bill to increase the salary of the collector of the port of Indianapolis, and to define the application of a certain statute to the port of Indianapolis: the member who introduced the bill thought it ought to go to the committee on Expenditures in the Treasury; another said it should go to the committee on Ways and Means as it related to expenditures in the collection of revenue; but the Speaker thought it belonged to the committee on Commerce, and thither it was accordingly sent..$^{93}$

The importance of the decision lies in the fact that the fate of a bill may often depend upon the committee to which it is sent, that is, upon the Speaker's preference, for of the two committees about which the question has arisen, one may be inclined to act favorably and the other unfavorably. Of course the judgment of the Speaker may

"s Cong. Record, 47 Cong. I Sess., 279. 
be corrected by the House, but this is not so easily done as formerly. It had been held for a long time that a motion to correct an erroneous reference of a bill was privileged, and thus could be made at any time by any member; but under the present rules, if a bill is sent to the wrong committee the correction cannot be made except " by unanimous consent, or on the motion of a committee claiming jurisdiction, or on the report of the committee to which the bill has been erroneously referred." 94 The question is usually, moreover, purely one of a difference of opinion, with little more weight of argument on one side than on the other.

"Appendix D, Rule XXII, 3. 


\section{CHAPTER V.}

THE SPEAKER'S VOTE.

NE interesting function not yet considered is the Speaker's right to vote. It is usual for writers upon the parliamentary practice of the

89. The Speaker's vote not a casting-vote. House of Representatives to designate the Speaker's vote as "the castingvote." A brief examination of the subject, however, will serve to show that it is not only more than a casting-vote, but that it is something quite different. The literal meaning of the expression " casting-vote" is that vote which casts the preponderance on one side or the other, and decides the question accordingly. ${ }^{1}$ By this definition the casting-vote is necessary whenever the vote is tied, but not when the pending question is in such condition that one additional vote will produce a tie. The Speaker of the House of Com9o. E $\mathrm{ng} 1$ i $8 \mathrm{~h}$ precedent. 2 mons has never been allowed to vote unless the House is equally divided. ${ }^{3}$

${ }^{2}$ See Cushing, $\S 303$.

${ }^{2}$ It is the general practice in foreign assemblies for the presiding officer to vote only in cases of an equal division. Such is the custom in Hungary, Norway, Sweden, Switzerland. In Austria-Hungary the President of the Reichsrath never votes except in case of elections. -Dickinson, Rules and Procedure of Foreign Parliaments, 287, 289, 304, 306, 307. The Speaker of the Canadian House of Commons votes only on even divisions. Bourinot, Parliamentary Procedure, 391.

'May, Parliamentary Law, 343 ; for precedents see 343-7. 
One of the earliest writers upon parliamentary law thus states the rule: "Upon the division, if the numbers appear to be equal, then the Speaker is to declare his vote, whether he be a yea or no, which in this case is the casting-vote; but, in other cases, the Speaker gives no vote." It was very early demanded that the Speaker of the House of Commons should vote not only when the two sides were even, but also on those occasions when his vote, if given to the minority, would make the division equal. But the Commons have never consented to this claim: in 1601 when the division on a question was 105 yeas to 106 noes, the yeas claimed that they had the Speaker which would make it even; Sir Edward Hobbie said that when Her Majesty had given them leave to choose their Speaker, she had given them leave to choose one out of their own number, a citizen of London, and a member, and therefore he had a voice; to which Sir Walter Raleigh replied, being supported by the Speaker himself, that by taking the place which it had pleased them to impose upon him he was foreclosed of his voice, and was to be indifferent to both parties. The bill was accordingly lost. Cecil said, "The noes were 106 and the yeas were 105, the Speaker hath no voice, and though I am sorry to say it, lost it is and farewell it." 5 The claim has never been renewed in England. ${ }^{6}$

'Cushing, Parliamentary Law, 302. See Hatsell, Precedents, II, $24 x$.

${ }^{B}$ Hatsell, Precedents, II, 245.

-A practical objection to the Speaker of the House of Commons 
The rule of the House of Representatives in its original form ran thus: "In all cases of ballot by

91. Rules of the House of Representatives.

the House the Speaker shall vote ${ }^{7}$ in other cases he shall not vote, unless the House be equally divided, or unless his vote, if given to the minority, will make the division equal, and in case of such equal division, the question shall be lost." 8 It was the evident intention of this rule, not that the Speaker should have a mere casting-vote, but that he should be allowed to vote whenever his vote would make any difference in the result. The question, therefore, of the right of the Speaker to vote in contingencies not specifically included in the rules was bound to come up soon. It was raised December 4 , I803, on the amendment to the Constitution to change the form of voting for President and Vice-President. A vote of two-thirds was necessary; there appeared 83 in the affirmative and 42 in the negative; it wanted one vote in the affirmative to make the constitutional majority. The Speaker, Mr. Macon, claimed and obtained his right to vote, added his vote to the affirmative, and thereby the amendment to the Constitution was submitted. ${ }^{9}$ The right of the Speaker to vote in such voting on all occasions would be the necessity of his constantly going beyond the bar to vote, and thus leaving the chair empty.

7 There has been no instance for many years in which a vote by ballot has been taken in the House, but the rule is held to apply to all cases of elections. In this case the Speaker votes in the first instance like any other member.-Smith, Digest, 290.

- Annals of Cong., I Cong. I Sess., ro3.

- Annals of Cong., 8 Cong. I Sess., 775-6. 
cases has not since been questioned. In the Twentyseventh Congress the rule came up for consideration under another aspect: Mr. Speaker White decided that it did not oblige, but only gave him the right to vote in certain instances. ${ }^{10}$ This does not seem very sound, and it is questionable whether other Speakers or parliamentarians would have sustained his decision. Now, however, the rule covers the necessary ground by "requiring" the Speaker to vote when his vote would be decisive. ${ }^{11}$

By the practice of the House this rule obliges the Speaker to vote: [1] to break a tie, [2] to make a tie, [3] to complete a two-thirds vote, and [4] when his vote is necessary to make a quorum. ${ }^{12}$ It has been claimed, however, that the spirit of the rule does not include a negative vote on an even division, and when White in the Twenty-seventh Congress gave such a vote it was said to be unnecessary. ${ }^{13}$ But the Speaker should vote on an equal division, even although his vote may be cast in the negative: a question decided either affirmatively or negatively cannot be moved again during the same session; but it is not yet a completely settled point of parliamentary law whether on an equal division a question is so far decided as to come within this rule. If the Speaker votes in the negative, however, there

${ }^{10}$ Cong. Globe, 27 Cong. 2 Sess., 925.

"Appendix D, Rule I, 6 ; adopted Jan. 27, 1880. Cong. Record, 46 Cong. 2 Sess., 55 I-2.

12 Formerly it was not necessary for the Speaker to vote to make a quorum : his presence was sufficient.

${ }^{13}$ House Journal, 27 Cong. 2 Sess., 1382. 
can be no doubt that the question is decided negatively, and that the rule applies. This, therefore, is certainly a case where the Speaker's vote makes, or rather may make, a difference in the result, although not essential to decide the question then pending.

Thus the English and American legislatures act upon somewhat different principles in conferring a vote upon their presiding officers. 92. Basis of the The House of Commons gives its
Speaker's vote. The Speaker a casting-vote, purely for convenience, it would seem. Every care is taken to place the presiding officer of the Commons outside party strife: by taking the chair he and his constituents tacitly consent to lose his vote; he is provided with a casting-vote simply as an easy and at the same time a proper way out of the annoyance of even divisions. The Speaker of the House of Representatives, on the other hand, is not given a vote entirely for the sake of facilitating the business of the House: since he is a member of the House, elected like all his fellow-members by constituents, those constituents do not wish, for the sake of having their member in the chair, to give up their right to representation; if his vote, therefore, will make any difference in the result, he must be allowed to give it. It is not merely a duty which he must perform but a right that he possesses. ${ }^{14}$ Thus the Speaker of the House of Com-

14 The Vice-President, who is not a member of the Senate, does not vote except when the Senate is equally divided, that right being given him by the Constitution; but a President pro tem., being always chosen from the Senate, votes in all cases. 
mons gets his right to vote through his position as Speaker, the Speaker of the House of Representatives through his position as a member of the assembly.

Various Speakers, moreover, have asserted their right to vote on any pending question, and some have even exercised that right. This 93. Right to a claim rests upon the lack of prohibi-
member's vote. tion. The rules do not specifically forbid such action; they only enumerate the occasions on which he is "required" to vote; and the Constitution of the United States makes no distinction in conferring upon members of Congress the right to vote. Up to 1817 , however, the rules had always been interpreted to exclude any vote of the Speaker which did not settle an issue. The first Speaker to claim the right to vote as an ordinary member was Henry Clay, when the attempt was made in 1817 to pass the Internal Improvement bill over the President's veto. ${ }^{15}$ In 1824 a bill to grant General Lafayette $\$ 100,000$ was before the House. It was passed by a large majority. Before announcing the vote, however, Clay asked permission to record his own vote upon the bill. His request was unanimously granted. ${ }^{16}$

In 1833 it was proposed that the rules be amended to allow the Speaker a vote in all cases, the question to be lost if the House should be evenly divided; the amendment was defeated, but the record shows a large vote in its favor. ${ }^{17}$ Four years

${ }^{15}$ Annals of Cong., 14 Cong. 2 Sess., 1062.

${ }^{26}$ House Journal, 18 Cong. 2 Sess., $7 \mathrm{I}-74$.

${ }^{17}$ House Journal, 23 Cong. I Sess., 30, 77, 78. Vote 122-96. 
later a similar amendment was introduced; it was again lost, but again it was evident that many members approved the adoption of such a rule. ${ }^{18}$ Mr. Winthrop, however, in 1847 , stated his opinion from the chair that it was " not within the intention of the rule " that the Speaker should vote unless he could " affect the decision of the House." 19 Nevertheless Mr. Speaker Boyd during his administration twice asserted his right to vote when there was a division. On a motion to adjourn to a day certain he had his vote recorded in the negative. ${ }^{20}$ Again he claimed his right as a member and asserted his strong party attitude by casting an unnecessary vote in the well-known Burns case. It was moved that the rules be suspended in order to investigate the murder of a deputy-marshal while engaged in enforcing the law against " a violent and treasonable" mob in Boston; the object of the resolution was to make "proper and liberal relief" for his wife and child. As two-thirds were necessary to suspend the rules, and the vote stood 68 to 50 , the motion was in any case lost, but Mr. Boyd directed that his name should be recorded in the negative. ${ }^{21}$ In the Thirty-fourth Congress $\mathrm{Mr}$. Banks voted in favor of taking up a bill for the improvement of the harbor of Mobile, although the majority was recorded against it.. ${ }^{22}$ In $1877 \mathrm{Mr}$.

\footnotetext{
${ }^{16}$ House Journal, 25 Cong. I Sess., 63-64.

${ }^{10}$ House Journal, 30 Cong. 2 Sess., $211-212$.

${ }^{20}$ House Journal, 32 Cong. I Sess., 541-542.

"House Journal, 33 Cong. I Sess., 946-8.

${ }^{23}$ House Journal, 34 Cong. I Śsss., 499.
} 
Speaker Randall voted on the Electoral Commission bill, saying, "The occupant of the chair proposes to exercise his right to vote secured to him by the Constitution in his capacity as a Representative from the State of Pennsylvania. The Clerk will call my name." 23

It is interesting to notice that the claim to vote with the majority to make a two-thirds vote rests on the ground that the Speaker, as a member of the House, has a constitutional right to vote on any question before the House. ${ }^{24}$ The number of instances of the wider claim to cast a vote that could make no difference in the result has been, to be sure, very small; but it is a significant fact that in not one of those instances was there any objection made, or any manifestation that it was considered other than proper and legitimate action. It is one more illustration of the acceptance by the House of the double position of its Speaker as chairman and as member.

The arguments used in the debate of 1833 have a further significance than as relating merely to the Speaker's vote. The old rule, said 94. Practice of Mr. Patton, "is inconsistent with the
the States. spirit of our institutions. . . . It prevents the Speaker from exhibiting to the House, to his constituents, to his State, and to the whole Union, his undisguised opinions; . . moreover it deprives his district of the full benefit of

${ }^{23}$ Cong. Record, 4 Cong. 2 Sess., 105.

${ }^{24}$ Annals of Cong., 8 Cong. I Sess., 775-776. House Journal, 44 Cong. 2 Sess., 24. House Journal, 47 Cong. I Sess., 1674-1675. 
his representation of them, by taking away the moral influence which the opinions of such a man have upon measures of public policy; and in fine, to every practical purpose, except the mere numerical force of his vote, takes away from his State one of its representatives. . . . It will give him no new power, but . . . hold him to the just responsibility which every member of this House and every public man ought to encounter. . . . If the Speaker be thus deprived, any other . . members may be deprived of their votes. . . The rule I propose exists in all the following States: Tennessee, Kentucky, Ohio, Pennsylvania, New York, New Jersey, South Carolina, Maine, Maryland, Virginia, and I know not how many more. I have heard of no State in which a different rule than the one I propose exists, except Georgia. This rule is variously modified, to be sure, in those States named; for instance, in Kentucky and Tennessee the Speaker is required to vote first; in Virginia, and perhaps Pennsylvania, he votes last; in the former the idea seems to be that the vote of the House may influence his vote unduly; in the latter, the apprehension seems to be that he may perhaps influence the House improperly by his vote. These apprehensions I imagine to be alike fanciful and unfounded. I would have him vote when his name is called under the rule by which all the other members are called." 25

In general, as we have seen, Speakers do not vote on ordinary questions, although they claim their ${ }^{20}$ Cong. Debates, 23 Cong. I Sess., 2162-5. 
right on the few occasions when they desire to do so. It is probable that the Speakers themselves are 95. speakers usually very well satisfied with the content with practice in this respect. Not obliged to present sys- vote on every question, they are freed
tem.

from the necessity of openly showing themselves engaged in party warfare; they need not be always before the House as party men with party interests, and thus constantly in a position of antagonism to the minority. In this way they are enabled to retain the dignity which a presiding officer should possess. To be obliged to vote, moreover, and yet to be deprived of the privilege, possessed by every other member, of explaining that vote on the floor of the House, would often be a distinct annoyance. Yet in questions of great moment, or where they wish to go before the country, they cast a vote the more noticeable for its rarity.

When it is necessary for the Speaker to give a casting-vote he first states the vote on either side, 96. Reasons de- and then records his own voice with termining the the ayes or noes, as the case may Speaker'svote. be, and declares the question carried or lost, as the case may be. It has been considered the principle of general parliamentary law that a Speaker should so give his vote as to interfere as little as possible with the judgment of the House, and therefore that he should always vote, when practicable, in such a manner as not to make the decision of the House final. This is the practice in the House of Commons as exemplified 
by a vote on the Church Rates Abolition bill in 1861. ${ }^{26}$ In the House of Representatives, where the Speaker makes use of all the power allowed him either expressly or by inference, no such delicate idea of the honor of the presiding officer prevails; there is there no thought of the Speaker's effacing himself in a desire not to influence the House. ${ }^{27}$ Even in those cases where the question is merely one of consideration, and where the Speaker might therefore feel that until the matter had come before the House he should not take upon himself its rejection, he nevertheless votes against its consideration if it has not his favor. When, for instance, the bill organizing the Territory of Arkansas had passed the

${ }^{26}$ The Speaker said, "If the equality of voices had arisen in an earlier stage of the Bill I should have had no difficulty in the course I should pursue, because, guided by the rule which has been established by many able men who have preceded me in this chair, I should have desired so to vote as to give the House another opportunity of deciding the question for itself, rather than to have taken that decision into my own hands. But that rule does not prevail on the third reading of a Bill. We have now reached the third reading of this Bill, and I find that the House hesitates, and is unable to express a decision, whether this law shall stand or shall be changed. As far as I can collect the opinion of this House from the course of the debate, it seems to me the general opinion of the House is in favor of some settlement of this question different from that which is contained in this Bill, and I think I shall best discharge my duty by leaving to the future and deliberate judgment of the House to decide what change should be made in the law, if it should be their pleasure to make a change, rather than to take the responsibility of the change on any single vote. I, therefore, give my voice with the "Noes." - $163, E$. Hansard, 1322. The bill was put off for three months.

${ }^{37}$ See above, $\S 48$, for example of a Speaker giving his casting-vote directly to increase his power. 
House in 1819 and a motion was made to reconsider the vote by which an anti-slavery amendment had been lost, Clay voted against the reconsideration. Henry Clay always used his vote as if it were a member's and not a Speaker's vote; and the principle he followed seems to be the one now accepted.

The danger that the Speaker's example may carry somewhat greater weight than that of an ordinary member is guarded against 97. Speaker's
vote given last. by the custom which obliges a Speaker to give his vote last. Still, Clay demanded that his name should be called first when the Internal Improvement bill of 1817 was before the House, ${ }^{2 \pi a}$ and there have, probably, been other instances. The subject was discussed in the Twentyfifth Congress: some thought the Speaker should be called in the regular order, some that he should be called last; all agreed apparently that there was no sound reason for the Speaker's casting his vote before all other members; the matter, however, did not come to an amendment of the rules. ${ }^{23}$

27. See above, §93.

${ }^{28}$ In the Swedish Riksdag a singular expedient is resorted to in order presumably that the President shall not be influenced by the knowledge that his vote is to have the weight of a casting-vote. The voting there is effected by means of printed and unmarked, single, closed, and rolled-up slips of paper. The President before the counting, takes one of the slips, seals it, and puts it aside. If the count proves the remaining slips on either side to be equal in number, the sealed slip is opened and decides the question. But if a majority is already obtained the unopened slip must be at once destroyed.Dickinson, Rules and Procedure of Foreign Parliaments, 304. 
As at the time when the Speaker gives his vote it is no longer possible for him to influence 98. $P$ u b $1 \mathrm{i}$ c the House by argument or example, statement of to state his reasons is no infringement reasons. of the rule which prohibits him from participating from the chair in any proceedings of the House. In the House of Commons the Speaker explains his reasons in order to avoid the slightest imputation of partiality. ${ }^{29}$ But in the House of Representatives, where the Speaker usually gives a party vote, an explanation is not necessary. Such a Speaker as Mr. Winthrop, however, who did not look upon his office as entirely a political one, and who was a strict parliamentarian, is more likely to give an unpartisan vote in the chair, and to state his reasons for his vote. ${ }^{30}$

The question has several times arisen whether in case of an error in recording the votes the Speaker 99. Question of a vote after the intervention of other business. may change his vote after the intervention of other business: December 4, 1876 , a motion to suspend the rules was lost, lacking three votes of the necessary two-thirds; that day two members claimed that they had voted, but that their votes had not been taken down; the Speaker, Mr. Randall, allowed these votes, and then claimed and exercised his constitutional right to vote on any question before the House, and the resolution was held to be passed. ${ }^{31}$ In $1882 \mathrm{Mr}$. Randall headed a

${ }^{29}$ May, Parliamentary Law, 343. For precedents see 343-7.

${ }^{30}$ See House Journal, 30 Cong. 2 Sess., 2 I I-212.

"House Journal, 44 Cong. 2 Sess., 23, 24. 
strenuous opposition to exactly the same action by Mr. Speaker Keifer. $\mathrm{He}$ and his party friends insisted that after the mistake was announced they should be allowed to make the objection that no quorum voted, but that other business having intervened, no one, not even the Speaker, could vote. The whole matter after some debate was laid on the table. ${ }^{22}$ The theory then accepted has not since been disputed. The convenience and justice of the principle thus established is apparent: if a demand be made to put a subject, disturbed by an error in the record, back in statu quo, the previous status must include all points connected with the subject.

"House Journal, 47 Cong. I Sess., 1674, 1677. 


\section{CHAPTER VI.}

MAINTENANCE OF ORDER.

$\triangle$ PPOINTED in the first instance chiefly for the A preservation of order, the Speaker has ever found this one of his most important soo. Order on duties. To aid him in the task he is
the floor. invested, in case of any disturbance or irregular conduct, with authority to suspend all business until order is restored. ${ }^{1}$ If repeated calls and the suspension of business do not produce the desired result, he may call by name any member or members obstinately persisting in irregularity, a process equivalent to a complaint against such members, ${ }^{2}$ who thus make themselves liable to the censure of the House. ${ }^{3}$ As an example of the very frequent use of such powers may be cited a disturbance in the Thirty-first Congress when the Speaker, Mr. Banks, directed the roll-call to be suspended until quiet was restored. During the same session the excitement became so great on the proposed in-

'Cong. Globe, 30 Cong. I Sess., roor. Cong. Globe, 31 Cong. I Sess., 1748, 1776, 1923. It is sometimes necessary to direct the Sergeant-at-Arms to walk about with the mace, the symbol of authority.-House Journal, 48 Cong. 2 Sess., 498-500.

'Jefferson, Manual, \&XVII. Cong. Globe, 31 Cong. I Sess., 1776, 1923. See Hatsell, Precedents, II, 23r, 237-8.

Hatsell, Precedents, II, 238. 
troduction of a resolution to adjourn the House, that the Speaker was obliged to interpose and request gentlemen to suspend their conversation. After a pause business proceeded; but the House quickly returning to its former state of agitation, the Chair stated that if he could secure their obedience in no other way, he should be obliged to request the gentlemen by name to take their seats and suspend conversation. Business then progressed more smoothly.

In the Forty-fourth Congress the tumult reached so great a height during the reading of the Mulligan letters that the Speaker protem. had to threaten to call in the police of the Capitol. ${ }^{4}$ The House of Representatives has become so large, and consequently so difficult to govern and restrain, that instances of the use of the utmost authority allowed the Speaker under the rules are numerous. He has general control of the hall, the corridors and passages, and the unappropriated rooms assigned to the use of the House, ${ }^{5}$ and is authorized, in case of disturbance or unruly conduct in the lobby or galleries, to cause them to be cleared. ${ }^{6}$ He keeps

- Cong. Record, 44 Cong. I Sess., 361 (I876).

- Appendix D, Rule I, 3.

-Appendix D, Rule I, 2; adopted March 14, 1794. On one occasion in I8or the Speaker seems to have expelled a person from the gallery whose behavior was not disorderly, or at least not acknowledged as such by the House. A resolution was introduced that the power of the Speaker should not be construed to extend, except for disorderly behavior, to the expulsion of any person from the gallery, when the same is generally opened. But the resolution was lost by a narrow majority.-House Journal, 6 Cong. 2 Sess., 810-813. 
order in the House by very frequent use of his gavel which rests near the block of marble placed on the table before him. The President of the French Chamber of Deputies reminds a turbulent House of its duty by ringing a bell; if the tumult becomes very great he puts on his hat, which act adjourns the House for the time being. In the House of Commons, which is generally a quieter body, although violent scenes sometimes occur, no such device is necessary. A word from the Speaker usually quells any confusion that may arise.

Besides the general duty of preserving peace and decorum in the House, the Speaker has to restrain the members within the rules of order

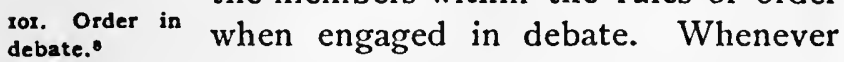
in his judgment a breach of order has occurred, or is about to occur, it is his duty to interfere at once. If a member is thus called to order during debate for having introduced irrelevant topics, used offensive language, or in any way transgressed the rules of the House, it is then the duty of the Speaker to explain to the member wherein he is at fault, to state the rule, and admonish him to proceed in order; or, if he thinks the occasion requires it, to call upon him to retract, explain, or apologize. If the member so admonished refuses to obey either of these directions, the Speaker may

'If a member's conduct is grossly disorderly, the Speaker may order him to withdraw from the House or may put the question that he be suspended from the service of the House.-Bradlaugh, House of Commons, 75.

'For authority of Speaker of House of Commons, see May, Parliamentary Law, 96, I04. 
name him to the House. If he still refuses to make any satisfaction, the Speaker can do nothing more. It then becomes the duty of the House to censure or to punish him. ${ }^{9}$ At all times any member may call a fellow-member to order, if the Speaker does not perceive the breach committed, or does not deem it a sufficient deviation from the rules to warrant interference, or through partiality to the member transgressing does not interpose. ${ }^{10}$ The following incident given by Giddings in his Diary shows how difficult it sometimes becomes to preserve order. "The Yeas and Nays were ordered on a vote about to be taken and when his [Adams'] name was called, he arose and commenced an argument. This was entirely out of order, and members from different parts of the House began to call him to order, as did the Speaker also. The cries of 'Order' became louder and more boisterous. The Speaker called louder and louder for 'Order! ORDER! ORDER!' but $\mathrm{Mr}$. Adams continued speaking, as though a perfect silence existed around him. The uproar increased, and the Speaker, rising from his chair, in

\section{- Appendix D, Rule XIV, 4 .}

* It has been claimed that it is no more incumbent upon the Speaker than upon any other member to call to order. (See Cong. Debates, 22 Cong. I Sess., 387 I-2.) But it was pointed out by John Quincy Adams that the rule of the House made this distinction-" The Speaker shall, or any member may call to order." If the case were otherwise the order and dignity of the House would be left to a mere accident. This is in accordance with Hatsell: "On the tenth of November, $\mathbf{1 6 4 0}$, it was declared that [if any one break the rules] any Member 'may' but Mr. Speaker 'ought' to interrupt him."-Hatsell, Precedents, II, 23 r. 
great agitation and excitement, with stentorian voice called on the House to assist him in enforcing the rules. Amid this tumult Mr. Adams suddenly dropped into his chair, and the uproar instantly ceased, before the Speaker had fully pronounced his desire for assistance." 11

It is the Speaker who always decides, subject to a revision of the House, all questions of order which 102. Speaker arise, or any which may be submitted decides ques- to him. ${ }^{12}$ He expresses his opinion on tions of order. the point raised, either immediately, or after hearing it discussed by other members. ${ }^{13}$ Since important points often come up as parliamentary questions, the Speaker can greatly help his party by the skilful handling of these debates. Over such a debate the Speaker has full control both as to recognition and time; the principle is illustrated by the following dialogue which took place between a member and Speaker Keifer in 1882 : "The Speaker. "The Chair desires to say that debate has run an hour longer than originally contemplated.'

“ Mr. Randall. 'Contemplated by whom.'

"The Speaker. 'Contemplated by the Chair. [Laughter.] The Chair will recognize gentlemen

"Julian, Giddings, 5x ; quoted from Giddings' Diary, December I3, 1838 .

${ }^{12}$ Appendix D, Rule I, 4 ; adopted April 7, I789.

13 Words objected to in debate must be reduced to writing in order that the Speaker may be better able to judge the matter.-Appendix D, Rule XIV, 5. In the House of Commons even the Speaker's words have been taken down in this way.-See May, Parliamentary Law, 3 Ig. 
with the understanding that if debate is not limited to short speeches, it will exercise its prerogative of putting an end to the discussion." " 14

When the Speaker makes his ruling he may state his reasons or not, as he may think proper. If the matter is of sufficient importance, however, it is well for him to give the grounds of his decision for the instruction of the House; ${ }^{15}$ and he may make such suggestions as he deems useful either to preserve the dignity or to promote the convenience of the House. It was urged on one occasion that it was not fair for the Speaker to give his reasons for a decision on a point which was not debatable, as the positions taken by the Chair could not be answered. But the Speaker replied that if he did not go beyond the point and did not enter into any arguments, it was not only his privilege, but his duty, to state the reasons for his decision. ${ }^{16}$

Since the Speaker usually decides parliamentary questions according to precedents, his rulings upon 103. Decision points which have been previously raised based on prece- do not always represent his individual dent.

judgment as he would pronounce it if the question were entirely new. Thus on one occasion the Speaker distinctly stated that his decision was opposed to his own views, but finding that such had been the previous rulings he felt bound

"Cong. Rec., 47 Cong. I Sess., 4318.

${ }^{16}$ See $\S 43$ for Clay's remark to Winthrop.

16 Cong. Globe, 23 Cong. I Sess., 512. A similar objection and a similar decision were made in the 3 Ist Congress. - House Journal, 31 Cong. I Sess., 832 . 
to conform to them. ${ }^{17}$ At another time the Speaker said that while he was willing to admit that the weight of the argument might be on the side of the gentleman making the point of order, the precedents were the other way, and he was not disposed to change the practice of the House. ${ }^{18}$ The Speaker is allowed to reverse his decision if upon reflection he thinks proper.

If the opinion of the Speaker is acquiesced in, it stands as the judgment of the House and is to be

104. A p pea $1 \mathrm{~s}$ from the deci- ber may appeal from his decision, ${ }^{19}$ prosion of the vided only that no business has inter-
Chair.

vened. In the House of Commons an appeal from the decision of the presiding officer on a point of order rarely occurs. In the House of Representatives such appeals are very common, but the decision of the Chair is usually sustained $;{ }^{20}$ the form of the motion is, "Shall the decision of the Chair stand as the judgment of the House?" ${ }^{21}$ A motion to lay on the table is equivalent to confirming the ruling of the Chair. In this instance as in all others the

${ }^{17}$ Cong. Globe, 26 Cong. $x$ Sess., 246.

${ }^{18}$ House Journal, 32 Cong. 2 Sess., 234. See also, for similar decision, House Journal, 3I Cong. I Sess., I 280.

${ }^{19}$ Appendix D, Rule I, 4. The rule as passed April 7, 1789, made an appeal by two members necessary on questions of order.

${ }^{20}$ The Speaker is generally a skilled parliamentarian; it would take a great deal, moreover, to make his party desert him. His decisions are now, therefore, almost never reversed.

${ }^{21}$ Originally the form of stating an appeal was "Is the decision of the Chair in order?" It was changed in 1807 to "Is the decision of the Chair correct ?" And about 1820 it was changed to the present form. 
Speaker retains his right to a casting-vote; if the numbers are equal he gives the vote which sustains his own decision. ${ }^{22}$ Parliamentary questions just decided on an appeal cannot be renewed. The decision as finally recorded furnishes the rule to be afterwards pursued. In certain cases no appeal is allowed from the Speaker's decision, as, for instance, pending the vote on a previous ruling of the Chair. ${ }^{23}$ If a question of order arises, moreover, during a division, or when the yeas and nays are being called, the Speaker himself decides peremptorily. ${ }^{24}$ It could not be otherwise, for a division upon a division would be very inconvenient and might give rise to further complications. When the division is over and the result declared, his decision may be revised by the House.

If the majority sustains the Speaker there is usually an end to the matter. On one occasion, however, John Randolph published an address to his constituents in complaint of a ruling by the

${ }^{22}$ The principle has been asserted in the House of Representatives that in the case of a tie vote on an appeal from a decision of the Chair, the decision is reversed since it is not sustained. (See Cong. Globe, 3I Cong. I Sess., I607-8.) But this principle has never been established.

${ }^{23}$ At ther times the Speaker, if he thinks proper, refuses appeals. See House Journal, 44 Cong. 2 Sess., 783-5. See also $\S 125$. It was decided in the 5 Ist Congress that an appeal from the decision of the Chair is not a dilatory motion.-House Journal, 5I Cong. I Sess., Ior 3 .

${ }^{24}$ For a remarkable instance of the Speaker of the House of Commons being called upon to use the summary authority with which a presiding officer is invested during a division, see Cushing, Parliamentary Law, $\$ 398$. 
Speaker. The Speaker, Howell Cobb, replied to the letter in the National Intelligencer, defining his position. But the participation of a Speaker in a controversy outside the House over his own rulings was very rare before the administration of $\mathrm{Mr}$. Reed.

It is of course important that the Speaker should be sufficiently versed in parliamentary law to make 105. Speaker all decisions himself; but he may, if he maydeclinede. please, decline the decision entirely cisions. ${ }^{25}$ and put the question in the first instance directly to the House, ${ }^{26}$ or request a member to appeal from his decision, in order that it may stand as the judgment of the House and thus carry greater weight as a precedent. ${ }^{27}$ Again it is sometimes more proper that the House should decide a question than the Speaker. In the early years of Congress when a question of order was made which concerned the Speaker, it was customary for the House by unanimous resolution to excuse the Speaker from making a decision. At present the Speaker usually submits all such questions directly to the House. ${ }^{23}$ In 1882 , for instance, a substitute was offered for the report from the

26 In the House of Commons the Speaker refers doubtful cases to the judgment of the House.-May, Parliamentary Law, 27.

${ }^{26}$ See House Journal, 6 Cong. 2 Sess., 810. Cong. Globe, 26 Cong. I Sess., 226. House Journal, 30 Cong. I Sess., 1249. House Journal, 32 Cong. I Sess., 6ri. House Journal, 47 Cong. 2 Sess., 684. House Journal, 48 Cong. 2 Sess., I27-9.

${ }^{27}$ See House Journal, 42 Cong. 3 Sess., 122.

${ }^{28}$ The Speaker of the House of Commons now decides questions of order that concern himself. 
committee on Rules, providing that the House should choose a board to select the committees. The point was raised that the substitute was not in order because not germane to the subject of the report; the Speaker, Mr. Keifer, stated that " while he had very distinct views as to the question of order presented, he would, in view of the peculiar relation of the proposed substitute to himself, submit the question to the House for its decision." 29

Again, in certain cases when the rules do not specify to whom the decision belongs, the Chair has denied its own jurisdiction. Thus it is 106. Questions left to the decision of the every question put unless he has direct House.

the duty of each member to vote on personal or pecuniary interest in it; and the Chair rules always that it rests with the member alone to decide as to the character of his interest in the pending question. ${ }^{30}$ Several other questions may arise which, although at first sight they might seem to fall within the province of the Speaker, clearly should not be left to his decision. If an amendment be proposed, for instance, inconsistent with one already accepted, it may be rejected by the House, but it is not within the competence of the Speaker to suppress it; " for," as Jefferson says in his Manual, " were he permitted to draw questions of consistence within the vortex of order, he

${ }^{20}$ House Journal, 47 Cong. I Sess., 320-33I.

${ }^{30}$ See ruling of Mr. Randall, House Journal, 44 Cong. 2 Sess., 2132. This ruling has been followed by the Chair in all cases which have since arisen. 
might usurp a negative on important modifications, and suppress instead of subserving the legislative will." ${ }^{31}$ When Clay was asked in I 8 I 3 whether it was admissible for a member of the House of Representatives to charge the government with violation of the Constitution, he said it was a matter for the decision of the House. ${ }^{22}$ Objection being made (1865) to the way in which a resolution rejected by both Senate and House was being pushed through, and the point raised that such action was neither fair nor proper, the Speaker replied that it was not within the province of the Chair to decide what is fair or unfair for the House to do. ${ }^{33}$ Again the Speaker leaves to the House the question of the privilege of a member. ${ }^{34}$ Whenever the point is made that any matter or proceeding is in violation of the honor, dignity, or privileges of the House, it is not a question for the Chair but for the House itself to determine. ${ }^{35}$.

The duty of restraining members within the rules of order when engaged in debate and of deciding ques-

307. Difficulty of deciding questions of order.

tions of order is the most difficult which the Speaker has to perform. It requires a thorough knowledge of parliamentary law and of the rules and practice of the House, with promptness, energy, firmness, courtesy,

${ }^{31}$ Jefferson, Manual, $\S 35$.

"Annals of Cong., I3 Cong. I Sess., 346.

"Cong. Globe, 39 Cong. I Sess., 61.

"Cong. Globe, 27 Cong. 2 Sess., 176.

${ }^{36}$ See decision of Mr. Carlisle, August 5, I886, House Journal, 49 Cong. I Sess., 2547-8. See also House Journal, 27 Cong. 2 Sess., 280. 
and great tact. While it is the duty of the Speaker to enforce the rules of the House in order to preserve its dignity, to facilitate business, and to secure the equal rights of all members and parties, he should not in the performance of this duty disturb the business of the House by interfering with every trifling deviation from the letter of the law, or show himself rigorous in matters of trifling importance. He should not weigh every chance expression, or understand equivocal expressions in an offensive sense. In calling upon a member to explain or apologize, the Speaker should use language likely to allay heat and restore harmony. In sustaining the call to order the Speaker may sometimes suggest the propriety of indulgence to the member, either on account of the particular circumstances of the case, or because indulgence has been usual in similar cases, or because the rule has not been strictly insisted upon. Again, innocent words are sometimes used in debate which are taken by an excitable member as personally offensive. The Speaker should then show by a few remarks that another interpretation may be put upon them, and that such was probably the meaning intended by the member; thus he may prevent further discord. It is also important that the Speaker should at all times pay the most careful attention to the proceedings of the House, so that he may interfere and check disorder in its beginning. Thus if he listens attentively to debate he may promptly interpose at the first word of personality or impropriety; but if such language is unchecked the member assailed claims the right to 
reply; disorderly language follows disorderly language, until at last confusion arises which might have been easily prevented by a prompt and watchful Speaker. Furthermore the Speaker is occasionally caused much trouble by members who object to a certain rule of the House. A rule once accepted, whatever its nature, the Speaker is unquestionably obliged to enforce it; yet it sometimes happens that the members who have opposed its adoption continue their opposition by appealing from every decision of the Chair made in accordance with the rule. Such was the course of action obstinately persisted in by certain members of the House, chief among them John Quincy Adams, after the passage of the gag law in 1837: the Speaker was kept busy deciding whether petitions relating to slavery should be read, and the House whether the decisions of the Chair should stand. ${ }^{36}$ Moreover, when the authority against a point is equally balanced, much tact and thought is still necessary in order to make the decision agreeable to the majority of the House, so that no time need be wasted on an appeal.

It is to this power of deciding complicated and perplexing questions that the Speaker owes much ro8. Speaker's of his influence over legislation. The in fluence rules may be enforced rigorously or mentary deci- leniently. If for instance a member is sions.

out of order the Speaker may delay calling him to order until the House demands it. The Speaker calls to order if a member does not ${ }^{36}$ See $\S 49$. 
keep to the subject, and it is he who decides, what does relate to the subject. If any part of a proposition is out of order it is within the Speaker's power to reject the entire proposition. ${ }^{37}$ Furthermore questions often arise capable of decision either way; then the Speaker may allow his personal bias to influence his decision. Often motions or arguments which may, if the Speaker favor them, be entertained without much stretching of the rules, can be easily out of order if they have not his good will. At the end of the Twenth-seventh Congress, when the point was made that it was time to adjourn, it being three minutes after two, the Speaker said, "The joint resolution requires the two Houses to adjourn at two o'clock to-day; but the Speaker is not the time-keeper of the House. If the House determines that it is not two o'clock it is the business of the House, and not of the Speaker." 38 Contrast this decision with the following made in the Fifty-third Congress:

"Mr. Bynum. I rise to a question of order. The time of this debate has already extended beyond the half hour.

"The Speaker. The gentleman from Mississippi has one minute of his time remaining.

"Mr. Bynum. According to the clock 33 minutes have already been exhausted.

"The Speaker. The Chair is the keeper of the time under the rules of the House.

"The gentleman from Mississippi will proceed."

"See House Journal, 47 Cong. I Sess., 1704.

${ }^{28}$ Cong. Globe, 27 Cong. 2 Sess., 925.

so Cong. Record, 53 Cong. 2 Sess., 4667. 
The "gentleman from Mississippi" was Mr. Catchings, a political friend of the Speaker, urging upon the House matters arranged by the Speaker and his associates in the committee on Rules.

After the previous question has been ordered it becomes incumbent upon the Speaker to see that debate does not touch the main question. Here there is considerable opportunity for favoritism on the one hand or overexactness on the other; and both charges have at times been brought against the Speaker. The adoption of the previous question was hailed in 1812 by some members as a necessary check upon the power which the Speaker had over debate, since, as was said in the discussion, "The chair might not always be filled with an intelligent, discriminating, and impartial man." 40

The.rules are elastic enough to give the Speaker more political power than their literal interpretation might imply; or the Speaker may nullify the rules by sticking close to the letter and not carrying them out in their spirit. Moreover, the rules are by no means complete: it would be impossible to frame a code which should distinctly cover every case that might arise in the House: much then is left to the Speaker's discretion. The question of the right of a Territorial delegate to object to the consideration of a proposition, when called up by a member, has been occasionally raised, and has been decided both in the affirmative and in the negative. Again it is so difficult to mark the exact line of distinction between public and private bills, that it

*Annals of Congress, 12 Cong. I Sess., 576. 
must often rest on the opinion of the Speaker. Under the decisions of $\mathrm{Mr}$. Carlisle, in the Fortyeighth and in the Forty-ninth Congress, all bills for the benefit of individuals and corporations, as for the construction of a bridge by a corporation or for a change in a name or location, or especially those affecting a national bank, were held to' be private bills. Prior to this they had been uniformly held to be public bills, and such is the present practice." Likewise, there can be no exact definition of " a question of order," and hence the important prerogative of defining these questions must be left to the Speaker; but since they are privileged they are subject to abuse; under the guise of a point of order a member often tries to get in an argument for or against the pending proposition; thus a lenient or a partisan Speaker may allow arguments under parliamentary inquiries which are clearly out of order. Questions of privilege are now defined by one of the rules of the House. ${ }^{42}$ Before the adoption of this rule, however, in the second session of the Forty-sixth Congress, each case presented had to be decided by the Speaker according to precedents, or the nature of the question. Even now the rule leaves much to the Speaker's judgment. Again the Speaker decides whether a question is capable of division, and whether amendments are germane to the subject under consideration.

Moreover, in some instances the rules appear ambiguous or their meaning seems obscure. The

"Smith, Digest, 473.

${ }^{4}$ Appendix D, Rule IX. 
interpretation of the rules belongs to the Speaker: he decides the meaning of terms, how much or how little they include. An interesting illustration of the Speaker's power through the interpretation of the rules occurred in the Twenty-sixth Congress: a bill supplemental to the act granting preëmption rights to settlers on the public lands had been returned from the Senate for the Speaker's signature; Speaker Hunter, however, refused to sign the bill on the ground that in the meantime the question of its reconsideration had been raised and was before the House ; ${ }^{43}$ there was nothing in the rules to prevent a decision that the House could not reconsider a bill gone to the Senate." Another of the many instances scattered through the records occurred in the Forty-eighth Congress: the point was made that it was not in order to refer a bill to a committee which did not have jurisdiction of the subject; Mr. Carlisle overruled the point on the ground that the House was competent to refer a bill to any committee it pleased..$^{45}$

The decisions of the Speaker are often very important. Presiding officers make parliamentary law as judges in the courts make common law. New cases often arise to which neither the rules nor practice of the House, nor any precise canon of parliamentary law are exactly applicable. ${ }^{46}$ It then be-

43 House Journal, 26 Cong. I Sess., ro33.

"For questions of order see appendices of House Journals. By a study of these one can easily see how the Speaker makes parliamentary law, and how large is his power over legislation thereby.

4t House Journal, 48 Cong. I Sess., 7034.

- Thus Speakers have decided, and their decisions have been main- 
comes the duty of the Speaker to settle such a point by a careful consideration of analagous cases, if any have occurred. The importance of his ruling lies in the fact that it becomes a precedent for future proceedings. A parliamentary decision, moreover, may have great political importance.

tained by the House, that inasmuch as the motion to lay on the table is not debatable, so by analogy the motion to reconsider must be put without debate.-Smith, Digest, 92. 


\section{CHAPTER VII.}

DEALING WITH OBSTRUCTION.

$\triangle$ NEW duty has been recently forced upon the A Speaker by the extent to which legislative 109. Abuse of obstruction has been carried in the power by the House of Representatives. Repreminority.

sentative institutions rest on the principle of government by majorities, but they should include also the protection of the minority in many reserved rights, and should provide guarantees against hasty law-making. One of the chief aims of the rules of the House is to give a careful consideration in all its aspects to every pending question, and by thus allowing time for party passion to cool to secure calm and deliberate legislation. Such is the special object of the requirement that bills shall be read three times before the vote is taken upon them. ${ }^{1}$ One of the difficulties of representative institutions, moreover, was early seen to be the possible control of the country by small majorities perhaps representing an actual minority of voters. Democracy demands that the voice of the people shall rule, but it is often difficult to be sure that that voice is expressed by a majority in the legislative assembly. The protection of the rights of the

${ }^{1}$ Appendix D, XXI, I ; adopted April 7, I789. 
minority makes it more likely that the voice of the people may be obtained on any specific question. Of late years the minority has carried the protection afforded it by the rules beyond all legitimate use to an attempt to thwart the legislation of a responsible majority. The methods of obstruction are many, but the two principal devices are: breaking a quorum by refusing to vote; and interposing dilatory motions, such as to adjourn, to fix a day to which the House shall adjourn, for tellers, and for the reading of bills. The only justifiable excuse for obstruction is that it may call the attention of the country to measures which the majority party in a moment of heat may be endeavoring to force upon the people. But while the power of the minority to delay business may thus be only a necessary and wholesome precaution against the temptations of the majority to hurry through party measures, beyond a certain point it defeats the main object of all legislative assemblies. The highest law of every parliamentary body, as has been well said, is that it shall have the right to do the business for which it was created. If the practice of obstruction goes so far as to threaten to impede the proceedings of the House, and the rules are not efficient to prevent it, it is the duty of the presiding officer to use every power bestowed upon him by the rules, by practice, or by reasonable analogy to put an immediate stop to it. This principle has not hitherto been fully recognized in the House of Representatives. Obstruction has been allowed to flourish, and the result is that through 
its constant use it has come to be considered a fair and just privilege of the minority.

The whole subject of obstruction in Congress becomes more interesting when it is considered that

rxo. Obstruc. tion in the House of Commons. the same difficulty has at the same time presented itself in another country. In both the House of Commons and the House of Representatives the legitimate power of the majority was restored to it by the interference of the Speaker, and by the assumption on his part of extraordinary power. In 1881, when the House of Commons had sat for forty-one hours, all business obstructed by the action of the members of the Home Rule party, Mr. Speaker Brand took matters into his own hands, refused to entertain any further motions, refused even the right of debate, and proceeded to put the main question on his own authority. He said: "The dignity, the credit, and the authority of this House are seriously threatened, and it is necessary that they should be vindicated. Under the operation of the accustomed rules and methods of procedure, the legislative powers of the House are paralyzed. A new and exceptional course is imperatively demanded, and I am satisfied that I shall best carry out the will of the House, and may rely on its support, if I decline to call upon any more members to speak, and proceed at once to put the question from the chair. I feel assured that the House will be prepared to exercise all its powers in giving effect to these proceedings. Future measures for censuring disorderly debate, I must leave to the judgment of the House; 
but I may add that it will be necessary either for the House itself to assume more effectual control over its debates, or to entrust greater authority to the Chair."

The House took the hint thus given. In 1882 an order was adopted allowing the Speaker, when in his judgment a subject has been adequately discussed, and when it is evident that the general opinion favors the putting of the question, so to inform the House. ${ }^{2}$ Before 1882 the only limitation on debate was an order made in 1604 " That if any man speak impertinently, or beside the question in hand, it stands with the orders of the House for the Speaker to interrupt him, and to have the pleasure of the House, whether they will further hear him." 3 It was also provided by the rules of 1882 that if the Speaker shall consider a motion for adjournment, either of debate or of the House, an abuse of the rules, he is to put the question thereupon to the House ${ }^{4}$ moreover he may now call on

'Bourinot, Parliamentary Procedure, 379. In the Lower House in Belgium the President of the Chamber and the Prime Minister consult as to the advisability of clôture.-Dickinson, Rules and Procedure of Foreign Parliaments, 222. The President of the Danish Chamber, if he considers the debate improperly prolonged, can propose the clôture, which is decided by the Chamber without debate.-Dickinson, 102, 224. The clôture may be moved by the President of the House in Spain.-Dickinson, 266.

'Hatsell, Precedents, II, 230. How much Speakers may have desired some power over debate may be seen from an account of a Speaker, who, tired of the long debate, was wont to shout out lustily: "I am tired, I am weary, I am heartily sick of this!"-May, 503, note.

'Bourinot, Parliamentary Procedure, 380-I. 
members who in his opinion frivolously or vexatiously claim a division, to rise and be counted in their places.

To these powers, Mr. Bryce tells us, it has seldom been necessary to resort, since their mere existence has operated to check dilatory motions and purely frivolous demands for divisions. And the Chair by refusing to conform always to the desires of the majority, " has shown that he did not intend to gag the minority in the interests of the majority - that he should protect the minority while helping the majority to perform its duties of legislation." Mr. Bryce tells us also that the Speaker at first, feeling that the right of continuing or closing a debate rested with the majority, allowed the vote to be taken on the question of closure, whenever there was no absolute impropriety. But perceiving that this was a right which the majority was apt to abuse, he has often lately, against the wishes of the leaders, refused to put the closure motion. ${ }^{5}$ What will be the ultimate result of conferring such power upon the Chair, is by no means sure: the Speaker has been given powers which can be used for the great advantage of a party; there is nothing but a sentiment, a tradition-and not a very old tradition at best-to prevent a majority from placing in the chair a man who will not hesitate to use his powers at the dictate of his masters. ${ }^{6}$

- See North American Review, 385-398.

- The Spectator speaks of the increased powers of the Speaker, especially of his control of the closure, and thinks that those powers will soon be further increased. - Spectator, LXVIII, 389-390. This 
One of the most common forms which obstruction has taken in recent years in the House of Represis. Refusal to vote. - Precedent of John Quincy Adams. sentatives is the refusal to vote to make a quorum. One of the earliest rules passed by the First Congress of the United States compelled members present to vote upon every question in which they had not a direct personal interest. ${ }^{7}$ This obligation was held to be imperative until in 1832 John Quincy Adams refused to vote when within the House. His action produced an excitement in Congress which is especially interesting in the light of later events. A resolution to censure Mr. Stanberry, of Ohio, for an improper reference to the Speaker was before the House. When the yeas and nays were ordered on its adoption, John Quincy Adams asked to be excused from voting and at the same time presented his reasons in writing. The House refused to excuse him, and the Clerk was ordered to call the roll. Mr. Adams declined to answer to his name, saying that he did not refuse to vote from any contumacy or disrespect to his fellow-members, but from conscientious motives. A motion was then made to reconsider the vote by which the House had declined to excuse Mr. Adams. In the debate upon this motion, the future consequences of allowing a violation of the old and important rule involved were clearly prophesied. Mr. Foster said that if any member of the is significant as showing a tendency on the part of large assemblies to meet the same difficulties in the same way.

' Appendix D, Rule VIII, I ; adopted April 7, r789. 
House might persist in refusing to vote upon the important questions that came before it, there would be an end to all legislation. When the House was not full, it would be necessary, in order to defeat its action, only for the minority to refuse to vote, and a question could not be decided for want of a quorum. The House refused to reconsider its vote. The Speaker then read the rule by which all members who are within the hall when the question is put, are required to vote, and stated that it is the duty of every member to vote upon one side or the other. By direction of the Chair the Clerk again called the name of $\mathrm{Mr}$. Adams, who made no response. Mr. Drayton rose to offer a resolution that Mr. Adams having committed a breach of the rules, a committee be appointed to report the course which should be adopted in a case at once so novel and so important. He said that the Constitution had authorized the House to establish rules for its government. Under these rules every member in the House was bound to vote. Besides the grave consideration of the violation of the rules this course might be attended with dangerous consequences. The next day, after some further debate, the whole matter was laid on the table. ${ }^{8}$

Since then the House has always been unsuccessful in its attempts to enforce the rule which requires members to vote. Mr. Adams frequently refused

- Debates of Cong., 22 Cong. I Sess., 3895-39II. See also decision of the House, March 10, 1839. House Journal, 26 Cong. I Sess., 575 . 
to vote in spite of the most determined efforts of the House to force him to do so. And while in this first instance his persistency was due to purely conscientious motives, we know that he would not have hesitated to use the same means for the purpose of preventing action on any measure. In his Diary of March 25, I840, we find this entry: "A quorum voting. Thirty-four Whigs afraid to abstain from voting upon a call of yeas and nays. If only five of them had had the firmness to abstain from voting, the majority would even have been compelled to adjourn for want of a quorum." g It was only a little later that the refusal to vote did come into use as a means of obstruction.

It has always been the practice in Congress not to regard a vote as final on which there is a count, Ir2. Refusal to unless the count shows that a quorum vote to make a has voted, and this practice has prequorum. - In- cented one of the most effective, and dilatory tac- at the same time one of the easiest tics.

means of blocking public business in Congress-the easiest, because men simply by sitting still could produce more effect on the legislation of the country than by any amount of effort. Obstruction was carried so far in the Forty-fifth Congress that Garfield said: "A minority of not one-third even have been able under the rule to say to this House, 'You may take up an appropriation bill and pass it, you may do such things as we shall select and point out to you; but you shall not even consider any bill that we, the minority, do not con-

-Adams, Memoirs, X, 242-3. 
sent to.' This demand is intolerable, is revolutionary and cannot be submitted to without dishonor." 10

Legislative obstruction has proved a welcome weapon to whichever party has been in the minority. Responsibility for its evil effects must be shared equally by all parties. Not checked in the first instance, filibustering was allowed to flourish; and as men gained practice in parliamentary tactics, the custom was more and more abused, ${ }^{11}$ until in I 889 one man was able to prevent the transaction of any business: Mr. Weaver appears to have kept the House engaged in roll-calls for eight days in his attempt to secure the consideration of the bill organizing the Territory of Oklahoma. ${ }^{12}$ One man dictated to three hundred the business of the House. According to Mr. Lodge, the Fiftieth Congress, which was in longer continuous session than any other Congress in our history, passed, outside of the measures which received unanimous consent, practically nothing except one great party measure, and that went through merely because the opposition allowed it to pass. ${ }^{13}$

With the advance of time filibustering has become

113. Attempts to stop filibus. tering before 1890.

not only more common, but a much more serious matter to the people. As territory extends and the population grows, as railroads and corporations,

${ }^{20}$ Cong. Record, 47 Cong. I Sess., 43ri.

${ }^{21}$ March 24, 1880 , the motion to adjourn, or to take a recess, or to adjourn to a day certain, was made eighteen times before 12:15.House Journal, 46 Cong. 2 Sess., 852-872.

${ }^{12}$ Cong. Record, 51 Cong. I Sess., 1215.

"North American Review, CXLIX, 293. 
commerce and manufactures increase, the business of the country is greatly multiplied, and legislation must keep pace. To legislate for seventy millions of people, even with the way made smooth, is no easy task; but the systematic filibustering which has hitherto been allowed causes the business of the country to accumulate on the House calendars to an alarming extent. While for some time the minority's abuse of its privileges has been appreciated, yet the method by which it might best be stopped could not be agreed upon: when in the Thirty-eighth Congress it was proposed that members not voting should be counted as making part of a quorum, Speaker Colfax decided that it was not a proper course. ${ }^{14}$

In the Forty-third Congress the opponents of the Force bill, which General Butler was trying to push ir. Duringthe through before the end of the session, Force bill de- attempted to defeat its passage by bate, 1875 .

refusing to vote when their names were called. After repeated calls of the House and efforts to get a quorum recorded as voting, the question was again raised whether, since every one knew that there was a sufficient number of members in the hall to make a quorum, the Speaker could not declare a quorum present. General Butler protested that it was possible. Others came to his support and urged this course. But Mr. Blaine, Speaker of that Congress, ruled that the Chair could not declare a quorum unless it was shown by a yea and nay vote, and pointed out that although the "Cong. Globe, 38 Cong. I Sess., 2893. 
Speaker should decide on the presence of a quorum until the roll-call is resorted to, " that is the last mode of certification from which there is no appeal." He predicted, moreover, that any deviation from this principle would be followed by the most alarming results. General Butler offered various resolutions by which a quorum might be obtained or declared; he even moved that Mr. Randall, one of the stubborn minority, be brought to the bar of the House to show cause for disobedience of the rules and contempt of authority. His strenuous efforts to oblige the minority to vote were, however, all ineffectual. ${ }^{15}$ The urgency of the case was not then felt strongly enough to break the longestablished custom, and the problem remained unsolved.

On January $28, \mathrm{I} 880$, when the subject again came up for consideration during the debate on a revision xx. Proposed of the rules, Mr. Randolph Tucker, of amendment of Virginia, an able constitutional lawyer, $\mathbf{x 8 8 .}$

moved the following amendment to the rules: "Whenever a quorum fails to vote on any question and objection is made for that cause, there shall be a call of the House, and the yeas and nays on the pending question shall at the same time be ordered. The Clerk shall call the roll, and each member as he answers to his name, or is brought before the House under the proceedings of the call of the House, shall vote on the pending question. If those voting on the question, and those who are present and decline to vote, shall together make a ${ }^{15}$ Cong. Record, 43 Cong. 2 Sess., I72I-5I. 
majority of the House, the Speaker shall declare that a quorum is constituted; and the pending. question shall be decided as the majority of those voting shall appear." 16 The debate on the amendment showed the Republicans decidedly hostile to it, and as there was also objection on his own side, Mr. Tucker the next day withdrew the amendment. ${ }^{17}$ But many men who in 1880 were opposed to such a decided innovation in the practice of the House of Representatives, after witnessing for ten more years the consequences of the old custom, began to realize that however reluctant they might be to curtail the power of the minority, it must be done if a majority were to justify its existence. It only remained for some one to appear who was willing to overturn the precedents of many years and to face the certain rage of a defeated minority. The task was undertaken by Mr. Reed, Speaker of the Fifty-first Congress.

In the Fifty-first Congress the Republicans had a small majority, and as all their members did not x16. Mr. Reed's appear during the first weeks of the action on ob- first session, it was impossible for them struction, 1890 . alone to furnish a quorum. Such a moment was a glorious opportunity for filibustering, and neither party could have resisted it. It was only chance that made the Republicans the tempters and the Democrats the tempted. But Mr. Reed took the chair December 2, 1889, with the determination that neither unnecessary delays

16 Cong. Record, 46 Cong. 2 Sess., 575.

${ }^{17}$ Cong. Record, ${ }^{6} 6$ Cong. 2 Sess., 604. 
in formal proceedings, individual claims, nor the obstruction of an organized minority should prevent a majority of the House from transacting business. January $2 \mathrm{I}, \mathrm{I} 890$, therefore, he began the battle by refusing Mr. Bland's demand for tellers on a motion to adjourn. ${ }^{18}$ His action at once raised a storm, not only in the House, but throughout the country. The arguments against it presupposed, however, that Mr. Bland's motion was made in good faith. If such had been the case Mr. Reed would certainly have had no basis for his decision: an inherent privilege of all legislative bodies is the right to test the accuracy of the Speaker's count by an independent count made by representatives of both sides. The members who doubt a vote do not impeach the Speaker's honesty: they merely question his opportunity to observe to the best advantage. Especially in a body as large as the House of Representatives, and where the confusion is often unavoidably great, it is evident that an accurate count by the presiding officer must be attended with some difficulty; an appeal from the Speaker's count should therefore be allowed. As a matter of fact, however, it was plain to all that Mr. Bland was simply carrying out the Democratic policy of obstruction, and that his motion to adjourn was purely dilatory. As such Mr. Reed refused to entertain it. January 30, I 890 , the contested election case of Jackson versus Smith was called up for the consideration of the House. ${ }^{19}$ The Constitution provides

${ }^{18}$ Cong. Record, 5 I Cong. I Sess., 699.

${ }^{20}$ Cong. Record, 5 I Cong. I Sess., 913. 
that " Each house shall be the judge of the elections, returns, and qualifications of its own members;" 20 to settle the disputed title of a member to his seat is, therefore, the highest constitutional function of the House. The yeas and nays were demanded on the question of consideration, and the vote stood: yeas 161 , nays 2 , not voting 165 . The members who had demanded the yeas and nays sat in their seats silent. After the announcement of the vote the objection of "no quorum voting" was at once raised, whereupon the Speaker directed the Clerk to record the names of those present and refusing to vote. One of the Democrats immediately appealed from the decision of the Chair. Amidst great confusion and repeated cries of " revolutionary " and " unconstitutional," Mr. Reed continued to call the names of those present and not voting. When he had finished he rose to state the vote, and made some remarks in justification of his rulings. The indignant protests of the minority were all in vain. The appeal from his decision was laid on the table by a majority of a quorum, and not a majority of the House. ${ }^{21}$

The next morning the Speaker again counted those not voting in order to make a quorum for the approval of the Journal, and refused to entertain any appeal from his decision, stating that the House had already decided on the question of a quorum. The greatest confusion reigned in the House. The shouts of the defeated minority made the regular

${ }^{20}$ Constitution, I, 5.

${ }^{21}$ Cong. Record, 51 Cong. I Sess., 914-925. 
procedure of business difficult: the Speaker was denounced as a tyrant, despot, czar: the roll-call was constantly interrupted by the noise and disturbance: ${ }^{22}$ never before had the House of Representatives witnessed such a scene-its presiding officer condemned, and subjected to the most violent abuse, on account of a parliamentary decision. But Mr. Reed by his calmness under personal accusations, and by the firmness with which he stood his ground against both importunity and attack, guided the House through its stormy crisis to the establishment of a more sound and salutary principle of parliamentary law. Whether Mr. Reed's primary object was a desire to improve parliamentary law in the United States or whether he had political and party ends to serve by the course which he pursued, it is not necessary to consider. If his decisions were made to meet the partisan exigency of the hour, the effect of his action is the same, and it is with the effect only that we are here concerned. The dilatory tactics of the minority were doomed to defeat. Mr. Reed announced his intention from that time to disregard all motions and appeals, however parliamentary in themselves, which were resorted to simply for the purpose of delay. ${ }^{23} \mathrm{He}$ carried out this principle, not in the arbitrary way that was predicted, but very leniently: he refused motions from Republicans as well as from Democrats; he entertained and allowed appeals on many dilatory motions; yet by disregarding many he

$$
\begin{aligned}
& { }^{22} \text { Cong. Record, } 5 \text { I Cong. I Sess., } 944 . \\
& { }^{23} \text { Cong. Record, } 5 \text { I Cong. I Sess., } 959 .
\end{aligned}
$$


greatly facilitated the business of the House. His two important parliamentary decisions were: first, that a vote is valid if a quorum be actually present, though the quorum may not vote; and secondly, that motions obviously and purely dilatory, designed only to block the doing of business, need not be entertained.

Let us look at Mr. Reed's ruling in regard to the quorum, and see what authority he had for it. As 117. Authority our system of parliamentary law is for quorum de- based upon the-English methods of cision.- Prac- procedure, we naturally turn first to ment and text the practice of the House of Commons. ${ }^{25}$ May tells us that the Speaker of the House of Commons enforces the rule that members when present must vote: ${ }^{26}$ if a quorum does not vote, the presence of a quorum is deemed sufficient to establish the validity of any action.

Cushing and Crocker, the ablest American writers on parliamentary law, have added their voices to the obligation of members to vote, ${ }^{27}$ and Crocker at least has defined the consequences of that obligation. He says: "It is the duty of every member

${ }^{24}$ See North American Review, CLIII, 737-748, for practice of Continental assemblies.

${ }^{25}$ Precedents from English parliamentary practice have been given a high place in the House of Representatives, and have been occasionally quoted by Speakers and accepted by the House as sufficient ground for action.

${ }^{36}$ May, Parliamentary Law, 334.

${ }^{27}$ "When a question is put, all those members and those only who are properly in the House are allowed and may be compelled to vote."-Cushing, Parliamentary Law, §1795. 
of an organization not only to be present at its meetings, but also to vote on the questions that may arise. Hence it is that a vote is binding and valid on an assembly if a quorum of the assembly is present, even if a quorum does not vote. Any other course would enable a small majority by neglecting their duty to have more power than they would have if they voted. Thus if fifty members constitute a quorum, and fifty members are present, it would be obviously wrong to allow one member who is opposed to a pending motion to prevent the passage of the motion by abstaining from voting, when if he voted the motion would be carried by a vote of forty-nine to one. In all cases, however, when in a counted vote it appears that a quorum has not voted, the presumption is thereby raised that a quorum is not present, and unless the presumption is overthrown, the vote must be considered void. This presumption can be overthrown by proof that a quorum was actually present at the time the vote was taken, and if it is so overthrown, then the vote is valid. If a quorum does not vote but is in fact present, the secretary should make entry in the records that on a count of the assembly it was found that a quorum was present." 28 The duty of attendance, which implies the duty of voting, is thus laid down by Cushing: "The right of a legislative assembly after it is regularly constituted to have the attendance of all its members (except those who are absent on leave, or in the service of the assembly) and to enforce it if necessary, is ${ }^{20}$ Crocker, Principles of Procedure, $\S \mathbf{I I 4}$. 
one of its most undoubted and important privileges." 20

The claim that a member cannot be counted to make a quorum unless participating in the business 188. Bearing of of the House, does not appear to be the Federal founded on the Constitution, which auConstitution.

thorizes a smaller number than a quorum to compel the attendance of absent members. ${ }^{30}$ It is evident that the purpose of the framers of the Constitution was to prevent delay in the execution of business: as they provided only for the attendance of members, that attendance must have been considered sufficient to attain their object: if anything more were needed, the Constitution would have provided it. The power thus given to the House to compel the physical presence of a member implies the power to take benefit in some way from that physical presence: the law is in effect violated by personal presence with a refusal to vote, if the personal presence is not to be reckoned to make a quorum.

Yet it was claimed that after the power given by the Constitution to bring in members has been exhausted, still they are not present unless they desire to be so considered. The essential point is that the Constitution does not say that a majority voting shall constitute a quorum, but that " a majority of the House shall constitute a quorum to do business." If it were true that there must be a major-

${ }^{20}$ Cushing, Parliamentary Law, $\S 264$. See also Cushing, \$1803, I8ro, 1812.

${ }^{30}$ Constitution, $\mathbf{1}, 5$. 
ity acting on a question to constitute a quorum, then whenever the minority refused to vote, a majority of the whole House would be necessary to pass a measure. Some of the State constitutions require such a majority. ${ }^{31}$ As it is not so provided in the Federal Constitution it is evident that no such meaning was intended..$^{32}$ It is simply required that a majority shall constitute a quorum, and then the decision of a question shall be by the majority of that quorum..$^{33}$ Especially should this be the construction put upon the passage when by breaking the silence men could, as a majority of a quorum can, defeat the act to which by their silence they have consented. A great deal has been said about the business of the House being done by a " minority of a quorum." The " minority of a quorum" has to be sure a disagreeable sound; it suggests something of usurpation or underhand methods. But it must be remembered that if a minority of a quorum passes any measures, it is only because the majority of the quorum allows it to do so. The responsibility for these measures, therefore, rests not with the Speaker or with the minority of the quorum,

"New York, New Jersey, Minnesota, Illinois.-Poore, Charters and Constitutions.

${ }^{32}$ Formerly it was not necessary for the Speaker to vote to make a quorum. His presence was sufficient. - Cushing, Parliamentary Law, 12I-2.

s9 That this was the intention of the framers of the Constitution is shown by the following passage in the Federalist: "It has been said that more than a majority ought to have been required for a quorum. and in particular cases, if not in all, more than a majority of a quorum for a decision."-Federalist (Hamilton's edition), 446. 
but with the silent majority of the quorum. Bishop Stubbs applies the old maxim that " silence makes consent " to legislative bodies when he says: "The provision that the determination of the numbers present shall be regarded as the proceeding of the whole body summoned, enunciates in words the principle which had long been acted on, that absence, like silence, on such occasions implies consent." 34 It is true, as the minority asserted in regard to the dispute over the consideration of the Jackson-Smith election case, that if all the Republicans had been present they could have passed their measures in spite of any action of the Democrats. But it is also true that when all the Democrats were present they could defeat those measures by voting against them, since the Republicans during the first part of the session did not reach the full strength of their numbers. If it was a just demand that the Republicans bring in all their members when they wished to enact any legislation, a demand upon the Democrats to bring in all their members if they wished to defeat that legislation would also have been just. According to the minority in this contest, not only did the Constitution require a majority of the House to constitute a quorum, but the predominant political party must always be prepared to furnish that quorum. But the Constitution makes no such provision. A minority, moreover, should not be allowed more power by neglecting than by performing its duty. On one question in the House during the first session of the Fifty-first Congress, 163 members voted in

"Stubbs, Constitutional History of England, I, 566. 
the affirmative, and I 30 Democrats remained silent. Every one of those votes and 32 more could not have defeated the motion, and yet it was claimed that they could do by their silence what they could not by their votes. "To abstain seems less than to oppose," says Mr. Bryce, " yet under the method of resistance which Speaker Reed defeated, it would have counted for more." 35

Men cannot, moreover, be considered present for one thing and absent for another. ${ }^{36}$ It would seem that a member is participating in the business of the House who moves the yeas and nays, and the moment the roll-call is ended is on his feet claiming that there is no constitutional quorum. What is the logical conclusion of the position which the Democrats took? Members who are protesting that they are absent should not be allowed to make motions, and otherwise participate in the business of the House. If the right to count a quorum be denied, neither the Constitution nor parliamentary law nor the rules of the House are any check upon the will of the minority. It is unlimited in its power.

It was claimed that the question of deciding the ssg. The roll- presence of a quorum is beyond all call not the debate, since the roll-call is the only test of a quo- method known to the Constitution. rum. The Constitution indeed allows the yeas

\section{${ }^{85}$ North American Review, CLI, 395}

se June 8 , I864, a rule was passed that those not voting should be recorded in the Journal after those voting.-Cong. Globe, 38 Cong. I Sess., 2809. But this list was to include those absent as well as those silent in the House. 
and nays, on the demand of one-fifth of a quorum, to be entered on the Journal. ${ }^{37}$ But the record of a vote thus secured is not for the purpose of determining the presence or absence of a quorum. There is nothing in the Constitution which justifies such an assumption. If the framers of the Constitution had intended that a quorum should be determined by yeas and nays, there was no reason why they should not have plainly expressed their intention. The original and only object sought to be attained by this provision was that members should be required to show their constituents how they voted in order that they might be held accountable for such votes. ${ }^{38}$ Gradually, however, the roll-call became recognized in the House of Representatives as the test of the presence or absence of a quorum. This later and entirely secondary use was based upon the assumption that no other count could be more accurate. If every member responded to his name this assumption would be true; whenever the call is ignored by members, it fails as a test, and has no claim to further use for that purpose.

The refusal of members to vote is in direct violation of one of the oldest rules of the House. ${ }^{39}$ Whenever members ask to be excused from voting,

\section{${ }^{37}$ Constitution, I, 5.}

${ }^{38}$ Judge Story says, "The object of the whole clause is to insure publicity to the proceedings of the Legislature, and a correspondent responsibility of the members to their Constituents."-Commentaries on the Constitution, $\$ 840$.

${ }^{30}$ Appendix D, Rule VIII, I; adopted April 7, r789. "In the House of Commons every member must give his vote the one way or the other." Jefferson, Manual, § XLI. 
they recognize the validity of this rule by admitting that they have no right to refuse their names

120. Rules of the House of Representatives.

without excuse. Every member of the House of Representatives is, moreover, under strong moral obligation to obey the rules requiring him to vote. His acceptance of his trust and especially his oath of office make it incumbent upon him to discharge the duty of voting, or at least to help to make up that number by which alone business can be accomplished. Mr. Carlisle, to be sure, says that members are responsible to their constituents, and not to the House, when they refuse to vote in order to destroy a quorum. ${ }^{40}$ Whatever the theory of the relation between representatives and constituents, members owe something to the House to which they have been elected; and it is to the House and not to any remote constituency that they are responsible for a disobedience of its rules.

For the counting of a quorum in the House Mr. Reed appealed to some precedents in the rulings of 322. Rulings of other presiding officers. In 1874 Hon. other presiding John E. Sanford, then Speaker of the officers.

Massachusetts House of Representatives, made the following ruling: "It is not necessary to a valid decision of a question that a quorum shall vote, if the requisite number be present." 41 When in $1883 \mathrm{Mr}$. David B. Hill, as LieutenantGovernor, presided over the Senate of New York, he made a similar decision: the State constitution

\footnotetext{
${ }^{40}$ Cong. Record, 5I Cong. I Sess., 925.

"Massachusetts House Fournal, 1874, 564.
} 
required a three-fifths quorum to pass the bill under consideration; the requisite quorum was present, but would not vote; under these circumstances Mr. Hill ruled that the constitutional provision was entirely satisfied by the presence of the members even if they did not vote, and accordingly directed their names to be taken down as a part of the transaction. ${ }^{42}$ This decision was soon repeated in Tennessee: in the legislature of 1885 a registration bill was pending which was objected to by the Republican members of the House; upon the third reading they refused to vote; the Speaker, a member of the other party, therefore directed the Clerk to record as present those not voting, and declared the bill passed upon that reading. ${ }^{43}$ A similar point of order was raised during the same year in the Massachusetts Senate: the President, Mr. Pillsbury, decided it immaterial whether a quorum vote if a quorum be present, and held that the point of order that a quorum has not voted can be entertained, if at all, only so far as to ascertain whether a quorum is present. ${ }^{4}$ In 1889 this principle was incorporated into the joint rules of the legislature of Massachusetts. The reductio ad absurdum of " the doctrine of constructive absence" was reached in a case which occurred in the Pennsylvania Senate of 1880 . It is thus described: "There had been

${ }^{42}$ Cong. Record, 5I Cong. I Sess., 916.

${ }^{4}$ Cong. Record, 5 I Cong. I Sess., 916.

14 Similar decisions have been made in the New Hampshire House of Representatives (Cong. Record, 51 Cong. I Sess., 1234) and Pennsylvania Senate (North American Review, CL, 388) and legislatures of Ohio and Indiana. (Cong. Record, 5 I Cong. I Sess., I162.) 
much filibustering of the congressional sort during the session, the Democrats refusing to vote. Senator Rayburn, in the chair, decided that those Democrats who demanded the yeas and nays were present. There was much dissatisfaction, and one day when a Democrat was in the chair the same question arose, and he promptly decided that those who demanded the yeas and nays were not there. Thereupon the friends of tyranny of that period, in the person of $\mathrm{Mr}$. Cooper, made the point that the Chair was present, and the Chair decided that he was not. It was felt, however, that the great principle had somehow or other then and there received a great strain, and the Senate thereafter behaved and obstruction ceased." 45

Precedents set by presiding officers of legislative assemblies have less force because often made as a 222. Decisions piece of party tactics. Decisions of of English and the courts, English and American, have State courts. perhaps more weight. Lord Mansfield decided in 1760 , "Whenever electors are present and do not vote at all, they virtually acquiesce in the election made by those who do." ${ }^{46}$ Many instances of similar decisions by American courts were given in the discussion upon the subject in the Fifty-first Congress, ${ }^{47}$ and although these decisions applied either to private corporations, as gas companies and colleges, or to municipal corporations, the principle is the same.

4b T. B. Reed, North American Review, CL, 388.

"Cong. Record, $5 \mathrm{I}$ Cong. I Sess., 1230.

"See Cong. Record, 5 I Cong. I Sess., Ir57-r161, 1230-1234. 
In the practice of previous Houses of Congress there is some precedent for the counting of a quorum.

123. Precedents of the House of Representatives.

In the Twenty-seventh Congress the Speaker overruled the point of order that there could be no decision without a quorum voting, and on the ground that there was evidently a quorum in the House declared the question decided. ${ }^{48}$ Votes showing obviously no quorum have been constantly announced from the chair, and no persistent objection was made until not voting was used as a method of obstruction. Mr. Carlisle's refusal, however, to announce such a vote taken by yeas and nays is interesting: the vote having been taken on a certain bill with the result, yeas 145 , nays 6 , not voting I72, Speaker Carlisle announced that no quorum had voted and that the bill had not passed; upon the point being raised that the objection of no quorum had not been made, the Speaker decided that when a vote was taken by yeas and nays, it was the duty of the Chair to take notice of the fact that a quorum had not voted, and that the bill had not passed by a constitutional vote. ${ }^{49}$

An objection is made by some who do not insist on the roll-call as the only mode of showing the presence of a quorum, that the count ought not to be made by the Speaker. It is true that such authority is nowhere given him; yet in the House of Commons it is the Speaker who counts to see if the 48 Cong. Globe, 27 Cong. 2 Sess., 979. See also Cong. Globe, 28 Cong. 2 Sess., 393.

40use Journal, 48 Cong. I Sess., I385-6. 
necessary forty members are present; ${ }^{50}$ and the general principle was laid down by Cushing long before this controversy, as follows: "The quorum of each legislature becomes established at a fixed number, the presence or absence of which can always be ascertained by counting. This is usually done after the assembly is constituted, by its presiding officer, who announces or reports the result." ${ }_{51}$ And further, "If it appears upon a division, or if notice be taken by any member that a quorum is not present, it will become the immediate duty of the presiding officer to count the members, and if they do not amount to a quorum, to suspend all further proceedings until the requisite number comes in, or to adjourn the assembly without a question until the next sitting day." ${ }_{52}$ In all American parliamentary meetings the chairman calls to order after the evidence of his own senses has shown a quorum to be present. Where there is no special arrangement for determining a quorum, therefore, the presumption would be that it rests with the presiding officer.

In addition to the practice of English and American assemblies, the rules of the House of Representatives have long recognized and invested in the presiding officer the power in certain instances to

"0 May, Parliamentary Law, 2xx. "Except at the beginning of each day, however, he may not count the House, of his own accord, not unless his attention is called to the absence of a quorum by some other member." This is also the practice of several foreign assemblies. Dickinson, Procedure of Foreign Parliaments, 206, 248, 274.

${ }^{6}$ Cushing, Parliamentary Law, \$253.

${ }^{62}$ Cushing, Parliamentary Law, $\$ 369$. 
make an actual count of the persons present. It is provided, for instance, that a call of the House shall not be allowed after the previous question is ordered unless it shall appear upon an actual count by the Speaker that a quorum is not present..$^{53}$ If a quorum does not appear in the Committee of the Whole, the committee rises and the Speaker counts the House. ${ }^{54}$ If business were done in the House of Representatives without a quorum, the Speaker would be held responsible: he knows whether or not a quorum is present by a count made by himself. Mr. Smith says: "The practice of counting the House by the Speaker of late years has frequently been resorted to to ascertain the presence of a quorum, and is a more expeditious way than the roll-call." ${ }_{55}$ On a rising vote it is always the duty of the Speaker to count. It is true that tellers can afterwards be demanded; still it is the Speaker who counts to see if they are demanded by the necessary one-fifth of a quorum, so that the Speaker is ultimately the counting officer.

The stock argument against the count of a quorum was that if the Speaker can judge of the presence of a quorum, there is no protection against his arbitrary counting, if he be a corrupt man who will count to suit his own aims. The opposition repeatedly raised the question: " Who is to control the Speaker's seeing ?" The only answer is: "The

${ }^{63}$ Appendix C, Rule XVII, 2. For example of a Speaker's action under this rule see Cong. Globe, 38 Cong. I Sess., 2892-3.

${ }^{54}$ Appendix D, Rule XXIII, 2.

${ }^{35}$ Smith, Digest, 296. 
majority, in sustaining or refusing to sustain his decisions."

None of the instances here given, however, affects the fact that there was no precedent in the practice of the House for counting a quorum in the face of opposition. For this step Mr. Reed took and accepted full responsibility, although it was doubtless agreed upon by a conclave of the leaders of his party.

Mr. Reed's second principle was that he would prevent obstruction by refusing to entertain dilatory 124. Ruling on motions. Under the general principles dilatory mo- of parliamentary law it has always been fied by partia- the Speaker's duty to arrest obstrucmentary law. tion when carried too far. According to Crocker the very definition of parliamentary law is "The system of conducting meetings so that the will of the majority shall be ascertained and expressed with accuracy, and with the utmost expedition consistent with fair and due debate." ${ }_{56}$ The first duty of the Speaker, therefore, is to see that this fundamental principle of all parliamentary law is executed. If the expression of the will of the majority is prevented by the obstruction of the minority, he should go to the extent of his power to prevent that obstruction.

It is objected that the Speaker has no authority 125. Rules and to decide what is and what is not obpractice of struction, since dilatory motions are in the House. themselves not different from any others; they are in form ordinary parliamentary motions.

${ }^{\infty}$ Crocker, Principles of Procedure, $\S \mathbf{I}$. 
For the Speaker to refuse to consider them because he deems them made for the purpose of delay, is to judge the motives of members. To this, the first objection raised against Mr. Reed's ruling, it may be answered that in certain instances the Speaker has always possessed the right. Jefferson's Manual requires the Speaker to direct a bill to be read upon the desire of any member, " if the request is really for information and not for delay." 57 A rule of the House adopted in 1868 forbids the Speaker, pending a motion to suspend the rules, to entertain any other dilatory motion, except one to adjourn. ${ }^{58}$ Under this rule, therefore, the Speaker has for some time been allowed "to judge the motives of men." In the Forty-third Congress Speaker Blaine stated:" The Chair has repeatedly ruled that pending a proposition to change the rules dilatory motions could not be entertained." 58 When in 1877 Mr. Randall refused to entertain dilatory motions during the count under the Electoral Commission act, he said: " The Chair desires to say to the House that he does not of course know what the intention of those motions is, he has only to look to the effect of them. The effect of these motions is dilatory, is delay; that is all that the Chair looks at, the effect of the motions; he criticises in no manner whatever

${ }^{57}$ Jefferson, Manual, $§ 32$.

Appendix D, Rule XVI, 8; adopted Feb. 25, 1868. Mr. Blaine ruled January 27,1875 , that pending a proposition to change a rule, no dilatory motion could be entertained.-Cong. Record, 43 Cong. 2 Sess., 1806.

Cong. Record, 43 Cong. 2 Sess., 806. 
the intentions or motives of the persons." ${ }^{5}$ In the Forty-seventh Congress a rule was adopted which prevented dilatory motions during the consideration of contested election cases. ${ }^{59 \mathrm{a}} \mathrm{Mr}$. Reed claimed, what was claimed by Mr. Robinson, of Massachusetts, in 1882 , that " motions made to block business are only a species of disorder, more difficult to deal with perhaps because they have the semblance of an honest performance, but like disorder in quality and substance." 60

Perhaps the real objection to Mr. Reed's decision, however, is the belief that a presiding officer should 126. Question of not be allowed the final voice in any the right of the matter, that a right to refuse dilatory Speaker to make final de- motions and to deny dilatory appeals cisions.

from the decision of the Chair makes the power of the Speaker absolute and produces a revolution in the practice of the House of Representatives. But the privilege of the Speaker to give final judgment on certain questions is not so novel as has been asserted, since the Speaker's power of recognition, a power of the greatest importance to the members of the House of Representatives, is now exercised practically without appeal..$^{61}$ No new danger is to be apprehended from the "new and absolute" power thus given to the Speaker. Nor is it true that Mr. Reed was the first Speaker to refuse to entertain appeals from the decision of

" Cong. Record, 44 Cong. 2 Sess., 4316.

soz Cong. Record, 47 Cong. I Sess., 4324.

"North American Review, CL, 540, May, 1890.

"See below, § 149 . 
the Chair. ${ }^{62}$ Whenever motions have been declared dilatory and hence out of order, Speakers have taken the responsibility of ignoring them. January 28, I863, Mr. Colfax, Speaker pro tem., said: "The Chair cannot receive an appeal. The Chair makes his decision subject to the censure of the House, but cannot receive the appeal." ${ }^{3}$ In the Fortythird Congress Speaker Blaine refused to receive any appeals pending a motion to suspend the rules. ${ }^{\text {st }}$ In 1882 , during the difficulties over a contested election case of that year, Mr. Reed made a point of order that upon a proposition that the House change its rules, dilatory motions could not be entertained by the Chair; the point was sustained by Speaker Keifer, ${ }^{65}$ and appeals demanded by $\mathrm{Mr}$. Springer were refused.

Mr. Reed has defended this power of the Speaker on the grounds that dilatory motions are easily distinguished from real, and that no Speaker would refuse to entertain a dilatcry motion until it was patent to all that it really was such. ${ }^{66}$ Nevertheless, Anglo-Saxons have been loath to allow to any presiding officers the power to make absolutely final decisions binding upon the House. And it is true that in conjunction with the enormous influence which the Speaker already possesses it is a power which might be abused. Its justification lies in

\footnotetext{
${ }^{22}$ See Cong. Globe, 27 Cong. 2 Sess., 925.

'2 Cong. Globe, 37 Cong. 3 Sess., 577.

a Cong. Record, 43 Cong. 2 Sess., 1747.

- Cong. Record, 47 Cong. I Sess., 4324.

${ }^{\circ}$ North American Reiticw, May, 1890.
} 
the absolute necessity that some one assure to the House the opportunity for the proper discharge of its functions.

The quorum decision and the decision on dilatory motions were both incorporated into the rules 327. Rules of adopted by the House after long debate 1890.

and vigorous opposition, February I4, 1890.67 Obstruction was further weakened by eliminating from the motions allowed when a question is under debate two propositions seldom used for any other purpose than delay, - those to take a recess, and to fix a day to which the House shall adjourn. ${ }^{68}$ The majority of the committee on Rules, in its report to the House, thus justifies the rules of 1890: "The abuse has grown to such proportions that the parliamentary law which governs American assemblies has found it necessary to keep pace with the evil, and to enable the majority by the intervention of the presiding officer to meet by extraordinary means the extraordinary abuse of power on the part sometimes of a very few members." ${ }^{69}$ The new rules while adding to the dignity

6r Cong. Record, 5 I Cong. I Sess., 1347. The new rules were as following: Rule XV,3, "On the demand of any member, or at the suggestion of the Speaker, the names of members sufficient to make a quorum in the Hall of the House who do not vote, shall be noted by the Clerk and recorded in the Journal, and reported to the Speaker with the names of the members voting, and be counted and announced in determining the presence of a quorum to do business." Rule XVI, Io, "No dilatory motion shall be entertained by the Speaker."

${ }^{86}$ Appendix D, Rule XVI, 4.

"Cong. Record, 5 I Cong. I Sess., II 3 I-2. 
of the House and the order and regularity of its proceedings, and promoting the reasonable expedition of business, fixed the responsibility for legislation, to a much greater degree than ever before, upon the majority. This was effected, however, by adding to the important prerogatives which the Speaker already possessed. Yet somewhere must be lodged the power to secure the time of the House for public business. Experience shows that it is safer to trust a Speaker with the power to check members than to give to members the opportunity to tie up the House and prevent the discussion of the national affairs.

After the decisions of Mr. Reed were accepted by the House as a part of the new code of rules, his action in counting a quorum and refusing dilatory motions was undoubtedly legitimate. The previous discussion refers only to his action before the adoption of the rules, and to the grounds which the majority of the Fifty-first Congress had for the apparent innovation which it made in parliamentary practice. Perhaps it would have been wiser for Mr. Reed to have avoided the appearance of evil by delaying his decisions until authorized by the rules. Without these decisions, however, it would have been difficult, on account of the narrow majority of the Republicans, to get such a novel code of rules through the House. Yet it might perhaps with a little patience have been accomplished; but patience would have delayed the party programme, and the Republicans, with Mr. Reed for a leader, were determined upon legislating. 
After Mr. Reed's decisions had been embodied in the rules, important legislation was carried through 128. Decision of by their aid. Among the acts thus SupremeCourt. passed was the "Dingley Worsted act."

A test case was brought before the Supreme Court on the ground that the act had not received a constitutional majority in the House. The following is Judge Brewer's summary of his decision: "Summing up this matter, this law is found in the Secretary of State's office, properly authenticated. If we appeal to the Journal of the House, we find that a majority of its members were present when the bill passed, a majority creating by the Constitution a quorum, with authority to act upon any measure; that the presence of that quorum was determined in accordance with a valid rule heretofore adopted by the House; and that of that quorum a majority voted in favor of that bill. It therefore legally passed the House, and the law as found in the office of the Secretary of State is beyond challenge." Thus the court sustained the validity of the act. But the question of the counting of the quorum before the rules were framed was not before the court. The judgment of the Supreme Court is, therefore, not a confirmation of the Speaker's counting a quorum as such; it is simply an assertion that the Constitution gives the House the power to make its own rules. ${ }^{30}$

Perhaps the best commentary on the controversy

${ }^{10} 144$ United States Reports, 9, October term, 1891. Judge Brewer does indeed make some attempt to justify the rule, but it has nothing to do with the real decision. See pp. 5-I r. 
over the Reed rules is the action of the two succeeding Congresses. The rule that no dilatory morag. Present tion should be received by the Speaker state of the was dropped in that express form; rules. but the principle fought for in the Fifty-first Congress was virtually conceded by the Fifty-second and Fifty-third Congresses, when the power to prevent obstruction was placed in the hands of the committee on Rules, of which the Speaker is the principal member. The rules of the Fifty-second Congress allowed that committee to bring in a motion to stop filibustering; the rules of the Fifty-third Congress went further and allowed this directory committee to retire at any time from the House. Thus when a filibuster rises to his feet the committee may leave the House and report a measure to silence him. The rule which allows the committee on Rules to fix an hour for a final vote on a pending question is another weapon against obstruction. Moreover, distinct clauses ${ }^{i 1}$ retain for the Speaker the right to judge of dilatory motions; this provision was a necessary part of the plan to increase the power of the committee on Rules, otherwise there was no assurance that it could get a vote on its reports. Whether these anti-filibustering methods are better than those of the Fifty-first Congress, it is not necessary to consider here. In one case the Speaker decided, no doubt taking the opinion of the other leaders of his party on fundamental questions; in the other it was the majority voting under the direction of the same leaders in a com${ }^{n}$ Appendix D, Rules XI, 57 ; XVI, 8. 
mittee on Rules, who had the decision. In practice there is not much difference between a majority silently sustaining a Speaker, and a majority voicing its support of the Speaker. Both instances are cases of Speaker rule.

The Fifty-second Congress censured the quorum rule by omitting it in the new code. After four months of the Fifty-third Congress had passed, however, and the Democrats had found themselves much hampered by the lack of this rule, all business often coming to a standstill, a rule was adopted that before every roll-call the Speaker should appoint two members, "one from each side of the pending question," who should take their places at the Clerk's desk and note those members present not responding to their names, in order to make a quorum. There are two differences between this rule and the rule of the Fifty-first Congress. Under the new regulation the possibility of the accusation of a party count is done away with, and further, as the count is made at the actual time of the roll-call, there can no longer be any theory of "constructive presence," - the theory by which Mr. Reed sometimes counted men as present at the roll-call whom he had seen present at the time of the vote with tellers, and who might by the time the roll was

"Cong. Record, 53 Cong. 2 Sess., 466o. Rule VIII was also amended so as to read: "Every member-shall vote on each question put-and on a roll-call, should he not vote, he shall answer present"-Cong. Record, 53 Cong. 2 Sess., 466o. It was hoped, Mr. Catchings said on introducing the report, that this amendment alone would be sufficient to produce the desired result. - Cons. Record, 53 Cong. 2 Sess., 4663. 
called be, as happened in one instance, a mile from the Capitol. These differences, however, are unimportant. The adoption of the quorum rule in the Fifty-third Congress practically ended the discussion over the methods of preventing obstruction in the House of Representatives. The writer has incorporated the discussion in this work only for its historical value. Both parties now seem agreed that members may no longer reap any advantage by refusing to vote; it is practically acknowledged that the day of dilatory motions is past. 


\section{CHAPTER VIII.}

\section{POWER THROUGH THE COMMITTEE SYSTEM.}

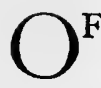

\section{Appoint-} ment of committees. 1

the Speaker's purely political duties the most important is the appointment of committees. The first committees of the House of Representatives were chosen by ballot. ${ }^{2}$ This method proved so inconvenient, however, that as early as January 18 , 1790, the selection was vested in the Speaker. ${ }^{3}$ It

1 The House of Commons appoints a committee of Selection and the committee of Selection appoints the committees.-S. Walpole, Electorate and the Legislature. In most of the European assemblies the House appoints the committees. See Dickinson, Procedure of . Foreign Parliaments.

- "The Speaker shall appoint committees unless it be determined by the House that the committee shall consist of more than three members, in which case the appointment shall be by ballot of the House." Rule adopted April 7, I789. Annals of Cong., I Cong. I Sess., 99. The most important committees consisted of more than three members.

" Ordered, That so much of the Standing Rules of this House, as directs the mode of appointing committees, be rescinded, and that hereafter it be a standing rule of the House, that all committees shall be appointed by the Speaker, unless otherwise specially directed by the House, in which case they shall be appointed by ballot; and if, upon such ballot, the number required shall not be elected by a majority of the votes given, the House shall proceed to a second ballot, in which a plurality of votes shall prevail: and in case a greater number than are required to compose or complete the committee shall have an equal number of votes, the House shall proceed to a further ballot or ballots."-Annals of Congress, I Cong. 2 Sess., ro56. 
was for many years the practice of the House to adopt an order at the beginning of each session, "That the Speaker be authorized to appoint the regular standing committees." 4 But since 1860 no such formal action has been taken; the Speaker has framed and announced the committees under the authority of the previous standing rule, ${ }^{5}$ for it is customary to adopt the rules of the previous Congress until a new code can be reported and accepted. In the Fifty-first Congress (1889), however, when this course had not been adopted by the House, the Speaker designated the committees under the authority of a special resolution reported from the committee on Rules and accepted by the House. ${ }^{6}$ Since 1861 , moreover, the term of the committees has been no longer for the session only, but for the whole Congress. ${ }^{7}$ Although this change tended somewhat to lessen the Speaker's control over the committees, that control has in other ways

- See Journals.

"In the Thirty-seventh Congress, which met in I86r, Colfax moved the usual resolution, but Speaker Grow replied: "The Chair will state that, by the standing rules of the House, the Speaker is authorized to appoint the committees."-Cong. Globe, 37 Cong. I Sess., Io.

"Cong. Record, 5I Cong. I Sess., 130. In the Forty-first Congress the Speaker's power was further increased by the following rule: "Resolved, That the Speaker be authorized, at his discretion, to assign the representatives admitted to their seats since the organization of the present Congress to any of the Standing or Select Committees as additional members thereof : Provided, That this shall not be construed as changing the rule of the House limiting the number of each committee except for the present Congress."-House Journah, $4^{\mathrm{r}}$ Cong. 2 Sess., 39. Dec. 9, 1869.

'Cong. Globe, 36 Cong. I Sess., Ir $8 \mathrm{I}$, 
been more than correspondingly increased. The only exception to the method of selection has been the case of those committees in whose reports the Speaker might have a personal interest. During the first half century it was usual for such committees to be chosen by the House, ${ }^{8}$ but in 1843 the practice was changed. In that year the seat of Jones was contested; he, therefore, asked to be relieved from the duty of naming the committee on Elections. It was suggested that the appointment be given to the Speaker pro tem., although it was pointed out that if there was any impropriety in the construction of the committee by the Speaker, there was exactly the same impropriety in its construction by a Speaker pro tem. created by him; the motion was, however, carried. ${ }^{9}$ The precedent thus established has since been followed. The Speaker of course chooses a political friend to act as his substitute.

To the Speaker has also fallen by long established usage the appointment of the chairmen of the committees. He obtains this privilege ryx. Chairmen through the custom of permitting the
of committees. first named on a committee to act as presiding officer. For a long time the privilege has been embodied in the rules of the House; at first it rested only on custom. "This is a matter of courtesy;" we read in Jefferson's Manual, " every committee having a right to elect their own chairman." In 1804, however, an incident occurred which caused

${ }^{-}$See Cong. Debates, 18 Cong. 2 Sess., 44I, 486.

- Cong. Globe, 28 Cong. I Sess., 21. 
this privilege to be definitely included in the rules. The chairman of the committee on Claims having resigned, the committee chose Mr. Samuel W. Dana to take his place. Mr. Dana refused, and the matter came before the House and was referred to a special committee. The committee recommended that the first named member be the chairman, and in case of his absence or of his being excused by the House, the committee should elect a temporary presiding officer by a majority of its votes. The House rejected this proposition. The next day the committee on Claims notified the House that unless some action were taken in the matter, no business could be done by the committee during the session. The House, therefore, adopted in a modified form the rule as reported by the select committee. ${ }^{10}$ The committee on Claims elected Mr. Dana its chairman, and much against his wishes he was obliged to serve. ${ }^{11}$

The original principle of congressional committees seems to have been that they should form im132. Manner in partial boards of investigation. The which the inevitable tendency of possible power Speaker's pre-
rogative is ex- to become actual power could scarcely ercised. have been taken into account in 1789 . From the beginning the committees were not im-

10 " That the first named member of any committee appointed by. the Speaker or the House shall be the chairman, and in case of his: absence or being excused by the House the next named member, and so on, as often as the case shall happen, unless the committee shall, by a majority of their number, elect a chairman."-Annals of Cong... 8 Cong. 2 Sess., 699.

"Smith, Digest, twelfth edition, 304-5. 
partial, and not boards of investigation: even the earliest were constituted to a considerable extent on party lines or personal prejudice. In I791, for instance, the Speaker was ordered to appoint a committee to see what could be done constitutionally to limit the slave trade and ameliorate the condition of the slaves; it was to consist of five members: all its members were either pro-slavery men or indifferent on the question. ${ }^{12}$ It has been, in fact, all but universally acknowledged that the Speaker's first thought in the construction of the committees should be the interests of his party. An ardent writer places the order of the Speaker's duties in appointing committees as follows: "He must be pledged to nothing but his duty to Democratic principles, and the welfare of the whole country." But factions very early grew up within our parties, and have always continued to prevent harmonious, concerted action: to say nothing of internal divisions on the slavery question, there have long been marked differences of opinion in both the great parties on the tariff and other fiscal questions. Since the Speaker always owes his election to the dominant faction of his own party, ${ }^{13}$ he naturally gives to that faction the preference in the construction of the committees. Thus this officer has not had to respond to the pressure of a united party, but to balance the claims of the different divisions of the party. Often the majority is nearly evenly divided on a certain question; the Speaker may

\footnotetext{
"Annals of Cong., 2 Cong. I Sess., 241.

${ }^{23}$ See above, $\$ 29$.
} 
then very easily make up the committees to represent his own views and thus increase his personal influence. Lately, moreover, there has grown up the theory, among the Speakers at least, that the Chair has the right to have and to pursue a policy of its own; so that recent occupants of the office have been known to accomplish their ends in direct opposition to what has seemed, so far as could be estimated, the predominant opinions of their party. The acceptance of the new doctrine will depend on the degree to which the necessity of a central guiding hand in legislation is realized.

This great appointing power cannot, however, be exercised with entire freedom. The construction of

133. Restrictions in the use of the prerogative.

the committees is a duty requiring the utmost caution and deliberation. In it is involved a multitude of considerations. There is a body of three hundred and sixty men to choose from, and about five hundred places to fill. The theoretical and ideal principle of the Speaker is to utilize the ability of these three hundred and sixty persons to the best advantage, but this can hardly be recognized as an actual governing motive. What this officer does attempt to do is so to balance the various considerations as to accomplish his own aims, please his party, satisfy individuals, meet the reasonable expectations of the minority, and appear respectable to the country-a laborious task greatly increased by the large number of new men and the importunity of members for particular places. First among influential considerations are the numerous claims 
which have grown out of his election: he must remember the men who have voted for him in the party caucus, he must recognize the preferences of his party as expressed in the other nominations for the Speakership, and he must redeem the promises by which he has secured his choice. $\mathrm{He}$ should always take great care to avoid alarming particular interests. It will hardly be wise to disregard important groups of men. And custom obliges him to recognize peculiar ability and reputation as well as long service. ${ }^{14}$ Usage sanctions also a system of promotions in the appointment of the committees. Party standing as well as party services must be carefully considered. It is necessary also to balance the relative strength of the delegation from each State. Sectional interests and local vanity must always be remembered: New York, for instance, must be represented on the Commerce committee, as Pennsylvania and New England on the committee of Ways and Means. Too many members cannot be taken from one or a few States, else the neglected States will be heard in loud complaint; the representative men of a section, more-

14 None of these unwritten laws, however, have ever been universally followed. In I8or, according to Adams, the oldest members of much authority, William B. Giles of Virginia, and Samuel Smith of Maryland, were passed over for a favorite of Speaker Macon's. Young John Randolph, barely twenty-eight and just beginning his congressional career, was placed at the head of the Ways and Means committee. Smith was made chairman of the committee on Commerce, while Giles was quite neglected.-Adams, United States, I, 267-269. For appointment of committees, see Annals of Cong., 7 Cong. I Sess., 312. 
over, must be chosen for a committee which has great influence over its interests: sectional feeling runs high in the House of Representatives; there is indeed no limit to the care which the Speaker has to take not to run counter to this feeling; sectional composition of committees has always been a subject of complaint. One of the minor reasons for the selection of Mr. Springer as chairman of the Ways and Means in I89I was the fact of his being a Northern man: to have allowed the tariff bill to be framed by a Southerner would only have put one more article of denunciation in the mouths of the Republicans.

When the Speaker and the President are of the same party, the Speaker often tries to appoint chairmen acceptable to the President and the Cabinet on those committees which act as organs of communication with the Executive. This consideration had more weight in the early years of Congress when the relations between the Cabinet and the committees were closer than they are now. Thus Gallatin complained in 1807, "Varnum has removed Randolph from the Ways and Means much against my wishes." 15 And John Quincy Adams says in his Memoirs, "Peters said he had talked last evening with Stevenson, the Speaker, who told him that his reason for not appointing me Chairman of the Committee of Foreign Relations was that I was in no personal relations with the President." 16 In I841 Speaker White intended to make Adams chairman of the commit-

"Henry Adams, United States, II, I53.

John Quincy Adams, Memoirs, VIII, 454; January 7, 1832. 
tee of Foreign Relations, and indeed had asked him if he would be willing to serve in that capacity, and had received his assent ; but he appointed Caleb Cushing instead "at the special request of Mr. Webster," Secretary of State. ${ }^{17}$ White's pliancy to Webster's wishes, however, cannot be taken so much as evidence of his zeal for smooth-running machinery of state, as a sign of his willing subserviency to those whom he acknowledged his masters.

The Speaker always feels a sense of obligation to his party: a Democratic Speaker must not offend the Democrats of a certain section just before a Presidential election. And he is expected to remember the wishes of the party in his own State. ${ }^{18}$ Here as elsewhere, moreover, there is a distinct line between "partisan" and "political" action. The Speaker cannot cross that line without severe condemnation: he must take care to give the minority a fair representation both in numbers and strength: it is true that the dominant party has always a majority on every committee; ${ }^{19}$ but the traditions of the House prevent that majority from being such as entirely to swamp the minority.

17. John Quincy Adams, Memoirs, X, 54I.

Mr. Randall's position in 1877 was one of great delicacy, for the Pennsylvania Democrats demanded a protective tariff, the repeal of the Resumption act, and liberal appropriations for internal improvements.

${ }^{10} \mathrm{Mr}$. Speaker Hunter, in his farewell speech in $184 \mathrm{I}$, gave the reason for this. "The party upon which it naturally devolves to propose a question," he said, "ought to have the power, it would seem, to present its proposition in the shape for which it is willing to be responsible."-Cong. Globe, 26 Cong. 2 Sess., 239. 
This is a result of the fundamental idea of committces, already mentioned, that they should constitute impartial boards of investigation. The proportions between the different parties on the committees usually follow, therefore, the proportion between the parties in the House: when any great change takes place in the House there is a corresponding change on the committees. Much complaint used to be made, with more or less justification, of an insufficient minority representation on the committees; but now the relation between the numbers on the committees and the numbers in the House has become more settled. The Speaker often consults the chairmen in regard to the composition of their respective committees: thus John Quincy Adams tells us that Polk sometimes asked him if he was suited with his committee. ${ }^{20}$

It was formerly customary for the Speaker to give his predecessor some important chairmanship. Until late years it has been also the practice, whenever there have been particularly eminent men among the minority, to give them chairmanships. In I823 Clay placed Daniel Webster at the head of the important committee on Judiciary. John Quincy Adams was chairman of some committee during nearly the whole of his service in the House, although he was usually in opposition to the Speaker. In $1856 \mathrm{Mr}$. Davis could not slight such a statesman as Governor Vance, of Ohio, and he was given the committee on Claims. When in 1857 Mr. Giddings, the oldest member of the House, was ${ }^{20} \mathrm{John}$ Quincy Adams, Memoirs, X, 58, 176-177. 
taken from the committee on Territories, the Speaker's action was severely criticised. But at that time the committee on Territories was very important; the change was probably made by Mr. Orr in order that the Kansas bill might be brought forward with more safety; thus mere courtesy seldom stands against strong political feeling. General Banks, chosen to the chair in 1855 , was elected by a plurality vote: under the peculiar circumstances of his election, therefore, he felt it to be his duty to exercise special care and impartiality in the make-up of the committees; he accordingly gave several chairmanships to his opponents, and allowed them in general unusual strength on the committees. Now, however, chairmanships are never given to the minority; they are considered the legitimate accompaniment of power.

The difficulty in constructing the committees is greatly increased by the fact that these various considerations often conflict. Thus perhaps the last place on a committee should be given to a man from New England; it may also seem necessary to give it to a Republican; but there may be no Republicans from New England left who are suited to this committee. In the Forty-eighth Congress Mr. Carlisle was denounced by some of his opponents for what was called the sectional composition of the committees, which meant that the South had the leading chairmanships. But Mr. Carlisle could not avoid this arrangement: the House was Democratic, and the ablest Democrats were from the South. 
The importance of the Speaker's appointment of the committees is greatly increased by the fact that

134. Irresponsiit is an absolute power: there is no bility of the Speaker's power.

provision which requires that the committees be approved, and as a matter of fact, the House never questions an appointment. And the Speaker, in spite of the restrictions on his prerogatives, has many opportunities to constitute the committees so that he may to a great extent procure or prevent what legislation he wishes: he may give a good committee to a poor chairman; or he may satisfy the general feeling in the appointment of a chairman, and then give him a committee which reflects the Speaker's, not the chairman's views, and with which, therefore, the chairman cannot act. In 1871 Blaine appointed Butler chairman of a committee on the Ku Klux outrages much against his will, as the committee was so constituted that it would wish to bring in entirely different measures on reconstruction from those favored by Butler. Butler accused Blaine of having appointed him chairman against his wishes, to which the Speaker replied: "Because I knew very well that if I omitted to appoint the gentleman it would be heralded throughout the length and the breadth of the country . . . that the Speaker had packed the committee . . . with ' weak-kneed Republicans,' who would not go into an investigation so vigorously as he would. That was the reason." 2

How much bargaining there is in the make-up of

"March 16, 1871. Cong. Globe, 42 Cong. I Sess., 124. Butler was afterwards excused.-Cong. Globe, 42 Cong. I Sess., 130. 
the committees does not appear upon the surface. It is currently believed that Speakers often appoint chairmen with the understanding that they shall or shall not introduce certain measures. Mr. Carlisle was charged in 1883 with appointing Mr. Buckner head of the committee on Banking and Currency, and Mr. Bland head of the Coinage committee, only on " their personal assurance to Mr. Carlisle that they would not attempt to bring in such bills as they would otherwise be expected to bring in; Mr. Buckner on condition that he would not make war on the National Bank system nor indulge in any crazy vagaries about the currency. Mr. Bland promised not to force any of his unlimited silver schemes on the country." 2

The Speaker has an opportunity to help his party in determining the relative strength of the two parties on a committee: he can put the strong men of the minority on the committees which have little influence, and the weak men of the minority on the powerful committees. Thus John Quincy Adams once accused the Speaker of giving him a better committee than at the previous session, "because there will be nothing of importance for that committee to do the present session." Or the Speaker can place men on committees where the questions involved are those of which they have but little knowledge. To act thus would be glaringly unfair. If the minority is to be given any place on an important committee it is only just that it should be represented by its ablest men. Still ${ }^{29}$ New York Tribune, Dec. 29, 1883. 
there are many shades of fairness and unfairness, and Speakers have sometimes attempted, without incurring particular odium, to minimize the influence to which a minority was justly entitled by the power and ability in its ranks. Probably no Speaker ever so organized the committees as to secure their full proportionate influence to members of the minority. The Speakers who come near it are called fair. Those who do not are called unfair and partisan. Legislation may be easily prevented by so balancing a committee that it cannot act.

There may, to be sure; be several subjects in which the Speaker is interested, which must be referred to the same committee. It may be impossible to constitute one which shall agree with him on these various subjects. He will have, therefore, to construct a committee which will introduce the legislation he wishes upon one of the subjects, and sacrifice his other interests. Still it may be said that it is possible for the. Speaker to have a legislative policy and to put it into operation through the construction of the committees. Some men indeed have not sufficient energy to do the most with their opportunities: instead of making it their chief object to carry out a policy of their own, they yield first to the pressure of one faction and form one committee to act in a particular way, and then under the influence of another faction appoint a second committee which may report legislation of an entirely different kind. The committees are thus made more disconnected and antagonistic than they naturally are, and the dispatch of busi- 
ness is greatly hindered. Much more than honesty and a desire to advance the welfare of the country is needed in the construction of the committees: the Speaker must be not only a parliamentarian but a man of power and of statesmanlike capacity.

Since the construction of the committees is in itself an index to the legislation of the next two 135. Announce- years, their announcement is waited ment of com- for most eagerly. In the early Conmittees.

gresses the committees were completed within a few days of the opening of the session: it was the custom of the House to adjourn in order to give the Speaker time to consider the matter. With the increased difficulty, however, in making the appointments, the time that elapses between the assembling of Congress and the announcement of the committees has also increased. When there is a preliminary " extra" session, the committees, with the exception of those absolutely necessary, are not announced until the " second," that is the regular December session. There has been considerable complaint against any delay. In $187 \mathrm{I}$ a resolution was introduced that the standing committees be immediately announced; but the Speaker, Mr. Blaine, spoke against its adoption: he said that it was necessary to wait in order to get acquainted with the new members; that in the previous Congress he had made the announcement eleven days after the session had opened, and consequently had made several mistakes. The resolution was laid on the table. ${ }^{23}$ In 1887 again it was moved that the "Cong. Record, 42 Cong. I Sess., 16-19. 
Speaker be required to appoint the standing committees within two weeks after the beginning of Congress. ${ }^{24}$ The organization of Congress is not final, and nothing can really be accomplished until after the appointment of these bodies. The House is therefore naturally restless under any delay that is considered unnecessary. Yet not only is time to consider claims required, but time to make acquaintance with members. Mr. Reed is reported to have accounted for the McKinley tariff of 1890 by the fact that one of the members of the Ways and Means had other views than he had supposed. Since the legislation of the session depends upon the make-up of the committees, and since political and practical considerations have such weight, announcements are now rarely made earlier than Christmas, three weeks after the beginning of the session.

After the committees are all appointed, changes in membership are infrequent and cannot be compelled. The House may and does excuse mem136. Change or removal of bers, but the Speaker cannot do so. ${ }^{25}$ committee. The theory is that the Speaker ap-
men.

points the committees for the House. When in 1831 a new tariff bill seemed impending, John Quincy Adams relates that he "had asked Mr. Everett to consent to exchange places with me on the committees-to take my place as Chairman

" Cong. Record, 50 Cong. I Sess., III.

${ }^{25}$ In the 36 th Congress a debate arose on the right of a member to be excused from serving on a committee, and it was decided in the negative; vote. Ioo-100. Cong. Globe, 36 Cong. 2 Sess., 59-6r. See Cong. Record, 5 I Cong. I Sess., 379, for example of a member excused from serving on a committee. 
of the Committee of Manufactures, and to give me that of second upon the Committee of Foreign Relations, where he was placed; to which he readily agreed if the Speaker (Stevenson) would consent, which he said he did not believe he would. After the adjournment I went into the Speaker's chamber and proposed to him to authorize the exchange; but he said he had no power to make the alteration; that the appointment of committees being once made was the act of the House, he had no authority to change the arrangement in any manner. . . He repeated . . . that the House alone could excuse me; and if they should, another distinguished citizen from the East would be appointed, but not Mr. Everett." ${ }^{26}$ Thus the theory seems to have been that while the appointment of the committees was delegated to the Speaker, he thereby exhausts his authority, and that changes and removals are still the province of the House.

In appointing special committees parliamentary law demands that the Speaker shall be guided by the views of the House as expressed in 337. Special the vote which calls for the appoint-
committees. ment: ${ }^{27}$ if the House orders that a thing shall be done the Speaker should so compose the committee that it will be done. In 1858 oc-

${ }^{26}$ John Quincy Adams, Memoirs, VIII, 436-7; Dec. 13, 1831.

${ }^{27}$ Jefferson says, " Those who take exceptions to some particulars in the bill are to be of the committee, but none who speak directly against the body of the bill; for he who would totally destroy will not amend it-or as it is said (5 Grey I45), the child is not to be put to a nurse who cares not for it (5 Grey 373)."-Jefferson, Manual, $\S$ XXVI. 
curred a remarkable violation of this principle. By a vote of II 5 to II I the House directed the appointment of a select committee of fifteen members with instructions to inquire into all the facts connected with the formation of the Lecompton Constitution, the enactment of the laws under which it was originated, the facts and proceedings which had transpired since its formation, and whether it was acceptable to a majority of the legal voters of Kansas. ${ }^{28}$ The committee was in fact to investigate the whole matter thoroughly, and a majority of it ought to have been chosen out of those favorable to the investigation; $\mathrm{Mr}$. Orr placed upon it eight men who had voted against, and seven men who had voted for the investigation. ${ }^{29}$ The result of the deliberations is interesting: Mr. Harris reported on the part of the minority " that in their opinion said committee had failed and refused to execute the order of the House contained in the resolution for their appointment and has adjourned sine die." The committee had indeed refused to investigate the facts; but $\mathrm{Mr}$. Orr ruled that a minority has no right to make a report unless there be also a majority report, ${ }^{30}$ not even to complain of the refusal of the majority to obey its instructions.

One of the difficulties in the way of creating select committees is brought out by a complaint of John Quincy Adams in 1835: "The greatest injury he

${ }^{28}$ Cong. Globe, 35 Cong. I Sess., 622-633.

${ }^{29}$ Cong. Globe, 35 Cong. I Sess., 679.

${ }^{30}$ Cong. Globe, 35 Cong. I Sess., I075. 
[the Speaker] has done me was by appointing me chairman of the committee on the bill from the Senate fixing the northern boundary of the States of Ohio, Indiana, and Illinois-a service which it was impossible for me honestly to perform without indisposing bitterly against me three whole States of the Union and twenty-nine members, their Representatives in the House." ${ }^{31}$ The general custom is to make the member upon whose motion a select committee is appointed the chairman of that committee: thus in the instance just cited Mr. Harris would have offered his motion as an amendment to one previously introduced, if he had not feared that in that case the member who had made the first motion, and not he, would have got the chairmanship of the committee. ${ }^{32}$

As the custom of allowing the Speaker to appoint the committees rests on nothing more binding than

138. Attempts to transfer to the House the appointment of the committees. the rules of the House, subject at any time to change by a majority vote, it is somewhat surprising that his power has continued with so little question. A number of propositions have been made for a different constitution of the committee on Elections, ${ }^{33}$ and it has also been several times suggested that all the committees be appointed by ballot. $^{\text {.4 }}$ Such resolutions were unsuccessfully brought

"John Quincy Adams, Memoirs, IX, 214.

${ }^{32}$ Cong. Globe, 35 Cong. I Sess., 597.

ss House Journal, 25 Cong. 3 Sess., 403 ; 26 Cong. I Sess., 382 ; 4 I Cong. 2 Sess., 321 ; 49 Cong. 2 Sess., 212.

* There have been other plans outside the House for appointing 
forward in $1804,,^{35} 1806,,^{36} 1807,,^{37}$ and again in $1809.0^{38}$ On one motion Mr. Lyon said that such a method would be more respectful to the nation, and that the persons so appointed would feel a greater responsibility to the House. Mr. Gardiner supported the motion and asserted that he was in favor of it on the principle of this government that the many ruled, in contradistinction to that of monarchical or aristocratical governments where one or a few bore sway. ${ }^{39}$ For twenty-three years the question lay dormant, but in 1832 a resolution was introduced that the committee in regard to a National Bank should be chosen by ballot; it was decided in the negative by the Speaker's casting-vote. ${ }^{40}$ In 1838 there was an "attempt to get the committee on Elections chosen fairly and impartially" by a somewhat elaborate election by lot; $;^{41}$ the attempt failed, as did a similar one in the next Congress. ${ }^{42}$ In 1849 after the long contested election and the final choice of Speaker by a plurality vote, it was but natural that some one should propose the appointment of

the committees, as for instance the one by which the Speaker and leading chairman combine to appoint the other committees.-Nation, XLVI, 28-9.

${ }^{36}$ That the committees be appointed by ballot, and after being met, they should choose their own chairman.-Nov. 22, r804.-Annals of Cong., 8 Cong. 2 Sess., 698.

${ }^{36}$ Annals of Congress, 9 Cong. 2 Sess., rix.

${ }^{37}$ Annals of Congress, ro Cong. I Sess., 789-793.

${ }^{38}$ Annals of Congress, Ix Cong. I Sess., 58.

39 Annals of Cong., I I Cong. I Sess., 58-59.

40 See above, $\S 48$.

${ }^{11}$ House Journal, 25 Cong. 2 Sess.,, 533.

${ }^{42}$ House Journal, 26 Cong. r Sess., 382. 
the committees by the House. ${ }^{43}$ Again, thirty years later, the proposition was renewed: in I880 Mr. Gillette proposed an amendment to the rules that " no Speaker shall be authorized to construct the committees of any future Congress without direct authority by vote of the House of Representatives;" he thought it consistent with the Republican mode of proceeding and thinking, and proper for this country, that on all practical occasions this rule should be regarded where the many were as competent as the few or the one; and without meaning the least disrespect to the present Speaker, he conceived that the members of this House were as competent to choose their own organs as the Speaker, whoever might fill the chair. ${ }^{4}$ His argument was that the uncertainty which would thus attend the prerogative would " prevent committee appointments being used as a legal tender to purchase election."

January II, I882, Mr. Orth moved that the committee on Reform in the Civil Service be "instructed to inquire into the expediency of providing a mode different from the present for the appointment of the committees of the House, with leave to report at any time." 45 The Speaker said that the resolution must be referred to the committee on Rules, and on an appeal to the House his decision was sustained. In the same year it was again sug-

49 Cong. Globe, 31 Cong. I Sess., 79.

"Cong. Record, 46 Cong. 2 Sess., I 207.

45 Coy. Record, 47 Cong. I Sess., 358. He had said when giving mtention of introducing the resolution, " [It is] a responsibility too 
gested that the committees be appointed by ballot as in the Senate. ${ }^{46}$ A little later Mr. Springer moved that the committees be appointed by the House, that the minority be represented in proportion to its numbers, and that the appointment of the minority members should be under the control of the minority. ${ }^{47}$ The effect of this motion would have been to give the majority appointments and the fixing of the proportions on the committees to a majority caucus, and the minority places to a minority caucus. The last-mentioned propositions were drawn out by the decidedly partisan composition of Mr. Keifer's committees. In favor of the Senate method it has been urged that it brings the ablest men to the front, and that the committees are therefore composed of the men best fitted for them. ${ }^{48}$ It does not appear, however, that the present House committees are less representative or are controlled by weaker men than those of the Senate. That the House committeemen are usually suited to their task is proved by the fact that they do not hesitate to express strong disapproval of any action of the Speaker which they dislike.

Since 1882 the advance in the general conception of the Speaker's power has been shown by a growing dissatisfaction with the methods of procedure.

great to be lodged in the hands of a single individual. . . . As now exercised it is emphatically a one-man power; such power is always dangerous in conflict with republican principles of government." -House Journal, 47 Cong. I Sess., 248.

${ }^{16}$ House Journal, 47 Cong. I Sess., 320.

${ }^{47}$ House Journal, 47 Cong. I Sess., 338

- Nation, XLV, 452. 
In 1885 a resolution was again introduced and referred that the House appoint the committees. ${ }^{49}$ Mr. Reed's decided action in the Fifty-first Congress (I889-9I) called attention indirectly to the appointment of committees. In I89I-93, therefore, after a political upheaval, it was suggested that the House itself elect its standing committees. Such an amendment was brought in by the People's party with the additional clause that committees should elect their own chairmen. ${ }^{50}$ Motions, however, taking from the Speaker the power of appointing the committees have never been supported by more than a very small minority. In the first place the election of the committees by the whole body of Representatives has been recognized to be an impossibility: log-rolling could not be prevented, great loss of time would be inevitable, and deadlocks frequent. In the second place, if this high privilege is to be exercised by any one person, the most proper person is the elective presiding officer and most dignified official of the House. The Senate system has become practically one of appointment by small committees of both parties, a system for which the House has no preference. In the. third place, when the first Speaker was chosen there was no suspicion of the power which this officer was to attain; it was not then expected that the privilege would be turned to political uses; no one

\section{House Journal, 49 Cong. I Sess., 8r.}

${ }^{B 0}$ Since the committees were already appointed, and since the rules of one Congress do not apply to the next, the amendment, if adopted, would have been worthless. 
then dreamed of the importance which the committees were to acquire, and which at present makes their appointment such a powerful political weapon.

There has been at least one attempt on the part of the House to restrain the Speaker from political

139. Attempts to restrain the Speaker by rule. aims in the appointment of the committees. April 8, 1836 , a resolution was introduced "That it be a standing rule of this House that in the appointment of all committees, standing or select, by the Speaker, it shall be his duty to appoint the majority, at least, of the members thereof without respect to party, of the individuals in his judgment most competent and disposed to perform the duties prescribed to said committees, respectively, and promote the objects contemplated in their appointment." 51 The motion was on the face of it impracticable and useless. In the Fifty-second Congress there was an ineffectual attempt to limit and control the Speaker's choice by the following resolution: "That the Speaker of the House is hereby requested in making appointments of committees, to distribute the same among the States and Territories according to population, and to appoint at least one chairman of said committees in each State and Territory." 52 Later the resolution was again introduced, omitting the Territories and providing that each committee should elect its own chairman.

John Quincy Adams had some severe words of ${ }^{11}$ House Journal, 24 Cong. I Sess., 65.

in Cong. Record, 52 Cong. I Sess., 22. 
censure for the committee system, " the old and beaten track, the error of which consists, first, in parcelling out all the business of the House among the standing committees, secondly, in authorizing the Speaker to appoint them all and to designate the Chairmen, and, thirdly, in that domination of party spirit which rules over the House, the Speaker, and the committees-the ineradicable infirmity of human nature. It would perhaps be possible to reduce the number of the standing committees or to appoint them by lot." ${ }_{53}$

To understand the extent of the power which is placed in the hands of the Speaker, it is necessary 140. Power of to understand the great influence over the commit- legislation which in our system of govtees.-Origin. ernment falls to the congressional committees. The first duty of the House of Representatives which met in 1789 was to provide itself with methods of transacting business. In working out this problem the House exhibited the predominant characteristic of American parliamentary practice in the last part of the eighteenth century, the effort to secure equality among the members. The tendency to embody this spirit in the actual workings of Congress was hampered by no restrictions in the nature or composition of Congress itself: it was an assembly of men equal in power as well as in rights: there were no recognized leaders of the House: the Cabinet was not admitted. Under these circumstances legislation was at first brought forward by individuals and sent to special commit-

"John Quincy Adams, Memoirs, IX, 44I. 
tees for consideration and report; and the House exercised a continual supervision over such committees, restricting them, discharging them, creating new committees on the same bill, and often demanding bills of a specific kind. Committee service shifted rapidly, and chairmanships had little significance. Where all were in a sense leaders the need of leadership was not recognized. When bills were few and simple, unity and coherence of legislation were secured without any special machinery. At first the standing committees were few: before 1794 there was only the one on Elections; twenty years after the opening of Congress there were only nine.

As the business of the House increased, the number of the committees increased, until in the Fiftythird Congress there were fifty-two sar. Control of standing committees. To some one
all bills. of them every memorial, bill, proposition, or report of a department must be referred without debate. The committee, therefore, cannot be guided in its action by previous direction from the House; and no other obligation than courtesy rests upon it to hear the friends or the opponents of the bill. It usually, however, listens at least to the member by whom the measure has been introduced. Over the legislative material thus given it the committee has almost unlimited control: the custom of bringing in bills and referring them is really nothing but a form: the committees might almost as well be allowed to introduce all legislation; they may amend a bill as they please; they 
may even make it over so entirely that it is really a new bill, reflecting the views of the committee rather than the views of the originator; or they may, either by reporting a bill adversely, or by delaying to report it until late in the session, or by simply not reporting it at all, practically extinguish a bill. Most minor measures are, in fact, accepted or rejected according to the recommendation of the committees. Of course the House may instruct a committee to report a bill or to restore a bill to its original form; ${ }^{54}$ but as the majority of the House and the majority of the committees are of the same party, the former is not likely to be very active in this direction. Besides, there are few measures which excite an interest general enough to make such action possible. Such instructions are in fact no longer given in Congress. Thus legislation rests with the committees: they may initiate what they please; they may stifle any measures which have not their approval; the rule that no bill shall be discussed without being reported by a committee might almost as well read, " without being approved by a committee." To be sure, when a measure actually comes before Congress it may be much altered by amendment, and the Senate interferes remorselessly with the details of House bills.

st There has been some question of the right of the House to instruct a committee. But Colfax made the following decision : "The Chair holds that the House of Representatives has the power to instruct any committee which it is authorized to appoint. It is a judicial check upon the power of the Speaker in appointing committees."-Cong. Globe, 38 Cong. I Sess., 892. 
There are three practices, moreover, which greatly increase the power of the committees: the privacy of their proceedings, the absence of any 342. Abuse of definite responsibility, and the lack of
power possible. united, responsible opposition. These bodies discuss with closed doors: ordinarily the country knows little or nothing of their deliberations: in strict parliamentary practice, no member is permitted to allude in the House to anything that has taken place in committee. As a result of this secrecy the committees are subject to the tremendous pressure of private interests, and bills, especially tariff measures, are sometimes merely the combined concessions to eager advocates. In the second place there is no one who can be held accountable for legislation: the House finds that it must follow the committees or do nothing; the minority of the committee easily washes its hands of the matter: "Who did accomplish these results," it says, "if not the majority?" But the majority on the other hand disclaims responsibility, declaring that the bill owes its particular shape to concessions demanded by the minority. Legislation therefore necessarily must partake largely of the nature of a compromise: responsibility exists nowhere. The power of the committees is further augmented by a legislative system which makes it no man's particular interest or duty to ferret out improper schemes. Reliance upon conscientious individuals for this purpose is not satisfactory, for no individual has sufficient power to lead a successful opposition. Log-rolling, lobbying, and a gen- 
eral laxity are thus made possible by the committees. ${ }^{55}$

Much of the power of the committees, however, comes to them through the influence they wield 143. Right of in the House itself. Compared with way in the the amount of business to be put House. through, the time of the House is extremely limited. The majority of the members are usually anxious to hasten any particular bill, as each man wishes to reach the measures in which he is specially interested. The reporting committee is as eager as any one to expedite matters, for it has other bills which it wishes to bring in before its time has expired. Thus there is seldom much debate in the House except on appropriation bills. Over such discussion as may arise on minor bills, the committees have control. In the first place committeemen are always recognized on their own measures in preference to other members. The member reporting the bill for the committee, usually the chairman, is allowed one hour. He does not use the whole of the time himself. This is indeed the only opportunity which the friends and opponents of the measure have of making themselves heard. But while it is the golden time for the individual member, he is even now by no means free from the tyranny of the rules. He must first obtain permission to speak from the reporting member. He must then acquaint the Speaker with that

${ }^{\text {ss }}$ Professor Woodrow Wilson discusses the subject in detail in his Congressional Government. See also James Bryce, American Commonwealth, I, I50-r60. 
permission in order to make sure of recognition. Even the number of minutes he may hold the floor are scantily meted out to him by the reporting member. That potentate usually ends by moving the previous question. Amendments are then out of order, and only one hour is left before the vote is taken. Thus the individual member can do little. The committees rule the House. A few years ago a writer in the Nation stated that a well-known leader of the House said it would never do to make it possible for the body of the members to pass a bill any time they chose. ${ }^{56}$

The steady tendency in the House within the last twenty years has been to give to the committees an

144. The committees the real legislstors. ever-increasing power. As the business of the country has grown, it has been necessary to leave more and more to the preparatory stage in committees. A further tendency has been to single out a few leading committees to be special repositories of power, and to depend more upon the conference committees, which often add or take away important clauses of bills at the last moment. Even the minor committees have gained more control over their subjects, since these do not possess sufficient interest to be examined thoroughly in the House, and are, therefore, almost entirely in the control of the committees. Thus Congress no longer exercises its lawful function of law-making; that has gone to the committees, as completely as in England it has passed to the Cabinet. The House of Commons can no ${ }^{\infty}$ Nation, XL, I98, May 3, 1885. 
longer be called the government, Professor Seelye tells us: it is only the government-making power. The House of Representatives in the same way is no longer the legislative power, but it is not even the maker of the legislative power; it is but the maker of the real maker, the Speaker of the House of Representatives. 


\section{CHAPTER IX.}

POWER THROUGH RECOGNITION.

THE power which the Speaker gains through 1 the appointment of the committees is sup145. Par1ia - plemented by the right of recognition. mentary $1 a w$ In strict parliamentary law, when the and practice. possession of the floor is disputed by two or more members, he who first catches the Speaker's eye is entitled to recognition. It is obvious, however, that this rule is not sufficiently comprehensive, for if two members catch the Speaker's eye at the same time, he must choose between them. In all those assemblies where the order of speaking is not provided for by lists, ${ }^{1}$ the presiding officer has come in late years to exercise a certain discrimination. Even in the House of Commons the old rule is no longer closely followed, but the selection between rival candidates for the floor is governed rather by the importance of the claimants than by any political intention: it is the Speaker's business to know the status of every member and to govern his selection by that knowledge. Usually a new member gives way to an old, ${ }^{2}$ and an ordinary

${ }^{2}$ In most of the European parliaments it is customary for those who wish to speak to hand in their names before the meeting, and permission is granted according to the order in which it is applied for. See Dickinson, Procedure of European Parliaments.

'See 153 E. Hans, 839. 
member to the heads of the government and of the opposition. It has been thought noteworthy that Mr. Courtney, Chairman of Committees, has often recognized a private member when he has risen at the same time with a "Front Bencher." "The House of Commons sometimes decides a question of recognition by vote. "Fierce is the battle occasionally," says a writer in Chambers's Journal, " when two members of opposite parties, both eminent and both willingly listened to by the House, rise simultaneously; each is encouraged by his party not to give way; a contest of cries or shouts ensues, the result of which is a regular motion that the honorable member from so-and-so be now heard." 4 Recognition is of less importance in the House of Commons because the individual member there is much more under the control of the majority.

The House of Representatives adopted in 1789 the following rule, which has never been changed:

146. Rules and "When two or more members rise at practice of the House of Reponce the Speaker shall name the member who is first to speak." 5 The word-

ing of the rule should be carefully noresentatives. ticed; it may be interpreted as giving a discretionary power to the presiding officer. When, for instance, in the Thirty-second Congress the point of order was raised that a certain member was not entitled to the floor, not having risen at the time he addressed the Chair, it was overruled by the Speaker pro tem. (Mr.

'MacMillan'sMagazine, LXV, 476.

- Chambers's Journal, LV, 580-583, 1878.

- Appendix D, Rule XIV, 2. 
Stuart) on the ground that " the rules confer authority upon the Speaker to name the member who is entitled to the floor." 6 Mr. Randall said in I880, "The right of recognition is with the Chair under the rules and under the practice." " But the rule was probably intended to mean exactly what the rule of the House of Commons expresses. Jefferson says, "The Speaker determines who was first up and calls him by name." 8 Thus the rule evidently implied that "when two or more members rise at once," and the Speaker names " the member who is first to speak," he is to name the one who in his judgment has risen first, or if that cannot be decided, he is to choose the one most entitled to the floor according to the usage of the House. But the practice has gradually grown up of the Speaker's using this ordinary parliamentary duty for political purposes, and recognizing only such persons as he pleases. Again and again when a man rises the Speaker asks, "For what purpose?" and then decides whether he is " recognized." It is a practice not confined to the House of Representatives: it has grown up also in the State legislatures. The extent of the custom is shown by the story told of a lieutenant-governor of a Western State when presiding over the Senate: he turned to the doorkeeper and said, "Go out and find Senator Gunson-he is somewhere about the Capitol-and tell him that he has been recognized and has the floor."

- House Journal, 32 Cong. 2 Sess., 405.

'Cong. Record, 46 Cong. 2 Sess., 925.

${ }^{8}$ Jefferson, Manual, §XVII. 
Recognition, even of one's friends, has long since ceased to be a haphazard affair. In most cases, when a bill is before the House for 147. Speaker's consideration, the Speaker has before
list. him a list of the men desiring to speak. So many members struggle for the floor that previous arrangement with the presiding officer has been found to be necessary. He does not feel bound by his list, however, but uses it merely as a memorandum. This practice is entirely unrecognized by the rules and has even been denied; but it is so common that in 1879 a public debate arose upon a technical question in regard to its application. It was then thought by many that the reason why they did not get a chance to speak was because the Speaker followed his list arbitrarily without using any discretion. The motion was therefore introduced April 8, 1879, that the Speaker should not consider himself absolutely controlled by the list. The subject was not brought up from any abstract interest in the question, but because the Committee of the Whole was about to take up the legislative appropriations, and many not down on the list already prepared wished an opportunity to speak on the Army bill. In that debate it was asserted by various members, old in congressional service, that the custom of the Speaker's list was thirty, forty, fifty years old. No one denied these statements, but there was decided difference of opinion as to whether the lists had been imperative on the Speaker or were merely of the nature of a suggestion. The Speaker, Mr. Randall, 
stated that when Mr. Kerr had occupied the chair he had declared the list to be only for his own convenience. $\mathrm{He}$ (Mr. Randall) presumed that was the purpose of all Speakers in having a list. Strenuous objections were thereupon raised against the practice, - that it depopulated the House, since those not down on the list had no interest to remain in the House-that it destroyed the continuity of debatethat it precluded virtually that investigation which debate is intended to effect-that it prevented the clash of mind with mind which is necessary to elucidate the truth. Mr. Randall, however, again gave an opinion from the chair. "The Chair desires to state that he himself likes the practice of keeping a list because it relieves him from a great many personal controversies between members as to who shall be first recognized by the Chair. If the Chair has a list he has something to go by, and in addition he has also an exact knowledge of who desires to speak. The Chair thinks that no real hardship has ever resulted from the practice of keeping a list." " The next day the House adopted the following report brought in by $\mathrm{Mr}$. Garfield from the committee on Rules. "In the nature of the case discretion must be lodged with the presiding officer, and no fixed and arbitrary order of recognition can be wisely provided for in advance; and the committee are of opinion that these rules should not be changed. The practice of making a list of those who desire to speak on measures before the House or Committee of the Whole is a proper one to ena' Cong. Record, 46 Cong. I Sess., 302. 
ble the presiding officer to know and remember the wishes of members. As to the order of recognition, he should not be bound to follow the list, but should be free to exercise a wise and just discretion in the'interest of full and fair debate." 10

The opportunities of the Speaker for influencing legislation through the privilege of recognition are 148. Opportunimany: they are not confined to the ties for influ- order of speaking when a bill is up for encing legisla- debate. Certain subjects are privi-
tion.

leged, as contested election cases, revenue bills, printing and accounts, conference reports. Other bills get a hearing either by unanimous consent, or under a suspension of the rules, or by having a day set for consideration. But before unanimous consent, or a suspension of the rules, or a day for consideration can be obtained, the persons desiring it must be recognized by the Speaker. A representative thus pictures for us the eager fight for recognition: "This badgering for unanimous consent must be a burden upon the Speaker. $\mathrm{He}$ is importuned by members for preference. We crowd in front of the Clerk's desk with bills, or resolutions, or propositions of which the House knows nothing, each seeking recognition." 11 During the last ten days of Congress, when the rules may be suspended at any time, the power of the Speaker is at its height. Tremendous pressure is brought to bear upon him. Day and night his room is crowded with members begging for recognition.

${ }^{10}$ Cong. Record, 46 Cong. I Sess., 340.

"Cong. Record, 46 Cong. 2 Sess., ro53. 
The struggle on the floor is severe. The time is brief. Twice on March 3, 1887, Carlisle had the minute-hand of the clock turned back. The last moments often show a scene of disorder and confusion, but the able Speaker guides this tumultuous body to the accomplishment of his own ends.

Custom, however, places important limits upon the privilege of recognition. Committees are always x49. Restric- preferred to individuals. ${ }^{12}$ There is no tions imposed rule authorizing the Speaker to recogby custom.

nize the reporter of a measure from a committee, yet it is now a well-established custom not only to let him have the floor to introduce the measure, but to allow him control of the floor during its consideration, that is, to recognize only members whom he indicates; the leading opponent of a measure is often allowed to parcel out the time given to speeches against it. It was held by $\mathrm{Mr}$. White, Speaker of the Twenty-seventh Congress, " that it was the invariable practice in conducting business in the House, after a bill had received its first and second readings, to give the floor to the member who reported it, that he might move such

12 In the Forty-ninth Congress it was held by the Speaker pro tem., and sustained on appeal, that the chairman of the committee reporting the measure under consideration was first entitled to recognition. The decision was shortly afterwards withdrawn or reversed, the Speaker pro tem. stating that it was made under a misapprehension of the facts, and the decision was then made in accordance with general parliamentary law and practice that "the member reporting the measure was entitled to prior recognition when a claimant for the floor until the bill was taken from him by an adverse vote of the House."-House Journal, 49 Cong. I Sess., 2225. 
disposition of the bill as the committee might have directed, notwithstanding another member might have previously risen and addressed the Chair." This decision was sustained on appeal. ${ }^{13}$ It is usual, when a day has been assigned a committee, for the Chair first to recognize the chairman, who may either call up a bill for consideration or yield to some other member whom he has previously requested to report the bill. ${ }^{14}$ The right of committees to preference over individuals was thus laid down by Mr. Randall in his decision of 1880 : " During the last and present sessions the Chair has laid down for itself as a rule which would govern him in all cases, that when a member claimed the floor for a motion to suspend the rules, and states that he does so under instructions from a committee, the Chair will recognize him in preference to any individual members." ${ }^{2}$ It was urged against Mr. Randall's decision that the right of an individual member to move a suspension of the rules was designed in its very origin to prevent the domination of committees over the House. Mr. Randall said that the judgment of the Speaker could be overruled, or if the House was not satisfied with the recognition which the Chair made of committeemen in preference to individual members, it could always have a remedy by voting down the motions made by those committeemen to suspend the rules, until individuals were reached. ${ }^{16}$

${ }^{18}$ House Journal, 27 Cong. 3 Sess., 211.

"Smith, Digest, 500 .

${ }^{16}$ Cong. Record, 46 Cong. 2 Sess., 925.

${ }^{26}$ Cong. Record, 46 Cong. 2 Sess., 925. 
There are many other unwritten laws of recognition: he on whose motion a matter is brought forward is entitled to the floor ${ }^{17}$ so, too, at every new stage of a bill or proposition, the Speaker should recognize the person who has had charge of it, if he wishes recognition; ${ }^{18}$ a member must always be recognized to present a matter of privilege or a question of order; during a debate the Speaker is supposed to give the floor alternately to members of each party; ${ }^{19}$ those, moreover, who have peculiar interest in or special information on certain questions are usually considered entitled to recognition. Sometimes, however, the very letter of the rule is used to evade the restrictions imposed by parliamentary law. Thus in $1840 \mathrm{Mr}$. Davis, of Indiana, moved the reconsideration of a vote. The motion being carried, Mr. Davis and Mr. Graves, of Kentucky, rose at the same time to address the Speaker. This officer announced the gentleman from Kentucky as entitled to the floor, and entertained a proposition from him differing from the one read by Mr. Davis. The question of order was raised, "That the gentleman from Indiana was entitled to the floor for the purpose of introducing the proposition which he had announced he would introduce if the motion to reconsider was carried." The Speaker decided against the point, and stated that he had recognized Mr. Graves as entitled to

"See House Journal, 30 Cong. 2 Sess., 247.

wee House Journal. 49 Cong. I Sess., 2225-7.

* By a standing rule this is necessary in the case of a subject intro. duced by a suspension of the rules.-Appendix D, Rule XXVIII, 3. 
the floor because that gentleman had first caught his eye. On an appeal to the House the decision of the Chair was sustained, but only by a narrow majority. ${ }^{20}$

Again, Speakers usually allow members to yield the floor to particular persons, but in the Fiftyfirst Congress Mr. Payson, Speaker pro tem., made without objection a different ruling. $\mathrm{Mr}$. Denny, of Nebraska, yielded the floor to Mr. Anderson, of Kansas. The Speaker pro tem. immediately announced that the gentleman from Missouri (Mr. Bland) was recognized. Mr. Payson upheld his decision by saying that the gentleman from $\mathrm{Ne}$ braska could not yield the floor. "The right to the floor is a personal right, to be exercised by the member occupying it. When he yields the floor, except for a question, he yields it for all purposes. This has been repeatedly decided by the Speaker of the House." ${ }^{21}$ But in practice objection is seldom raised to such a transfer of time once allotted. There are many instances when the presiding officer has neglected courtesy, if not parliamentary practice, in his awards of the floor. One of the earliest preliminaries of the formation of the Republican party was a conference in 1854 of some lifelong Democrats-Grow, Hamlin, Banks, Fenton, and others - with men whom they had always opposed, to consider the best means of obtaining for Thomas $\mathrm{H}$. Benton a full hearing on the question of the repeal of the Missouri Compromise. As

${ }^{20}$ House Journal, 26 Cong. I Sess., 246-247.

${ }^{21}$ Cong. Record, 51 Cong. I Sess., 879. 
Benton had been senator of the United States for thirty years, it seemed most fitting that he should be allowed more than the regular hour for his speech, but it was feared that the Speaker would prevent an extension of his time. When the hour expired Mr. Wentworth was recognized, and moved that Benton should be allowed to take the hour to which he, Wentworth, was entitled. The Speaker refused to allow it; whereupon $\mathrm{Mr}$. Wentworth by a clever stratagem moved an amendment, and thus opened anew the right to discussion, and Benton obtained a second chance. ${ }^{2}$

Speakers have long since gone beyond the point of declining to recognize a member in order that he 150. Absolute may take another member's time; all control of re- Speakers regularly claim the absolute

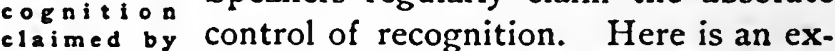
Speakers. ample of a ruling by Mr. Crisp:

"Mr. Lapham. 'I desire the gentleman to withdraw the motion [to adjourn] so that I may introduce a bill.' The Speaker. 'But, of course, if the gentleman from Mississippi withdraws the motion the Chair will have charge of recognitions." "2s

The motion was withdrawn, but Mr. Lapham was not given the floor. In the Thirty-second Congress Mr. Schermerhorn having been recognized by the Chair, Mr. Henn made the point of order that he was not entitled to the floor, as he had not risen from his seat at the time he addressed the Chair. The Speaker pro tem. overruled the point of order on

22 Wentworth, Congressional Reminiscences, 5 I-4.

"2ong. Record, 52 Cong. I Sess., 733. 
the ground that the rules confer authority upon the presiding officer to name the member who is entitled to the floor. There was an appeal taken from this decision, but the appeal was laid on the table. ${ }^{24}$ In the Forty-seventh Congress Keifer once refused to allow Randall to keep control of his time, but he concluded his ruling by saying: "The Chair does not say, however, that the gentleman from Pennsylvania will not be recognized again." 2

Formerly appeals were taken from the Speaker's decision on the right to the floor as on all other decisions. ${ }^{26}$ In 1841 the right of appeal was distinctly admitted by Speaker White: Mr. Barton, of Virginia, thinking he had been treated unjustly by White, gave notice in abusive language that he should at the proper time move an amendment to the twenty-fourth rule, to the effect that the right of recognition be with the House and not with the Speaker; whereupon White at once replied that the right of recognition was then with the House, that the Speaker merely decided conflicting claims to the floor in the first instance, but that if he transcended justice, appeal might any time be taken from his decision. "27 "The Chair is willing to obey the House in every respect," ${ }^{28}$ said Mr.

${ }^{24}$ House Journal, 32 Cong. 2 Sess., 405.

${ }^{2 s}$ Cong. Record, 47 Cong. I Sess., 4308.

${ }^{26}$ House Journal, 22 Cong. 2 Sess, 44I ; 26 Cong. I Jess., 521 (decided against the Speaker); 27 Cong. 3 Sess., 211 ; 30 Cong. 2 Sess., 247; 32 Cong. 2 Sess., 405; 34 Cong. 3 Sess., 679; 36 Cong. I Sess., 696 ; 36 Cong. 2 Sess., 440 ; 40 Cong. 3 Sess., 406. ${ }^{27}$ Cong. Globe, 27 Cong. 2 Sess., 49.

28 Cong. Record, 46 Cong. 2 Sess., 925. 
Speaker Randall in the course of a debate on the subject. But the declaration loses something of its high sound when we remember that to obey the House means only to obey the majority, and as the majority is always of the Speaker's party it will usually support him. Any effective opposition would come naturally from the leaders of the House, the chairmen of the important committees, but their obligation to the Speaker prevents them from opposing him. And the minority, however vehemently it cries out against the usurpation of authority by any officer, is always ready to use the same power when it is in the majority. In recent practice appeals from the Speaker's recognition were seldom made before the Fifty-first Congress; between 1891 and 1893 there were frequent attempts, but the relations between that Congress and its presiding officer were exceptional; such attempts were always unsuccessful, as $\mathrm{Mr}$. Reed ruled that an appeal could not be taken from a decision of the Chair on recognition. ${ }^{29}$

The power of recognition is generally used in conjunction with the chairmen of the committees.

151. Increasing tendency to use recognition ar. bitrarily.

In the debate on the rules in the Fiftyfirst Congress, Mr. Hooker gave the following account of his first attempts to gain the floor of the House. "When I first came to Congress, I . . . said nothing for a month or two, but finally a measure came up under the control of Mr. Randall. . . . Some one said to him: 'Here is a new member from Mis-

${ }^{20}$ House Journal, 51 Cong. I Sess., 177. 
sissippi and he would like to have fifteen minutes or more.' Mr. Randall scanned me over . . . and he said, " $\mathrm{He}$ is a new member and there is no telling what he will say and he had better not speak." "' 30

This is an illustration of the control exercised by a powerful chairman of a committee over his party friends; of course such a decision needs the confirmation of the Speaker. It is a favorite theory of members of Congress that this officer has no right to use his prerogative against the will of the majority. In practice he recognizes no such limitation: it is the most irresponsible of all powers, and the tendency to use it arbitrarily has been steadily increasing.

From shunting off a member of one's party because he may say something rash, it is a short step to refusing recognition to any one who has a proposition to make which is unacceptable to the Chair. Between the Speaker and the men who wish recognition there is often an open battle of tactics. Thus Mr. Julian says that he finally got the floor in 1849 to deliver his homestead speech, through the friendly assistance of Mr. Johnson, " in opposition to the earnest wish and determined purpose of Speaker Cobb." 302 Members complained that it was diffcult to get the floor while Blaine was in the chair unless the measure to be introduced had his favor, and that he sometimes demanded that legislative matter should be amended before he would allow it

${ }^{30}$ Cong. Record, 5 I Cong. I Sess., 1242.

30. Julian, Political Recollections, ro4. 
to be offered. ${ }^{31}$ Mr. Carlisle made a decided advance even on this arbitrary use of the privilege. ${ }^{20}$ Previous Speakers had thought it a power which might be used for carrying out the purposes of the party. Mr. Carlisle laid down the principle that it should be used in accordance with the Speaker's individual judgment. An interesting example of the extent to which he carried the power of recognition may be found in the history of the Blair Educational bill. This measure was pending in Congress during the whole of Mr. Carlisle's long administration; it passed the Senate three times, but was never even voted upon by the House because Mr. Carlisle would never recognize any member to move to take it up for consideration, or to fix a day for its consideration. Among many bills thus checked by Mr. Carlisle one of the most important was a proposition to repeal the internal tax on tobacco, which was introduced into several successive Congresses, yet was never voted upon in the House as a separate measure. In 1885 it would have been possible to pass it by a combination of Republicans and a part of the Democratic majority, if it could have reached a vote. Certain correspondence upon it is so significant that it should be noted in full. February 5,1887 , the following letter was sent to $\mathrm{Mr}$. Carlisle by three prominent Democrats, George D. Wise, John S. Henderson, and Samuel J. Randall:

"At the instance of many Democratic members of the House, we appeal to you most earnestly to

$$
\begin{aligned}
& \text { "See above, } \$ 60 \text {. } \\
& { }^{32} \text { See above, } \$ 68 \text {. }
\end{aligned}
$$


recognize, on Monday next, some Democrat who will move to suspend the rules for the purpose of giving the House an opportunity of considering the question of the total repeal of the internal-revenue taxes on tobacco.

"Many Republican members, we have reason to believe, are anxious to make such a motion. We believe the country is ready for the repeal of these taxes, and that a large majority of the House will so vote when an opportunity occurs.

"For a Republican to make the motion would give the Republican party all the credit accruing therefrom, and would almost certainly cause the loss to the Democracy of not less than two Southern States at the general election in the year 1888 . This is an isolated proposition, and we believe will command more votes than any other measure pending before the House looking towards a reduction in taxation; and favorable action on this proposition will not interfere with other efforts that are being made to reduce the burden of the people." \$2a

To this Mr. Carlisle two days later sent the following answer, which is a monumental document in the history of the Speakership:

"Your favor of the 5 th instant, requesting me to recognize some Democrat 'who will move to suspend the rules for the purpose of giving the House an opportunity of considering the question of the total repeal of the internal-revenue tax on tobacco,' was duly received and has been carefully consid${ }^{32 a}$ Cong. Record, 52 Cong. I Sess., 855. 
ered. A week ago, in compliance with the request made by you and other gentlemen, I consulted fully with the Democratic members of the Committee on Ways and Means for the purpose of endeavoring to formulate some measure for the reduction of taxation which would meet with the approval of our political friends, and enable us to accomplish something practical in that direction during the present session of Congress. The bill which you then submitted for their consideration proposed legislation upon both branches of our revenue laws, and on

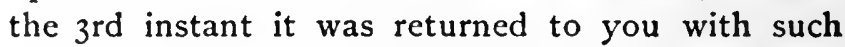
modifications and changes as were necessary in order to make it acceptable to the gentlemen to whom it had been submitted.

"In order, however, that our efforts to secure reduction of taxation might not fail on account of our inability to agree upon a measure in advance, we at the same time submitted certain alternative propositions, some one or more of which we hoped might be acceptable to you. Among other things we proposed to submit the entire subject to a caucus of our political friends with the understanding that all parties would abide by the result of its action, and in case that course was not satisfactory to you we informed you that we would at any time, upon a reasonable notice, support a motion to go into Committee of the Whole on the state of the Union for the purposes of considering House bill 9702, introduced by Mr. Randall at the last session. That bill relates to internal-revenue tax on manufactured tobacco, snuff, and cigars. 
We have received no response to that communication, and I consider that it would not be proper, under the circumstances, for me to agree to a course of action which would present for the consideration of the House a simple proposition for the repeal of the internal-revenue tax on tobacco, snuff, and cigars, to the exclusion of all other measures for the reduction of taxation.

"Sincerely hoping that some plan may yet be devised which will enable the House to consider the whole subject of revenue reduction,

$$
\begin{aligned}
& \text { " I am, very truly yours, } \\
& \text { "J. G. Carlisle.." } 33
\end{aligned}
$$

In the political campaign in North Carolina and Virginia, Democratic representatives excused themselves for not repealing the internal tax on tobacco on the ground that the Speaker of the Forty-ninth and Fiftieth Congresses, under the rules of the House, would not allow the consideration of a bill for that purpose. Many other bills, as that for the relief of disabled and dependent Union veterans, were refused consideration by $\mathrm{Mr}$. Carlisle. One of the most interesting instances in his administration is given as follows in a discussion of "The Speaker as Premier." "At the adjournment of Congress in 1887 , a member from Nebraska, who had a bill for a public building in his district, and who could not obtain the Speaker's recognition, walked for two hours up and down in front of the desk, entreating, cajoling, and ejaculating, and in

${ }^{23}$ Cong. Record, 52 Cong. I Sess., 855. 
the end tore his bill into fragments, and deposited them as a protest at the Speaker's feet." 34

Mr. Carlisle's successor, Mr. Reed, did not retrace the steps thus taken. "It is well known," says Mr. Fitch, "that the Tariff bill which carries the name of Mr. McKinley would have been altered in many of its schedules if Republicans who desired changes could have had recognition. . . " 35

Although the discrimination of the Speaker in regard to recognition has been a subject of com152. $S$ ug ges. plaint from the beginning of Congress, tions for limit- and has called forth from neglected ing the Speak- members much abuse of individual recognition. officers, yet there have been few definite proposais for a limitation of this power. In I 847 there was a whimsical motion that members " speak in an order to be decided by lot." 36 In I879 Mr. Conger again proposed "that all the names which may be placed upon any list be written separately on lists or cards and placed in a box, and when the time comes to speak one of these names be drawn from that box. In that way all would have an equal chance-the chance of lot-to obtain the floor." 37 Speakers themselves have felt the great difficulty attending the performance of this duty. On this same occasion Mr. Randall, while himself in the chair, made the following sug-

34 Albert Bushnell Hart, Practical Essays on American Government, 14 .

${ }^{36}$ North American Review, CLI, 524.

${ }^{36}$ House Journal, 30 Cong. I Sess., 157.

"Cong. Record, 46 Cong. I Sess., 302. 
gestion. "The Chair has given a great deal of reflection to this subject, and has often thought it would perhaps be well to adopt a suggestion which has been made to him. It is that members be recognized by States, and then the delegation from each State, or the Chair, could select the member from the State, so that every State might have an opportunity to be heard in the debate. But," he adds, " the subject is environed with many difficulties. It is one of the unpleasant features of the duties of the Chair to choose who shall be recognized as entitled to speak." $\$ 8$ Mr. Keifer said in his closing speech, March 3, I883: "The rules of this House which leave to the Speaker the onerous duty and delicate task of recognizing individuals to present their matters on legislation render the office in this respect an exceedingly unpleasant one. No member should have the legislation he desires dependent upon the individual recognition of the Speaker, and no Speaker should be compelled to decide between members having matters of possibly equal importance, or of equal right to his recognition. I suggest here that the time will soon come when another mode will have to be adopted which will relieve both the Speaker and the individual members from this exceedingly embarrassing, if not dangerous power." 39

The action of Mr. Reed in the Fifty-first Congress opened the eyes of many to the enormous power possessed by the Speaker and called forth attempts

20 Cong. Record, 46 Cong. I Sess., 302.

* Cong. Record, 47 Cong. 2 Sess., 3776. 
to limit that power in various directions. Among other things it was proposed that "motions to suspend the rules shall be made without naming the bills thereafter to be considered, which shall be determined by a majority of the members present, in the ascertainment of which no dilatory motion shall be allowed." 40 Thus would be taken away from the presiding officer to a great extent the control of legislation which he now exercises through the right of granting recognition to members who desire to move the suspension of the rules. But all attempts to limit the Speaker's power of recognition have been as yet unsuccessful.

Much may be said in favor of the present practice as to recognition. If every one spoke who desired, 153. criticism little business could be accomplished; of the power of inexperience and incapacity must be recognition.

kept in subordination. The custom of allowing the presiding officer control of recognition was probably originally acquiesced in because it was at first used only to prevent " speeches to buncombe," and to extinguish wearisome speakers with impossible bills to whom a large majority of the House manifested no inclination to listen. We must remember, too, that whenever the House

${ }^{10}$ Cong. Record, 52 Cong. I Sess., 888. In the debate on the rules in the Fifty-third Congress, the Speaker's right of recognition was again attacked, and it was asserted that this right was assumed hy the rule which prescribed that a member rise, "and, on being recognized," address the House. (Appendix D, Rule XIV, I.) It was therefore proposed that this rule be amended by inserting, "and shall be recognized, if in order, by the Speaker."-Cong. Record, 53 Cong. I Sess., 1043. See also II 145-II47. 
really wants to hear a particular voice it usually has its way; and filibustering may be much reduced by persistently declining to see members who are likely to bring in dilatory motions.

On the other hand the practice makes possible the neutralizing of members whom the Speaker dislikes: they may be put on committees which have no business to transact, and cases are not wanting where members have sat through two years of service without ever being permitted to " catch the Speaker's eye." Such misuse of power permits the Speaker practically to take away the representation of a district. So far as the refusal of this officer to recognize members of his own party goes, it is usually because a caucus of the party has disapproved the measures they wish to bring forward, or has decided others to be more urgent. The subject of recognition is one of the most difficult to adjust in the whole legislative system. ${ }^{41}$

${ }^{41}$ See below, § 67 . 


\section{CHAPTER $\mathbf{X}$.}

POWER AS A POLITICAL LEADER.

\section{THE Speaker of the House of Representatives 1 is the acknowledged leader of his party in} 154. The Speak- the House: if the leadership is diser the chief of puted before his election, the caucus his party.

nomination settles the question, or if, as in the case of Keifer, he prove incapable, he is speedily shelved. There never was a time when this officer was chosen for his dignity and parliamentary ability alone: he has always been a politician placed in the Speakership because that is a political office from which he can greatly advance the interests of his party. His relation to his followers has changed, however, since the first Congresses : in those early years he was always slightly subordinate or secondary to the leaders; now the leaders of the House are subordinate to the Speaker. As yet the Speakership is not sought by men who have already held high executive positions, or by members of the Senate. As its importance becomes more openly recognized the office will be more desired. It is a most significant fact that the one instance we have of a man's leaving a so-called higher branch of government for the purpose of becoming Speaker, is the desertion of the Senate by Henry Clay, the man in all our his- 
tory who saw most clearly the possibilities of the Speakership and illustrated its shining opportunities.

The career of Speakers after leaving the chair shows their position in their party: ${ }^{1}$ eleven of them have gone to the Senate, Polk became President, Colfax Vice-President; three, Clay, Bell, and Blaine, were unsuccessful candidates for the Presidency; five were later given Cabinet places, four-were sent on foreign missions, one became a judge of the Supreme Court, four Governors of their States, and others held less prominent positions. Ex-Speaker Howell Cobb in I86I presided over the Southern Congress. $^{2}$ We have three instances of Speakers resigning to take upon themselves other political duties. Clay was sent to Ghent in 1813 as one of the commissioners to negotiate peace with England. $^{3}$ Stevenson resigned in 1834 while his nomination as minister to England was pending in the Senate; ${ }^{4}$ and Colfax was made Vice-President in 1869. In the last case, Mr. Colfax was obliged to resign only on the morning of the last day of the session. ${ }^{5}$ We have one instance, however, of a Speaker steadily refusing other political honors,

${ }^{1}$ Sir Robert Peel said that Mr. Sutton refused a place in the government for fear that he should run the risk of lowering the Speakership after his long service in it.-Hansard, Parliamentary History, XXVI, 65-66.

${ }^{2}$ Schouler, United States, V, 490.

- Annals of Congress, 13 Cong. I Sess., I057.

'Debates of Congress, 23 Cong. 2 Sess., 420, 42I. He did not receive the appointment until two years later.-See above, $\S 48$.

- Cong. Globe, 40 Cong. 3 Sess., 1813, 1867-1868. 
preferring the great practical power of the Speakership: Clay, we are told, refused a mission to Russia, a seat in Madison's Cabinet, and also a seat in Monroe's Cabinet. " How," says Brownlow, writing in I843, " could he conscientiously quit a post where he wielded an influence more potent than the President's, while such momentous questions remained open?" 6

There is at present, moreover, a tendency for the Speaker to become even more than a great legisla155. Tendency to personal power. tive leader carrying out the wishes of a party. In recent years he claims more and more the position of a Premier. The idea had prevailed with very few exceptions that his political influence should be used in accordance with the will of the majority: with all his power he was still to be no more than the servant of the House. The Nation said, in 1881 , "The Speaker should never forget that it is his duty not to do legislative business for the House, or even without the House, but to guide the House in doing their business according to the true sense of the majority." " Mr. Randall said at the opening of the second session of the Forty-fourth Congress: "In the exercise of the parliamentary powers of the chair, it will be my duty and my pleasure to give true expression in the appointment of the committees to the opinions and wishes of the House upon every question presented, believing myself, as I really am, no more than the voice of the House

- Brownlow, Life of Clay, 290.

'Nation, XXXIII, 447. 
itself." 8 Little as we can depend on the perfunctory sentiments of these occasions,. Randall was probably to a great extent sincere in this expression. The expression of the sentiment, if not sincere, is at any rate significant, for his successors made no attempt to keep up even a fiction of a Speaker as "the voice of the House." The idea which Carlisle, Reed, and Crisp have sought to establish is that of a Speaker with a legislative policy of his own, using every possible means to impose that policy on majority as well as minority.

Of the many opportunities as yet unconsidered through which the Speaker may use his leadership, 156. Chairman chief in importance is that gained by of the commit- his position as chairman of the comree on Rules. mittee on Rules. This committee consists of three members of the majority and two of the minority, or, as Reed put it, of "the Speaker and two assistants," 9 for the minority members are not consulted on questions of state. The Speaker has in reality a casting-vote on what his own power shall be, as well as upon decisions which have a controlling influence over the proceedings of the House. One might say that his official consequence, patronage, and authority make him the most influential man on that committee; but while these enhance his power as chairman of the committee on Rules, they do not constitute it. $\mathrm{He}$ is the most influential man on that committee not because of his official position as Speaker, but for the

- Cong. Record, 44 Cong. 2 Sess., 6.

- Cong. Record, 53 Cong. I Sess., ro33. 
same reason which made him Speaker,-because he is the actual leader of the House. And although he gets his opportunities as leader through his powers as Speaker, he exercises them because the House accepts his political leadership. This officer was not formerly a member of the committee on Rules, but in 1860 , when the usual order was introduced for the appointment of the committee, there was added to it the clause, " consisting of the Speaker and four members." $10 \mathrm{He}$ used occasionally to feel some embarrassment in making this appointment. Thus in 1860 , when Mr. Pennington announced the committee on Rules, he added: "The resolution itself named the Speaker as one of the members of the Committee." "11 And Mr. Colfax also felt called upon to state that "The Chair . . in appointing himself . . . does so by order of the House.

The position is now, however, accepted as a part of the Speakership, and is, especially since the control of the committee on Rules has been so largely increased, one of the greatest aids to the new Speaker-Premier. Up to 1889 there had never been a recognized person or committee in Congress to decide upon the order in which bills reported from the committees should be taken up. The theory is always that bills shall be put upon the House calendar and then considered in their turn, but important bills may stand so far down the list that to reach

${ }^{10}$ Cang. Globe, 36 Cong. I Sess., 655.

- Cong. Globe, 36 Cong. I Sess., 661.

${ }^{12}$ Cong. Globe, 40 Cong. I Sess., 25. 
measures only in the regular order would mean that much needed legislation would remain unaccomplished. It is clear that a power of selection must be placed somewhere. Since the repugnance of the House to any directory body, to " the rule of the few," long prevented the matter from being definitely settled, the presiding officer took upon himself, in a large degree, the duty of selection. $\mathrm{He}$ accomplished it first through his privilege of recognition. But this not proving sufficient, the practice grew up of allowing the committee on Rules a certain control over the arrangement of business. In the Fifty-first Congress the custom, until then entirely unofficial, was formally recognized. ${ }^{13}$ It became the practice of the committee on Rules to bring in reports that a certain measure should be introduced, or to fix a time at which a vote should be taken on a pending measure. As this committee had the right of way in the House, and could always get the previous question ordered upon the adoption of its reports, it could undoubtedly accomplish much that it wished. The Fifty-second Congress, however, by allowing it further privileges, made a decided advance towards the consolidation

\footnotetext{
${ }^{13}$ As early as 1856 , however, the committee on Rules was given "leave to report at any time such amendment and revision of the same as they shall think proper; and such report when made, shall be considered by the House as a special order." There was considerable objection to the new clause. The Chair decided that it was not in order on the ground that so far as it gave the committee leave to report at any time it conflicted with the rules of the House. But the resolution was finally agreed to.-Cong. Globe, 34 Cong. I Sess., $52 \mathrm{I}$.
} 
of power in the hands of a few leaders with the Speaker at their head. The following new rule was adopted: "It shall always be in order to call up for consideration a report from the committee on Rules, and pending the consideration the Speaker may entertain one motion that the House adjourn; but after the result is announced he shall not entertain any other dilatory motion until the said report shall have been fully disposed of." 14 .The power of the committee was still further increased by the regulations of the Fifty-third Congress (I 893-1 895), which allowed it to hold a session at any time. ${ }^{15}$ Furthermore, the Fifty-third Congress abandoned the longstanding provision that no rule or standing order should be changed without one day's notice. This omission enables the committee on Rules to submit a report on the order of business without previous notice, and without the reference to it of any resolution on the subject.

By these provisions the committee on Rules has now great power. It practically decides what shall be considered, how long debates shall last, and when the votes shall be taken. The calendars are far too crowded for any measures to come forward not favored by the powerful body of three persons. At present, therefore, the effort of friends of an important measure is to get the committee "to report a rule," that is, to permit the House to reach a vote on a measure. Of course, the House retains its usual power to demand a report, and it is not

14 Appendix D, Rule XI, 57.

${ }^{26}$ Appendix D, Rule XI, 58. 
bound to accept reports after they have been made : twice in the Fifty-third Congress the committee on Rules was beaten in the House, but that the victory was usually with the committee is well known by the members of that Congress. Several times the committee refused to "report a rule," unless the request was backed by a caucus resolution or by the signatures of a majority of the dominant party; but there is always a tendency to follow the leaders, and not to lay down the law for them. What business shall be considered in the House of Representatives, and what measures shall be decided, depend largely, then, upon the committee on Rules. The fate of a bill is often affected by a change in its hour of consideration or by the time when debate must close. This controlling board can, moreover, transfer bills from the Committee of the Whole to the consideration of the House; thus bills which could not pass in the former body, where debate is freer and difficult to restrain, may pass in the House. The power of the committee on Rules to report resolutions which have not been referred to it is not unique. The committee on Appropriations, for instance, brings in bills based upon nothing but the estimates. Still, that the committees shall originate legislation is not included in the idea of the committee system : it is against ordinary parliamentary practice, and the right thus allowed the committee on Rules marks it as the recognized political leader of the House.

The Speaker's influence through the committee 
on Rules does not begin or end in the committeeroom. He appoints the committee; it meets only when he calls it, and he may refuse to call a meeting which might appoint a day for the consideration of a bill to which he is opposed; he can thus defeat measures which he does not care to oppose openly. Mr. Randall once made evident from the chair his idea of the connection of Speaker and committee : a member objected to the reference of a certain matter to the committee on Rules, ". . . But they never report." "The Chair thinks they will," said the Speaker; "they will report if he has any influence with the committee." 16 Evidences of a similar guiding hand in the reports of this body have since been visible. Mr. Crisp left the chair August 29, I893, to debate on the rules: "The methods and practices of the Fifty-second Congress," said he, "have been assailed and ridiculed, and those of the Fifty-first Congress have been applauded, upon the floor of this House, and I have had no opportunity to say anything in reply." 17

Nevertheless the establishment of so small a ruling committee led to the customary xy7. Stcering references to "Russia," "the auto-
committee. crat," " three men ruling the House of Representatives." In the Fifty-second Congress,

${ }^{16}$ Cong. Record, 46 Cong. I Sess., 304.

${ }^{17}$ Cong. Record, 53 Cong. I Sess., I034-5. Mr. Reed, following, spoke of the unusualness of a Speaker leaving the chair, and said that it had been questioned whether he ought to do so.-Cong. Record, 53 Cong. I Sess., 1035. 
moreover, the Democratic members were all from the Southern States, Georgia, Tennessee, and Mississippi, and there was some complaint that the three men with the most power over the legislation of the United States should come from the same section of the country. ${ }^{18}$ Various propositions were accordingly introduced both to enlarge this committee and to make it more "representative." 19 It was proposed that it should consist of seven, of nine, and again of fifteen members; ${ }^{20}$ it was suggested that it should include all the chairmen of the standing committees, about fifty in number; again, that it should be composed of one member from each State or Territory, to be nominated by that State or Territory. Since the chairmen of the standing committees have already much power, there seems some aptness in the suggestion to combine them; but it is manifestly impossible to have a board on the arrangement of business consisting of forty or fifty members. Another proposition was for a committee on the order of business to consist of fifteen members, ten to be Democrats, five Republicans, and the Speaker to be chairman, but the members to be designated by the Republi-

${ }^{18}$ Cong. Record, 52 Cong. 2 Sess., 670.

${ }^{10}$ In the Fiftieth Congress a resolution was offered to increase the committee on Rules, so that it should consist of the Speaker and six persons.-Cong. Record, 50 Cong. I Sess., 124.

${ }^{20}$ Cong. Record, 52 Cong. I Sess., 73. In the Fifty-third Congress, the committee on Rules was again attacked, and amendments proposed to increase its numbers. - See Cong. Record, 53 Cong. I Sess., 1042, $1077-8,1084,1085$. 
can and the Democratic caucus. ${ }^{21}$ None of these amendments, however, received any considerable support.

The Fifty-first Congress undoubtedly accomplished a large amount of important business, and it was able to do so through the increased power of the committee on Rules. Of course, the efficiency of Congress ought not to be increased at the expense of its freedom, and there have been undoubted cases of arbitrary action on the part of this committee in the Fifty-first, the Fifty-second, and the Fifty-third Congress, - of its bringing in reports, precipitating the previous question, and thus pushing through its measures without allowing proper consideration. The committee on Rules will occasionally abuse its power. The real question is whether abuses of power by a body representing the majority, and in the end responsible to the country, are comparable with the abuse of power by filibusters, and the loss of time by the clashing of rival committees and factions. The House of Commons does its business under the direction of the ministry, and some way must be found of concentrating both power and responsibility in the House of Representatives.

Even in the chair the Speaker does not deny 158. Opportunities of leadership in the chair.

himself the exercise of his leadership. From the chair, indeed, a presiding officer is usually expected only to explain points of order, to sustain his decisions in case of an appeal, and to give any information ${ }^{21}$ Cong. Record, 52 Cong. I Sess., 730. 
that is requested upon the business under consideration. But the Speaker of the House of Representatives does far more than this might imply. If he wishes to indicate his opinion to his followers, he may follow the logic of Mr. Polk, who said during the slavery discussion brought on by Slade in I837: "I am not permitted to give my own opinions, but they may readily be inferred by the House." 22 Although the Speaker does not regularly debate from the chair, yet he sometimes takes sufficient part in a discussion to guide it where he wishes. $^{23}$ Unless he should go so far as to merit the censure of the House, an extreme measure which it has never been necessary to take in the House of Representatives, he may speak when he chooses. ${ }^{24}$ There is no remedy if he disregards the traditions of silence. As General Butler put it, " The Speaker always has the floor." So this parliamentary general, by a meaning word or a suggestive glance, hints his commands to apt and ready followers. Here is an illustration which speaks for itself :

"Mr. Mann: 'I would like to ask the gentleman a question.'

"Speaker Reed: 'The gentleman from Ohio declines to be interrupted.'

${ }^{22}$ Cong. Globe, 25 Cong. 2 Sess., 4I.

${ }^{23}$ In 1825 , certain charges having been brought against Clay, he asked for an investigation of the House. The question was then raised whether his request, being oral, could be entered in the Journal, as it was only customary for the Speaker to speak on entering and leaving the chair. It was decided that the House might direct it to be entered in the Journal. - Cong. Debates, I8 Cong. 2 Sess., 444.

${ }^{24}$ See Hatsell, Precedents, II, 23I, 239. 
“Mr. McKinley: 'I decline to be interrupted.'

Or again :

"Speaker Randall: 'The Chair has allowed ample debate because the question related to the privileges of members. . . Does the gentleman from North Carolina insist on the demand for the previous question ?'

"Mr. Scales: 'I do not." ", 25

When Mr. Hickman's bill " to define and punish certain conspiracies" came up in July, I861, a motion was made that it should be postponed until the next day ; whereupon the Chair stated that the motion was not in order if objected to ; upon this suggestion, objection was made and the bill was passed. ${ }^{26}$ When a member requests permission for an extension of his time, the Speaker may, after a second's pause, announce that if there is no objection the gentleman will proceed; but if he wishes to stop his remarks he may by his manner show his desire, and some one of his party will make the motion that the member shall not proceed. The Speaker does not hesitate, moreover, at any time, to communicate with the members on passing business. John Quincy Adams says in his diary: "The Speaker came and spoke to me of my appeal from his decision, in which he said he wished me to persist." 27 The famous hint of Blaine has already been dis-

${ }^{25}$ Cong. Record, 46 Cong. I Sess., 303. This whole debate of April 8,1879 , is a good illustration of the way the Speaker may, by frequent interruption and interpolations, take part in a discussion of the House. 46 Cong. I Sess., 303.

${ }^{26}$ Cong. Globe, 37 Cong. I Sess., 30.

${ }^{27}$ Adams, Memoirs; X, $22 \mathrm{I}$. 
cussed. ${ }^{28}$ The presiding officer can reach members as easily by a note from the chair as by a word on the floor. Even when he is silent there are still many ways in which he can intimate his wishes to his associates. It was said of Mr. Reed, "When the time comes for a motion to be made he glances at McKinley or Dalzell, and they pop up at the beck of their master." The Speaker's power of silent indication of his wishes was once bitterly criticised by an abolition writer, a source not altogether unprejudiced: "When they found that a majority had voted the same way, and that the slave-driving Virginia Speaker was making an awful. pause before declaring the decision of the House, they rose and changed their votes. This is a common trick." ${ }^{20}$

The Speaker can perhaps control his followers better in the chair than on the floor, since his position gives him an added consequence, and enables him to inflict party punishment should they prove refractory. There is a great difference in the ability of presiding officers to so guide the House as to reach definite results, but one who holds the reins firmly may often drive the House where he pleases. Speakers often, moreover, frame the resolutions brought in by their subordinates: Mr. Reed, it is said, was very active in this respect; and we know of one instance when $\mathrm{Mr}$. Blaine framed a resolution for a committee on reconstruction, and moved around the floor of the House to gain adherents to

${ }^{28}$ See above, $\$ 63$.

29 An appeal from David L. Childs, editor of the Anti-Slavery Standard, to the Abolitionists, 13-I4. 
his resolution when it should be properly introduced. ${ }^{30}$

When Frederick A. Muhlenbergh, first Speaker of the House of Representatives, was conducted to

159. Speeches at the opening of the House. ${ }^{31}$ the chair, he made a short speech in acknowledgment of the " distinguished honor" which had been conferred upon him. ${ }^{32}$ His example has been followed by his suc-. cessors. These inaugural speeches usually contain thanks for the election, an expression of the unworthiness of the incumbent, a request for the help and support of the House, and pledges of impartiality, integrity, and assiduity. They often flatter the House, moreover, by references to its high character or the unusual importance of the duties which have fallen to its share. The early Speakers confined themselves to such expressions as these, with perhaps a statement of the Speaker's high position and the qualities he should possess: the two latter elements we find in Clay's speech of $1823^{33}$ and in Stevenson's speech of $1827 ;^{34}$ Stevenson, moreover, urged the members " to realize the just expectations" of their constituents, and to let their proceedings be characterized by a "cool and deliberate

${ }^{30}$ See above, $\$ 62$.

${ }^{31}$ The only two regular occasions when the Speaker addresses the House is upon entering and leaving the chair. The Speaker of the House of Commons makes an address also when he claims the privileges of the House and when he presents the Supply bill for the assent. of the House.-May, Parliamentary Law, 501 .

"Annals of Congress, I Cong. I Sess., 96.

${ }^{33}$ House Journal, 18 Cong. I Sess., 7-8.

* Cong. Debates, 20 Cong. I Sess., 811 . 
exertion of the talents, fortitude, and patriotism of the House."

From these early speeches we should gather no hint that the office had any other significance than to preserve order in the House. Later Speakers, from Colfax on, have seemed to consider it incumbent upon them not only to urge the House to a performance of its duty, but even to point out that duty in specific terms. ${ }^{35}$ Thus Colfax, after thanking the members in a word for their confidence and regard, and appealing to them for their support and forbearance, with none of the usual pledges of impartiality, devoted the main part of his speech to dwelling upon the grave importance of the questions they were called upon to settle, and insisting upon the care, thoughtfulness, and good feeling which should be brought to their solution..$^{36}$ At the opening of the next Congress he went further, and indicated the line of policy which should be pursued in regard to reconstruction. ${ }^{37}$ Speaker Randall grew still bolder. Members were admonished to frown down with relentless and unsparing condemnation unauthorized and unconstitutional acts of executive officers. ${ }^{38}$ In $188 \mathrm{I}$ Mr. Keifer said, "With few grounds for party strife and bitterness, . . the present is an auspicious time to

${ }^{35} \mathrm{Mr}$. Grow, in his speech of July 4, I86I, emphasized the glorious career of our government under the Constitution, and ended with an exhortation to preserve the Union. His was the longest opening speech ever made in the House.-Cong. Globe, 37 Cong. I Sess., 4.

${ }^{*}$ Cong. Globe, 38 Cong. I Sess., 7.

"Cong. Record, 39 Cong. I Sess., 5.

${ }^{29}$ Cong. Record, 44 Cong. 2 Sess., 6. 
enact laws to guard against the recurrence of dangers to our institutions and to insure tranquillity at perilous times in the future." 39 In I $883 \mathrm{Mr}$. Carlisle spoke more plainly than any one else as leader of a political party. "Sudden and radical changes in laws and regulations affecting the commercial and industrial interests of the people ought never to be made," he said, " unless imperatively demanded by some great public emergency; and in my opinion, under existing circumstances, such changes would not be favorably received by any considerable number of those who have given serious attention to the subject." 40

In 1887 he spoke at greater length: "It must be evident to every one who has taken even a partial view of public affairs that the time has now come when a revision of our revenue laws and a reduction of taxation are absolutely necessary in order to prevent a large and dangerous accumulation of money in the Treasury. Whether this ought or ought not to have been done heretofore is a question which it would be useless now to discuss. It is sufficient for us to know that the financial condition and the private business of the people alike demand the prompt consideration of these subjects and a speedy enactment of some substantial measure of relief.

"Unfortunately, gentlemen, we are menaced by dangers from opposite directions. While a policy of non-action must inevitably, sooner or later, result in a serious injury to the country, we cannot

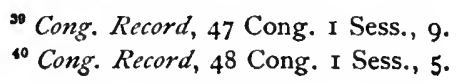


be unmindful of the fact that hasty and inconsiderate legislation upon subjects more or less affecting great financial and industrial interests might produce, temporarily at least, disturbances and embarrassments which a wise and prudent course would entirely avoid. Investments made and labor employed in the numerous and valuable industries which have grown up under our present system of taxation ought not to be rudely disturbed by sudden and radical changes in the policy to which they have adjusted themselves; but the just demands of an overtaxed people and the obvious requirements of the financial situation cannot be entirely ignored without seriously imperilling much greater and more widely extended interests than any that could possibly be injuriously affected by a more moderate and reasonable reduction of duties." ${ }^{41}$ Carlisle appreciated the innovation he was making, for he concluded his remarks thus: "Gentlemen, I know that these remarks may be considered somewhat out of the usual course, and perhaps not altogether pertinent to the occasion; but I believe you will excuse them because they relate to subjects which, as we assemble here to-day, are uppermost in the minds of all the people. Upon the correct solution of the questions which these subjects necessarily involve may depend not only the fate of political parties, but, what is far more important, the permanent welfare of the greatest and most intelligent constituency in the world." 42

"Cong. Record, 50 Cong. I Sess., 7.

"Cong. Record, 50 Cong. I Sess., 7. The minority regarded 
It seemed as if the speech of the Speaker at the opening of each Congress might come to be looked forward to as an embodiment of the policy of his party. But Mr. Reed did not follow these examples, and Judge Crisp's speech had rather the flavor of the early years of Congress. Expressing thanks for his election and the assurance of "firmness, courtesy, and absolute impartiality," he closed his brief remarks with the hope that the labors of the House might result in the " prosperity, honor, and glory of our beloved country." 43

The first official statement recognizing the Speaker's position as a party officer we find in $\mathrm{Mr}$. Blaine's speech of $187 \mathrm{I}$, where he says, "Chosen by the party representing the political majority in this House, the Speaker owes a faithful allegiance to the principles and policy of that party." $\mathrm{He}$ adds, however, "But he will fall far below the honorable requirements of his station if he fails to give the minority their full rights under the rules which he is called upon to administer." 4 In 188I Mr. Keifer said, "Where party principle is involved I will be found to be a Republican, but in all other respects I hope to be able to act free from party bias." 45 Mr. Keifer's subsequent course, however, shows that the latter clause was superfluous. Mr. Reed this speech as a " gross impropriety." "It was a speech," said the New York Tribune, "which seemed to demand an immediate reply, yet none could be made without creating a scene." -New York Tribune, Dec. 6, 1887 .

" Cong. Record, 52 Cong. I Sess., 9.

4 Cong. Globe, 46 Cong. I Sess., 6.

4s Cong. Record, 47 Cong. I Sess., 9. 
made an elaborate distinction between the political and the parliamentary duties of the Speaker. "So far as the duties are political," he said, "I sincerely hope that they may be performed with a proper sense of what is due the people of this whole country. So far as they are parliamentary, I hope with equal sincerity that they may be performed with a proper sense of what is due to both sides of this chamber." 46

The full power of the Speaker as a leader can, however, never be understood by a mere discussion 360. Retention of his political powers as such. There of a member's is one fact which has been neglected privileges.

above all in the discussion of the Speakership which is of the utmost importance, and which cannot be too strongly emphasized: it is that the Speaker of the House of Representatives is at the same time a member, and it is in a large degree through the retention of the ordinary privileges of a member that he is able to become a leader. This twofold character of the Speaker it accounts for much that might otherwise puzzle us in the history of his office. The Speaker of the House of Commons expects to give up his rights as a member for the sake of sitting in the chair: he neither votes, except when a casting-vote is required, nor takes any part in the debate ${ }^{48}$ custom

"Cong. Record, 5I Cong. I Sess., 8r.

"Three times the Speaker has performed some action, distinctly stating that he did so as a member from the State of Indiana or Maine or Pennsylvania. The Speakers were Colfax, Blaine, and Randall. See above, $\$ \S 57,62,93$.

4s "The Speaker hath no voice in the House, nor will they suffer 
guards him so strictly, indeed, that he is not even allowed to make political speeches outside Parliament. ${ }^{49}$ All three of these important rights-vote, debate, and influence out of doors-are retained by the Speaker of the House of Representatives.

Under strict parliamentary practice the Speaker does not vote except where his vote would be decisive, and does not submit propositions or participate in debate. But we have seen that without objection from the House he votes when he pleases. Speakers have always introduced petitions, bills, and resolutions through other members. In 1854 Mr. Linn Boyd even gave notice from the chair of submitting an amendment to the Homestead bill at the appropriate time: the amendment was read to the House. ${ }^{50}$ Now, since the change in the rules by which papers are deposited at the Clerk's desk instead of being presented by the members in open House, Speakers regularly present bills, petitions, and resolutions themselves, a proceeding which would be considered very improper in the House of Commons.

Whatever the restraining effect of the chair, the presiding officer may at any time leave his place and take part as a member in the debate of the

him to speak in any Bill to move or dissuade it."-Lex Parliamentaria, 270.

19 Although all bore testimony, Walpole tells us, to Mr. Speaker Sutton's impartiality in the chair, yet he lost his reëlection to the Speakership of the second reformed Parliament because he had indulged in partisan warfare outside the chair, and assisted at meetings of conservatives. - Walpole, History of England, III, 288.

${ }^{t 0}$ House Journal, 33 Cong. I Sess., 518. 
House. There has never been anything in the rules to prevent such withdrawal from the chair. In 1837, 16r. Right of however, the right was questioned, leaving the and Mr. Patton said that although he chair.

"was not aware that there was any rule of the House prohibiting the Speaker from participating in the discussions of the House, certainly not in terms, he would . . . offer an amendment expressly giving him the right, in the following words: "That the Speaker, whenever he desires to debate any question under consideration, shall be at liberty to call any member to the chair., " 51 The amendment was not passed, apparently because it was understood by most members that this might always be done without a rule. In the Twenty-eighth Congress (1844), however, when the House took up the contested election case in which the Speaker's seat was involved, the clause in Jefferson's Manual upon the subject ${ }^{52}$ appears to have been remembered and considered restrictive, for it was thought necessary to make the following order, which passed by unanimous consent: "That the Speaker of this House, whose right to a seat as a member of this House is contested, have leave to speak upon this resolution; notwithstanding the clause of the marual which restrains the Speaker from addressing the

\footnotetext{
"Annals of Cong., 25 Cong. 1 Sess., 626-627.
}

62 ". . . Though the Speaker may of right speak to matters of order, and be first heard, he is restrained from speaking on any other subject, except when the House have occasion for facts within his knowledge, then he may, with their leave, state the matter of fact (3 Grey, 38 ").-Jefferson, Manual, §XVII, 
Chair except upon questions of order." 53 And Mr. Speaker Cobb, having been charged with mutilating the Journal, asked leave from a seat on the floor to make an explanation; the Speaker pro tem., Mr. Winthrop, said that he might address the House by unanimous consent, which accordingly was granted."s No later instance has been found, however, of either Speaker or members demanding action of the House in this respect. Colfax left the chair without action of the House to move the expulsion of a member, ${ }^{55}$ and Blaine to enter into a personal controversy with General Butler. ${ }^{56}$ Later Blaine offered a resolution from the floor for a select committee to investigate the charges of bribery made against members of Congress for having received presents of stock in the Credit Mobilier. ${ }^{57}$ Recent Speakers have availed themselves more freely of the privilege of leaving the chair.

In the Committee of the Whole the Speaker has the status of a private member and may both speak 162. Incommit- and vote as he pleases. He naturally tee of the avails himself fully of this privilege. Whole.

In the House of Commons, too, such was formerly the practice; ${ }^{58}$ but lately, with the growing strength of party feeling, the Speaker has

ss House Journal, 28 Cong. I Sess., 1018.

s4 The committee decided that the changes which Cobb made in the Journal were not a mutilation, but a "proper correction" of the Journal.-Cong. Globe, 31 Cong. I Sess., 6rg.

's See above, $\$ 57$.

"See above, $\$ 62$.

${ }^{67}$ Cong. Record, 42 Cong. 3 Sess., 8.

Hatsell, Precedents, II, 243. 
abstained in great part from the exercise of this right; ${ }^{59}$ he never votes in committee, and he speaks only under exceptional circumstances. $\mathrm{He}$ always, for instance, explains any matters connected with the internal economy of the House, and sometimes, when the estimates are under consideration, refers to matters which interest his constituents; but he carefully abstains from taking part in a matter of party controversy or debate, and if at times he feels compelled to express a strong dissent from any public measure, he confines himself to the expression of his opinion, and does not enter into any argument with others who may differ from him. Mr. Fletcher Morton, while Speaker of the House of Commons in 1780 , gave his opinion as to the propriety or advisability of the presiding officer's taking part in the debate of the Committee of the Whole: he said that he knew from experience that whatever he should support as an individual member might bias his judgment in his other character, that of Speaker. ${ }^{60}$

In the House of Representatives there prevails no such punctilious adherence to the principle of absolute impartiality. If such were the case the Speaker's position in our system of government would be materially changed, for it would then be necessary to elect an entirely different man to the office. The presiding officer of the House of Representatives is not only a member of a party, but the leader of a party; and this is possible, since, as nearly all

so For precedents see May, Parliamentary Law, 347-9.

${ }^{\circ 0}$ Hansard, XXI, 259-26r. 
important subjects are discussed in the Committee of the Whole, his party knows that by putting its chief in the chair it still does not deprive itself of his leadership. The custom of going into Committee of the Whole is indeed peculiarly felicitous to the system of directorship: the Speaker is thus able to influence legislation in two ways, directly and indirectly:- during the consideration of nearly all important measures, he leads his party on the floor; and through the privilege given to him of appointing the chairman of the Committee of the Whole, at the same time that he is leading his party on the floor, the House is being guided by the man he has put into the chair, presumably one who will handle measures as he wishes. The practice, therefore, of allowing the Speaker voice and vote in the Committee of the Whole has had a very considerable influence in shaping his position in the government.

Much might be said against the propriety or expediency of allowing the Speaker other than official r63. Dangers. privileges: under the present system it is not his first aim to perform well the duties of the chair; his personal consideration is lessened by the defeat of measures which he has tried to pass in committee, as well as by his pronounced party attitude; his dignity is weakened by constant controversy; he may be required to act as a judge upon the very proceedings in which he has been taking part as a member; it seems, too, that by participating freely in debate, he must often incur the personal opposition of members, an unfor- 
tunate sentiment for a presiding officer to arouse. Clay's experience shows clearly the dangers of a Speaker's taking an active part as a member: over and over again while he was in the chair his statements from the floor were attacked and contradicted; his change of position between 1811 and 1816 in regard to rechartering the United States Bank furnished the opportunity for Randolph to use the most offensive language against the Speaker of the House of Representatives. Although Clay seemed by such encounters and attacks to lose none of his authority in the chair, it would seem almost inevitable that a lesser man would find his position weakened. But these considerations have had little weight against the strong traditional feeling in favor of a Speaker's retaining his rights as a member, and against the steady development of the Speaker into a party leader. 


\section{CHAPTER XI.}

THE SPEAKER'S PLACE IN OUR POLITICAL SYSTEM.

IVING considered the history of the Speakership, the principles which govern the Speaker's choice, the influence which individ164. Preced- uals have had upon the office, and its
ence. various parliamentary and political prerogatives, let us now summarize the present status of the Speaker and examine his exact position in the American system of government. His official place has been ranked by custom next to that of the President and Vice-President. ${ }^{1}$ When Mr. Winthrop entered upon the office in 1847 , he asked John Quincy Adams what he should do in the matter of precedence. Adams replied, "The Speaker of the House of Representatives, as representative of the people's representatives, is next to the President and Vice-President. Call upon no one else." Mr. Winthrop did call also on Chief Justice Taney, but more as a personal friend than because he thought it required by his position. Mr. Winthrop tells also of an occasion when Congress was invited to a dinner by the city of Washington:- the chief executive was not there, but Cabinet Secretaries and

'The Speaker of the House of Commons, by custom and by law, takes precedence of all other commoners.-May, Parliamentary Law, 219. Hatsell, Precedents, II, 249, 250. 
Senators were present; when, therefore, the Mayor was about to take the Speaker out to dinner, Mr. Winthrop hesitated a moment, but he was quickly reassured by hearing Senator Benton, who was a great stickler for etiquette, cry out: " Be as modest as you please, Winthrop, but don't compromise the House of Representatives." 2 The reason for this distinction is not so much the actual power of the Speaker as his peculiar duties. The President, Vice-President, and Speaker all sign bills, and Mr. Winthrop thought this the reason for their status as the first three officers of our government.

Again, until 1887 the Speaker was, after the President of the Senate, designated to succeed to the Presidency, if both President and Vice-President were incapacitated for the office. This, too, helped to settle his rank. He has sometimes been compared in dignity to the other great officers of the government: but the appointive justices of the Supreme Court do not directly represent the people; the members of the Cabinet are subordinate; the Senate represents the States. It is as the head of the popular branch of the government that the Speaker rightfully comes next in dignity to the President and Vice-President, as he is surpassed in power by the President alone.

The first act of Congress relating to the compen265. Compen- sation of the Representatives gave to sation of the its ordinary members six dollars a Speaker. day, to the Speaker twelve dollars. ${ }^{3}$

${ }^{2}$ Personal interview with Mr. Winthrop.

'House Journal, I Cong. I Sess., 6r. 
The House seems in this respect to have followed the precedent of the State legislatures, which usually paid the presiding officer twice as much as other members. However small this allowance in comparison with the splendid emolument of the Speaker of the House of Commons, or even with the present Speaker's salary, it was considered then most generous compensation, such as was due to the dignity of his position and the necessity that he should entertain his fellow members. It was felt that the duties of his office demanded a more intimate acquaintance with the members in order that he might make those appointments which belonged to the Speakership in the wisest manner. Indeed, one member objected to the bill that it simply provided means for feasting.

Although the act passed with little difficulty, the uneasiness of members continued, both with regard to the salary and to the revelry. In the debate on the salary bill of 1816,4 it was proposed that the Speaker's salary should be considerably reduced inasmuch as the dinners were no longer given; many protested against the whole dinner system; some admitted that the Speaker was put to more expense in receiving than other members and had more laborious duties in the House, and should receive additional recompense; others insisted that his duties were not so great or his services so valuable as those of committee members; Madison thought a high salary was necessary in order to induce men of talents to accept the chair; certain representatives main'Annals of Cong., $1_{4}$ Cong. I Sess., 376-9. 
tained that the honor and the dignity of the office were sufficient inducement without extraordinary compensation. But the argument which carried most weight was the Speaker's important official position : he ought, it was agreed, to be enabled to take a house in Washington and to live in a manner becoming a high officer of the state. The salary of the Speaker was therefore fixed at $\$ 16$ a day "for every day he . . . shall attend the House," that of unofficial members being $\$ 8$ a day. In 1856 this was raised to $\$ 6,000$ a year, ${ }^{5}$ and in 1866 to its present amount of $\$ 8,000 .^{6}$

Let us now, at the risk of some repetition, briefly state the Speaker's powers. In the first place, he

166. Summary

of Speaker's powers." exercises certain parliamentary duties not usually entrusted to a presiding officer in other countries: those of appointing the chairmen of Committees of the Whole, of choosing Speakers pro tem., of referring bills, and of voting on occasions that do not require a castingvote. Secondly, in the use of these and also of the ordinary parliamentary duties of the chair, custom lays little restriction upon him: he appoints as chairmen of the Committee of the Whole men

- Appendix E, Statutes at Large, XI, 48 ; chap. I23, $\$ \S$ I, 3.

- Appendix E, Statutes at Large, XIV, 323 ; chap. 296, § 17 . In I 873 the bill which raised the pay of members to $\$ 7,500$ gave to the Speaker \$ro,000 (Statutes at Large, XVII, 486 ; chap. 226), but in the following year these particulars of the bill were repealed (Statutes at Large, XVIII, 4 ; chap. 2 ).

7 For certain minor appointments vested in the Speaker, see Appendix E, Revised Statutes, $\S \S 5581,3756,4863$, 1327; Statutes at Large, XVII, 360; XIX, 52 ; XX, 290. 
who will guide debate as he desires; he appoints as temporary Speakers men upon whom he can rely to carry out his own legislative policy; decisions on questions of order he often uses as an aid in accomplishing his political aims; he gives his vote always as a member's vote, and he refers bills, as far as he is able, in such manner as will insure the passage of the measures he favors and the defeat of those he opposes. The Speaker of the House of Commons as he steps into the chair is expected to shake from him all party ties and to administer parliamentary law with absolute impartiality to friends and foes. The Speaker of the House of Representatives, on the other hand, is not only allowed, but expected, to use his position to advance party interests. It must not be supposed, however, that this implies gross partisanship on the part of our Speakers. They neither attempt to use every inch of power to be conjured out of the rules, nor guide the House entirely from party motives. Their office has on the whole been administered with justness and fairness: there exists a certain standard of what is proper from the chair, and of what is due the minority, and to this Speakers have usually adhered. But that standard has altered much in the course of a century, so that the Speaker now exercises unquestioned a large degree of control over legislation. I In the third place, the Speaker has acquired purely political powers: the appointment of the committees of the House; the important position of chairman of the committee on Rules; and the right of discrimination between 
members claiming the floor. In the fourth place, there is no longer any obligation imposed upon the Speaker by his position in the chair to refrain from influencing his followers on the floor. / Finally, the Speaker of the House of Representatives possesses at the same time the essential privileges of a member of the House of Representatives.

With such powers it is hardly strange that a member of the House said in 188I, "When this Republic goes down . . . it will not be through the ' man on horse-back' or any President, but through the man on the wool-sack in this House, under these despotic rules, who can prevent the slightest interference from individual members; who can, if he will, make and unmake laws like an emperor, hold back or give the sinews of war and the salaries of peace." 8 Every man who is elected to the office understands the vast power which he has both of serving his country and of serving his party; but he serves not as the creature of his party, he is its leader. As a leader, he at one moment decides what business shall come before the House, at the next, appoints the man who shall guide the House during its deliberation upon that business, then may himself take a responsible part in the affair-managing it, debating and voting upon it-and, finally, he decides questions of order which have arisen from this very matter. By this extraordinary combination of powers the Speaker is at the same time a moderator, a member, a party chieftain, and the most influential man in the House.

- Cong. Record, 46 Cong. 2 Sess., 1207. 
What has been the origin and the process of this remarkable development? Like many other Amer367. Causes of development.Early tradi tion. ican institutions, the growth of the Speakership has depended in part upon political ideas current when the government was founded, in part on the men who have filled the office and given form to unwritten laws, in part on the rise of new conditions which require a new system. When, in 1789 , the Speakership was established in the United States, the precedent which had most influence was the colonial Speaker. The two most noteworthy things about this officer were: first, that he had political responsibility; and, secondly, that he united with the functions of a moderator the rights of a member. We may find the cause of the retention by the colonial Speaker of his rights as a member, and of the different aspect which he thus presents from the Speaker of the House of Commons, in the circumstances of life in a new country and in the novel colonial ideas in regard to representation. The English conception is that each member of the House of Commons represents the whole of England, so that although a place may have no member in the Commons, it cannot be said to be unrepresented; hence when a member takes the chair his constituents do not feel that they lose a special privilege. In earliest colonial times representatives were considered only as committees to save the time and inconvenience required by primary assemblies; and, owing to the isolation of frontier communities, men of one place knew little of 
the wants of another. Thus the needs of a remote district would have been virtually ignored if its representative by becoming Speaker had lost his rights as a member. If the colonists would not give up their Speaker's representative character, they were not likely to be terrified by the fear of "one-man power" in the Speaker's chair. The House of Representatives never had in its mind that example of a presiding officer subservient to the king which has so affected the House of Commons. While the sovereignty in England has slowly passed from the Crown to Parliament, the Speaker has remained still the servant; while the sovereignty in the United States has passed from the privileged few to the many, the Speaker, the popular embodiment of resistance to the executive power, has assumed mastery. Hence there has never been, until very recently, any hesitation in conferring upon the Speaker powers that seemed necessary to promote the convenience of the House.

The steady development of the Speaker's powers shows, however, that there must be a force stronger organization of the House.
168. Imperfect

than tradition and more permanent than personal influence which tends to make the Speaker a party and parliamentary leader. To the peculiar organization of the House of Representatives is due above all the peculiar development of the Speakership. What is the fundamental characteristic of the House? Its lack of leadership. An assembly of men meet every year at Washington, all nominally equal in opportunity and power. In order to facilitate busi- 
ness the work of Congress was originally divided among a number of committees: power instead of being concentrated was purposely divided: it was supposed that through the committee system we should escape the evils of one-man control, that to divide power is to make it manageable. The result has been an entire lack of unity or coherence in legislation: there is no concerted action among the chairmen of the committees: no system has been framed to give any common character or purpose to measures introduced; they are to stand merely as the isolated results of isolated efforts. The majority of each committee are, to be sure, of one party; but the degree of success attained by the majority in their compromises with the minority varies greatly. Parties, moreover, are usually divided into factions, and the majority of each committee do not belong to the same faction. It would have been impossible for the committee system to have worked at all if the Speaker had not assumed more and more the leadership of the House. Our whole history goes to prove that one-man power is inevitable. The Speaker has supplemented the defects of our system of government by taking upon himself latitudes and privileges never allowed a mere moderator. In theory the Americans have always feared and restricted power; their history opposes their own theory.

The real reason why the Speaker uses his power of appointment of committees in a political fashion is that it was the way nearest at hand for getting any coherence out of the hodge-podge of com- 
mittee work. The Speaker's power over recognition seems tyrannical to the last degree, and the first tendency of every one is to cry out against it ; but the fundamental reason of its acceptance is that something must be done to unify legislation, that some one must be allowed to choose if anything is to be done. For the same reason has the Speaker received the control which he now possesses over the order of business through his position as chairman of the committee on Rules. His lesser powers of appointing the chairmen of the Committee of the Whole and Speakers protem. have not been given him purely for convenience: underneath the surface of conscious motives lies the fact that we absolutely must have a legislative leader, and we cannot have him if he have power to lead at some times but not at others: he must not only be allowed preëminence while in the chair, but when he is obliged temporarily to leave the chair he must place some one in it who will carry out his policy. One reason why the Speaker retains his rights as a member is that otherwise he cannot be a real leader. The habitual use of his parliamentary prerogatives for political ends has also arisen not because of the tendency to usurpation of power, nor because of the lethargy of the House of Representatives. Occasionally when a Carlisle or a Reed sits in the chair and boldly removes the veil which ordinary usage throws over it, we hear outcries against " a political moderator," and the House is censured for submitting to such arrogation of authority. But it must not be supposed 
that the House is too weak to control its presiding officer, or too ignorant and short-sighted to understand what he is doing. It feels, consciously or unconsciously, that to some one must be given the right of leadership. The Speaker has acquired it, first, because tradition did not exclude a political chairman; secondly, because our Speakers have been, on the whole, men ready to assume guidance; but, above all, because under the congressional system which has existed ever since 1789 , this power drifted most naturally to the presiding officer. The committee system has made necessary some unifying influence in legislation; and in this necessity lies really the whole secret of the Speaker's position.

To the imperfect organization of the House must, of course, be added the great increase in the amount of congressional business. Congress has proved more and more inefficient as the country has grown. "In the Fifty-first Congress," says McKee, "twenty thousand original propositions, classified as messages, bills, resolutions, petitions, and memorandums, were submitted to the House of Representatives for their action. If the House had been in session three hundred days of five hours each, and if all these propositions had received consideration, about four and a half minutes to each is all that could have been allowed. This would not have been sufficient to even read the measure once." 9 When one compares this amount of work with the few bills that were introduced in the first

- McKee, Red Book, 64. 
sessions of Congress, one cannot wonder that the body to which all this work goes has been forced to adapt itself to the changed conditions. The alternative was inadequacy and failure.

The Speakership had been little discussed outside the House until Mr. Reed made it famous. But we cannot give either Mr. Carlisle or 169. Centralization of power.

Mr. Reed the credit of inventing a political Speakership. The history of the House of Representatives shows that the consolidation of power has been an inevitable development. Individual men have only emphasized and perhaps hastened that development. The Fifty-first Congress, a Republican body, made a new code of rules increasing the Speaker's power; the Fifty-second and Fifty-third Congresses, Democratic bodies, also formally enlarged their chairman's authority, especially by giving very large power to a small committee of five men, the committee on Rules. Such instances show that, entirely irrespective of party tenets, there is at present an inevitable tendency towards the centralization of power. It is a force of such strength that party considerations fall before it. Its irresistible nature was hardly realized by the member who said a few years ago in Congress: "There seems to be a disposition, which I cannot understand, in this House to centralize, a doctrine which I had always supposed to be contrary to the sentiments and traditions of the Democratic party." 10 But in spite of party " sentiments and traditions," never before has the Democratic or ${ }^{10}$ Cong. Record, 52 Cong. I Sess., 670. 
the Republican party so fully recognized the principle of concentrated government. It has been perhaps unfortunate that giving power to the leaders has always meant with us taking it away from the individual members at the cost of jealousy and hard feeling. In the House of Commons the Premier has more authority than any of our leaders, but it coexists with greater power also on the part of the individual member.

The power of the Speaker seems not only inevitable but, under our present congressional system, x70. Necessity desirable. If he was intended to be a of making the moderator, then the charges of arbitraSpeaker re- ry and tyrannical usurpation of author-
sponsible.

ity are just, and the development of the Speakership one of the most deplorable facts in our history. Looked at as a great political officer, who, with definite legislative ends to reach, uses every opportunity to reach them, this development assumes an entirely different aspect. The one thing in the present position of the Speaker which is much to be regretted, and which will always tend to produce evil results until remedied, is the possession of such important prerogatives without definite responsibility. The first step towards remedying this state of things is a universal recognition of the Speaker's actual position; for although, as is shown above, the powers of this officer have been steadily gaining acquiescence in Congress, the mass of the people have been slow to grasp his real status in the House of Representatives. ${ }^{11}$ An amusing ${ }^{\text {n }}$ As late as the Eighth Congress it was denied that the Speaker 
commentary upon this lack of understanding was the attitude of the press in 1875 , when a Democratic Congress met in Washington for the first time for fifteen years. People were formally told that the Speaker was a powerful man who even appoints the committees. It was as though the country should suddenly be informed that the President nominates his Cabinet. Yet it was necessary then to point out the Speaker's position, and it is hardly less essential now. Until the great weight of the office is thoroughly understood, the Speaker will not be held by the people to the strict accountability which is the proper adjunct of power. That authority and responsibility should never be separated has now become an axiom; yet in the government of the United States they are separated in the Speakership. No assembly can be efficient without a recognized leader: this is a point upon which we should no longer deceive ourselves. The theory of the House is still that it is an assembly of equal factors, but the fact is that it is a hierarchy of private members, chairmen of committees, members of the committee on Rules, and above them all a Speaker. His status as the leader of the House of Representatives should be looked squarely in the face. That once accepted, there should be no delay in uniting power and responsibility.

had the power of appointing the chairman of the Committee of the Whole. "The Speaker merely nominates the Chairman of the Committee of the Whole under the pleasure of the House, who generally by their silence give a tacit consent which constitutes the appointment."-Annals of Congress, 8 Cong. 2 Sess., 697. 
Besides the inevitableness of this development, there are reasons for believing that the organized and

17x. Advantages of a responsible Speaker. - Increased efficiency and harmony of legislation. recognized responsibility of the Speaker will act as a corrective of some of the evils dwelt upon in all criticisms of our government. The central, vital fault of our political system is its lack of leadership. There is no one man or body of men whose duty it is to bring forward public measures. The result of the division of legislative initiative is legislative inefficiency. The little unity and coherence we have in legislation is due chiefly to the control which has been assumed by the Speaker. He should go further in this direction, and correct the present lack of recognized connection between the leaders. It is notorious that the national income is raised by one set of men, and the national expenditures managed by another. The division of the appropriation bills among several committees has caused a further lack of relation between income and outgo. The national executive has no power to remedy this or to prevent other kinds of legislation from being divided among various committees. The only solution seems to be to throw upon the Speaker the responsibility of compelling the adjustment of measures to one another, for he alone can do it. Upon him must also be laid the duty of bringing forward legislation needed by the country, and of pressing it to a vote. Such a power is safely exercised by the Premier in England, and could not be dangerous in America. 
Next to the lack of harmony in legislation the greatest evil of our government, and one almost x72. Possibility universally recognized, is the difficulty of fixing re- of knowing whom to hold accountable. sponsibility for The President may take it upon himself
legislation. to veto a measure or to let it pass; but no one can fix responsibility on a mixed committee or on any member of it. Professor Wilson suggests that the committees be composed wholly of majority members. But the present system is too firmly rooted for this suggestion to be adopted, and it would only add to the importance of the Speaker. To make the Speaker a responsible leader would undoubtedly add strength to our government: he would then come into office with a certain definite, declared policy; the country would have that pol: icy to look forward to, could see whether or not it was carried out, and could finally place upon him or his adversaries the responsibility for its success or failure. On the whole, the recent increase of the Speaker's power has worked conservatively: Carlisle took the responsibility of throttling the Blair Educational bill; Mr. Crisp refused with equal persistence to let a free-silver bill come to an open vote in the House, because the advocates of the measure were unable to present him a call for the necessary " rule" signed by a majority of the Democratic members.

The complaint is often made that we in America have no great statesmen; perhaps such burning questions as those of 1850 and 1860 would arouse great champions; perhaps, as admirers of the Eng- 
lish cabinet system say, "We have no great prizes of leadership such as are calculated to stimulate 173. Improve. men of strong talents to great and ment in the conspicuous public sevices." 2 But character of the increased power of the Speaker Representa- has done something to supply this tives.

defect in our system: as the recognition of his power has grown, the calibre of the Speakers has steadily increased. If still greater authority be given to the Speaker, if he become a recognized legislative leader responsible for the legislation of the United States, his office will be a prize little less valued than the Presidency. Perhaps then the hope of attaining the Speakership might induce able men to seek that legislative service which is almost an essential towards election to this office. The lesser leaders are certain to share in the prestige and influence of their chief, and the character of the House is likely thus to be materially improved.

Much just complaint is heard of the little interest felt in public affairs, especially in the proceedings 174. Increased popular interest in congres- it is almost impossible to follow the sional affairs. of Congress. This also will be affected by the increased power of the Speaker: action of fifty committees, disconnected and with no common principle; but every one can understand a leader, or a group of organized leaders, with some definite policy. Why is there so much interest already felt in the Speaker's election? It is not merely the personal interest in men; it is "Wilson, Congressional Government, 206. 
because people have learned to comprehend the significance of his election. Few people know just how powerful the Speaker is; but they are sure that the choice of $\mathrm{X}$ or $\mathrm{Y}$ will seriously affect the tariff and the silver question. When the Speaker comes to be understood in the popular mind to embody the motive force of the House, popular interest in congressional affairs will be greatly increased.

It might be asked, Is it not possible to get all these good results by choosing a political Speaker 175. Objections. and another man as an impartial moder- Combination ator? Those who propose this scheme of parliament- fail to take into account that if the cal duties.

Speaker's parliamentary duties were taken from him, he would no longer possess the same amount of political power. Unless committees are to be abolished, filibustering forgotten, and the legislation of Congress reduced to onefourth its present dimensions, the Speaker must have parliamentary power.

Another objection to the great power which the Speaker at present possesses is the feeling that it is undemocratic: as Dr. Snow said, "One 176. Concentration of power opposed to democracy. of the most difficult problems of democracy is to secure efficient legislation without a too great concentration of legislative powers." 12a But we cannot secure efficient legislation without a greater concentration of power than we have hitherto thought necessary. It would be absurd to retard our development by a too strict

${ }^{22 n}$ Freeman Snow, A Defence of Congressional Government (Papers of American Historical Association, IV, 127-8), 
adherence to an ideal of democracy impossible for a grcat nation; in State and even in city affairs we have long since passed the New England townmeeting of all the voters; the democracy most to be desired, then, is that in which the representative assembly shall legislate for those who elect it. As a matter of fact, Congress is incompetent to legislate wisely under the old conditions. It would certainly be advantageous to secure efficiency without concentration, were it possible. Even the Athenians knew that. There are certain truths, however, which we must accept if experience is to go for anything; and one of them is that the unregenerated House of Representatives is not and cannot be a legislative body.

It is sometimes urged that the Speaker's present political power is unconstitutional. Mr. Carlisle 177. Constitu- said in a recent article: "While the tional objec- right to enlarge or restrict these powtion.

ers, duties, and responsibilities by its own rules was expressly conferred upon the House of Representatives, it cannot be supposed that the authors of the Constitution intended by this clause to authorize the exercise of a power which would destroy or impair the free representative character of the body itself." 13 Without discussing the attitude of Speaker Carlisle toward Secretary Carlisle's dictum, it may be said that it is sometimes necessary to act in an extra-constitutional manner. As progress means change, we must be ready to supplement the text of the Constitution with un${ }^{13}$ North American Review, CL, $29 \mathrm{I}$. 
written principles unless we wish to end our days where we were placed by the statesmen of 1789 , and throw away the experience of a hundred years. Some one has said that a written constitution seems to exert a certain spell on the human mind, and we think of it not only as something absolutely fixed, but as absolutely right, as if there were a peculiar sacredness about it. It is necessary to recall to those who look upon the Constitution as a sacred and unalterable and complete body of law, that it was not laid down positively and arbitrarily as the only right form of government, or the best form of government, but adopted with great fear and foreboding as a possible solution of a difficult problem; that it rests upon a substratum of previous law and practice; and that its framers proceeded to add to it a body of statutes and practice which represent experience. To act unconstitutionally is criminal; to act in new ways parallel with the constitution is statesmanship.

Another very common characteristic in the attitude of all who oppose the Speaker's power is to stand back aghast at this " new and 178. Conserva- abnormal" development. Many con-
tive objection. servatives oppose it for no better reason than that it is " extraordinary and unheard of." But the political Speaker is the ordinary, the historical Speaker. From ancient times we find the chairmen of assemblies men of importance, possessing political powers. The Speaker of the House of Commons was formerly a political officer. The President of the French Chamber is a political offi- 
cer. The impartial moderator exists only where the cabinet system prevails. ${ }^{14}$ The attractive ideal of a non-party chairman has, during. the history of the House of Representatives, always struggled for mastery with the political Speaker; it has never been anything but a fiction. In great crises, when men's passions are aroused over vital things, they speak the truth in plain language. At such times the Speakership has been called a political office: It was thus spoken of as early as I8I2; the idea was universally expressed in 1855 . So when in 1890 men talked of a new departure, they were unconsciously following those who have ever closed their eyes to the real Speaker in the endeavor to keep up a fiction. The popular bugbear of one-man power comes in to urge that since authority may be abused it should not be conferred. The nation is so accustomed to the system of "checks and balances" that it is startled at the sight of a power to which the old checks do not apply, and fails to see that the new check of popular responsibility is more efficient.

Admitting all that may be said on the deficiencies of our congressional system, is the only remedy an 179. A natural increase in the powers of the Speaker? development The need in every large representative the wisest. assembly of what Mill calls a "legislative commission" is generally acknowledged. Professor Wilson and Mr. Gamaliel Bradford advocate that kind which directs the House of Com-

${ }^{14}$ In Norway the Presidents of the Storthing consult with the standing committees in regard to what measures shall be brought forward. -Dickinson, Procedure of Foreign Parliaments, II9. 
mons. This is not the place to enter into an argument on the merits of the Cabinet system for the United States; but its advocates sometimes forget the vast changes which would thus be necessitated, if not in the written Constitution, at least in our practical, working Constitution. If the Cabinet were merely allowed seats in Congress with the right of debate, they would have no power to bring before the-legislators measures upon which they desired a vote. If the Cabinet were made the leaders of Congress, there would be a tendency for the President to become the tool of his ministers. If the Cabinet were responsible to the House of Representatives, the Senate would probably soon occupy a subordinate position. And to all those who feel that a second chamber should be a real power rather than a nominal feature, to all who appreciate the representation of the States in a federal system, to all who recognize the dignified and valuable part which the Senate has played in the history of the United States, this must appear a grave and dangerous innovation. If it be possible to reach the same ends by means already accepted in Congress, it is plainly desirable. A recognition of the powers actually exercised by the Speaker and the committee on Rules would make them a legislative commission. This step would indeed make the Speaker a Premier; and if we were now to form a new government for the United States we should probably not decide to throw such responsibility on the presiding officer of the general assembly. But the great advantage of this solution of the problem is 
that it is a natural development. The question is not that of the best form of government abstractly, but of the form best for us at the present moment, in harmony with the actual working of our institutions. There is a strong presumption in favor of the result of the growth of years; the traditional part of the English constitution is as valuable as those parts which appear in statutes. The AngloSaxon race does not take kindly to making tabula rasa of existing government in order to found a new and perfect system. American government has proceeded by experience rather than by experiment. In order to improve our government we must first try to understand our political genius, to take into account present forces, and to watch the tendency of our institutions, and then we can make such alterations or advances as shall be directly in accordance with this tendency.

There are, of course, those who are satisfied with the old congressional system, who want the old way; but the old way has ceased to exist. Certain difficulties attendant on the methods of procedure in the House have been overcome by giving certain powers to the Speaker. If these are denied to him, the difficulties recur and must be overcome in some other way. The country does not stand still.

So far we have been looking upon the Speaker as 180. The Speaker as the head of the legisla. tive depart ment. a part of the House of Representatives. $\mathrm{He}$ has another status in the government. He represents more and more the headship of the whole legislative 
department. The Vice-President is a cipher; the President of the Senate unimportant. The one man who stands out of the two houses is the Speaker.

There was a time when this important position was occupied by the President of the United States, 188. Early su- who, with his official advisers, the Cabpremacy of ex- inet, was actually at the head of the ecutive.

government. In the first session of the First Congress, the departments not then being organized, Madison indeed took the lead, but his prominence was not due entirely to his ability or experience; it was largely because of his intimate relations with the President. As soon as the departments were organized, the executive made its influence felt more directly, and the messages and suggestions of the administration were the real basis of legislation. Secretary Knox even spoke in the Senate; and both Hamilton and Gallatin were readily followed by Congress. How inevitable was the supremacy of the President is shown by Jefferson's administration: one of the fundamental principles of the Republican party was to decrease the power of the executive, and to make it subordinate to the legislative; but circumstances were too much for Jefferson's theories, and he became the real head of the government. A legislature has, by its very nature, to follow leaders active either in the House or outside. The House in 1802 did not follow the President, it followed Jefferson, as it would have done if he had been in the House or in the Senate. Congress had few men of prominence during the two administrations of Jefferson: 
Breckinridge in the Senate and Randolph in the House were both bold and energetic; but they were new men, lacking prestige, and had yet to establish themselves as leaders. Jefferson, therefore, with his wonderful power of leadership, with his strict discipline and ready tactics, had Congress under his control. His success was due to the force of his own character. When he sent in his message in I 806, just when the United States were in danger of serious foreign complications, Macon appointed only one member of the committee on the message who would support the President; nevertheless Jefferson finally succeeded in getting the Two Million act through, although in the face of the most vigorous and determined opposition even from members of his own party. The Embargo of 1807 passed Congress on Jefferson's recommendation after a debate of scarcely three days in the House and four days in the Senate. John Quincy Adams said: "The President has recommended the measure on his high responsibility. I would not consider, I would not deliberate, I would act." 15

Professor Wilson attributes the early prominence of the executive department in great part to the 182. Causes. fact that the chief questions were then foreign affairs, in which the President was naturally predominant. But both Hamilton and Gallatin concerned themselves principally with home affairs; and in the war of 1812, when above all other times the President would naturally have exerted the greatest influence, Henry Clay led the ${ }^{10}$ Henry Adams, History of the United States, IV, 172-3. 
country from the chair of the House. It is impossible to say that the power of the Speaker had so grown within the twenty years that that position carried the leadership with it more naturally than the Presidency. We cannot doubt that if Henry Clay had been President instead of Speaker in I8I I, he would have been equally influential. The Presidents were usually followed because they were usually the ablest men. Contrast the early Presidents and Speakers. We have on the one hand Washington, Adams, and Jefferson; and on the other Muhlenberg, Trumbull, Dayton, Sedgwick, Macon, and Varnum, names which stand for nothing but a certain dignity and mediocrity. It was natural that at the beginning of our government the executive should have seemed more important than the legislative, and that the foremost men of the nation should have been chosen to occupy it.

In this long leadership of the President is the key to the status of the Speaker until about 1840 . 183. Relations The relation which the executive bore of the President to Congress during the first half of the and Speaker.

century is well manifested by the common division of parties in Congress into Administration and non-Administration members: it was the business of the former to carry through the President's recommendations and measures in the House; and the latter made it their pastime to oppose the executive policy, whatever it might be; the Administration party, moreover, was held responsible for executive suggestions; and when it happened that the President had a majority in 
the House, it was considered a breach of faith if it did not accomplish the measures proposed in the President's message. We see, then, how entirely different were the former relations between the coördinate departments from those which now exist. The Speaker's position in this state of things was either that of successful leader of the opposition, or one of subserviency to the President. Speaker White in his opening speech in $184 \mathrm{I}$ indicates the tendency: " The Chair should neither lend the influence of his position to make this House subservient to Executive dictation, nor, on the other hand, to encourage a factious opposition to Executive recommendations." 16 The candidates were commonly called Administration candidates and Opposition candidates; and the vote for Speaker was the first indication whether, or how far, the House was to support or to oppose the administration.

An extreme illustration of executive influence was Jefferson's plan for breaking up Randolph's coterie in order to stop their steady opposition. An attempt was made to overawe Monroe; Nicholson, Randolph's strongest supporter, was made Judge of the Maryland Circuit. "The Speaker remained to be dealt with," continues Mr. Adams in his account of this incident; " to buy him was out of the question; to crush him was only a last resort; no other resource was left than to coax him. 'Some enemy, whom we know not, is sowing tares between us,' wrote the President to the Speaker, at the moment when he was warning Monroe, and lifting Nicholson

${ }^{16}$ House Journal, 27 Cong. I Sess., 12. 
to the bench. 'Between you and myself nothing but opportunities of explanation can be necessary to defeat these endeavors. At least, on my part, my confidence in you is so unqualified that nothing further is necessary for my satisfaction." "17 Jefferson's tactics were successful. He infused his own ideas into the House, got rid of the most rebellious spirits, triumphed over the Speaker, and successfully dominated Congress. When Taylor, one of Adams's confidential friends, was elected Speaker in 1825 , it seemed a pledge to the country that Adams would be supported by the House; and Stevenson's election in 1827 showed a House in sharp opposition to the President.

Andrew Jackson ruled the country from 1829 to 1837, but it was a time when the House held few 884. The Speak- men of much force; Clay, Calhoun, er'spresentim- and Webster in the Senate were leadportance.

ers, but even they could not keep up a successful opposition to that masterful man. From Jackson to Lincoln there was not one commanding President, and the Speakers grew more important. After Lincoln, again, the principal Speakers were Blaine, Randall, Carlisle, and Reed, all natural leaders. Perhaps Judge Crisp's lesser reputation is due to the overshadowing influence of President Cleveland. Still all Speakers since the Civil War have been the real legislative chiefs of the United States. The reason we have not far to seek: the two most striking characteristics of our political

"Adams, History of United States, III, 167. Quoted from Jefferson to Macon, March 22, 1806; Jefferson's MSS. 
system are, first, the careful arrangement of "checks and balances" adopted to avoid the undue influence of any one department of government; secondly, the fear which it manifests of one-man power; consequently there is no position in our government which carries with it the leadership of the nation. If we have a man universally recognized as eminently fit for successful guidance, there is no one office, like the Premiership, to which we can elevate him. The looseness of our Constitution has had a remarkable effect upon every part of the government. A written constitution is supposed to be more rigid than an unwritten one, yet in some respects the Constitution of the United States is more elastic than many others, for it allows a freer development. It created officers to perform the various duties of the government, and then, instead of giving the chief power to any one, left them to fight it out among themselves. It would seem from the present brief sketch that under this system of government the headship falls to the real leaders wherever placed. That they have lately been placed in the chair of the House of Representatives is due to the increased authority of the Speaker, first in the House, and secondly outside the House through the increased power of the legislative over the executive. Ever since 1789 has been going on the strife for preeminence between the executive and legislative departments; the Presidents and Speakers have been champions of the two rivals. The internal development of Congress, and especially of the House, has shown the effects of the ever- 
renewed struggle. In I789-I79I both houses definitely refused to admit Cabinet officers to the floor. The creation of the committee of Ways and Means in 1794 was probably an effort of Congress to transfer to itself the influence of the Treasury department. In 1796 the House threatened to assume a veto power on treaties. As the committee system developed, Congress became more and more independent of executive influence. As it learned how to do things, it naturally wished to do them itself. During the Civil War the supremacy of Congress in legislation made great gains. Since that time we have no longer had Administration and non-Administration parties in Congress, simply because the President has had so slight a share in initiating the legislative policy. His message to Congress is really an address to the country and has no direct influence upon Congress. In the Fifty-third Congress, with a majority in the House of one hundred, specific and urgent recommendations of the President on pressing financial questions were ignored. A great part of the Speaker's power is due simply to the fact that the legislative now occupies the most important place in our government, and the Speaker reaps the fruits of that position. The President's influence over Congress has always been intermittent, and has now much diminished; the Speaker's power is constant, and gains with the growth of the nation, the increase of public business, and the larger share wrested by Congress from the President.

As a part of the increased power of Congress, the 
Speaker has gained a considerable influence over

185. The Speaker as an executive officer. Connection between legislative and executive. executive affairs. $\mathrm{He}$ affects the administration as well as the legislation of the country by his appointment of the Appropriation committees, the committees on the Army and Navy, on Pensions, on Public Buildings, and on the Judiciary. To be sure, the departments are theoretically quite distinct, but since the executive depends upon Congress for legislation in details and for money, the isolation implied by the Constitution does not exist. Neither is there that antagonism suggested by many critics of our government. Some of the latter are surprised that the system works at all under such an extraordinary state of things; but the reason why the government goes on is that in practice a harmony is reached which is not set forth in the paper Constitution. Politicians do not feel the great need of adjustment which theorists deplore. That there is no law of the United States requiring that $\mathrm{Mr}$. A, Secretary of the Treasury, confer at stated times with Mr. B, chairman of the committee on Ways and Means, is regarded by some of these writers as having the same effect as though there were a law forbidding Mr. A to consult Mr. B. But whenever it is to the mutual interest of Mr. A and Mr. B to meet, we may be very sure that they do so. Our government does not work in spite of the separation of legislative and executive; it works because there is not a complete separation. The English system of executive parliamentary responsibility is to some degree ex- 
ercised in Washington, although unacknowledged. When one party possesses all the branches of the government, although the case is rare, there may be considerable unity and concert of action. The committees of the House of Representatives, charged with the responsibility of framing legislation, avail themselves of all the information which they can obtain from all sources, and they do not neglect the very obvious sources of information to be found in the different departments. Concerning all estimates and appropriations, and all bills affecting any executive department, the secretaries of departments are in continual communication with the committees and their chairmen. In matters relating to the internal revenue laws, it is usual to consult with the Solicitor of the Treasury in regard to some of them, with the Commissioner of Internal Revenue in regard to others, and with the AttorneyGeneral as to the execution of proposed laws generally. When the administrative side of the bill in question has a political importance, then particularly is it natural that the administrative officers should be consulted. The connection between the departments is, to be sure, not official: it depends entirely on a common interest. There is constitutionally no difference between the committees' consulting the secretaries of departments and their consulting any private individual, and the system lacks the publicity which gives such point to the proceedings of the House of Commons.

The initiative, moreover, is not always taken by the legislative side. On very important measures 
the President frequently sends for and consults chairmen of committees and leaders generally in both House and Scnate. On some legislative matters the executive has weight by reason of the distribution of offices. In no other way, however, has the executive any predominance over the legis-

ive. His suggestions are often snubbed even

a Congress of his own party. Grant's desire or civil service reform, for instance, was treated with contempt by his friends in the House. When the tariff bill of the Fifty-first Congress was under discussion, the Secretary of State laid before the Republican members of the Ways and Means committee a proposition for reciprocity to be obtained by trade with foreign nations upon the basis of a release of sugar duties of those particular nations. The committee rejected this proposition because they did not believe that it would be advantageous. Undoubtedly there exists a connection more informal even than this irregular one of committee investigation and suggestion. The outside relations of leaders, legislators, and executive officers, though usually neglected by writers who dwell upon the separation of departments, are important, and much is done through the caucus and through private conferences. How much direct intercourse there is between the Speaker and President does not appear to the outside public, but there must often be a great deal. In i87 I Grant wrote a private letter to Speaker Blaine " earnestly counselling the prolongation of the session in order to pass a bill for the protection of life and property in the United States." 
Between Crisp and Cleveland there has been considerable understanding: the date of the adjournment of the last session was said to have been fixed by a conference of the Speaker and the President; ${ }^{18}$ it is probable that Crisp did all he could to get Cleveland to sign the Wilson Tariff bill.

There is, however, need of far greater unity in legislative initiative. The two great and acknowl186. Necessity edged defects of our present political of betteradjust. system are: first, lack of legislative ment.

leadership; and, secondly, the lack of connection between executive and legislative. ${ }^{19}$ But we have already a leader; we have an established system of connection. What is needed is to make that leadership more effective, and that connection between Cabinet and Congress more definite and intimate. One suggestion is to establish a formal council which will associate Speaker and President. ${ }^{20}$ The Speaker's part in this predominant council would, however, be loudly opposed. We should hear that the Constitution was being undermined, that

20 Boston Transcript, August 25, 1894 .

${ }^{20}$ The separation between the two Houses of Congress is also note. worthy. Measures have been approved and passed in both Houses which yet have not become laws because the Senate bill has not been passed in the House, or the House bill in the Senate. The Nation of 1873 says that there is somewhere in the reports of our Courts the history of a private claim of unquestionable merit, which was passed without opposition ten times by one House and fourteen by the other, and yet never succeeded in getting through both Houses of the same Congress.-Nation, XVI, 145 .

${ }^{20}$ See above, $\S 15$. The Speaker of the Pennsylvania Colonial Assembly was nearly always appointed on committees of Conference. See Journals of Pennsylvania, e. g. XXIX, 1682. 
the power was never contemplated which the Speaker now wields in the House, much less that which he would have in an executive council. Yet there was introduced in the Federal Convention of 1787 a clause for the establishment of a Council of State, of which the Speaker was to be a member. Such a council, however, would require a constitutional amendment, and hence is practically impossible. Yet, if the country really demands a change, the advantages of an over-committee may be had by private understanding. If the President should consult the Speaker before sending his message, and some agreement be concluded, then the presidential message would be a real force, and might be looked to as embodying the mature policy of the government in all departments.

The question of the Speaker's status is, however, only the question whether honest and adequate legislation may best be procured by separation of power with checks and balances, or by union of power with harmony and responsibility. There is much to be said on both sides. But it has been one of the objects of this work to show that, all theories aside, no matter what we want or what we do not want, the whole history of the House of Representatives, from an institutional point of view, has been the history of the concentration of legislative power in the hands of the Speaker of the House. 


\section{APPENDIX A.}

\section{BIBLIOGRAPHY OF THE SPEAKERSHIP.}

Adams, Henry. History of the United States of America. [1801-r817.] Ist ed. 9 vols. New York, 1889-189I.

Adams, John. Works. Io vols. Boston, I850-I 856 .

Adams, John Quincy. Memoirs. I2 vols. Philadelphia, 1874. 1877.

Aiken, Lucy. Memoirs of the Court of Queen Elizabeth. 2d ed. 2 vols. London, 1818 .

Anderson, Charles. A Funeral Oration of Henry Clay. Cincinnati, 1856 .

Barclay, John M. Constitution. Rules of House of Representatives. Digest, etc. Washington, 1875 .

Blaine, James G. Twenty Years of Congress. 2 vols. Norwich, Connecticut, 1856 .

Boston Transcript, The. 1854-1895.

Bourinot, John George. Parliamentary Procedure and Practice. Montreal, 1884.

Bradlaugh, Charles. The Rules, Customs. and Procedure of the House of Commons. London, 1859.

Brownlow, William G. Life of Henry Clav. Jonesborough, Tennessee, r884.

Bryce, James. The American Commonwealth. $2 d$ ed. 2 vols. London, r891.

Bryce, James. A Word as to the Speakership. North American Reviezu, CLI, 385-398. (1815-1895.)

Burnet, Gilbert. History of his Own Time. vols. London. 1724.

Carlisle, J. G. The Limitations of the Speakership. North American Review, CL, 390-399. (1815-1895.)

Chambers's Journal. London and Edinburgh, I $832-1895$.

Childs, David L. An Appeal from the editor of the Anti-Slavery Standard to the Abolitionists.

Clay, Henry. Personal Anecdotes, Incidents, etc. Anon. Harper's Magazine, V, 392-399. (1850-1895.) 
Cobbett, William. See Hansard.

Columbian Centinel, The. Boston, 1785-1840.

Congress, American, Journals of, 1774-1788. 4 vols. Washington, 1823 .

Congress of the United States of America :

Journals of, 1789-1895. 106 vols. Phila. and Wash., 1789-1895. Annals of, $1789-1824 . \quad 42$ vols. Wash., 1834-56.

Congressional Debates, 1824-1837. 29 vols. Wash., 1825-37.

Congressional Globe, 1833-1873. 108 vols. Wash., 1834-73.

Congressional Record, I873-I895. 27 vols. Wash., 1873-95.

Cox, Samuel S. Union, Disunion, Reunion. Three Decades. of Federal Legislation. Providence, R. I., I885.

Crocker, George Glover. Principles of Procedure. New York, I889.

Cushing, Luther Stearns. Elements of the Law and Practice of Legislative Assemblies in the United States of America. Boston, Is66.

Dallas, George Mifflin. The life and public services of J. K. Polk. 2d ed. Baltimore, 1844 .

Dickinson, Reginald. Summary of the rules and procedure of foreign parliaments. London, 1882 .

Elliot, Jonathan. Journal and Debates of the Federal Convention. 4 vols. Washington, 1830 .

Elsynge, Henry. The Ancient Method and Manner of holding Parliaments in England. 3d ed. London, 1675.

Fitch, Ashbel P. What Congress has done. North American Review, CLI, 524. (1815-1895.)

Foster, E. H. Funeral oration; delivered in Nashville, Tennessee, on the occasion of the celebration of the obsequies of Henry Clay ; July 28, 1852 . Nashville, 1852.

Gneist, Rudolph. The History of the English Constitution. 2 vols. New York, 1886.

Hallam, Henry. The Constitutional History of England. 5th ed. 3 vols. Paris, $\mathrm{IS} 4 \mathrm{r}$.

Hamilton, Alexander. Works. 9 vols. New York, 1886.

Hansard, Thomas Curson. The Parliamentary Debates, begun by W. Cobbett, and continued under the superintendence of T. C. Hansard. Ist series, $4 \mathrm{I}$ vols.; 2d series, 25 vols.; 3d series, vols. I-I 45. (Called at first The Parliamentary History of England.) London, $1803-1857$. 
Hart, Albert Bushnell. The Speaker as Premier. (In Practical Essays on American Government.) New York, 1893.

Hatsell, John. Precedents of Proceedings in the House of Commons. 2 vols. London, 1818.

Henry, William Wirt. Patrick Henry. Life, Correspondence, and Speeches. 3 vols. New York, 1891.

Higginson, Stephen. Ten Chapters in the Life of John Hancock. (Published first in 1789.) New York, 1857.

Hildreth, Richard. The History of the United States of America. 6 vols. New York, 1880 .

Jefferson, Thomas. Manual of Parliamentary Practice. Printed in Smith's Digest of the Rules of the House.

Johnston, Alexander. History of American Politics, 2d ed. New York, 1888.

Julian, George Washington. Life of Joshua R. Giddings. Chicago, 1892.

Julian, George Washington. Political Recollections, 1840-1872. Chicago, 1884.

Lex Parliamentaria : or a Treatise of the Law and Customs of Parliaments. - 2d ed. London, 1734.

Lodge, Henry Cabot. The Coming Congress. North American Review, CXLIX, 293-301. (1815-1895.)

Lords, Journals of House of, 1509-1832. Vols. 64, incomplete.

Macaulay, Thomas Babington. The History of England. 5 vols. Boston, 1856 .

McKee, Thomas Hudson. A Manual of Congressional Practice ; or, The United States Red Book. Washington, I892.

Madison, James. Journal of the Federal Convention. Edited by E. H. Scott. Chicago, 1893 .

Mansfield, J. B., and Kelsey, D. W. Personal Sketches of Members of 4 oth Congress. Baltimore, 1867.

Massachusetts, Journals of House of Representatives of. Boston, I780-1895.

Massachusetts Bay, Charters and Laws of the colony and province of. Boston, $18 \mathrm{I} 4$.

Massachusetts Bay, Journals of House of Representatives of, 1723-1777. Boston, I723-78.

Massey, William. History of England during the Reign of George III., 1745-1802. 4 vols. London, 1855-1863. 
May, Sir Thomas Erskine. A Treatise on the Law, Privileges, Practices, and Usages of Parliament. 6th ed. London, 1868.

Moore, A. Y. Life of Schuyler Colfax. Philadelphia, 1868.

Moore, J. W. History of North Carolina. 2 vols. Raleigh, 1880.

Morse, John Torrey. Abraham Lincoln. [American Statesmen.] 2 vols. Boston, 1893.

Nation, The. New York, 1865-95.

New Jersey Archives. 1631-1775. 18 vols. Trenton, I880-5. New York Assembly, Journals of. I69I-1799. Albany.

New York, Documents relating to Colonial History of. 15 vols. Albany, 1856-S7.

New York Tribune, The. $1841-95$.

New York World, The. I86I-1895.

Niles Register. 75 vols. Baltimore, $1812-1849$.

Palfrey, John Gorham. A Compendious History of the First . Century of New England. 3 vols. Boston, 1872.

Palgrave, Reginald F. D. The Ifouse of Commons. London, I869.

Parton, J. Herry Clay. North American Review, CII, 147-I94. (1815-1895.)

Pellew, William George. John Jay. [American Statesmen.] Boston, 1890 .

Pennsylvania, Votes and Proceedings of the House of Representatives of the Province of, 1682-1 776. 6 vols. Phila., 1752-76.

Poore, Benjamin Perley. The federal and state constitutions, colonial charters, and other organic laws. 2 vols. Washington, 1877.

Reed, Thomas B. The Limitations of the Speakership. North American Review, CL, 382-39o. (1815-1895.)

Reed, Thomas B. Reforms Needed in the House. North American Review, CL, 537-546. (1815-1895.)

Rhodes, James Ford. History of the United States from the Compromise of 1850 . 3 vols. New York, 1893-IS95.

Schouler, James. History of the United States of America under the Constitution. 5 vols. Washington, I880-I 891 .

Schurz, Carl. Henry Clay. [American Statesmen.] 2 vols. Boston, 1887 .

Smith, Henry H. Digest and Manual of the Rules and Practice of the House of Representatives. Irth ed. Washington, 1888.

Snow, Freeman. A Defense of Congressional Government. (In Papers of American Historical Association, Vol. IV, part 3.) 
Spectator, The. London, I828-1895.

Stanton, Theodore. The Quorum in European Legislatures. North American Review, CLIII, 737-749. (I815-1895.)

Statutes at Large of the United States. 28 vols. $1850-95$.

Statutes, Revised, of the United States. 2d ed. Wash., 1878. Supplement, I874-I89r, 2d ed. Wash., I89I.

Story, Joseph. Commentaries on the Constitution of the United States. 2 vols. Boston, 1851 .

Stranger in the House, The. Macmillan's Magazine, LXV, 476. (1859-1895.)

Stubbs, William. The Constitutional History of England. 2d ed. 3 vols. Oxford, 1875 .

Stubbs, William. Seventeen Lectures on the Study of Mediæval and Modern History. Oxford, 1886.

Townsend, George Alfred. Washington. Outside and inside. Hartford, 1873.

Walpole, Spencer Horatio. The electorate and the legislature. [The English Citizen.] London, 1892.

Walpole, Spencer Horatio. A History of England. 5 vols. London, I878-I886.

Wentworth, John. Congressional Reminiscences. Chicago, 1882.

Wilson, Woodrow. Congressional Government. Boston, I885.

Winthrop, Robert C. Memoir of Henry Clay. Cambridge, 1880.

United States Reports. Decisions of Supreme Court. I7901895. Vols. I59. I88I-1896.

X. M. C. Speaker Reed's Error. North American Review, CLI, 90-III. (1815-1895.)

\section{APPENDIX B.}

LIST OF THE PRESIDENTS OF THE CONTINENTAL CONGRESSES AND THE CONGRESS OF THE CON. FEDERATION (I774-I788).

1774, Sept. 5-Oct. 22, I774, Peyton Randolph, of Virginia.

Election : Journals of Congress, I, I.

1774, Oct. 22-Oct. 26, I774, Henry M:ddleton, of South Carolina. Election : Journals of Congress, I, 39. 
1775, May ro-May 19, 1775, Peyton Randolph, of Virginia. Election : Journals of Congress, I, 50.

1775, May 19-Oct. 31, 1777, John Hancock, of Massachusetts. Election: Journals of Congress, I, 72.

1777, Nov. I-Dec. 9, 1778, Henry Laurens, of South Carolina. Election : Journals of Congress, II, 309.

1778, Dec. Io-Sept. 28, I779, John Jay, of New York.

Election : Journals of Congress, III, $\mathrm{x} 5 \mathrm{r}$.

1779, Sept. 28-July ro, 1781, Samuel Huntington, of Connecticut. Election: Journals of Congress, III, 368.

I78I, July 10-Oct. 23, I78I. Thomas McKean, of Delaware. Election: Journals of Congress, III, 644.

1781, Nov. 3-Nov. 2, 1782, John Hanson, of Maryland. Election : Journals of Congress, III, 685.

1782, Nov. 4-Nov. I, 1783, Elias Boudinot, of New Jersey. Election : Journals of Congress, IV, IO2.

1783, Nov. 3-June 3, 7784 , Thomas Mifflin, of Pennsylvania. Election : Journals of Congress, IV, 3 I 4 .

1784, Nov. 30-Nov. 4, 1785 , Richard Henry Lee, of Virginia. Election : Journals of Congress, IV, 448.

1785, Nov. 23-June 6, $x 786,{ }^{1}$ John Hancock, of Massachusetts. Election: Journals of Congress, IV, 606.

1786, June 6-Nov. 3, 1786, Nathaniel Gorham, of Massachusetts. Election: Journals of Congress, IV, 652.

1787, Feb. 2-Oct. 30, 1787, Arthur St. Clair, of Pennsylvania.

Election: Journals of Congress, IV, 719. 1788, Jan. 22-Nov, , 1,1788 , Cyrus Griffin, of Virginia.

Election: Journals of Congress, IV, 806 .

\section{APPENDIX C.}

LIST OF THE SPEAKERS OF THE HOUSE OF REPRESENTATIVES (1789-1895). ${ }^{2}$

I789, Apr. I-Mar. 3, I79I, (I) Frederick A. Muhlenberg, of Pennsylvania.

Election: House Journal, I Cong. I Sess., 6.

1 Hancock was ill and could not act during this time.

' Before ${ }^{18} 8^{1}$ the result of the balloting for Speaker was often omitted in the records. 
1791, Oct. 24-Mar. 2, 1793, Jonathan Trumbull, of Connecticut.

Election: House Journal, 2 Cong. I Sess., 434.

1793, Dec. 2-Mar. 3, 1795, (2) Frederick A. Muhlenberg, of Pennsylvania.

Election : House Journal, 3 Cong. I Sess., 5.

1795. Dec. 7-Mar. 3, 1797, (1) Jonathan Dayton, of New Jersey.

Election: House Journal, 4 Cong. I Sess., 5.

1797, Nov. 13-Mar. 3, I799, (2) Jonathan Dayton, of New Jersey.

Election: House Journal, 5 Cong. I Sess., 5.

1799, Dec. 2-Mar. 3, 1801, Theodore Sedgwick, of Massachusetts.

Election: Sedgwick, 42 ; Macon, of North Carolina, 27 ; scattering, 16." Annals of Congress, 6 Cong. I Sess., 186.

1801, Dec. 7-Mar. 3, 1803, (1) Nathaniel Macon, of North Carolina.

Election: House Journal, 7 Cong. I Sess., 5.

1803, Oct. 17-Mar. 3, 1805, (2) Nathaniel Macon, of North Carolina.

Election: House Journal, 8 Cong. I Sess., 6.

1805, Dec. 2-Mar. 3, 1807, (3) Nathaniel Macon, of North Carolina.

Election : House Journal, 9 Cong. I Sess., 6.

1807, Oct. 26-Mar. 3, 1809, (I) Joseph B. Varnum, of Massachusetts.

Election: Varnum, 59 ; scattering, 58. Annals of Congress, ro Cong. I Sess., 782.

I809, May 22-Mar. 3, I811, (2) Joseph B. Varnum, of Massachusetts.

Election: Varnum, 60; Macon, 36; scattering, 24. Annals of Congress, 11 Cong. 1 Sess., 55.

1811, Nov. 4-Mar. 3, 1813, (I) Henry Clay, of Kentucky.

Election : House Journal, 12 Cong. I Sess., 6.

1813, May 24-Jan. 19, I814, (2) Henry Clay, of Kentucky.

Election : Clay, 89; Timothy Pitkin, of Connecticut, 54 ; scattering, 5. Annals of Congress, 13 Cong. I Sess., 106.

1814, Jan. I9-Mar. 3, 1815, Langdon Cheves, of South Carolina.

Election : Cheves, 94 ; Felix Grundy, of Tennessee, 59 ; scattering, 12. Annals of Congress, 13 Cong. 1 Sess., 1057.

1815, Dec. 4-Mar. 3, 1817, (3) Henry Clay, of Kentucky.

Election : House Journal, 14 Cong. I Sess., 7.

1817, Dec. I-Mar. 3, 1819, (4) Henry Clay, of Kentucky.

The votes given represent in every case the votes on the final ballot. 
Election: Clay, I43; Smith, of Maryland, 6 ; blank, 1. Annals of Congress, 15 Cong. I Sess., 398.

1819, Dec. 6-Nov. 15, I820, (5) Henry Clay, of Kentucky.

Election : Clay, 147 ; scattering, 8. Annals of Congress, 16 Cong. I Sess., 702 .

I820, Nov, 15-Mar. 3, I821, (1) John W. Taylor, of New York.

Election : Taylor, 76 ; Lowndes, of South Carolina, 44 ; Smith, of Maryland, 27 ; scattering, 1. Annals of Congress, 16 Cong. 2 Sess., 438.

I821, Dec. 4-Mar. 3, IS23, Philip C. Barbour, of Virginia.

Election: Barbour, 88; Taylor, 67 ; scattering, 17. Annals of Congress, 17 Cong. I Sess., 516.

1823, Dec. I-Mar. 3, I825, (6) Henry Clay, of Kentucky.

Election: Clay, 139; Barbour, 42. Annals of Congress, 18 Cong. I Sess., 795.

1825, Dec. 5-Mar. 3, 1827, (2) John W. Taylor, of New York.

Election: Taylor, 99 ; J. W. Campbell, of Ohio, 42 ; Louis McLane, 44 ; scattering, 8. Annals of Congress, 19 Cong. I Sess., 775.

1827, Dec. 3-Mar. 3, 1829, (I) Andrew Stevenson, of Virginia.

Election: Stevenson, 104; Taylor, 94 ; scattering, 7. Annals of Congress, 20 Cong. I Sess., 811 .

1829, Dec. 7-Mar. 3, 1831, (2) Andrew Stevenson, of Virginia.-

Election: House Journal, 21 Cong. I Sess., 7.

1831, Dec. 5-Mar. 3, 1833, (3) Andrew Stevenson, of Virginia.

Election: Stevenson, 98 ; J. B. Sutherland, of Pennsylvania, 54 scattering, 4I. Debates of Congress, 22 Cong. I Sess., r4I9.

1833, Dec. 2-June 30, 1834, (4) Andrew Stevenson, of Virginia.

Election: Stevenson, 142 ; Lewis Williams, of North Carolina, 39; scattering, 36. Debates of Congress, 23 Cong. I Sess., 2136.

1834, June 30-Mar. 3, I835, John Bell, of Tennessee.

Election : Bell, 114; Polk, 78 ; scattering, 20. Debates of Congress, 23 Cong. I Sess., 4373.

1835, Dec. 7-Mar. 3, I837, (I) James K. Polk, of Tennessee.

Election: Polk, 132: Bell, 84: scattering, 9. Debates of Cong., 24 Cong. I Sess., 1945.

1837, Sept. 5-Mar. 3, 1839, (2) James K. Polk, of Tennessee.

Election: Polk, II6; Bell, I03; scattering, 5. Debates of Cong., 25 Cong. I Sess., 560. 
1839, Dec. 14-Mar. 3, I841, Robert M. T. Hunter, of Virginia.

Election: Hunter, II9; John W. Jones, of Virginia, 55 ; scattering, 58. House Journal, 26 Cong. I Sess., 79-80.

1841, May 31-Mar. 3, I843, John White, of Kentucky.

Election: White, I21 ; Jones, 84; scattering, 16. House Journal, 27 Cong. I Sess., II.

1843, Dec. 4-Mar. 3, I845, John W. Jones, of Virginia.

Election, Jones, 128 ; John White, 59 ; scattering, I. House Journal, 28 Cong. I Sess., 8.

1845, Dec. I-Mar. 3, 1847, John W. Davis, of Indiana.

Election: Davis, I20; S. F. Vinton, of Ohio, $7 \mathrm{I}$; scattering, 19. House Journal, 29 Cong. I Sess., 9.

1847, Dec. 6-Mar. 3, 1849, Robert C. Winthrop, of Massachusetts.

Election: Winthrop, 108; Linn Boyd, 6I; scattering, 19. House Journal, 30 Cong. I Sess., 14.

1849, Dec. 22-Mar. 3, 1851, Howell Cobb, of Georgla.

Election: Cobb, 102; Winthrop, 100; scattering, 20. House Journal, 3r Cong. I Sess., r63-4.

1851, Dec. I-Mar. 3, 1853, (I) Linn Boyd, of Kentucky.

Election : Boyd, II8; scattering, 96. House Journal, 32 Cong. I Sess., Io.

1853, Dec. 5-Mar. 3, 1855, (2) Linn Boyd, of Kentucky.

Election: Boyd, 143; scattering, 74. House Journal, 33 Cong. I Sess., Io.

1856, Feb. 2-Mar. 3, I857, Nathaniel Banks, of Massachusetts.

Election: Banks, I03; Aiken, of South Carolina, I00; scat. tering, II. House fournal, 34 Cong. I Sess., 444.

1857, Dec. 7-Mar. 3, 1859, James L. Orr, of South Carolina.

Election: Orr, 128 ; Grow, of Pennsylvania, 84 ; scattering, 53. House Journal, 35 Cong. I Sess., ro.

1860, Feb. I-Mar. 3, I861, William Peninington, of New Jersey.

Election: Pennington, II 7 ; scattering, Ir6. House Journal, 36 Cong. I Sess., I63-4.

I86I, July 4-Mar. 3, I863, Galusha A. Grow, of Pennsylvania.

Election: Grow, 99; scattering, 60. House fournal, 37 Cong. I Sess., 9.

1863, Dec. 7-Mar. 3, I865, (I) Schuyler Colfax, of Indiana.

Election : Colfax, IOI ; Cox, of Delaware, 42 ; scattering, 39. House Journal, 38 Cong. I Sess., II.

1865, Dec. 4-Mar. 3, 1867, (2) Schuyler Colfax, of Indiana. 
Election: Colfax, 139; Brooks, of Connecticut, 36. House Journal, 39 Cong. I Sess., 8.

1867, Mar. 4-Mar. 3, 1869, (3) Schuyler Colfax, of Indiana.

Election: Colfax, 127 ; Marshall, of Illinois, 30. House Journal, 40 Cong. I Sess., 7 .

1869, Mar. 3-Mar. 3, 1869, Theodore M. Pomeroy, of New York.

Election: unanimous. House Journal, 40 Cong. 3 Sess., 513.

1869, Mar. 4-Mar. 3, I871, (1) James G. Blaine, of Maine.

Election : Blaine, 135 ; Kerr, of Indiana, 57. House Journal, 4I Cong. I Sess., 9.

1871, Mar. 4-Mar. 3, I873, (2) James G. Blaine, of Maine.

Election: Blaine, I26; Morgan, of Ohio, 93. House Journal, 42 Cong. I Sess., 9.

1873, Dec. I-Mar. 3, 1875, (3) James G. Blaine, of Maine.

Election: Blaine, 189; Wood, of New York, 77 ; scattering, 4. House Journal, 43 Cong. I Sess., Io.

1875, Dec. 6-Aug. 15, 1876, Michael C. Kerr, of Indiana.

Election: Kerr, 173; Blaine, ro6; scattering, 3. House Journal, 44 Cong. I Sess., 10.

I876, Dec. 4-Mar. 3, 1877, (I) Samuel J. Randall, of Pennsylvania.

Election : Randall, 162 ; Garfield, 82 ; scattering, 3. House Journal, 44 Cong. 2 Sess., II.

1877, Oct. 15-Mar. 3, I879, (2) Samuel J. Randall, of Pennsylvania.

Election: Randall, 149; Garfield, 132. House Journal, 45 Cong. I Sess., II.

1879, Mar. I8-Mar. 3, I88 I, (3) Samuel J. Randall, of Pennsylvania.

Election: Randall, 144 ; Garfield, 125 ; scattering, 14. House Journal, 46 Cong. I Sess., II.

1881, Dec. 5-Mar. 3, 1883, J. Warren Keifer, of Ohio.

Election: Keifer, 148; Randall, 129; scattering, 8. House Journal, 47 Cong. I Sess., Io.

1883, Dec. 3-Mar. 3, 1885, (I) John G. Carlisle, of Kentucky.

Election : Carlisle, I9I ; Keifer, II2 ; scattering, 5. House Journal, 48 Cong. I Sess., Ir.

1885, Dec. 7-Mar. 3, 1887, (2) John G. Carlisle, of Kentucky.

Election : Carlisle, 178 ; Reed, 138. House Journal, 49 Cong. I Sess., II. 
1887, Dec. 5-Mar. 3, 1889, (3) John G. Carlisle, of Kentucky.

Election : Carlisle, 163 ; Reed, 147; scattering, 2. House Journal, 50 Cong. I Sess., II.

1889, Dec. 2-Mar. 4, I89I, (I) Thomas B. Reed, of Maine.

Election: Reed, I66 ; Carlisle, 154; scattering, I. House Journal, 5 I Cong. I Sess., 5.

1891, Dec. 7-Mar. 3, I893, (1) Charles F. Crisp, of Georgia.

Election: Crisp, 228; Reed, 83; scattering, 8. House Journal, 52 Cong. I Sess., 5.

1893, Aug. 7-Mar. 3, 1895, (2) Charles F. Crisp, of Georgia.

Election : Crisp, 212 ; Reed, 121 ; Jerry Simpson, of Kansas, 9. House Journal, 53 Cong. I Sess., 7.

\section{APPENDIX D.}

\section{RULES OF THE HOUSE OF REPRESENTATIVES.}

\section{FIFTY-THIRD CONGRESS.}

\section{Rule I.-Duties of the Speaker.}

I. The Speaker shall take the chair on every legislative day precisely at the hour to which the House shall have adjourned at the last sitting, immediately call the Members to order, and on the appearance of a quorum, cause the Journal of the proceedings of the last day's sitting to be read, having previously examined and approved the same.

2. He shall preserve order and decorum, and in case of disturbance or disorderly conduct in the galleries, or in the lobby, may cause the same to be cleared.

3. He shall have general control, except as provided by rule or law, of the Hall of the House, and of the corridors and passages, and the disposal of the unappropriated rooms in that part of the Capitol assigned to the use of the House until further order.

4. He shall sign all acts, addresses, joint resolutions, writs, warrants, and subpœnas of, or issued by order of, the House, and decide all questions of order, subject to an appeal by any Member, on which appeal no Member shall speak more than once, unless by permission of the House.

5. He shall rise to put a question, but may. state it sitting; and shall 
put questions in this form, to wit: "As many as are in favor (as the question may be) say $A y$;" and after the affirmative voice is expressed, "As many as are opposed say $N o$;" if he doubts, or a division is called for, the House shall divide; those in the affirmative of the question shall first rise from their seats, and then those in the negative; if he still doubts, or a count is required by at least one-fifth of a quorum, he shall name one from each side of the question, to tell the Members in the affirmative and negative; which being reported, he shall rise and state the decision.

6 . He shall not be required to vote in ordinary legislative proceedings, except when his vote would be decisive, or where the House is engaged in voting by ballot; and in all cases of a tie vote the question shall be lost.

7. He shall have the right to name any Member to perform the duties of the Chair, but such substitution shall not extend beyond an adjournment : Provided, hozvever, That in case of his illness he may make such appointment for a period not exceeding ten days, with the approval of the House at the time the same is made; and in his absence and omission to make such appointment, the House shall proceed to elect a Speaker pro tempore, to act during his absence.

\section{Rule II.-Election of Officers.}

There shall be elected by a viva voce vote at the commencement of each Congress, to continue in office until their successors are chosen and qualified, a Clerk, Sergeant-at-Arms, Doorkeeper, Postmaster, and Chaplain, each of whom shall take an oath to support the Constitution of the United States, and for the true and faithful discharge of the duties of his office, to the best of his knowledge and ability, and to keep the secrets of the House, and each shall appoint all of the employees of his department provided for by law.

\section{Rule III.-Duties of the Clerk.}

I. The Clerk shall, at the commencement of the first session of each Congress, call the Members to order, proceed to call the roll of Members by States in alphabetical order, and, pending the election of a Speaker or Speaker pro tempore, preserve order and decorum, and decide all questions of order, subject to appeal by any Member.

2. He shall maike, and cause to be printed and delivered to each Member, or mailed to his address, at the commencement of every regular session of Congress, a list of the reports which it is the duty 
of any officer or Department to make to Congress, referring to the act or resolution and page of the volume of the laws or journal in which it may be contained, and placing under the name of each officer the list of reports required of him to be made; also make a weekly statement of the resolutions and bills upon the Speaker's table, accompanied with a brief reference to the orders and proceedings of the House upon each, and the dates of such orders and proceedings, which statement shall be printed.

3. He shall note all questions of order, with the decisions thereon, the record of which shall be printed as an appendix to the Journal of each session; and complete, as soon after the close of the session as possible, the printing and distribution to Members and Delegates of the Journal of the House, together with an accurate and complete index; retain in the library at his office, for the use of the members and officers of the House, and not to be withdrawn therefrom, two copies of all the books and printed documents deposited there; send, at the end of each session, a printed copy of the Journal thereof to the executive and to each branch of the legislature of every State and Territory; preserve for and deliver or mail to each Member and Delegate an extra copy, in good binding, of all documents printed by order of either House of the Congress to which he belonged; attest and affix the seal of the House to all writs, warrants, and subpœnas issued by order of the House; certify to the passage of all bills and joint resolutions; make or approve all contracts, bargains, or agreements relative to furnishing any matter or thing, or for the performance of any labor for the House of Representatives, in pursuance of law or order of the House ; keep full and accurate accounts of the disbursements out of the contingent fund of the House ; keep the stationery accounts of Members and Delegates, and pay them as provided by law. He shall pay to the officers and employés of the House of Representatives, on the last day of each month, the amount of their salaries that shall be due them; and when the last day of the month falls on Sunday he shall pay them on the day next preceding.

\section{Rule IV.-Duties of the Sergeant-at-Arms.}

I. It shall be the duty of the Sergeant-at-Arms to attend the House during its sittings, to maintain order under the direction of the Speaker, and pending the election of a Speaker or Speaker pro tempore, under the direction of the Clerk, execute the commands of 
the House, and all processes issued by authority thereof, directed to him by the Speaker; keep the accounts for the pay and mileage of Members and Delegates, and pay them as provided by law.

2. The symbol of his office shall be the mace, which shall be borne by him while enforcing order on the floor. ${ }^{1}$

\section{Rule V.-Duties of Other Officers.}

I. The Doorkeeper shall enforce strictly the rules relating to the privileges of the Hall and be responsible to the House for the official conduct of his employés.

2. At the commencement and close of each session of Congress he shall take an inventory of all the furniture, books, and other public property in the several committee and other rooms under his charge, and report the same to the House, which report shall be referred to the Committee on Accounts, to ascertain and determine the amount for which he shall be held liable for missing articles.

3. He shall allow no person to enter the room over the Hall of the House during its sittings; and fifteen minutes before the hour for the meeting of the House each day he shall see that the floor is cleared of all persons, except those privileged to remain, and kept so until ten minutes after adjournment.

\section{Rule VI.}

The Postmaster shall superintend the post-office kept in the Capitol for the accommodation of Representatives, Delegates, and officers of the House, and be held responsible for the prompt and safe delivery of their mail.

\section{Rule VII.}

The Chaplain shall attend at the commencement of each day's sitting of the House and open the same with prayer.

\section{Rule VIII.-Of the Members.}

r. Every Member shall be present within the Hall of the House during its sittings, unless excused or necessarily prevented ; and shall vote on each question put, unless he has a direct personal or pecuniary interest in the event of such question.

2. Pairs shall be announced by the Clerk, after the completion of

1 Before the Fifty-second Congress this rule contained a third clause: "He shall give bond," ctc. 
the second roll call, from a written list furnished him, and signed by the Member making the statement to the Clerk, which list shall be published in the Record as a part of the proceedings, immediately following the names of those not voting: Provided, That pairs shall be announced but once during the same legislative day.

\section{Rule IX.-Questions of Privilege.}

Questions of privilege shall be, first, those affecting the rights of the House collectively, its safety, dignity, and the integrity of its proceedings ; second, the rights, reputation, and conduct of Members individually in their representative capacity only; and shall have precedence of all other questions, except motions to fix the day to which the House shall adjourn, to adjourn, and for a recess.

\section{Rule X.-Of Committees.}

I. Unless otherwise specially ordered by the House, the Speaker shall appoint, at the commencement of each Congress, the following standing committees, viz. :

On Elections, to consist of fifteen members.

On Ways and Means, to consist of seventeen members.

On Appropriations, to consist of seventeen members.

On the Judiciary, to consist of seventeen members.

On Banking and Currency, to consist of seventeen members.

On Coinage, Weights, and Measures, to consist of seventeen members.

On Interstate and Foreign Commerce, to consist of seventeen members.

On Rivers and Harbors, to consist of seventeen members.

On the Merchant Marine and Fisheries, to consist of thirteen members.

On Agriculture, to consist of seventeen members.

On Foreign Affairs, to consist of fifteen members.

On Military Affairs, to consist of fifteen members.

On Naval Affairs, to consist of fifteen members.

On the Post-Office and Post-Roads, to consist of fifteen members.

On the Public Lands, to consist of fifteen members.

On Indian Affairs, to consist of fifteen members.

On the Territories, to consist of thirteen members.

On Railways and Canals, to consist of thirteen members.

On Manufactures, to consist of eleven members, 
On Mines and Mining, to consist of thirteen members.

On Public Buildings and Grounds, to consist of fifteen members.

On Pacific Railroads, to consist of fifteen members.

On Levees and Improvement of the Mississippi River, to consist of thirteen members.

On Education, to consist of thirteen members.

On Labor, to consist of thirteen members.

On the Militia, to consist of thirteen members.

On Patents, to consist of thirteen members.

On Invalid Pensions, to consist of fifteen members.

On Pensions, to consist of thirteen members.

On Claims, to consist of fifteen members.

On War Claims, to consist of thirteen members.

On Private Land Claims, to consist of thirteen members.

On the District of Columbia, to consist of fifteen members.

On Revision of the Laws, to consist of thirteen members.

On Reform in the Civil Service, to consist of thirteen members.

On Election of President, Vice-President, and Representatives in Congress, to consist of thirteen members.

On Alcoholic Liquor Traffic, to consist of eleven members.

On Irrigation of Arid Lands, to consist of eleven members.

On Immigration and Naturalization, to consist of eleven members.

On Ventilation and Acoustics, to consist of seven members.

On Expenditures in the State Department, to consist of seven members.

On Expenditures in the Treasury Department, to consist of seven members.

On Expenditures in the War Department, to consist of seven members.

On Expenditures in the Navy Department, to consist of seven members.

On Expenditures in the Post-Office Department, to consist of seven members.

On Expenditures in the Interior Department, to consist of seven members.

On Expenditures in the Department of Justice, to consist of seven members.

On Expenditures in the Department of Agriculture, to consist of seven members.

On Expenditures on Public Buildings, to consist of seven members. 
On Rules, to consist of five members.

On Accounts, to consist of nine members.

On Mileage, to consist of five members.

Also the following joint standing committees, viz. :

On the Library, to consist of three members.

On Printing, to consist of three members.

On Enrolled Bills, to consist of seven members.

2. He shall also appoint all select committees" which shall be ordered by the House from time to time.

3. The first-named Member of each committee shall be the chairman ; and in his absence, or being excused by the House, the nextnamed Member, and so on, as often as the case shall happen, unless the committee by a majority of its number elect a chairman.

4. The chairman shall appoint the clerk of his committee, subject to its approval, who shall be paid at the public expense, the House having first provided therefor.

\section{Rule XI.-Powers and Duties of Committees.}

All proposed legislation shall be referred to the committees named in the preceding rule, as follows, viz. : Subjects relating-

I. to the election of members : to the Committee on Elections ;

2. to the revenue and such measures as purport to raise revenue and the bonded debt of the United States: to the Committee on Ways and Means ;

3. to appropriation of the revenue for the support of the Government as herein provided, viz., for legislative, executive, and judicial expenses; for sundry civil expenses; for fortifications and coast defenses ; for the District of Columbia ; for pensions ; and for all deficiencies : to the Committee on Appropriations ;

4. to judicial proceedings, civil and criminal law : to the Committee on the Judiciary ;

5. to banking and currency : to the Committee on Banking and Currency ;

6. to coinage, weights, and measures : to the Committee on Coinage, Weights, and Measures ;

7. to commerce, life-saving service and light-houses, other than appropriations for life-saving service and light-houses : to the Committee on Interstate and Foreign Commerce ;

" and conference committecs" omitted. 
8. to the improvement of rivers and harbors : to the Committee on Rivers and llarbors ;

9. to the merchant marine and fisheries: to the Committee on the Merchant Marine and Fisherics ;

10. to agriculture and forestry : to the Committee on Agriculture, who shall receive the estimates and report the appropriations for the Agricultural Department ;

II. to the relations of the United States with foreign nations, including appropriations therefor: to the Committee on Foreign Affairs.

12. to the military establishment and the public defense, including the appropriations for its support and for that of the Military Academy : to the Committee on Military Affairs ;

I3. to the naval establishment, including the appropriations for its support: to the Committee on Naval Affairs ;

I4. to the post-office and post-roads, including appropriations for their support : to the Committee on the Post-Office and Post-Roads ;

I5. to the lands of the United States: to the Committee on the Public Lands ;

I6. to the relations of the United States with the Indians and the Indian tribes, including appropriations therefor; to the Committee on Indian Affairs ;

I7. to Territorial legislation, the revision thereof, and affecting Territories or the admission of States: to the Committee on the Territories ;

18. to railways and canals, other than Pacific railroads; to the Committee on Railways and Canals ;

I9. to the manufacturing industries : to the Committee on Manufactures;

20. to the mining interests: to the Committee on Mines and Mining;

21. to the public buildings and occupied or improved grounds of the United States, other than appropriations therefor: to the Committee on Public Buildings and Grounds;

22. to the railroads and telegraphic lines between the Mississippi River and the Pacific coast : to the Committee on Pacific Railroads ;

23. to the levees of the Mississippi River: to the Committee on Levees and Improvements of the Mississippi River;

24. to education: to the Committee on Education ;

25. to and affecting labor : to the Committee on Labor;

26. to the militia of the several States: to the Committee on the Militia ; 
27. to patents, copyrights, and trade-marks : to the Committee on Patents ;

28. to the pensions of the civil war : to the Committee on Invalid Pensions ;

29. to the pensions of all the wars of the United States, other than the civil war: to the Committee on Pensions ;

30. to private and domestic claims and demands, other than war claims, against the United States : to the Committee on Claims ;

3r. to claims arising from any war in which the United States has been engaged : to the Committee on War Claims ;

32. to private claims to lands; to the Committee on Private Land Claims ;

33. to the District of Columbia, other than appropriations therefor : to the Committee on the District of Columbia ;

34. to the revision and codification of the statutes of the United States : to the Committee on the Revision of the Laws;

35. to reform civil service: to the Committee on Reform in the Civil Service ;

36. to the election of the President, Vice-President or Representatives in Congress : to the Committee on Election of President, VicePresident and Representatives in Congress ;

37. to alcoholic liquor traffic: to the Committee on Alcoholic Liquor Traffic ;

$3 S$. to the irrigation of arid lands ; to the Committee on Irrigation of Arid Lands ;

39. to immigration or naturalization : to the Committee on Immigration and Naturalization ;

40. to ventilation and acoustics : to the Committee on Ventilation and Acoustics.

41. The examination of the accounts and expenditures of the several Departments of the Government and the manner of keeping the same ; the economy, justness, and correctness of such expenditures ; their conformity with appropriation laws; the proper application of public moneys; the security of the Government against unjust and extravagant demands; retrenchment; the enforcement of the payment of moneys due to the United States; the economy and accountability of public officers; the abolishment of useless offices; the reduction or increase of the pay of officers, shall all be subjects within the jurisdiction of the eight standing committees on the public expenditures, in the several Departments, as follows: 
42. In the Department of State : to the Committee on Expenditures in the State Department;

43. In the Treasury Department: to the Committee on Expenditures in the Treasury Department ;

44. In the War Department: to the Committee on Expenditures in the War Department ;

45. In the Navy Department : to the Committee on Expenditures in the Navy Department ;

46. In the Post-Office Department : to the Committee on Expenditures in the Post-Office Department ;

47. In the Interior Department; to the Committee on Expenditures in the Interior Department ;

48. In the Department of Justice : to the Committee on Expenditures in the Department of Justice ;

49. In the Department of Agriculture: to the Committee on Expenditures in the Department of Agriculture ;

50. On public buildings : to the Committee on Expenditures on Public Buildings ;

51. All proposed action touching the rules and joint rules and order of business shall be referred to the Committee on Rules;

52. Touching the expenditure of the contingent fund of the House, the auditing and settling of all accounts which may be charged therein by order of the House : to the Committee on Accounts ;

53. The ascertainment of the travel of members of the House shall be made by the Committee on Mileage and reported to the Sergeant-at-Arms ;

54. Touching the Library of Congress, statuary, and pictures : to the Joint Committee on the Library ;

55. All proposcd legislation or orders touching printing shall be referred to the Joint Committee on Printing on the part of the House ;

56. The enrollment of engrossed bills : to the Joint Committee on Enrolled Bills.

57. The following-named committees shall have leave to report at any time on the matters herein stated, viz. : The Committee on Rules, on rules, joint rules, and order of business; the Committee on Elections, on the right of a Member to his seat ; the Committee on Ways and Means, on bills raising revenue; the committees having jurisdiction of appropriations, the general appropriation bills; the Com- 
mittee on Rivers and Harbors, bills for the improvement of rivers and harbors; the Committee on Banking and Currency, bills relating to banking and currency ; the Committee on Coinage, Weights, and Measures, bills relating to coinage; the Committee on the Public Lands, bills for the forfeiture of land grants to railroads and other corporations, bills preventing speculation in the public lands, and bills for the reservation of the public lands for the benefit of actual and bona fide settlers; the Committee on Enrolled Bills, enrolled bills; the Committee on Printing, on all matters referred to them of printing for the use of the House or two Houses; the Committee on Accounts, on all matters of expenditure of the contingent fund of the House.

It shall always be in order to call up for consideration a report from the Committee on Rules, and pending the consideration thereof the Speaker may entertain one motion that the House adjourn; but after the result is announced, he shall not entertain any other dilatory motion until the said report shall have been fully disposed of."

58. No committee, except the Committee on Rules, ${ }^{4}$ shall sit during the sitting of the House without special leave.

59. It shall be the duty of the several committees having jurisdiction of the general appropriation bills to report said appropriation bills (except the general deficiency bill) within eighty days after the committees are announced in a long session, and within forty days after the commencement of a short session; and if any committee fail to so report, the reasons for such failure shall be privileged for consideration when called for by any member of the House.

\section{Rule XII.-Delegates.}

The Speaker shall appoint from among the Delegates one additional member on each of the following committees, viz: Coinage, Weights, and Measures ; Agriculture ; Military Affairs ; Post-Office and PostRoads; Public Lands; Indian Affairs; Private Land Claims; and Mines and Mining; and two on the Committee on the Territories; and they shall possess in their respective committees the same powers and privileges as in the House, and may make any motion except to reconsider.

This paragraph was inserted by the Fifty-third Congress.

- This clause was inserted by the Fifty-third Congress. 


\section{Rule XIII.-Calendars.}

1. There shall be three calendars of business reported from committees, viz. :

First. A Calendar of the Committee of the Whole House on the state of the Union; to which shall be referred bills raising revenue. general appropriation bills, and bills of a public character, directly or indirectly appropriating money or property :

Second. A House Calendar, to which shall be referred all bills of a public character not raising revenue nor directly or indirectly appropriating money or property; and

Third. A Calendar of the Committee of the Whole House, to which shall be referred all bills of a private character.

2. All reports of committees on private bills, ${ }^{5}$ together with the views of the minority, shall be delivered to the Clerk for printing and reference to the proper calendar under the direction of the Speaker in accordance with the foregoing clause, and the titles or subjects thereof shall be entered on the Journal and printed in the Record.

3. All bills reported adversely shall be laid on the table, unless the committee reporting the same at the time, or any Member within three days thereafter, shall request its reference to the Calendar, when it shall be referred as provided in clause one of this rule.

\section{Rule XIV.-Of Decorum and Debate.}

I. When any Member desires to speak or deliver any matter to the House, he shall rise and respectfully address himself to "Mr. Speaker," and, on being recognized, may address the House from any place on the floor or from the Clerk's desk, and shall confine himself to the question under debate, avoiding personality.

2. When two or more Members rise at once, the Speaker shall name the Member who is first to speak ; and no Member shall occupy more than one hour in debate on any question in the House or in the committee, except as further provided in this rule.

3. The Member reporting the measure under consideration from a committee may open and close, where general debate has been had thereon; and if it shall extend beyond one day, he shall be entitled to one hour to close, notwithstanding he may have used an hour in opening.

4. If any Member, in speaking, or otherwise, transgress the rules

such had long been the practice. 
of the House, the Speaker shall, or any Member may, call him to order; in which case he shall immediately sit down, unless permitted on motion of another Member to explain, and the House shall, if appealed to, decide on the case, without debate ; if the decision is in favor of the Member called to order, he shall be at liberty to proceed, but not otherwise; and, if the case require it, he shall be liable to censure or such punishment as the House may deem proper.

5. If a Member is called to order for words spoken in debate, the Member calling him to order shall indicate the words excepted to, and they shall be taken down in writing at the Clerk's desk and read aloud to the House; but he shall not be held to answer, nor be subject to the censure of the House therefor, if further debate or other business has intervened.

6. No Member shall speak more than once to the same question without leave of the House, unless he be the mover, proposer, or introducer of the matter pending, in which case he shall be permitted to speak in reply, but not until every Member choosing to speak shall have spoken.

7. While the Speaker is putting a question or addressing the House no Member shall walk out of or across the Hall, nor, when a Member is speaking, pass between him and the Chair; and during the session of the House no Member shall wear his hat, or remain by the Clerk's desk during the call of the roll or the counting of ballots, or smoke upon the floor of the House; neither shall any other person be allowed to smoke on the floor of the House at any time; and the Sergeant-at-Arms and Doorkeeper are charged with the strict enforcement of this clause.

\section{Rule XV.-On Calls of the Roll and House.}

I. Upon every roll call the names of the Members shall be called alphabetically by surname, except when two or more have the same surname, in which case the name of the State shall be added; and if there be two such Members from the same State, the whole name shall be called; and after the roll has been once called, the Clerk shall call in their alphabetical order the names of those not voting; and thereafter the Speaker shall not entertain a request to record a vote.

2. In the absence of a quorum, fifteen Members, including the Speaker, if there is one, shall be authorized to compel the attendance of absent Members, and in all calls of the House the names of the 
members shall be called by the Clerk, and the absentees noted; the doors shall then be closed, and those for whom no sufficient excuse is made may, by order of a majority of those present, be sent for and arrested, wherever they may be found, by officers to be appointed by the Sergeant-at-Arms for that purpose, and their attendance secured; and the House shall determine upon what condition they shall be discharged.

Members who voluntarily appear shall, unless the House otherwise direct, be immediately admitted to the Hall of the House, and they shall report their names to the Clerk to be entered upon the Journal as present.

\section{Rule XVI.-On Motions, their Precedence, etc.}

I. Every motion made to the House and entertained by the Speaker shall be reduced to writing on the demand of any Member, and shall be entered on the Journal with the name of the Member making it, unless it is withdrawn the same day.

2. When a motion has been made, the Speaker shall state it, or (if it be in writing) cause it to be read aloud by the Clerk before being debated, and it shall then be in possession of the House, but may be withdrawn at any time before a decision or amendment.

3. When any motion or proposition is made, the question, Will the House now consider it? shall not be put unless demanded by a Member. ${ }^{\circ}$

4. When a question is under debate no motion shall be received but to fix the day to which the House shall adjourn, ${ }^{7}$ to adjourn, to take a recess, ${ }^{\circ}$ to lay on the table, for the previous question (which motions shall be decided without debate), to postpone to a day certain, to refer or amend, or to postpone indefinitely, which several motions shall have precedence in the foregoing order $;^{\bullet}$ and no motion to postpone to a day certain, to refer, or to postpone indefinitely, being decided, shall be again allowed on the same day at the same stage of the question.

5. A motion to fix the day to which the House shall adjourn, a mo-

- Originally, "or is deemed necessary by the Speaker."

Tomitted in the rules of the Fifty-first Congress.

- Omitted in the rules of the Fifty-first Congress.

- March 13, 1882, these motions were classed as above and were declared for the first time to have precedence according to their order; previously the Speaker had usually decided as to their precedence. 
tion to adjourn, and to take a recess shall always be in order, and the hour at which the House adjourns shall be entered on the Journal.

6. On the demand of any Member, before the question is put, a question shall be divided if it include propositions so distinct in substance that one being taken away a substantive proposition shall remain.

7. A motion to strike out and insert is indivisible, but a motion to strike out being lost shall neither preclude amendment nor motion to strike out and insert ; and no motion or proposition on a subject different from that under consideration shall be admitted under color of amendment.

8. Pending a motion to suspend the rules the Speaker may entertain one motion that the House adjourn ; but after the result thereon is announced he shall not entertain any other dilatory motion till the vote is taken on suspension.

9. At any time after the expiration of the morning hour it shall be in order to move that the House resolve itself into the Committee of the Whole House on the state of the Union for the purpose of considering bilis raising revenue, or general appropriation bills.

\section{Rule XVII.-Previous Question.}

r. There shall be a motion for the previous question, which, being ordered by a majority of Members present, if a quorum, shall have the effect to cut. off all debate and bring the House to a direct vote upon the immediate question or questions on which it has been asked and ordered. Provided that when the previous question is ordered on any proposition on which there has been no debate, it shall be in order to debate the proposition to be voted on for thirty minutes, onehalf of such time to be given to debate in favor of, and one-half to debate in opposition to such proposition. The previous question may be asked and ordered upon a single motion, a series of motions allowable under the rules, or an amendment or amendments, or may be made to embrace all authorized motions or amendments and include the bill to its passage or rejection. It shall be in order, pending the motion for or after the previous question shall have been ordered on its passage, for the Speaker to entertain and submit a motion to commit, with or without instructions, to a standing or select committee ; and a motion to lay upon the table shall be in order on the second and third reading of a bill. 
2. A call of the House shall not be in order after the previous question is ordered, unless it shall appear upon an actual count by the Speaker that a quorum is not present.

3. All incidental questions of order arising after a motion is made for the previous question and pending such motion shall be decided, whether on appeal or otherwise, without debate.

\section{Rule XVIII.-Reconsideration.}

I. When a motion has been made and carried or lost, it shall be in order for any Member of the majority, on the same or succeeding day, to move for the reconsideration thereof, and such motion shall take precedence of all other questions except the consideration of the conference report, a motion to fix the day to which the House shall adjourn, to adjourn, or to take a recess, and shall not be withdrawn after the said succeeding day without the consent of the House, and thereafter any Member may call it up for consideration : Provided, That such motion, if made during the last six days of a session, shall be disposed of when made.

2. No bill, petition, memorial, or resolution referred to a committee, or reported therefrom for printing and recommitment, shall be brought back into the House on a motion to reconsider ; and all bills, petitions, memorials, or resolutions reported from a committee shall be accompanied by reports in writing, which shall be printed.

\section{Rule XIX.-Of Amendments.}

When a motion or proposition is under consideration, a motion to amend and a motion to amend that amendment shall be in order, and it shall also be in order to offer a further amendment by way of substitute, to which one amendment may be offered, but which shall not be voted on until the original matter is perfected, but either may be withdrawn before amendment or decision is had thereon. Amendments to the title of a bill or resolution shall not be in order until after its passage, and shall be decided without debate.

\section{Rule XX.-Of Amendments of the Senate.}

Any amendment of the Senate to any House bill shall be subject to the point of order that it shall first be considered in the Committee of the Whole House on the state of the Union if, originating in the House, it would be subject to that point. 


\section{Rule XXI.-On Bills.}

I. Bills and joint resolutions on their passage shall be read the first time by title and the second time in full, when, if the previous question is ordered, the Speaker shall state the question to be : Shall the bill be engrossed and read a third time? and if decided in the affirmative, it shall be read the third time by title, unless the reading in full is demanded by a Member, and the question shall then be put upon its passage.

2. No appropriation shall be reported in any general appropriation bill, or be in order as an amendment thereto, for any expenditure not previously authorized by law, unless in continuation of appropriations for such public works and objects as are already in progress. Nor shall any provision in any such bill or amendment thereto changing existing law be in order, except such as, being germane to the subjectmatter of the bill, shall retrench expenditures by the reduction of the number and salary of the officers of the United States, by the reduction of the compensation of any person paid out of the Treasury of the United States, or by the reduction of amounts of money covered by the bill: Provided, That it shall be in order further to amend such bill upon the report of the committee or any joint commission authorized by law or the House members of any such commission having jurisdiction of the subject-matter of such amendment, which amendment, being germane to the subject-matter of the bill, shall retrench expenditures.

3. All bills for improvement of rivers and harbors, and all bills of a private nature, shall be delivered to the Clerk, as in the case of memorials and petitions, for reference to appropriate committees.

4. No bill for the payment or adjudication of any private claim against the Government shall be referred, except by unanimous consent, to any other than the following-named committees, viz: To the Committee on Invalid Pensions, to the Committee on Pensions, to the Committee on Claims, to the Committee on War Claims, to the Committee on Private Land Claims, and to the Committee on Accounts.

\section{Rule XXII.-Of Petitions, Memorials, Bills, and Resolutions.}

1. Members having petitions or memorials or bills of a private nature to present may deliver them to the Clerk, indorsing their 
names and the reference or disposition to be made thereof; ${ }^{10}$ and said petitions and memorials and bills of a 'private' nature, except such as, in the judgment of the Speaker, are of an obscene or insulting character, shall be entered on the Journal with the names of the Members presenting them, and the Clerk shall furnish a transcript of such entry to the official reporters of debates for publication in the Record.

2. Any petition or memorial or private bill excluded under this rule shall be returned to the Member from whom it was received; and petitions and private bills which have been inappropriately referred may, by direction of the committee having possession of the same, be properly referred in the manner originally presented; and an erroneous reference of a petition or private bill under this clause shall not confer jurisdiction upon the committee to consider or report the same.

3. All other bills, memorials, and resolutions may in like manner be delivered, indorsed with the names of members introducing them, to the Speaker, to be by him referred, ${ }^{2}$ and the titles and reference thereof, and of all bills, resolutions, and documents referred under the rules, shall be entered on the Journal and printed in the Record of the next day, and correction in case of error of reference may be made by the House, without debate, ${ }^{12}$ and in accordance with Rule $\mathrm{XI}$, on any day immediately after the reading of the Journal, by unanimous consent, or on motion of a committee claiming jurisdiction, or on the report of the committee to which the bill has been erroneously referred.

4. When a bill, resolution, or memorial is introduced "by request," these words shall be entered upon the Journal and printed in the Record.

5. All resolutions of inquiry addressed to the heads of Executive Departments shall be reported to the House within one week after presentation.

10 Thus members may send private bills to what committees they please, provided only that they keep within the rules. See ruling on this, Cong. Record, 53 Cong. $x$ Sess., 1896 .

11 The rules of the Fiftieth Congress made the change which freed the Speaker from the necessity of making the reference openly in the House.

12 This clause was inserted by the Fifty-third Congress. 


\section{Rule XXIII.-Of Committees of the Whole House.}

I. In all cases, in forming a Committee of the Whole House, the Speaker shall leave his chair after appointing a chairman to preside, who shall in case of disturbance or disorderly conduct in the galleries or lobby, have power to cause the same to be cleared.

2. Whenever a Committee of the Whole House finds itself without a quorum, the chairman shall cause the roll to be called, and thereupon the committee shall rise, and the chairman shall report the names of the absentees to the House, which shall be entered on the Journal; but if on such call a quorum shall appear, the committee shall thereupon resume its sitting without further order of the House.

3. All motions or propositions involving a tax or charge upon the people; all proceedings touching appropriations of money, or bills making appropriations of money or property, or requiring such appropriation to be made, or authorizing payments out of appropriations already made, or releasing any liability to the United States for money or property, shall be first considered in a Committee of the Whole, and a point of order under this rule shall be good at any time before the consideration of a bill has commenced.

4. In Committees of the Whole House, business on their calendars shall be taken up in regular order, except bills for raising revenue, general appropriation bills, and bills for the improvement of rivers and harbors, which shall have precedence, and when objection is made to passing over any bill or proposition, the committee shall thereupon rise and report such objection to the House, which shall decide, without debate, whether such bill or proposition shall be considered or laid aside for the present ; whereupon the committee shall resume its sitting without further order of the House.

5. When general debate is closed by order of the House, any Member shall be allowed five minutes to explain any amendment he may offer, after which the Member who shall first obtain the floor shall be allowed to speak five minutes in opposition to it, and there shall be no further debate thereon; but the same privilege of debate shall be allowed in favor of and against any amendment that may be offered to an amendment; and neither an amendment nor an amendment to an amendment shall be withdrawn by the mover thereof unless by the unanimous consent of the committee.

6. The committee may, by the vote of a majority of the Members present, at any time after the five minutes' debate has begun upon 
proposed amendments to any section or paragraph to a bill, close all debate upon such section or paragraph, or, at its election, upon the pending amendments only (which motion shall be decided without debate); but this shall not preclude further amendment, to be decided without debate.

7. A motion to strike out the enacting words of a bill shall have precedence of a motion to amend ; and, if carried, shall be considered equivalent to its rejection. Whenever a bill is reported from a Committee of the Whole with an adverse recommendation, and such recommendation is disagreed to by the House, the bill shall stand recommitted to the said committee without further action by the House. But before the question of concurrence is submitted, it is in order to entertain a motion to refer the bill to any committee, with or without instructions, and when the same is again reported to the House it shall be referred to the Committee of the Whole without debate.

8. The rules of proceeding in the House shall be observed in Committees of the Whole House so far as they may be applicable. ${ }^{13}$

\section{Rule XXIV.-Order of Business. ${ }^{14}$}

I. After the Journal is read and approved each day, the Speaker shall lay before the House, for reference, without debate, messages from the President, reports and communications from the heads of Departments, and other communications addressed to the House, and also such bills, resolutions, and other messages from the Senate as may have been received on previous days, but no such message, report, communication, bill, or resolution shall be printed except by order of the Speaker or the House; and House bills with Senate amendments which do not require consideration in Committee of the Whole may be at once disposed of as the House may determine.

2. On all days other than the first and third Mondays in each month as soon as the business on the Speaker's table has been disposed of, there shall be a morning hour for reports from committees, whicb shall be appropriately referred and printed, and a copy thereof mailed by the Public Printer to each Member and Delegate, if requested in writing by the Member or Delegate; and the Speaker shall call upon

${ }^{13}$ December 29, 1817 , the following rule was adopted: "Not more than three bills originating in the House shall be committed to the same Committee of the Whole, and such bills shall be analogous in their nature, which analogy shall be determined by the Speaker."

${ }^{34}$ There are several changes in this rule which were made by the Fiftysecond Congress. 
each standing committee in regular order and then upon the select committees; and if the whole of the hour is not consumed by this call, then it shall be in order to proceed to the consideration of other business as hereinafter provided; but if he shall not complete the call within the hour, he shall resume it in the succeeding morning hour where he left off.

3. The morning hour for the call of committees shall not be dispensed with except by a vote of two-thirds of those present and voting thereon.

4. After the morning hour shall have been devoted to reports from committees (or the call completed), the Speaker shall again call the committees in regular order for one hour, upon which call each committee, on being named, shall have the right to call up for consideration any bill reported by it on a previous day. And whenever any committee shall have occupied the said hour for one day, it shall not be in order for such committee to designate any other proposition for consideration until all the other committees shall have been called in their turn; and when any proposition shall have occupied two hours on this call it shall thereafter remain on the Calendar as unfinished business and be taken up.in its order : Provided, That when the hour herein prescribed shall expire while the Committee of the Whole House on the state of the Union is considering a bill, the said committee shall rise without motion therefor.

5. After the hour under the preceding clause shall have been occupied, it shall be in order to proceed to the consideration of the unfinished busineșs in which the House may have been engaged at an adjournment, and at the same time each day thereafter, other than the first and third Mondays, until disposed of ; and it shall be in order to proceed to the consideration of all other unfinished business whenever the class of business to which it belongs shall be in order.

6. Unfinished business, if any, having been disposed of, motions shall be in order as follows :

First. That the House resolve itself into the Committee of the Whole House on the state of the Union to consider, first, bills raising revenue and general appropriation bills, and then other business on its Calendar.

Second. To proceed to the consideration of business on the House Calendar.

Third. On Friday of each week, after the morning hour, it shall be in order to entertain a motion that the House resolve itself into 
the Committee of the Whole House to consider business on the Private Calendar; and if this motion fail, then public business shall be in order as on other days.

\section{Rule XXV.-Priority of Business.}

All questions relating to the priority of business shall be decided by a majority without debate.

\section{Rule XXVI.-Private and District of Columbia Business.}

I. Friday in every week shall be set apart for the consideration of private business, unless otherwise determined by the House.

2. The second and fourth Mondays in each month shall, when claimed by the Committee on the District of Columbia, be set apart for the consideration of such business as may be presented by said committee.

3. The House shall, on each Friday, at $50^{\prime}$ clock p. m., take a recess until 8 o'clock, which evening session shall be devoted to the consideration of private bills reported from the Committee on Pensions, and the Committee on Invalid Pensions, to bills for the removal of political disabilities, and bills removing charges of desertion only ; said evening session not to extend beyond to o'clock and 30 minutes.

\section{Rule XXVII.-Unfinished Business of the Session.}

All business before committees of the House at the end of one session shall be resumed at the commencement of the next session of the same Congress in the same manner as if no adjournment had taken place.

\section{Rule XXVIII.-Change or Suspension of Rules.}

r. No rule shall be suspended except by a vote of two-thirds of the Members present, nor shall the Speaker entertain a motion to suspend the rules except on the first and third Mondays of each month, preference being given on the first Monday to individuals and on the third Monday to committees, and during the last six days of a session.

2. All motions to suspend the rules shall, before being submitted to the House, be seconded by a majority, by tellers, if demanded.

3. When a motion to suspend the rules has been seconded, it shall be in order, before the final vote is taken thereon, to debate the proposition to be voted upon for thirty minutes, one-half of such time to 
be given to debate in favor of, and one-half to debate in opposition to such proposition.

\section{Rule XXIX.-Conference Reports.}

The presentation of reports of committees of conference shall always be in order, except when the Journal is being read, while the roll is being called, or the House is dividing on any proposition. And there shall accompany every such report a detailed statement sufficiently explicit to inform the House what effect such amendments or propositions will have upon the measures to which they relate.

\section{Rule XXX.-Secret Session.}

Whenever confidential communications are received from the President of the United States, or whenever the Speaker or any Member shall inform the House that he has communications which he believes ought to be kept secret for the present, the House shall be cleared of all persons except the Members and officers thereof, and so continue during the reading of such communications, the debates and proceedings thereon, unless otherwise ordered by the House.

\section{Rule XXXI.-Reading of Papers.}

When the reading of a paper other than one upon which the House is called to give a final vote is demanded, and the same is objected to by any Member, it shall be determined without debate by a vote of the House.

\section{Rule XXXI1.-Drawing of Seats.}

I. At the commencement of each Congress, immediately after the Members and Delegates are sworn in, the Clerk shall place in a box, prepared for that purpose, a number of small balls of marble or other material equal to the number of Members and Delegates, which balls shall be consecutively numbered and thoroughly intermingled, and at such hour as shall be fixed by the House for that purpose, by the hands of a page, draw said balls one by one from the box and announce the number as it is drawn, upon which announcement the Member or Delegate whose name on a numbered alphabetical list shall correspond with the number on the ball shall advance and choose his seat for the term for which he is elected.

2. Before said drawing shall commence each seat shall be vacated 
and so remain until selected under this rule, and! any seat häving been selected shall be deemed forfeited if left unoccupled before the call of the roll is finished, and whenever the seats of Members and Delegates shall have been drawn, no proposition for a second draw. ing shall be in order during that Congress.

\section{Rule XXXIII.- Hall of the House.}

The Hall of the House shall be used only for the legislative business of the House, and for the caucus meetings of its members; except upon occasions where the House by resolution' agree to take part in any ceremonies to be observed therein ; and the Speaker shall not entertain a motion for the suspension of this rule.

\section{Rule XXXIV. - Of Admission to the Floor.}

The persons hereinafter named, and none other, shall be admitted to the Hall of the House, or rooms leading thereto, viz. : The President and Vice-President of the United States and their private secretaries, judges of the Supreme Court, members of Congress and members-elect, contestants in election cases during the pendency of their cases in the House, the Secretary and Sergeant-at-Arms of the Senate, heads of. Departments, foreign ministers, governors of States, the Architect of the Capitol, the Librarian of Congress and his assistant in charge of the Law Library, the Secretary of the Smithsonian In'stitution, such persons as have, by name, received the thanks of Congress, ex-memibers of the House of Representatives who are not interested either as party, agent, or attorney in' any claim or bill pending before Congress, and clerks of committees, when business from their committee is under consideration; and it shall not 'be 'in' order for the Speaker to entertain a request for the suspension of this rule or to present from the chair the request of any Member for unanimous consent.

\section{Rule XXXV. - Of Admission to the Galleries.}

The Speaker shall set aside a portion of the west gallery for the use of the President of the United States, the members of his Cabinet, justices of the Supreme Court, foreign ministers and suites; and the members of their respective families and shall also set aside another portion of the same gallery for the accommodation of persons to be admitted on the card of Members. The southerly half of the east gallery shall be assigned exclusively for the use of the fami- 
lies of members of Congress, in which the Speaker shall control one bench, and on request of a Member the Speaker shall issue a card of admission to his family, which shall include their visitors, and no other person shall be admitted to this section.

\section{Rule XXXVI.-Official and Other Reporters.}

I. The appointment and removal, for cause, of the official reporters of the House, including stenographers of committees, and the manner of the execution of their duties, shall be vested in the Speaker.

2. Stenographers and reporters, other than the official reporters of the House, wishing to take down the debates and proceedings, may be admitted by the Speaker to the reporters' gallery over the Speaker's chair, and to the ball in the rear thereof, under such regulations as he may, from time to time, prescribe; and he may assign seats on the floor to a representative of both the Associated and the United Press associations, and may admit to the privileges of the floor an assistant to each of such representatives. ${ }^{26}$

\section{Rule XXXVII.-Pay of Witnesses.}

The rule for paying witnesses subpœnaed to appear before the House, or either of its committees, shall be as follows : For each day a witness shall attend, the sum of two dollars; for each mile he shall travel in coming to or going from the place of examination, the sum of five cents each way; but nothing shall be paid for traveling when the witness has been summoned at the place of trial.

\section{Rule XXXVIII.-Papers.}

1. The clerks of the several committees of the House shall, within three days after the final adjournment of a Congress. deliver to the Clerk of the House all bills, joint resolutions, petitions, and other papers referred to the committee, together with all evidence taken by such committee under the order of the House during the said Congress, and not reported to the House ; and in the event of the failure or neglect of any clerk of a committee to comply with this rule, the Clerk of the House shall, within three days thereafter, take into his keeping all such papers and testimony.

10 This clause was inserted by the Fifty-second Congress. 


\section{Rule XXXIX.-Withdrawal of Papers.}

No memorial or other paper presented to the House shall be withdrawn from its files without its leave, and if withdrawn therefrom, certified copies thereof shall be left in the office of the Clerk; but when an act may pass for the settlement of a claim, the Clerk is authorized to transmit to the officer charged with the settlement thereof the papers on file in his office relating to such claim, or may loan temporarily to any officer or Bureau of the Executive Departments any papers on file in his office relating to any matter pending before such officer or Bureau, taking proper receipt therefor.

\section{Rule XL.-Ballot.}

In all other cases of ballot than for committees, a majority of the votes given shall be necessary to an election, and where there shall not be such a majority on the first ballot, the ballots shall be repeated until a majority be obtained; and in all balloting blanks shall be rejected and not taken into the count in enumeration of votes or reported by the tellers.

\section{Rule XLI.-Messages.}

Messages received from the Senate and the President of the United States, giving notice of bills passed or approved, shall be entered in the Journal and published in the Record of that day's proceedings.

\section{Rule XLII.-Executive Communications.}

Estimates of appropriations, and all other communications from the Executive Departments, intended for the consideration of any committees of the House, shall be addressed to the Speaker, and by him submitted to the House for reference. ${ }^{18}$

\section{Rule XLIII.-Qualifications of Officers and Employés.}

No person shall be an officer of the House, or continue in its employment, who shall be an agent for the prosecution of any claim against the Government, or be interested in such claim otherwise than as an original claimant; and it shall be the duty of the Committee on Accounts to inquire into and report to the House any violation of this rule.

16 In the Fifty-first Congress this clause read, "and by him referred as provided by clause 3 of Rule XXIV." 


\section{Rule XLIV.-Jefferson's Manual.}

The rules of parliamentary practice comprised in Jefferson's Manual shall govern the House in all cases to which they are applicable and in which they are not inconsistent with the standing rules and orders of the House and joint rules of the Senate and House of Representatives.

\section{Rule XLV.-As to Printing Bills.}

There shall be printed 500 copies of each bill of a public nature, of which 25 shall be deposited in the office of the Clerk of the House, roo copies shall be delivered to the Senate document room, and the remainder shall be deposited in the document room of the House for the use of Members; and there shall be printed roo copies of each private bill and bills relating to rivers and harbors, of which 25 copies shall be delivered to the Senate document room, and the remainder shall be deposited in the document room of the House for the use of Members. Motions to print additional numbers of any bill, report, resolution, or other public document shall be referred to the Committee on Printing; and the report of the committee thereon shall be accompanied by an estimate of the probable cost thereof. Unless ordered by the House no bill, resolution, or other proposition reported by a committee shall be reprinted unless the same be placed upon the Calendar.

\section{JOINT RULES OF THE TWO HOUSES REFERRING} TO THE SPEAKER.

After examination and report each bill shall be signed first by the Speaker of the House of Representatives, then by the President of the Senate.

At a joint meeting of the two Houses the President of the Senate takes the Speaker's chair and the Speaker sits upon his left. 


\section{APPENDIX E.}

\section{EXTRACTS FROM THE STATUTES AT LARGE RELATING TO THE SPEAKER.}

June I, 1789. At the first session of Congress after every general election of representatives, the oath of office aforesaid, shall be administered by any one member of the House of Representatives to the Speaker, and by him to all the members present, and to the Clerk, previous to entering on any other business; and to the members who afterward appear, previous to their taking their seats. Statutes at Large, I, 23 ; Revised Statutes, $§ 30$.

May 3, r798. The President of the Senate, the Speaker of the House of Representatives, or . . . shall be empowered to administer oaths or affirmations to witnesses, in any case under their examination. Statutes at Large, I, 554 ; Revised Statutes, § Ior.

January 22, 1818; July 28, 1866. The salary and accounts for travelling expenses in going to and returning from Congress . . . of Representatives and Delegates shall be certified by the Speaker of the House of Representatives. Statutes at Large, XIV, $323 ; \mathrm{Re}$ vised Statutes, § 47 .

August 1o, 1846. The regents [of the Smithsonian Institution] . . . shall be appointed as follows : . . the members of the House by the Speaker thereof. . . . Statutes at Large, IX, 103 ; Revised Statutes, $\$ 558 \mathrm{r}$.

August 22, 1852. A committee consisting of three members of the Senate and three members of the House of Representatives, shall be appointed by the President of the Senate and the Speaker of the House of Representatives, to be called the Joint Committee on the Public Printing. Statutes at Large, X, 34 ; Revised Statutes, $\$ 3756$.

August 16,1856 . . . . and the Speaker of the House of Representatives shall receive double the compensation above provided for representatives [\$3000]. Statutes at Large, XI, 48.

January 24, 1857. When a witness shall fail to testify . . . and the facts shall be reported to the House, it shall be the duty of the Speaker of the House . . . to certify the fact under the seal of the House to the district attorney for the District of Columbia. . . Statutes at Large, XI, 156 ; Revised Statutes, § ro4. 
March 3, 1863. Before the first meeting of [each Congress] the Clerk of the next preceding House of Representatives shall make a roll of the representatives elect, and place thereon the names of all persons and of such persons only whose credentials show that they were regularly elected in accordance with the laws of their States respectively; or the laws of the United States. Statutes at Large, XII, 804; Revised Statutes; § 31 .

July 28, 1866: . . . That the pay of the Speaker shall be eight thousand dollars per aninum. Staitutes at Large, XIV, 323.

July 27, 1868. . . . There shall be three other directors [of the Columbia Institution for the Instruction of the Deaf and Dumb] appointed in' the following manner: One Senator by the President of the Senate, and two Representatives by the Speaker of the House: Staitutes at Large, XV,-253; Revised Statutes, \$ 4863 .

Februariry 27; 1870. . . . In addition to the other members of the board of visitors [to attend the annual examination of the Academy at West Point] . . . there shall be on every such board. . . three members of the House of Representatives to be designated by the Spéaker. Statutes' at Large, XVI, 67 ; Revised Statutes, $§ 1327$.

April 2, 1872: No person shall be employed as a reporter of the House without the approval of the Speaker. . . . Statutes at Large, XVII, 47 ; Revised Statutes, $\$ 54$.

June 10, 1872. . . . There shall be three other directors [of the Columbia Hospital] appointed in the following manner : one Senator by the President of the Senate, and two Representatives by the Speaker of the House. . . . Statutes at Large, XVII, 360 .

May 3i 1876: Two consulting trustees [of the Reform School] shall be appointed; namely, one Senator of the United States by the presiding officer of the Senate, for the term of four years; and one member of the House of Representatives, by the Speaker thereof; for the term of two years. Stafutes at Laige, XIX, 52 .

February 14, 1879. There shall be appointed every year in the following manner, a Board of Visitors, to attend the annual examination of the: [naval] academy [at Annapolis] : Seven persons shall- be appointed by the President, and two Senators and three members of the House of Representatives shall be designated as Visitors by the Vice-President or President pro tem. of the Senate and the Speaker of the House of Representatives, respectively, at the session of Congress next preceding such examination. Statutes at Large, XX, 290: 


\section{APPENDIX F.}

\section{LIST OF REFERENCES TO VOTES CAST BY THE SPEAKER. ${ }^{1}$}

1. Casting-votes. House Journal, I Cong. I Sess., I60; 2 Cong. I Sess., 14I, ${ }^{2} 2$ Sess., 94, 97 ; 3 Cong. 2 Sess., 46 ; 5 Cong. 2 Sess., 55. 625 ; 6 Cong. 2 Sess., 42, II4 ; 7 Cong. I Sess., 304, 2 Sess., 40, II 7, 262, 337 ; 8 Cong. I Sess., 35, 153; 9 Cong. 2 Sess., I I9, 287, 342 ; 10 Cong. 2 Sess., 445 ; i I Cong. I Sess., 329, 2 Sess., 467 ; 12 Cong. I Sess., 795, 833, 2 Sess., 78 ; r3. Cong. I Sess., 63, 132, 3 Sess., 464, 629, 639 ;' 14 Cong. 2 Sess., 325 ; 15 Cong. 2 Sess., 290; 16 Cong. 2 Sess., 257 ; 18 Cong. I Sess., 405 ; 20 Cong. 2 Sess., 252, 357-8; 21 Cong. I Sess., 707, $710,721,2$ Sess., 351 ; 22 Cong. I Sess., 315, 479, 904, 970; 23 Cong. I Sess., 616; 24 Cong. I Sess., 226, 395, 782, 966, 972, $1160 ; 25$ Cong. I Sess., 147, 2 Sess., 355, 840-I, 88S, I115, 1228, 3 Sess., 179, 323 ; 26 Cong. I Sess., 826, 1123 ; 27 Cong. 2 Sess., 52, III, 1382, ${ }^{2}$ 1645, 3 Sess., 93. $451 ; 28$ Cong. I Sess., 67, 620, 2 Sess., 169, 383 ; 29 Cong. I Sess., 482, 526, 851, 1057, 1085; 31 Cong. I Sess., 84I, I373; 32 Cong. I Sess. 738, 1129; 34 Cong. I Sess., 562, 602, 750, 999, 1231, 1436, 1503; 37 Cong. 2 Sess., 383, $399 ; 48$ Cong. I Sess., II 29.

2. Votes cast with the minority to make an even division. House Journal, 2 Cong. I Sess., I9I, 2 Sess., 60 ; 6 Cong. 2 Sess., I9I-2, 808-9 ; Io Cong. 2 Sess., 449 ; II Cong. I Sess., 58, 247, 2 Sess., 305; 12 Cong. I Sess., II5 ; I8 Cong. I Sess., 422, 520; 20 Cong. 2 Sess., 357-8 ; 25 Cong. 3 Sess., 308 ; 26 Cong. I Sess., 81 2 ; 29 Cong. I Sess., 1080; 30 Cong. I Sess., 1067; 31 Cong. I Sess., 221, 1058, 2 Sess., 167; 32 Cong. I Sess., 131; 33 Cong. 1 Sess., 506.

3. Votes cast with the majority to make a two-thirds vote. House Journal, 8 Cong. I Sess., I9I ; 28 Cong. I Sess., $445 ; 44$ Cong. 2 Sess., $24 ; 47$ Cong. I Sess., 1674-5.

4. Unnecessary votes cast. House Journal, 14 Cong. 2 Sess., 539 ; 18 Cong. 2 Sess., 7 I-74; 32 Cong. I Sess., 54I-2; 33 Cong. I Sess., 946-8 ; 34 Cong. I Sess., 499 ; 44 Cong. 2 Sess., 105.

1 This list is somewhat incomplete as regards the later Congresses, the in dices to the Journals of which do not include the Speaker's votes.

- Speaker roted in negative on an even division. See above, $89 \mathrm{r}$.

- This was the vote by which the National Bank was lost in 1815 . 


\section{N D E X.}

A DAMS, JOHN, on partiality of A President of Congress, 22, 23. Adams, John Quincy, in contested election of $1839,52,53$; elected President, 83 ; difficult to control in House, 87 ; defiance of Speaker, 126 n., 173 ; serves as Speaker pro tem., I43; disorderly conduct, I64, 165; refusal to vote, 184-86; loses chairmanship of committee on Foreign Relations, 224 ; consulted in regard to committees, 226 ; committee service, 226; urges Senate to follow President, 320; remarks on Jones, 46 ; on Stevenson, 64,65 ; on Bell, 86 ; on Hunter, 89; on Davis, 90 ; on Speakers pro tem., I4I ; on appointment of himself as chairman of Committee of Whole, r44; on appointment of himself as chairman of a committee, 229; on negotiations for a change of committee places, $23^{2}, 233$; on the construction of a special committee, 234,235 ; on the committee system, 240,241 ; on Speaker's rank, 296.

Abercrombie, Speaker of House of Commons, 29.

Adjournment, attempt of Speaker of Commons to force upon House, 7.

Aiken, candidate for Speakership in 1855, $5^{8}$.

American party, in contested election of $1855,59$.

Appeals, rare in House of Commons, 167; practice in House of Representatives, $167-69$; Speaker's right to refuse, 200-I I ; Reed refuses, I92-94; Colfax refuses, 210; Blaine refuses, 210; Keifer refuses, 210; question of appeals from recognition, 259,260 .

Banks, Nathaniel P., elected Speaker in 1855,58 ; qualifications for office, $36,58,59$; character of Speakership, 94 ; casts an unneces- sary vote, I53; quells disorder, 16r, r62; committee appointments, 227.

Barbour, Philip P., elected Speaker in 1821,51 ; character of Speakership, $\mathbf{8}_{3}, 86$.

Bell, John, elected Speaker in $\mathbf{1 8 3 4}$, 51, 86; character of Speakership, 86; candidate for Speakership in 1837 and in 1839,86 ; candidate for Presidency, 85,271 .

Benton, Thomas H., on Clay, 8I ; Wentworth's tactics to get the floor for, 257,258 ; on Speaker's precedence, 297.

Bills, Speaker refers, 299,300 .

Blaine, James G., popularity, 36 ; character of Speakership, I03, I04; committees, 104, 228 ; controversy with Butler, I04-7; Little Rock affair, I07-9; compared with Randall, I II, IIz; Crédit Mobilier scandal, 134; quorum decision, 188 , I89; ruling on dilatory motions, 208 and n.; refuses to receive appeals, 210; against early announcement of committees, 231 ; arbitrary use of recognition, 261 ; influence from chair, 282,283 ; inaugural speech, 288 ; speech from floor, 292; candidate for Presidency, 271 ; on Winthrop, $90,92$.

Boyd, Linn, character of Speakership, 93 : casts unnecessary votes, 153; submits amendment from chair, 290.

Brand, Speaker of House of Commons, stops obstruction in, in $1881,18 \mathrm{r}, 182$.

Brewer, Judge, decision on DingleyWorsted act, $2 I_{3}$.

Brown, Wm. J., candidate for Speakership in 1849,54 .

Business, order of, Speaker announces, I32; Speaker no control over, 132, 133; practice of House of Commons, 132; practice of European assemblies, $132 \mathrm{n}$. 
Butler, B. F., controversy with Blaine, 104-7; attempt to have a quorum counted, $188,189$.

Cabinet, President's, 325-30.

Cabinet system, English, 316, 31.7.

Carlisle, John G.. seat contested, 32 ; election of 1883 and 1887,34 , 39 ; popularity, 36 ; character of Speakęrșip, 115, 116, 273, 305 ; compared with Randall and Crisp, 120,121 ; accusation against, 131 ; decision on private bills, $175, \times 76$; interpretation of rules, $177 ;$ quorum decision, 204; committee appointments, 227, 220; minute hand of clock turned back, 254; arbitrary use of recognition, 26266 ; correspondence with Democratic members on recognition, $263-65$; inaugural speeches, 286 , 287 ; on refusal to vote, 201 ; on Speaker's power, 314.

Caucus, election of Speaker in, 40.

Censure, votes of, in House of Commons, $124 ;$ in House of Representatives, 124, 134.

Chair, influence from, 301 ; right of leaving, $290-92$; when customary to leave, 133-35.

Charles 1., search of five members, 8 .

Chaucer, Speaker of the House of Commons, $3 \mathrm{n}$.

Civil War, influence on Speakership, 96,97 .

Clay, Henry (see Contents, Chap. III.), election of $1811,34,69-71$; election of 1823,83 ; length of service, 35 ; qualifications for office, $69,70,71$; resignations of 1814 and 1820,50 : appointments, 38 , 226 ; manipulation of rules, 73,74 ; conference with President, 77; admiration for Clay's Speakership, 78, 79; tact and dignity, 8082 ; conception of Speaker's vote, $152,157,158$; leaves Senate to become Speaker, 270, 271 : refuses other positions, 272 ; sent to Ghent, 271 : term of $1823-24,183$; becomes Secretary of State in 1824,83 ; candidate for Presidency, 27I ; charges against, 28r n.; inaugural speech of 1823 , 284 ; Randolph's attack, 295; advice to Winthrop, 72.
Clerk, of House of Commons, presides till Speaker elected, 28 ; of House of Representatives, presides during election of Speaker, 41 ; makes up roll of members, 41 ; decision of, on precedence of Speaker's election, 42 ; declares Speaker duly elected, 43 .

Cleveland, President, understanding with Crisp. 329.

Closure, Speaker's contral of, in House of Commons, 182,$183 ;$ in European assemblies, 182 n.

Cobb, Howell, elected Speaker in 1849,53-56, 93; character of Speakership, 93; charged with mutilation of Journal, 130,134 ; letter in defence of a decision, 169 ; attempt to prevent Mr. Julian from speaking, 261; asks leave from floor to make explanation, 292 ; presides over Southern Congress, 271.

Colfax, Schuyler (see Contents, Chap. III.), popularity, 36,37, yor ; character of Speakership, 98-102 ; compared with Clay, 100-2; ignorance of parliamentary law, 37 : inaugural speeches, 285 ; opposes President Johnson, 99 ; engages in action of House, 99 , 100; personal characteristics, IO1, 102 ; quorum decision, 188 ; refuses an appeal, 210; decision on right of House to instruct committees, 243 n. ; announcement of committee on Rules, 274 ; becomes Vice-President, 271.

Colonial Speaker (see Contents, Chap. 1.), form of election, 30,31 ; retains a member's rights, 302, 303.

Cooke, struggle in Massachusetts General Court over election of, $13,14$.

Committees (see Contents, Chap. VIII.), appointment of, in colonies, 15 in Continental Congress, 21 ; in Constitutional Convention, $24 ;$ in House of Representatives, $300,304,305$; in House of Commons, $217 \mathrm{n}$. ; in European assemblies, $217 \mathrm{n}$. ; influence of prerogative on Speaker's election, 38, 39: importance of in contested election of 1849,54 ; in contested election of $1855,57-59$. 
Committee system, effects of, 3०3-: 306 ; effect of, on independence of Congress, 325 .

Committee on Claims, question of chairman of, 219, 220.

Committee on Rules, Speaker, chairman of, $273,274,277,278,300$, 305 ; Carlisle's and Reed's appointment of, II7; failure to report, x 6 ; report on rules of 1890,311 ; given power over obstruction, 214 ; power of, 274-80; proposals to change, $278-80$.

Committee of Ways and Means, creation of, 325 .

Committee of Whole, chairman of, House appoints in Pennsylvania Assembly, 15 ; practice of House of Commons, 137 ; in House of Representatives Speaker appoints, 136 , r37, 294, 299, 300, 305, 308 n. ; Speaker required to resume chair, r37-40; status of Speaker in, 292-94.

Commons, House of, obstruction in, $18 \mathrm{r}-83$; obliges members to vote, 194 ; quorum practice, 194 ; rules on debate, 182,183 ; appointment of committees, 217 n.; appointment of a deputy Speaker, I40 : Committee of Whole, chairman of Ways and Means presides, 137: disorder in Committee, 138,139 ; Speaker in Committee, 292, 293.

Commons, House of, Speaker of (see Contents, Chap. I.), election of, form of, 27, 28; a Cabinet appointment, 29 ; motives, 29.30 ; removal of Speaker, 123 ; censure of, 124; case of refusal to put question, 133; puts questions in which personally interested, 13335 ; influence over order of business, 132 ; a casting vote, $147, x_{48}$, 151, 152; reasons determining, r56, 157; statement of reasons, r59; preservation of order, 163 ; appeals from rare, 167 ; control of closure, 182,183 ; does not leave chair ordinarily, I40 n.; gives up rights as a member, 289,290 ; impartiality, 300; precedence, $296 \mathrm{n}$.

Compensation, 297-99.

Congress of Confederation, President of, 20-24.

Congress, Continental, President of, 20-24.
Congress of U. S., relation to Executive, 318-30.

Constitutional Convention, President of, 24, 25.

Constitution, Speakership clause in, 25,26 ; free election of Speaker, 31, 32 ; looseness of, 324 .

Council of State, proposed in Constitutional Convention, 25, 329, 330.

Courtney, Mr., Speaker of the House of Commons ; impartiality, 249.

Crisp, Charles F., elected Speaker in $1891,42,117-19$; character of Speakership, .120, 273, 311 ; compared with Reed and Carlisle, 120, 121 ; inaugural speech, 288 ; ruling on recognition, $25^{8}$; leaves chair to debate on rules, 278 ; understanding with Cleveland, 329.

Dana, Sam. W., forced to become chairman of Committee on Claims, 219, 220.

Davis, John W., character of Speakership, 90, 226.

Dayton, Jonathan, elected Speaker in 1795 and $1797,66,67$.

Debate, instance in colonies of Speaker's failure to control, 14,15 ; rules of House of Representatives, $16_{3}$, 164 ; rules of House of Commons, 182,183 .

Decisions (see Contents, Chap. VI., also below, questions of order), none of Clay's or Colfax'sreversed, 74, ror.

Departments, connection between, 326-30 ; need of better connection, $329,330$.

Deputies, Chamber of, President of, 315 : preservation of order, 163 .

Disorder, in House of Commons, r38, r39; in House of Representatives, I6r, 162 .

Dudley, Governor of Mass., struggle with General Court over election of Speaker, 13.

Election of Speaker in House of Commons, approval of King necessary, $3,4,5$, 10, $x_{1}$; case of a Speaker presented to Lords, 1647, 8 ; independent choice gained, II ; form of, 27, 28.

Election of Colonial Speaker, ap- 
proval of Governor necessary, 12 ; struggles for independent choice, 12-14; motives of, 15,16 ; form of, 30, 31 .

Election of President of Continental Congress, 2 r.

Election of President of Constitutional Convention, 24.

Election of Speaker of House of Representatives (see Contents, Chap. Il.), form of, 4I-44.

Elections, contested, of 1809,50 ; of I82O, 50, 51 ; of 1821,51 ; of 1825 , 51 ; of $1834,5^{1}$; of $1839,5^{1-53}$; of I849, $51,53-56$; of $1855,51,56-$ 60 ; of $1859,51,60-62$; of 1861,51 . Elections, plurality, $54-56,5^{8}$.

Eliot, Sir John, struggle with Speaker in Parliament of $1628,7$.

Elizabeth, Queen, dependence of Speakers under, 6.

Executive, relation to Congress, 326-3I.

Expulsion of Speaker, in colonies, 19,20 ; in House of Commons, 123, 124 ; in House of Representatives, 124 .

Federalist Speakers, 64-68.

Gallatin, Albert, influence over Congress, 224. 3 I9.

Garfield, James A., moved oath of office for Speaker pro tem., 44 ; on obstruction, 186,187 ; report from committee on Rules on recognition, $252,253$.

Giddings, Joshua R., in election of 1849,54 ; in election of 1855 , 56,57 ; in election of 1861,91 ; taken from committee on Territories, 226, 227.

Gouverneur, Mr., Speaker of New York Asseinbly, 20.

Governor, Colonial, approval necessary to Speaker's choice, I2; struggles with Speakers, I2-I4, 18, 19.

Graham, Mr., Speaker of New York Assembly, 20 .

Grant, President, letter to Speaker Blaine, 328.

Grow, Galusha A., candidate for Speakership in 1859,60 ; elected Speaker in $186 \mathrm{I}, 39,5 \mathrm{I}$; inaugural speech, $285 \mathrm{n}$.; character of Speakership, 97,98 ; speaks from floor, 98.
Hamilton, Alexander, influence over Speaker and Congress, 66 , $67,319$.

Hancock, John, President of Continental Congress, 23.

Hare, Speaker of the House of Commons, subserviency to Crown, 5 .

Hayes, R. B., election in House, IIO, III, 123 .

Hayes, W. T., candidate for nomination to the Speakership in 1891 , II9.

Helper's Impending Crisis, in election of $1855,6 \mathrm{r}$.

Henry, Patrick, Speaker's attempt to control, $\mathrm{r} 4$.

Hill, D. B., quorum decision in New York Senate, 201, 202.

Hoar, Sherman, refusal to vote for party nominee, 43 .

Hollis, Denzil, struggle with the Speaker in Parliament of 1628,7 .

House of Representatives, organization of, 4I-44; improvement in character of, $3 \mathrm{II}, 3 \mathrm{I2}$; inadequate connection with Senate, $329 \mathrm{n}$.

Hungerford, Sir Thomas, first Speaker of House of Commons, 3.

Hunter, R. M. T., elected Speaker in $1839,53,88$; character of Speakership, 89,90 ; interpretation of rules, 177 ; farewell speech, 89,90 , 225 n.; on committee responsibility, 225 n. ; candidate for Speakership in 1841,34 .

Jackson, Andrew, subserviency of Stevenson to, 84,85 ; dominates Congress, 323 .

Jay, John, President of Continental Congress, 22.

Jefferson, Thomas, dominates Congress, 68, 319, 320, 322, 323 .

Johnson, Andrew, opposition of Congress to, 102 .

Jones, John W., seat contested, 32, I34, 219; character of Speakership, 46, 90.

Julian, G. W., tactics to get floor, $26 r$.

Keifer, J. Warren, elected Speaker in I881, I I2, I13; in a u gural speech, 285, 285, 288 ; character of Speakership, I13, Ir4; committees, I 13 n., 238; asserts control of de- 
bate, 165,166 ; submits a decision to House, I70; refuses an appeal, 210; ruling on recognition, 259 ; remarks on recognition, 267 ; abandoned by party, $114,270$.

Kerr, M. C., long service, 34 ; elected Speaker in 1875,109 , Iro; character of Speakership, Iog.

Know-Nothings, in election of 1855 , 56.

Laurens, Henry, President of Continental Congress, 23.

Leadership, of colonial Speaker, I5, 16; of Speaker of House of Representatives, 33, 39, 293, 294, 301, 304-306, 310, 318, 319, 323-30 (see also Contents, Chap. X.).

Lee, Richard H., President of Continental Congress, 21.

Lefevre, Mr. Shaw, Speaker of the House of Commons, 30 .

Lenthall, reply to Charles I., 8.

Little Rock affair, 107-rog.

Long, expulsion moved by Speaker Colfax, $99,100$.

Lowndes, candidate for Speakership in 1820,51 .

Macon, Nathaniel, elected Speaker in 1801,1803 , and $1805,68,69$; character of Speakership, 68, 69; committees, 223 n., 320 ; votes on amendment to Constitution, 149 ; controlled by Jefferson, 322, 323 i candidate for Speakership in 1809 , $50,67$.

Madison, James, leader of First Congress, 319 ; remarks on Speaker's salary, 298; struggle with Clay, $70,77,78$.

Mansfield, Lord, on quorum, 203.

Margrave, Sir T., Speaker under Henry VIII., 6.

Mary, Queen, dependence of Speakers under, 6.

Massachusetts, General Court of, struggle with Governor over choice of Speaker, 13, I4.

Meinbers, roll of, made up by Clerk, 4I ; colonial Speaker retains rights as, 17 ; also Speaker of House of Representatives, 289-95, 301 ; denied to Speaker of House of Commons, 289, 290.

Mills, Roger L., candidate for Speakership nomination, 118 , 119.
Minority, Speakership nomination, 40, 41 ; abuse of power, $179-81$.

Monroe, James, struggle with Clay, 78,79 .

More, Sir Thomas, Speaker of House of Commons, 5 .

Mosely, Ed., Speaker of N. C. Assembly, I8.

Motions, dilatory, $180-83,187,191$, $193,207-12,214,215$.

Muhlenberg, Frederick A., elected Speaker in 1789 and $1793,65,66$; inaugural speech, 284 .

Mulligan letters, tumult over, 162.

New Jersey Assembly, 19.

New York Assembly, 17, 18, 20.

North Carolina Assembly, 18, 19.

Norton, Sir F., Speaker of the House of Commons, ro n., 12 n. ; on Speaker's part in Committee of Whole, 293.

Oakes, T., struggle of Massachusetts Court with Governor over election of, 13.

Oath, Speaker's, in House of Commons, 28 ; in House of Representatives, 44 .

Obstruction (see Contents, Chap. VII.)

Onslow, Speaker of House of Commons, ro $\mathrm{n}$.

Order (see Contents, Chap. VI.), in House of Commons, $163 ;$ in Chamber of Deputies, 163.

Order, Questions of (see Contents, Chap. VI.), decided by Clerk during Speaker's election, $4^{1}$; Committee of Whole may refer to Speaker, 139, 140 ; Speaker a casting vote on, 167,168 .

Orr, James L., character of Speakership, 94; committees, 226, 227 , 234 ; ruling on right of minority of a committee to report, 234 .

Palfrey, in election of $1847,91$.

Parliamentary duties (see Contents, Chap. IV.), 299, 300, 305, 306; opens and closes sittings of the House, 126; acts as mouthpiece and representative of the House, 127, 128 ; issues warrants, 128, 129 ; conducts judicial proceedings, 129 ; directs proceedings of House, 129; has charge of printing, 129 ; 
appoints employees of House, 129 ; appoints official reporters, 129 ; authenticates documents, 130 ; approves Journal, 130, 131; has control of petitions and memorials, $13 x$; approves sureties of Sergeant's bond, I3I ; certifies salaries and representatives, 131,132 ; announces order of business, 132 , 133 ; states the question, 133-36; announces votes, I36; appoints chairman of Committee of Whole, 136,137 ; required to resume chair when necessary, r37-40; appoints Speaker pro tem., 140-44; refers bills, etc., 144-46; sources of, 122, 123.

Patton, on Speaker's right to vote, 154, 155 ; offers amendment to give Speaker right of leaving chair, 29I.

Payson, Speaker pro tem., ruling on recognition, 257.

Peel, Sir R., appoints Speaker from opposite party in $\mathrm{x} 84 \mathrm{I}, 30$.

Pennington, Wm., elected Speaker in $1859,34,62,63,7 x, 94,95$; qualifications for office, 95 ; character of Speakership, 95; announcement of committee on Rules, 274.

Pennsylvania Assembly, I5-1 7 .

Philips, Adolphe, Speaker of N. Y. Assembly, 18.

Pitkin, Tim., candidate for Speaker in 1809,50 .

Pitt, on Speaker of 18 th century, II ; wishes to nominate Speaker, $27 \mathrm{n}$.

Political status of Speaker. (See Contents, Chap. XI.)

Polk, James K., elected Speaker in 1834 , in 1835 , and in $1837,34,86$; character of Speakership, 86, 87; difficulties of, 87,88 ; influence from chair, 28r; opposition to thanks to, 87 ; elected President in 1844, 271.

President, notified of Speaker's appointment, 49,50 ; early supremacy of, 319-23; relations of Speaker and, $321-30$.

Presidency, succession of Speaker to, 297.

Questions, Statement of, freedom of Speaker of House of Commons, 4 ; abuse of, in House of Commons, 9, 10; practice of House of Representatives, 134, 135 ; Speaker calls another member to chair when personally interested, $134-36,142,162$; contrary to practice of House of Commons, I33, 134 .

Questions of Order. (See Order.)

Question, Previous, 175.

Quorum, 180, 186-90, 192-207, 211$13,215,216 . \quad$ (See also Contents, Chap. VII.); practice of States, I97.

Randald, Samuel J., as chairman of a coinmittee, $262-7 x$; refuses to vote to make a quorum, 189 ; candidate for Speakership nomination in 1875 , 110 ; elected Speaker in 1876 ; 1 ro; inaugural speech, 285; character of Speakership, IIo, I12, 223 n. ; compared with Blaine, I I 1-1 12 ; decisions during Hayes' election in House, 1 ro, 111 , 122, 123 ; accusation against, $11 x$, 135 ; restores order in Committee of Whole, 139; casts an unnecessary vote, 153,154 ; ruling on dilatory motions, 208 ; influence from chair, 282 ; remarks on Speakership, $112,272,273$; on Crisp, 118 , I I9; on recognition, 250, 252, 255, $259-60,266,267$; on committee on Rules, 278.

Randolph, John, Macon's subserviency to, 69; conflicts with Speaker, 73, 74; Clay's tact in dealing with, 80 , $8 \mathrm{r}$ n.; address to constituents on ruling of Speaker, 168, 169; removed from Ways and Means, 224; language against Clay, 295 ; on relation of Clay and Madison, 78.

Randolph, Peyton, first President of Continental Congress, 2 r.

Rank, of Speaker of House of Commons, $296 \mathrm{n}$. ; of Speaker of House of Representatives, 296, 297.

Recognition (see Contents, Chap. IX., also 300, 301, 305) : practice of House of Com mons, 248, 249; practice of European assemblies, $248 \mathrm{n}$.; in State legislat ures, 250; Garfield's report from committee on Rules, 252, 253 ; how used by Blaine, ro3, 104, 26I, 262 ; by Carlisle, 262266; by Reed, 266. 
Reed, Thomas B., decision on dilatory motions in 1882,210 ; moves vote of thanks to Carlisle in r889, $46 \mathrm{n}$.; elected Speaker in 1889 , I 16 ; inaugural speech, 288, 289; character of Speakership, $116,117,239$, $267,273,305,307$; compared with Carlisle and Crisp, 120, 121 ; forbids personal controversy with chair, 125; accused of falsifying Journal, $\mathbf{r}_{3} \mathrm{r}$; action on obstruction, Igo-2 16 ; denies appeal from decisions on recognition, 262 ; use of recognition, 266; influence from chair, 281-83; farewell speech of I89r, 46, 47; moves thanks to Crisp in $1893,47,48$; refuses to vote upon thanks to Crisp in $\mathbf{1 8 9 5}$. 48 ; accounts for MclKinley tariff, 232 ; on right of Speaker to leave chair, $278 \mathrm{n}$.; on committee on Rules, 273.

Reëlections, 34, 35 .

Representation, English idea of, 302 ; colonial idea of, 302,303 .

Republican Speakers, 68, 69.

Respect due Speaker, 125, 126.

Responsibility, of colonial Speakers, I9, 20 ; of Speaker of House of Representatives, 123 , 124 ; for general question of, in House of Representatives, see Contents, Chap. XI.

Richard II., Speakers under, 3 n.

Rohinson, Geo. D., on dilatory motions, 209.

Robinson, John, Speaker of Virginia Assembly, ${ }_{5} \mathrm{n}$.

Sanford, J. E., quorum decision as Speaker of Massachusetts House of Representatives, zor.

Sedgwick, Theodore, elect ed Speaker in $1799,67,68$; character of Speakerslip, 67,68 ; struggle with reporters, 67,68 ; speech from chair, 68 ; vote of censure moved against, 124 ; party vote of thanks, 68.

Senate, notified of Speaker's appointment, 49, 50; method of appointing com mittees, 238 ; President of, 3 I9.

Seymour, Sir Ed., Speaker of House of Commons, 9 , ro; motion for removal, 123; Cliarles 11 . refuses to confirm election of, 10, II.
Sherman, candidate for Speakership in $1859,60-62,94$.

Shute, Governor, of Massachusetts, struggle with Court over election of Speaker, 13, 14.

Slade, struggle with Speaker Polk, 88.

Smith, Wm. L., leader of Federalists in House in $1797,66$.

Smith, Wm. N. H., candidate for Speakership in 1859,62 .

Speaker, origin of name, $127 \mathrm{n}$.

Speaker pro tem., appointment of, in Continental Congress, 21, 22 ; appointment of, in House of Representatives, 48-50, 140, 141, 299, 300,305 ; powers and authority, 5O, I4I, I42; Stevenson on Speaker's right to appoint. $\mathbf{1}_{42}$.

Speeches, inaugural, 284-89; farewell, 46,47 .

Springer, Wm. M., candidate for Speakership nomination in 1891 , Ir9; chairman of Ways and Means, 224.

States, jealousies of, 35,65 .

Stevens, ' $T$., leader on floor, $r 86 \mathrm{I}-63$, 98.

Stevenson, Andrew, length of service, 35 ; elected Speaker in $\mathbf{1 8 2 7}$, 84,323 ; inaugural speech, 284 . 285 ; character of Speakership, 64, $65,84,85$; vote of censure against, 124, I34; appointment of committees, 224, 232, 233; asserts right to appoint a temporary Speaker, 142; minister to England, $84,85,27 \mathrm{r}$; resignation in 1834,51 .

Story, Judge, remarks on leaving chair of Mass. House of Representatives, 2.

Stuart, Speaker pro tem., on recognition, 250 .

Substitutes for Speaker, 48-50, r4044.

Supreme Court, decision on Dingley Worsted act, 2r3.

Sutton, Speaker of House of Commons, 29, 271 n., 290 n.

Taylor, John W., elected Speaker in 1820 and in $1825,50,51,82,83$, 323; candidate for Speakership in 1821,83 ; character of Speakership, 82,83 .

Thanks, voted to Speaker at close 
of Congress, 45, 46; Speaker leaves chair, 134 .

Trevor, Sir J., Speaker of House of Commons, misuse of office, I33, I34; expulsion of, 124 .

Trumbull, Jonathan, election of Speaker in $1791,65,66$.

Tucker, Randolph, proposed amendment in 1881 to secure quorum, I89, 190.

Tully, Mr., Speaker of the House of Commons, 30.

Vance, Joseph, chairman of committee on Claims, 226.

Varnum, Joseph B., candidate for Speakership in 1805,69 ; elected Speaker in 1807 and $1809,50,69$; Gallatin's complaint of, 224.

Vice-President, 319.

Vinton, Sam. F., in election of 1847 , 90,91 .

Virginia Assembly, 14, 15.

Vote, refusal of members to (see Contents, Chap. VII.); Speaker announces, 136 .

Vote, Speaker's (see Contents, Chap. V., also 299, 300); how used by Clay, 72, 75; by Winthrop, 159; Winthrop on, 153; unnecessary votes cast by Clay, I52 ; by Boyd, 153 ; by Banks, 153; by Randall, 153, I54; to complete a two-thirds vote, 149, 154 ; negative vote on even division, 150, I5I ; Speaker a castingvote on questions of order, 167 , 168; Speaker gives casting-vote on own power, 236 ; motions to allow Speaker a vote in all cases, 152, 153; practice of New York Colonial Assembly, 17.

Washington, President of Constitutional Convention, 24; remarks from chair, 24, 25.

Weaver, filibustering of, 187 .

Wehster, Daniel, Clay appoints chairman of committee on Judiciary, 80, 226; influence over Speaker White, 224, 225.

Wentworth, John, tactics to secure floor for Benton, 257, 258 .

White, John, elected Speaker in $1841,34,90$; character of Speakership, 90 ; subserviency to Webster, 224, 225; accusation against, I30; decision relating to Speaker's vote, 150 ; admits right of appeal from recognition, 259 ; on recognition, 254,255 : on relation of Speaker to President, 322.

Winthrop, Robert C., Speaker of Mass. House of Representatives, 34 ; elected Speaker in 1847, $5 \mathrm{I}$, 90,91 ; qualifications for office, 92 ; popularity, $3^{6}$; character of Speakership, 92, 93; ruling on right of Speaker to make remarks from floor, 292 ; use of vote, I 59 ; candidate for Speakership in 1849 , 53-55, 93; Clay's advice to, 27 ; on Clay, 74 ; on Speaker's vote, 153; on Speaker's rank, 296, 297.

Wolsey, Cardinal, appears in House of Commons to demand subsidy, 5,6 . 


\section{EPOCHS OF AMERICAN HISTORY.}

MESSRS. LONGMANS, GREEN, \& CO. have the pleasure to state that they are now publishing a short series of books treating of the history of America, under the general title Epochs of AMERICAN History. The series is under the editorship of Dr. Albert Bushnell Hart, Assistant Professor of History in Harvard College, who has also prepared all the maps for the several volumes. Each volume contains about 300 pages, similar in size and style to the page of the volumes in Messrs. Longmans' series, 'Epochs of Modern History,' with full marginal analysis, working bibliographies, mans, and index. The volumes are issued separately, and each is complete in itself. The volumes now ready provide a continuous history of the United States from the foundation of the Colonies to the present time, suited to and intended for class use as well as for general reading and reference.

"* The volumes of this series already issued have been adopted for use as textbooks. in nearly all the leading Colleges and in many Normal Schools and other institutions. A prospectus, showing Contents and scope of each volume, specimene pages, etc., will be sent on application to the Publishers.

\section{THE COLONIES, 1492-1750.}

By Rruben Gold Thwaitrs, Secretary of the State Historical Society of Wisconsin ; author of " Historic Waterways," etc. With four colored maps. pp. xviii.-30r. Cloth. \$r.25.

CORNELL UNIVERSITY.

"I beg leave to acknowledge your courtesy in sending me a copy of the first volume in the series of 'Epochs of American History,' which I have read with great interest and satisfaction. I am pleased, as everyone must be, with the mechanical execution of the book, with the maps, and with the fresh and valuable 'Suggestions ' and 'References.' . . . The work itself appears to me to be quite remarkable for its comprehensiveness, and it presents a vast array of subjects in a way that is admirably fair, clear and orderly."-Professor Moses CoIT TYLER, Ithaca, N. Y.

\section{WILLIAMS COLLEGE.}

"It is just the book needed for college students, not too brief to be uninteresting, admirable in its plan, and well furnished with references to accessible authorities."-Professor RICHARD A. RICE, Williamstown, Mass.

\section{VASSAR COLLBGE.}

"Perhaps the best recommendation of 'Thwaites' American Colonies' is the fact that the day after it was received I ordered copies for class-room use. The book is admirable." -Professor LuCy M. SAlmoN, Poughkeepsie, N. Y.

"All that could be desired. This volume is more like a fair treatment of the whole subject of the colonies than any work of the sort yet produced."

$$
\text { -The Critic. }
$$

"The subject is virtnally 2 fresh one as approached by Mr. Thwaites. It is a pleasure to call especial attention to some most helpful bibliographical notes provided at the head of each chapter."-The Nation.

LONGMANS, GREEN, \& CO,, 91-93 Fifth Avenue, New York. 


\section{EPOCHS OF AMERICAN HISTURY.}

\section{FORMATION OF THE UNION, i750-1829.}

By Albert Bushneli. Hart, Ph.D. Assistant Professor of History in Harvard University, Member of the Massachusetts Historical Society, Author of "Introduction to the Study of Federal Government," "Epoch Maps," etc. With five colored maps. pp. xx,-278. Cloth. \$1.25.

The second volume of the EPOCHS of AMERICAN History aims to follow out the principles laid down for "THE COLONIBs," - the study of causes rather than of events, the development of the American nation out of scattered and inharmonious colonies. 'The throwing off of English control, the growth out of narrow political conditions, the struggle against foreign domination, and the extension of popular government, are all paris of the uninterrupted process of the Formation of the Union.

\section{LELAND STANFORD JR. UNIVERSTTY.}

" The large and sweeping treatment of the subject, which shows the true relations of the events preceding and following the revolution, to the revolution itself, is a real addition to the literature of the subject; while the bibliography prefixed to each chapter, adds incalculably to the value of the work."-MARY. SHELDON BARNes, Palo Alto, Cal.

"It is a careful and conscientious study of the period and its events, and should find a place among the text-books of our public schools."

-Boston Transcript.

" Professor Hart has compressed a vast deal of information into his volume, and makes many things most clear and striking. His maps, showing the territorial growth of the United States, are extremely interesting."

-Nezo York Times.

1. . The causes of the Revolution are clearly and cleverly condensed into a few pages. . . The maps in the work are singularly useful even to adults, There are five of these, which are alone worth the price of the volume."

- Magazine of American History.

- The formation period of our nation is treated with much care and with great precision. Each chapter is prefaced with copious references to authorities, which are valuable to the student who desires to pursue his reading more extensively. There are five valuable maps showing the growth of cur country by successive stages and repeated acquisition of territory."

$$
\text { -Boston Advertiser. }
$$

"Dr. Hart is not only a master of the art of condensation, . . hy is what is even of greater importance, an interpreter of history. He perceit:s the logic of historic events ; hence, in his condensation, he does not neglect proportion, and more than once he gives the student valuable clues to the solution of historical problems."-Atlantic Monthly.

-A valuable volume of a valuable series. The author has written with a full knowledge of his subject, and we have little to say except in praise."

-English Historical Reviezo. "

LONGMANS, GREEN. \& CO,, 9I-93 Fifth Averue, New Sork. 


\section{EPOCHS OF AMERICAN HISTORY.}

\section{DIVISION AND RE-UNION, 1829-1889.}

By Woodrow Wilson, Ph.D., LL.D., Professor of Jurisprudence in Princeton College ; Author of "Congressional Government," "The State-Elements of Historical and Practical Politics," etc., etc. With five colored Maps. 346 pages. Cloth, $\$ 1.25$.

"We regret that we have not space for more quotations from this uncom. monly strong, impartial, interesting book. Giving only enough facts to elucidate the matter discussed, it omits no important questions. It furnishes the reader clear-cut views of the right and the wrong of them all. It gives admirable pen-portraits of the great personages of the period with as much freedom from bias, and as much pains to be just, as if the author were delineating Pericles, or Alcibiades, Sulla, or Cæsar. Dr. Wilson has earned the gratitude of seekers after truth by his masterly production." $-N . C$. University Magasine.

"This admirable little volume is one of the few books which nearly meet our ideal of history. It is causal history in the truest sense, traeing the workings of latent intluences and far-reaching conditions of their outcome in striking fact, yet the whole current of events is kept in view, and the great personalities of the time, the nerve-centers of history, live intensely and in due proportion in these pages. We do not know the equal of this book for a brief and trustworthy, and, at the same time, a brilliantly written and sufficient history of these sixty years. We heartily commend it, not only for general reading, but as an admirable text-book."-Post.Graduate and Wooster Quarterly.

"Considered as a general history of the United States from 1829 to 1889, his book is marked by excellent sense of proportion, extensive knowledge, impartiality of judgment, unusual power of sumnarizing, and an acute political sense. Few writers can more vividly set forth the views of parties."

$$
\text { - Atlantic Monthly. }
$$

"Students of United States history may thank Mr. Wilson for an extremely clear and careful rendering of a period very difficult to handle . . . they will find themselves materially aided in easy comprehension of the political situation of the country by the excellent maps." $-N$. Y. Times.

" Professor Wilson writes in a clear and forcible style. . . . The bibliographical references at the liead of each chapter are both well selected and well arranged, and add greatly to the value of the work, which appears to be especially designed for use in instruction in colleges and preparatory schools." - Yale Review.

"It is written in a style admirably clear, vigorous, and attractive, a thorough grasp of the subject is shown, and the development of the theme is lucid and orderly, while the tone is judicial and fair, and the deductions sensible and dispassionate-so far as we can sec. . . . It would be difficult to construct a better manual of the subject than this, and it adds greatly to the value of this uscful series."-Harfford Courant.

". . . One of the most valuable historical works that has appeared in many years. The delicate period of our country's history, with which this work is largely taken up, is treated by the author with an impartiality that is almost unique."-Columbia Law Times.

LONGMANS, GREEN, \& C0., 91-93 Fifth Avenue, New York. 


\section{ENGLISH HISTORY FOR AMERICANS.}

By Thomas Wentworth Higginson, Author of "Young Folks' II tory of the United States," etc., and EDWARD Channing, Assistant Prufessor of History in Harvard University. With 77 Illustrations, 6 Colored Maps, Bibliography, a Chronological Table of Contents, and Index. 12mo. Pp. xxxii-334. Teachers' price, \$1.20.

The name " English History for Americans," which suggests the key-note of this book, is based on the simple fact that it is not the practice of American readers, old or young, to give to English history more than a limited portion of their hours of study. . . It seems clear that such readers will use their timc to the best advantage if they devote it mainly to those events in English annals which have had the most direct infuence on the history and institutions of their own land. . The authors of this book have therefore boldly ventured to modify in their narrative the accustomed scale of proportion; while it has been their wish, in the treatment of every detail, to accept the best result of modern English investigation, and especially to avoid all unfair or one-sided judgments. - . Extracts from Author's Preface.

DR. W. T. HARRIS, U. S. COMMISSIONER OF EDUCATION.

"I take great pleasure in acknowledging the receipt of the book, and believe it to be the best introduction to English history hitherto made for the use of schools. It is just what is needed in the school and in the family. It is the first history of England that I have seen which gives proper attention to socio$\log y$ and the evolution of political ideas, without neglecting what is picturesque and interesting to the popular taste. The device of placing the four historical maps at the beginning and end deserves special mention for its convenience. Allow me to congratulate you on the publication of so excellent a text-book"

\section{ROXBURY LATIN SCHOOL.}

$\because$. The most noticeable and commendable feature in the book seems to be its Unity. . . I felt the same reluctance to lay the volume down - . that one experiences in reading a great play or a well-constructed novel. Several things besides the unity conspire thus seductively to lead the reader on. The page is open and attractive, the chapters are short, the type is large and clear, the picturcs are woll chosen and significant, a surprising number of anecdotes told in a crisp and masterful manner throw valuable sidelights on the main narrative ; the philosophy of history is undeniably there. but sugar-coated, and the graceful style would do credit to a Macaulay. I shall immediately recommend it for use in our school."-DR. D. O. S. LOWELI.

\section{LAWRENCEVII,LE SCHOOL.}

"In answer to your note of February $23 \mathrm{~d}$ I beg to say that we have introduced your Higginson's English History into our graduating class and are much pleased with it. Therefore whatever endorsement I, as a member of the Committee of Ten, could give the book has already been given by my action in placing it in our classes."-James C. MACKeNzin, Lawrenceville, N. J.

ANN ARBOR HIGII SCHOOL.

"It seems to me the book will do for English history in this country what the 'Young Folks' History of the United States' has done for the history of our own country - and I consider this high praise."

-T. G. Pattengill, Ann Arbor, Mich.

\section{LONGMANS, GREEN, \& C0., 91-93 Fifth Arenue, New York}






\section{UNIIERSTTY OF TORONTO}

LIBRARY

Do not

remove

the card

from this

\section{Pocket.}

Acme Library Card Pocket Under Pat. "Ref. Index File." Mado by LIBRARY BUREAU 
